O. KORNEL GADACZ OFM Cap.

\title{
KATALOG RĘKOPISÓW BIBLIOTECZNYCH PROWINCJI KRAKOWSKIEJ ZAKONU OO. KAPUCYNÓW

$$
1600-1900
$$




\section{SPIS TRESCI}

Przedmowa . . . . . . . . . . . . . . . 5

Wstęp • . . . . . . . . . . . . . . . 6

Wykaz skrótów • . .

I. Rękopisy biblioteki klasztoru w Krakowie . . . . . . 11

II. Rękopisy biblioteki klasztoru w Krośnie . . . . . . 107

III. Rękopisy biblioteki klasztoru w Rozwadowie . . . . . 121

IV. Rękopisy biblioteki klasztoru w Sędziszowie . . . . 142

Wykazy pomocnicze . . . . . . . . . . . . . 169

Indeks przedmiotowy . . . . . . . . . . . . . 169

Indeks osób i miejscowości . . . . . . . . . . . . 170

Summarium . . . . . . . . . . . . . . . 177 


\section{PR Z E D M O WA}

Katalog niniejszy został opracowany w latach 1961-1962 i obejmuje wylącznie rękopisy biblioteczne klasztorów kapucyńskich prowincji krakowskiej bez względu na proweniencję. Wśród nich znajduje się kilka pozycji litograficznych. Umieszczono je wśród rękopisów dlatego, że niejedna z nich po zniszczeniach wojennych może posiadać wartość unikalną.

Rękopisy te, z wyjątkiem nielicznych jak np. nr 14:1 i 143, nie byly w ogóle wykorzystane przez specjalistów; tym bardziej nikt nie podjął się opracowania katalogu wszystkich rękopisów. W latach 1930-1934 o. Zenon Gorlicki przeprowadził inwentaryzację rękopisów dla kapucyńskiego „Collegium S. Laurentii Brundusini“"w Asyżu. Poprzestal jednak na bardzo ogólnym opisie ograniczając się do podania tytułu, wymiarów i ilości kart. Przy okazji posygnował manuskrypty cyframi alfabetu rzymskiego. Sygnatury te zostały uwzględnione $\mathrm{w}$ obecnym katalogu. Okazało się przecież, że inwentaryzacja ta nie objęła wszystkich manuskryptów. W biblictekach kapucyńskich bowiem rękopisy włączano od dawna do właściwych działów rzeczowych całości zbiorów, nie wyodrębniając ich $\mathrm{w}$ osobną grupę. W r. 1949, przy katalogowaniu biblioteki klasztoru krakowskiego, autor celowo wydzielił manuskrypty spośród druków z myślą o opracowaniu w przyszłości katalogu rękopisów. Po jego odejściu (opracował 18.000 pozycji) następca na powrót wcielił wszystkie rękopisy pod numerus currens biblioteki, nie troszcząc się nawet o ogólny opis manuskryptów. Rękopisy te abecnie zostały ponownie wydzielone z druków i wraz $z$ księgami pisanymi innych klasztorów poddane $\mathrm{w}$ okresie wakacyjnym 1961 r. zasadniczej konserwacji. Z kolei przewrieziono je do Tenczyna i tam przystąpiono do opracowania katalogu. Warunki do pracy naukowej stworzył tu bezinteresownie o. Medard Parysz; w Krakowie zaś istniały nie tylko trudności lokalowe.

Foliację manuskryptów pod kierunkiem autora przeprowadzili w sierpniu 1961 r. klerycy: Bohdan Kruk i Eligiusz Kądziela.

Oprawy opisał dr Robert Jahoda Żółtowski.

Autorów rękopisów jezuickich podał ks. dr Bronisław Natoński T. J., który równocześnie dostarczył bogatej dokumentacji, zwłaszeza archiwalnej, do biogramów zachodzących w pracy członków tegoż zakonu.

Prace podjęto za namową ks. dr Stanisława Librowskiego, który też, wspólnie z p. dr Witoldem Nowodworskim, włożył wiele wysiłku w ostateczną jej redakcję.

Wszystkim wyżej wymienionym Współpracownikom składam najserdeczniejsze podziękowanie. 
1. Proweniencja rękopisów

Biblioteki kapucyńskie prowincji krakowskiej posiadają $w$ sumie 289 rękopisów bibliotecznych $\mathrm{z}$ lat 1600-1900. Wśród ogółu manuskryptów większoość stanowią rękopisy szkolne. Reprezentują one prawie wszystkie ważniejsze ośrodki naukowe krajowe i zagraniczne, tak na poziomie średnim jak i akadlemickim. $Z$ natury rzeczy najwięcej jest rękopisów ze szkół kapucynów polskich. Na uwagę zasługują również rękopisy ze szkół kapucynów czeskich, względnie śląskich.

Poważny procent stanowią rękopisy $z$ kolegiów jezuickich i pijarskich z olbszaru Polski przedrozbiorowej. Znajdują się tu również rękopisy, które wyszły z Akademii Krakowskiej, Wileńskiej i Lwowskiej. Z zagranicznych można wymienić pozycje z Collegium Romanum, Seminarium Arcybiskupiego w Neapolu i Uniwersytetu w Würzburgu.

Rękopisy ite różnymi drogami docierały do tutejszych zibiorów bibliatecznych. Najwięcej manuskryptów odziedziczyły biblioteki po zmarłych zalkonnikach i lektorach zakonnych, którzy przed wstąpieniem do zakonu niejednokrotnie kończyli kolegia jezuickie lub pijarskie. Po kasacie jezuitów, niektórzy członkowie wspomnianego zakonu wstępowali do kapucynów, pozostawiając po sobje skrypty szkolne. Pewna liczba rękopisów pochodzi z legatów zmarłych dostojnilków kościelnych jak np. bpa krakowskiego Kazimierza Łubieńskiego, rektorów Akademii Krakowskiej, ks. prof. Jana Michalskiego i ks. prof. Antoniego Krząnowskiego, fundatorów oraz duchownych dobrodziejów. Wreszcie nie można pominąć także rękopisów zakupionych przez przełożonych zakonnych i lektorów dla wewnętrznego użytku.

Oczywriście wykazana wyżej liczba rękopisów nie jest kompletna. Znaczna ich część została przekazana przez komisje rządowe do Biblioteki Uniwersyteckiej we Lwowie w czasie kasaty klasztorów w Mariampolu w r. 1783 , w Olesku i Lwowie w r. 1785 oraz w Bliznem w r. 1788. Nie wróciły one w całości do bibliotek klasztornych mimo przywrócenia klasztoru w Olesku w r. 1788.

Inną bolesną stratę poniosły biblioteki w czasie drugiej wojny świátowej. Wtedy to przepadła całkowicie biblioteka klasztoru w Kutkorzu (1944) pozostawiona na miejscu przez o. Wojciecha Strzemeckiego, ostatniego przełożonego i proboszcza tejże parafii. Na szcześście zachował się spis jej rękopisów sporządzony w r. 1933 przez o. Zenona Gorlickiego ${ }^{1}$.

1 o. Z. Gorlick1: Notationes bibliograph1cae. Bibl. Kap. w Krośnie. Rkps APK k. $143 \mathrm{~V}, 144$. 
Wykaz ten, zapewne niepełny, obejmuje następujące pozycje:

1. Bez sygn. $18 \times 16 \mathrm{~cm} . \mathrm{Knlb} .37$. „O sakramencie pokuty. O. Józef Krzysikiewıcz, Olesko 1831".

2. Bez sygn. $1759.18 \times 16 \mathrm{~cm} . K .37$

„Summa elementorum dialecticae iuxta verum sensum et mentem Subtills Marianıque Doctoris Joannis Duns Scotı exposita... Ad aedes Divı Antonii Paduani explanata. A. D. 1759 mense novembris".

3. Sygn. 21 G. $18 \times 16 \mathrm{~cm}$. K. 118 .

„Philosophiae aristotelico - scotisticae pars I, videlicet logica universa luxta verum sensum et mentem Subtilis Marıanique Doctoris Joannis Duns Scoti explanata".

4. Sygn. 104 teol. $1750.19 \times 16 \mathrm{~cm}$. K. 227. "Arcana s. theologiae universae iuxta mentem Subtilis Marianique Doctoris Joannis Duns Scoti methodo scholastica elucidata".

5. Sygn. 43 c. (278). $14 \times 9$ cm. K. 300 . "Traktat o sakramencie s. pokuty".

6. Sygn. $15 \mathrm{~K}, 1761$ (?). $19 \times 16 \mathrm{~cm} . \mathrm{K}, 151$. „Philosophıae aristotelico - scotisticae pars II, vıdelicet physica universa iuxta verum sensum et mentem Subtilis Marianique Doctoris Joannis Duns Scotı explanata. Ad sacras vero aedes ss. Petri et Pauli ap. Lublini explicata".

7. $1761 . K .15$. „Philosophiae arıstotelico - scotisticae pars III, videlicet metaphysica universa iuxta verum sensum et mentem Subtilis Marianique Doctoris Joannis Duns Scotı exposita. Lublini explicata anno 1761".

8. Sygn. 444 A. $16 \times 10 \mathrm{~cm} . K .38,39$. „Prolegomena metaphysicae. Compendium physicae".

9. Sygn. 445 P. 1750 (?). $16 \times 10 \mathrm{~cm}$. K. 50. "Logica".

10. Sygn. $21 \mathrm{~J} .21 \times 15 \mathrm{~cm}$. K. 207. "Teologia pastoralna".

11. Sygn. 4 A. 1787. $18 \times 11 \mathrm{~cm}$. K. 111.

"Exercitia spiritualıa pro utilitate spirıtuali eadem peragentium tum religiosorum nostri ordinis, tum aliorum culuscumque status fidelium conscripta ac per 10 dies disposita. Anno 1787 per A. V. P. Thadaeum Capuc".

12. Sygn. 5 A. $18 \times 11 \mathrm{~cm} . \mathrm{S} .384$.

"Conciones latmae per totum annum".

Straty pozostałych klasztorów z braku odpowiednich katalogów nie dadzą się wykazać.

$\mathrm{Z}$ ocalałych bibliotek najwięcej rękopisów posiada obecnie biblioteka klasztoru krakowskiego. Zbiór jej w liczbie 170 rękopisów pochodzi $z$ darów, legatów i spuścizn po zmarłych zakonnikach. Znailazł on pomieszczenie w specjalnym budynku bibliatecznym dobudowanym do klasztoru w r. 1720.

W ciągu wieku biblioteka krakowska wabogaciła się resztkami rękopisów $\mathrm{z}$ innych bibliotek kapucyńskich, zwłaszcza $\mathrm{z}$ klasztorów ska- 
sowanych lub opuszczonych jak np. z Oleska, Mariampola lub Winnicy. Nawet w naszych czasach udało się nabyć rękopis z dawnej biblioteki kapucyńskiej w Ostrogu. Praktyka wykazuje, że liczba rękopisów kapucyńskich może jeszcze wzrosnąć ${ }^{2}$.

Biblioteka klasztoru w Sędziszowie ma 52 rękopisy. Liczba ta jest niepełna choćby z tego względu, że w okresie józefinizmu klasztor miał ulec kasacie. Dlatego bibliotekę zasobną w stare druki przewieziono do cyrkułu w Rzeszowie i tam porzucono. Część ksiiażek urzędnicy rozebrali między siebie, a znikomą cząstkę zwrócono klasztorowi. Wtedy zaginęly z pewnością i rękopisy a wśród nich pierwisza kronilka klaszitoru.

Klaszitior w Rozwadlowie był jedynym konwentem wolnym od groźby kasaty, ponieważ kościół klaszitorny służył jednocześnie parafii, a zalkonnicy pracowali w duszpasterstwie w charakterze wikarych. Biblioteka klasztoru przechowała zaledwie 45 rękopisów i kilka m. b. kazań kapucyńskich z XVIII-XX w. Kazania te przepadły w ostatnich latach. Tu równiez przechowało się szczątkowe archiwum rodziny kisiążąt Lubomirskich $z_{1}$ Charzewic. Zostało ono prziejęte w r. 1961 przez PPRN w Tarnobrrzegu.

Najmmiej rękopisów, bo tylko 22, posiada biblioteka klasztoru w Krośnie. I tu groźba kasaly w okresie józefinizmu ciążyła nad klasztorem i nie sprzyjała zachowaniu manuskryptów, których pewiną część otrzymał klasztor $\mathrm{w}$ darze prawdiopodabnie po skasowanych jezuitach w Krośnie.

2. Metoda opracowania

Przy opisywaniu rękopisów oparto się $w$ zasiadzie na instrulkcji $W y$ tyczne opracowania rękopisów $w$ bibliotekach polskich (Wrocław 1955). Przepisy te w odniesieniu do rękopisów nowych przewidują raczej skrócony i ogólny opis, jakkolwiek pozostawiają swobodę $w$ indiywidualnym podejściu do zagadnienia katalogowania tychi̇e. $Z$ drugiej znowu strony Wskazania dla rejestrujacych rękopisy przedrozbiorowe (do r. 1750), rozesłane w r. 1960 przez ośrodek ABMK przy KUL polecają dokładne i szczegółowe opracowainie manuskryptów. Powyższe instrukcje slkłoniły autora do zastosowania metody, która - jego zdaniem - powinna

2 W Bibliotece $1 \mathrm{~m}$. Ossolińskıch we Wrocławıu znajduje sıę pıę́ rękopisów (sygn. 10, 167, 242, 1427 i 4792) zabranych ok. 1795 r. przez Tadeusza Czackiego z klasztorów w Krakowie 1 Olesku. Biblioteka Im. Gwalberta Pawlikowskiego we Lwowie posiadała jeden rekopis kapucyńskı. W Bibliotece Jagıellońskıej przechowuje sie dzıesıęc rẹkopısów $z$ biblioteki klasztoru w Krakowie. - Por. J. Pa chońs k 1 : Drukarze, ksıegarze 1 bibliofile krakowscy 1750-1815. Kraków $1962 \mathrm{~s}$. 231, 235: W K ętr z y ńs k 1 : Katalog rękopısów Bibliotekı Zakładu Narodowego $\mathrm{im}$. Ossolińskich. T. 1. Lwów 1881 s. 4-5, 301-303. T. 3. Lwów 1898 s. 581-584; Inwentarz rękopisów Biblioteikı Zakładu Narodowego im. Ossolińskıch we Wroclawıu. Oprac. pod red. J. Turskle J. T. 1. Wrockaw 1948 s. 406; M. G ę barow c z: Katalog rękopısów Bibliotekı Im. Gwalberta Pawlikowskıego. L,wów 1929 s. 17-18; W1. W is lock1: Katalog rękopısów Bibliotekı Unıwersytetu Jagıellońskıego. Kraków 1877-1881 nr 4160-4169. 
doprowadzić do zlakreślonego z góry celu tj. do takiego opracowania przekazu rękłopiśmiennego, ażeby mógł on wszystko o sobie powiedzieć tak pod względem formy jak i treści. W wielu wypadkach zaniechano dokładnego wykazu treści tych rękopisów, które dla teologa są zrozumiałe i jasne. Rękopisy $\mathrm{z}$ drugiej połowy XIX w. potraktowano, ze zrozumiałych względów, inaczej i zastosowano opis skrócony.

$\mathrm{Na}$ pierwszym miejscu po sygnaturze - zgadnie $z$ instrukcja umieszczono opis ogólny. W opisie tym $\mathrm{m}$. in. podano foliację rękopisów, na którą pornołuje się autor $\mathrm{w}$ katalogu $\mathrm{z}$ wyjątkiem kilku rękopisów historycznych, wykorzystanych przez historyków. Paginacja oryginalna rękopisów została wykazana $\mathrm{w}$ szczegółowym opisie.

Tytuły oryginalne ujęto $\mathrm{w}$ cudzysłów. Zwroty sakralne wykropkowano. Pisownię lacińską, interpunkcję i stosowanie dużych liter zmodernizowano.

Po tytule umieszczono incipity i eksplicity w ilości około pięciu słów, $\mathrm{z}$ dokładnym podaniem karty lub strony. Sa one niezbędne przy identyfikacji rękopisu.

W szczegółowym opisie kodeksu podanю, w miarę potrzeby, treść rękopisu względnie wykaz traktatów, szkołę, z której kodeks wyszedl, professorów i lektorów oraz skryptorów. Nazwiska te pominięto w wypadku, gdy w sposób jasny i zrozumiały zostały podanie w tytułach rękopisów.

Zaznaozyć należy, że prawie wszystikie rękopisy $\mathrm{z}$ XVII, XVIII i pierwsziej pol. XIX w. sa wykonane z prążkowanego bialego papieru czerpanego; dlatego w opisach dane te opuszczono. Zarejestrowano jednak wszystkie odichylenia od tej reguły. Omawiane kodeksy zapisane są kursywą XVII-XIX-wieczną; w następstwile tego wyjątkowo tylko podano szczególny charalkter lub dukt pisma. Zwrócono uwagę na reklamanty, paginację oryginalną rękopisu i karty nieza pisane. Starano się dokładnie podać wszelkie rysunki, ryciny i floratury. W cudzysłowie poidano inskrypcje, mówiące o szkole, profesorach, lektorach, skryptorach a czasami nawet krótkie wzmianki o treści historycznej lub obyczajowej. Zaakcentowano sentencje, zwłaszcza polskie, tak w tekście jak i na wyklejkach. W tej rubryce zasygnalizowano napisy $w$ innych językach. W wypadlku występowania dłuższych wierszy łacińskich, ograniczono się do zanotowania ich obecności. Zwrócono uwage na wszelkie daty. W kodeksach szkkolnych podano występujące wykazy słuchaczy. Poddano też glosy marginalne i interlinearne.

Policzono skłladki i wykazano kustosze.

Filigrany $z$ omawianego okresu nie sa jeszcze opracowane, dlatego $z$ koniecznaści zastosowano tu metodę opisowa. 
W opisie opraw opuszczono zwrot: ,wyklejka, papier czerpany prążkowany“, ponieważ wyklejki są najczęściej z tego samego papieru co i blok ręlkopisu.

Dolkładnie zajęto się ustaleniem proweniencji i dawnych sygnatur dla każdej pozycji. Przecholdzenie rękopisu z rạk do rąk może wiele powiedzieć - jego przeszłości, znaczeniu, użyteczności i celu, który spełnił, zanim spoczął na półkach bibliotecznych.

W końcu rękopisy poszczególnych klasztorów potraktowano oddzielnie, ażeby nile zrywać łączności z macierzystym zbiorem. Wszystkie manuskrypty uszeregowano działami. W wypadku istnienia w jednym kodeksie kilku różnych treściowo pozycji, kodeks umieszczono pod hasłem działowym pierwszej części. Indieks przedmiotowy wskaże dokładnie jednolite pozycje. W obrębie poszzczególnych działów zastosowano układ chronologiczny. Całą kolekcję rękopiśmienną ułożono według następującego schematu:

1. Teologia dogmatyczna

2. Teologia moralna

3. Teologia pastoralna
a. Homiletyka
b. Katechetyka
c. Liturgika
a. Modllitewnilki
ß. Spiewniki

4. Teologia ascetyczna i mistyczna

5. Biblistyka

6. Historia Kościoła

7. Prawo kanoniczne

8. Filozofia scholastyczna

9. Historia powszechna

10. Prawo świeckie

11. Dydlaktyka. Pedagogika

12. Językoznawstwo

a. Retoryka i poetyka

13. Litieratura piękna

14. Medycyma

W przypisach poidano ustalone dame bilograficzne o profesorach, lektorach i skryptorach.

Zasady, wedkug których opracowano ,indeks osób i miejscowrości“ wyjaśniono na początku indeksu.

Być może, iż oddlawany do druku katalog rękopisów kapucyńskich wyda się niejednemu zbyt obszerny, atoli przez to zyskuje on na jasności 


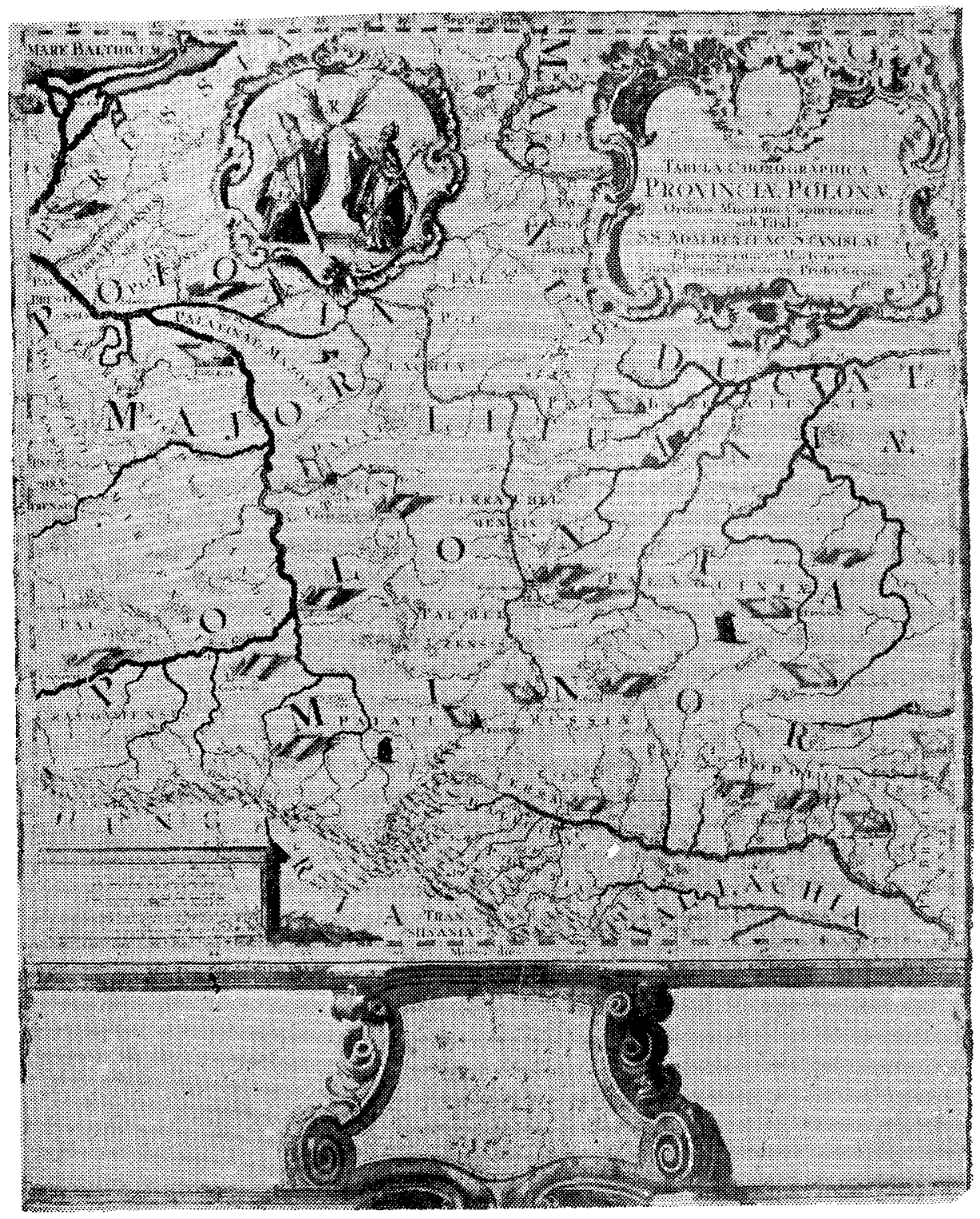

Mapa prowincji polskiej zakonu OO. Kapucynów, 
i pewniej spełni swój cel, którym jest dostarczenie nauce wyczerpującej informacji o źródłach do zbadianila stanu szkolnictwa kościelnego w omawianym okresie czasu.

WYKAZ SKROTOW

AKK - Archiwum Klasztoru OO. Kapucynów w Krakowie

APK - Archiwum Prowincji Krakowskıej OO. Kapucynów

ArSI - Archiwum Romanum Societatis Iesu

$\mathrm{K}$ - Biblioteka Klasztoru OO. Kapucynów w Krośnie

R - Biblioteka Klasztoru OO. Kapucynów w Rozwadowie

S - Biblioteka Klasztoru OO. Kapucynów w Sędziszowie.

\section{RĘKOPISY BIBLIOTEKI KLASZTORU W KRAKOWIE}

\section{TEOLOGIA DOGMATYCZNA}

1. Eac, 1673. $23 \times 16 \mathrm{~cm} . K .319$. Opr. perg. wsp.

1. k. $1-179 \mathrm{v}$. „De gratia divina auxiliante et sanctificante. Disputationes scholasticae ad 1mam 2dae S. Thomae Doctoris Angelici“.

Inc.: $\mathbb{k}$. 1: „Status gratiae sufficientis controversionem aperitur X Et haec de gratia sufficiunt". k. $177 \mathrm{v}$.

2. k. 181-315. "Tractatus de sacramentis in genere et eucharistia".

Inc.: k. 181: „Ad 3am partem S. Thomae a q. 53 usque ad X Et haec de sacramentis et de eucharistia." k. 315.

Szkoła: Collegium Romanum S. J. w Rzymie. Profesor: o. Mikołaj Martinez ${ }^{1}$ T. J. Skryptor: ks. Kazımierz Łubieński ${ }^{2}$, późnıejszy biskup krakowski.

Reklamanty występują rzadko. Oryginalna paginacja rękopisu: 352, nlb. 7; 270, nlb. 9. Spis treści na k. 178-179v i 317-318v. Na początkowych $10 \mathrm{k}$. kilka glos marginalnych. Wklejka k. 151a. Inskrypcje: k. 1: „Anno 1763 die 5 nov. Romae". Podobne w treści na k. 178 i 317.

1 Ur. w Sewilli 20 I 1612, do zak. wstąpik 1629, zm. 30 IX 1676 w Ecija. Prof. teologii scholastycznej $w$ Colleglum Romanum w 1. 1659-1675. - A. de B a c k e r Bibliothèque de la Compagnie de Jésus. Nouv. éd. par C. So m m e rvog e l. T. 1-11. Bruxelles 1890-1932 Corrections et additions par. E. M. $R \backslash \mathrm{V} 1$ è $\mathrm{r}$ e $\mathrm{T}$ julouse 1911-1930. T. 5 S. 634 (skrót: Backer-Sommervogel); Riccardo G. Villos 1 a d a S. J.: Storla del Collęilo Romano (1551-1773). Romae 1954 (wedlug incieksu).

2 Ur. 1642, zm. 1719. Bp krakowskim od r. 1711. - Encyklopeaia kościelna. Wyd. ks. M. Nc wo dworski. T. 1-32. T. 33 red. ks. S. B iskup ski. Warszawa (T. 32 Płock, t. 33 Włocławek) 1873-1933 (skrót: Enc. Now.). T. 12 s. 589-590; Podręczna Encyklopedia koścıelna. Wyd. ks. Z. C h e ł m i c k 1, T. 1-44. Warszawa 1004-1914. Suplement 1. Warszawa 1918 (skrót: Enc. Chełm..). T. $25 / 26$ s. 108-109; Encyklopedia powszechna S. O r gelbranda. T. 1-28. Warszawa 1859-1868. Suplement 1879 (skrót: Enc. Orgelbr.). T. 17 s. 663; Bp L. E e to w s k 1: Katalog biskupów, prałatow 1 kanoników krakowskich. T. 1-4. Kraków 1852-1853, T. 2 s. 227230; Ks. K. NI es 1 e ck1: Herbarz polski. Powiększony dodatkami i wyd. przez J. B o b r o w Ic z a. T. 1-10. Lipsk 1839-1846. T. 6 s. 282-283; A. J o c h e r: Obraz bibliograficzno-historyczny literatury I nauk w Polsce od wprowadzenıa do niej druku po rok 1830 włącznıe (skrót: Jocher). 
Składkı: 24. 2 i 14 po 2 k. Biniony 13 i 24 bez 1 k. Ternion 23. Septentriony 1, 7. Pozostale okterniony.

Filigrany: goląbek na postumenciku w kole, ponad kolem litera $G$ lub $D$, k. 1,6 .

Oprawa w tekturę szarą, półtwardą. Grzbıet i okładki obciągnıęte pergaminem. Grzbiet wzmocniony papierem czerpanym, zamalowany późnıej farbą olejną popielatą, na którym czarnym kolorem wymalowano trzy kartusze barokowe, gómy z tytulem: „Disput. de gratia divina", środkowy z częścıą sygn. D (rubryk.) 1 dolny $z$ miejscem na sygnaturę liczbową. Kapıtałka szyta jedwabna, białoniebieska.

Proweniencja: 1. Kazimierz Łubieński, bp krakowski.

2. „Ex lib. a Cels. Principe Casimiro Eubiensiki Ep. Crac. donatis et applicatis Bibliathecae Cracoviensi PP. Capucinorum", k. 1. Biblioteka OO. Kapucynów. IKraków. Pieczątka okrągła na odwrocie frontowej wyklejki, na k. $177 \mathrm{v}$ i 319v. Sygn.: 9 D-31; Nr LXXXVI (o. Z. G.) na frontowej wyklejce.

\section{Eac. 1673-1674. $22.5 \times 15.5 \mathrm{~cm} . K .175$. Opr. perg. wsp.}

„De augustissimo Dominicae incarnationis misterio. Controversiae quinque scholasticae ad 3um Mag. Sen. Librum a dist. 1 et 3 p. Diji] T[homaie] q. 1. (Tytuł naglówkowy, k. 1.).

Inc.: k. 1: „Gratia operi post scholasticam iuris $\mathrm{X}$ addaucta, nondum includat in ipso meritio". k. 175.

Szkoła: Collegium Romanum S. J. w Rzymie. Profesorowie: o. Mikołaj Martınez 1 o. Sylwester Maurus ${ }^{3}$ T. J. Skryptor: ks. Kazımierz Eubieński.

$\mathrm{Na}$ marginesach numery paragrafów poszczególnych zagadnień. Karty nıezapisane: $164 \mathrm{v}, 165 \mathrm{r}$. Kodeks wykonany z pıęknego papıeru włoskiego, prążkowanego.

Składk1: 12. Binion 3. Seksternion 11. Septentrion 2. Pozostale okterniony ale 12 bez 2 wydartych $\mathrm{k}$.

Filigrany: gołąbek w kole z literą A, k. 5, 15. Gołąbek na postumenciku w kole, ponad kołem litera F lub $\mathrm{R}, \mathrm{k} .6,9,42,163$.

Oprawa w tekturę szmacianą szarą, obciągnięta w całości pergamınem. $\mathrm{Na}$ grzbiecie resztkı malowania farbą popielatą. Slady trzech kartuszy, w górnym tytuł: "Contr. de incarmationis misterio", w środkowym część sygnatury: D (rubr.), w dolnym miejsce na sygnaturę liczbową. Kapitałka szyta ręcznie jedwabıem dwukolorowym na rzemyku perg., przeciągniętym przez zawiasy okładk1.

Proweniencja: 1. Kazimierz Eubieński, bp krakowski.

2. „Ex i ibris Casim. Eubieński Ep. Crac. donatis et applicatis Bibl. Cracoviensi PP. Capucinorum“, k. 1. Biblioteka OO. Kapucynów. Kraków. Pieczątka okragła na odwrocie k. ochr. i k. 175v. Sygn.: G-7; $\mathrm{Nr}$ XXIX (o. Z. G.) na frontowej wyklejce.

T. 2. Wilno $1840 \mathrm{nr}$ 7534; Wł. W 1 sło $\mathrm{ckl}_{1}$ : Katalog rękopisów Bibliotekı Unıwersytetu Jagiellońskıego. Kraków 1877-1881 nr 3, 3755, 3952.

3 Ur. w Spoleto 31 XII 1619, do zak. wstąpil 1636, zm. 13 I $1687 \mathrm{w}$ Rzymie. Prof. Collegium Romanum w l. 1667-1682. Glośniejszy filozof (wydawca dzıel Arystotelesa) niż teolog. B a c k e r-S o m m e r vogel V 765-769; V 11 los l a d a, Jw. (według indeksu); H. H u r ter: Nomenclator litterarius theologiae catholicae, theologos exhibens. T. 1-5. Innsbruck 1903-1913 (skrót: Hurter). T. 4 s. 344. 
3. Eac. 1674. $22.5 \times 15.5 \mathrm{~cm}$. K. 294. Opr. perg. $w s p$.

1. k. 2-147v. „De virtutibus theolagicis, fide, spe et charitate. Disputationes scholasticae ad secundam secundae D[ivi] Tho[mae] $D[$ octo]ris Angelici". (Tyituł nagłówkowy).

Inc.: k. 2: "Quid sit fides divina? In explicanda $\mathrm{X}$ Charitatem et spem colet perpetue". k. $146 \mathrm{v}$.

2. k. 152-293. „De sacramento et virtute paenitentiae“.

Inc: k. 152: „Ad tertiam partem S. Thomare a q. 84 usque ad finem X Et haec de paenitentia sufficiunt". k. 289.

Szkola: Collegium Romanum S. J. w Rzymie. Profesorowie: o. Mikołaj Martinez $i$ o. Sylwester Maurus T. J. Skryptor: ks. Kazimierz Eubieński.

Reklamanty występują rzadko. Spıs treści: k. 147-148v, 290-292v. Oryginalna paginacja kodeksu: nlb. 2, 308, nlb. 10; 275, nlb. 14. Karty niezapisane: 1, 149-151, 293v, 294. Karty wydarte 4 między k. 146 a 147. Inskrypcje: k. 14v: „Lucubrationes Adm. Rndi Patrıs Martınez ann1 1674 in Collegio Romano datae. Hic celeberrimus theologus et summae speculationis vir sexdecim annorum Romae in. lucubrationibus theologicis labore illustris, a quo requiem anno superius notato, in Domino autem 1676;“ k. 293: „Haec doctrina ad mentem D[ivi] Thomae in Collegio Romano data ab Adm. Rdo Patre Mauro anno 1674".

Składki: 25. Biniony 13, 25. Septentriony 10, 18. Okternion 24. Pozostałe seksterniony.

Filigrany: gołąbek na postumenciku w kole, ponad kolem litera G lub D, k. i50. Na frontowej wyklejce goląbek $\mathrm{w}$ kole.

Oprawa w tekturę szarą póltwardą. Grzbıet i okładki obciągnięte pergaminem. Grzbiet wzmocniony papıerem czerpanym, zamalowany później farbą olejną, popielatą, na którym czarną farbą wymalowano trzy kartusze barokowe, górny $\mathrm{z}$ tytułem: „Disput. de virtutibus theolog.“, środkowy $\mathrm{z}$ częśc1ową sygn. $\mathrm{D}$ (rubryk.) i dolny $\mathrm{z}$ miejscem na sygn. liczbową. Sžcie na 3 sznurki. Kapitałka szyta brałoniebreska.

Proweniencja: 1. Kazimierz Eubieński, bp krakowsiki.

2. „Ex libris a Cels. Principe Casmiro Eubieński donatis et applicatis Bibliothecae "Cracoviensi PP. Capucinorum". Napis w dolnym marginesie k. 2. Biblioteka OO. Kapucynów. Kraków. Pieczątka okrągla na k. 1v, 148v, 293. Sygn.: $10 \mathrm{G}-10$; XXVIII (o. Z. G.) na frontowej wyklejce.

4. Eac. 1679-1680. $19.5 \times 15 \mathrm{~cm}$. K. 655. Opr. perg. wsp.

[Commentarium in Quatuor Libros Sententiarum].

Inc.: $\mathrm{k}$. 3: „Licet q1.ae in terris fiunt magna $\mathrm{X}$ ommiumque sanctorum dicta sint". k. 646.

Szkoła nieznana.

Treść: In Librum Prımum Sententiarum, k. 3-115; In Librum 2dum Sententiarum, k. 116-200; In Librum Tertium Sententiarum, k. 202-348; In Librum Quartum Sententiarum, k. 351-646.

Kodeks napısany jedną ręką wyraźnym pısmem. Reklamanty i podkreślenia $w$ tekście. Oryginalna paginację posiada od k. 351, która obejmuje strony 1-594, nlb. 18. Karty niezapısane: 1, 2, 200v, 201, 299, 337, 348v, $349,350,649 v, 651 v-655$. Spis treścl w dwóch kolunnach na k. 647-651. 
Inskrypcje: k. 115v: „Die 23 februarii. A. D. 1679“; k. 200: „Anno Dni 1680 die 31 maii“; k. 336v: "Die 20 maii. A. D. 1680".

Składki: $59.10 \mathrm{ma} 2 \mathrm{k}$. Ternion $5 \mathrm{bez} 1 \mathrm{k}$. Kwaterniony 28, 29, 30 bez $1 \mathrm{k}$. Kwinterniony 15, 16, 41, 42, 44, 57. Septentriony $2,3,14$ bez $1 \mathrm{k}$, $22,23,24,43,45,48,49$. Oktermiony 6,8 . Pozostałe seksterniony lecz 58 bez $4 \mathrm{k}$.

Filigrany: serduszko $\mathrm{z}$ krzyżem $\mathrm{w}$ otoku, na wyklejce frontowej. Zdobnik na wyklejce tylnej. Tarcza herbowa $z$ gryfem, $k$. 1, 2. Dwie postac1, w środku roślina, u dołu napis: Allmod papier, $k$. 349, 652. Tarcza herbowa z koroną pięciopalkową, k. 655 .

Oprawa w szarą tekturę półtwardą, obcıągniętą w pergamin. Grzbiet z osobnych części pergaminu, barwiony na czerwono. Grzbiet zamalowany farbą olejną, popielata $\mathrm{z}$ trzema kartuszami barokowymi ciemno zielonymi. W górnym tytul: „In 4 Libr. Sententiarum“. W środkowym sygn. D (rubryk)., w dolnym miejsce na sygnaturę liczbową. Slady dwóch par rzemyków do wiązanı. Kapitałka białoczerwona. Brzegi czerwone.

Proweniencja: Biblioteka OO. Kapucynów. Kraków; pieczątkaj okrągla na k. 2v. i 651 v. Sygn.: $9 \mathrm{D}-6$; Nr LXV (o. Z. G.) na frontowej wyklejce.

5. Eac. 1714-1715. $27 \times 19.5 \mathrm{~cm}$. K. 274. Opr. perg. wsp.

1. k. 1-129. "Tractatus de Trinitate".

Inc.: k. 2: "1mum. Nihil est quod divinae substantiae excellentiam $\mathrm{X}$ Haec pro interim de Sanctissima Trinitate...". k. 128v.

2. k. 131-191v. "Tractatus de Christo“.

Inc.: k. 132: „Quoniam haec et vita aeterna ad quam $\mathrm{X}$ sed etiam angelorum doctor et magister sit Christus". k. 191.

3. k. 193-274. "Tractatus de gratia Dei“.

Inc.: k. 194: „Non unum catholicae fidei caput $\mathrm{X}$ sed intelligere nequaquam possunt. S. Greg. lib. 1 Moralium, cap. 32“. k. 273.

Szkoła: Seminarium Arcybiskupie w Neapolu. Profescr: prawdopodobnie Januarıus Fortunatus ${ }^{4}$. Skryptor: ks. Antoni Krząnowski ${ }^{5}$, późnıejszy prepozyt kościoła św. Floriana na Kleparzu w Krakowie.

Reklamanty. Paginacja oryginalna: nlb. 2, 254; nlb. 6, 119, nlb. 3; nlb. 2, 160, nlb. 2. Karty niezapisane: 1v, 129v, 130, 131v, 192, 193v, 274v. Spis treści na k. 129, 191v i 274. Na k. tyt., 131 i 193 ponad tytułem umieszczony ozdobny krzyżyk. Na górnym marginesie każdej strony krzyżyk. Glosy margınalne na k. 98v. Na końcu rękopısu 4 k. wycıęte.

- Gennaro Fortunato, zm. 1751 r. Pozostawił w rękopısıe traktat ,De Trınitate“

- Na probostwo św. Florıana instytuowany 1758, prof. Akad. Krak., prokurator kanonızacji sw. Jana Kantego w Rzymie w r. 1767, rektor Akad. Krak. 1774-1775, zm. 1795. - Zblór zwyczajnych modlitw i pieśni bractwa Ubóstwa Chrystusowego przy kościele paráfialnym sw. Florıana na Kleparzu, z dodatkıem waznıejszych zapısków z kroniki tegoz kościola. Kraków $1862 \mathrm{~s} .47$; A. K a r b ow l a k: O rektorach Uniwersytetu Kazımıerzowiskıgo 1 Jagiellońskıego w Krakowie, wraz ze spisem wszystkich rektorów od roku 1400 do obecnej chwili. Kraków 1887 s. LVI. (Odb. z Kronikı Uniwersytetu Jagiellońskiego. 1887 s. III-LXVIII); K. E s t r e 1ch er: Bibliografia polska. Seria I-III T. 1-34 zesz. 1. Kraków 1870-1951 (skrót: Estr.). K. Estre c h e r: Bibliografia polska XIX stulecia. Lata 1881-1900. T. 1-4. Kraków 1906-1916 (skrót: Estr. Ser. IV). T. 20 s. 315-320; J o cher nr 5440, 5443, 8421; Wr. W 1 s lock 1 , Jw. nr 3894, 3942, 4162, 4164 . 
Składk1: 28. Ternion 7. Kwaternion 8. Seksterniony 10, 13, 19. Pozostałe kwinterniony lecz 28 bez $5 \mathrm{k}$.

Filigrany: gołąbek w kole, k. 1, 234. W kole kotwica, ponad nią sześcioramienna gwiazdka, poniżej koła inicjały J. M. k. 131. W owalu kotwica, ponad owalem krzyżyk, ponıżej owalu inıcjały A R, k. 192.

Oprawa $\mathrm{w}$ tekturę szarą szmacianą, obciągniętą $\mathrm{w}$ całości pergaminem. Okładka frontowa 1 tylna lekko uszkodzona, brak części pergaminu. $\mathrm{Na}$ grzbiecie ręczny tytuł: „Tractat. de Trinit[ate], Christo et gratia“. Pod tytułem grzbietowym ornament. Szycie na 4 sznurki zaklejane od spodu. Kapıtałka wyszywana. Brzeg 1 nakrapiane silnıe farbą niebieską.

Proweniencja: 1. „Ex libris M .Antonii Krząnowski S. Th. D. Clepardiensis S. Floriani Prepositi"." Napis na k. 2.

2. Biblioteka OO. Kapucynów. Kraków. Pieczątka okrągła na k. 1v, 128v, 191v, 273v. Sygn.: $10 \mathrm{H}-2$; Nr XL (O. Z. G.) na frontowej wyklejce.

6. Łac. $1714-1715.27 \times 18.5 \mathrm{~cm}$. K. 300. Opr. perg. usp.

1. k. $1-169 \mathrm{v}$. "Tractatus de Deo".

Inc.: k. 2: "Tractationem instituendi mihi de Deo succurnebant $X$ et gratia Deo faventie explicabuntur“. k. 168 .

2. k. $173-258 \mathrm{v}$. "Tractatus de actibus humanis".

Inc.: k. 174: "De bonorum malorumque finibus, deque hominum $\mathrm{X}$ una cum illibata Parente Virgine Maria sit libris hisce felicissimus". k. 258 .

3. k. $263-299 \mathrm{v}$. "De angelis libri $5^{\text {". }}$.

Inc.: k. 263: "Inter Iudaeorum sectas, quae omnium $\mathrm{X}$ succendat, et efficiat flammam ignis. Amen". k. 299.

Szkoła: Seminarium Arcybiskupie w Neapolu. Profesor: Januarius Fortunatus, magister powyższej uczelni. Skryptor: ks. Antoni Krząnowski, późniejszy prepozyt kościoła św. Floriana na Kleparzu w Krakowie.

Reklamanty. Pagınacja oryginalna: nlb. 2, 333, nlb. 9; nlb. 2, 169, nlb. 9; 73, nlb. 3. Karty niezapisane: 1, 170, 171, 172, 173v, 259-262, 300. Spis treścı na k. $168 \mathrm{v}-169 \mathrm{v}, 258 \mathrm{v}, 299 \mathrm{v}$. Na k. 1 i 2 ponad tytułami umieszczony krzyżyk wykonany tuszem. Na górnym marginesie każdej strony krzyżyk. Glosy marginalne na k. 73. Inskrypcje: k. 168: „Anno Dni 1715 die 21 decembris Neapoli sub Rendmo. Dno Januario Fortunato. III. Professore Venerabilis Seminarii Archiepiscopalis“; k. 258: „Neapoli per eundem qui supra anno Domini 1715 mensis 7bris die 10"; k. 299: „Anno Domini 1714 die 26 7brıs. Ab Illri et Renr. Dno P. Januario Fortunato Magistro Seminarii Archiepiscopalis Neapoli“.

Składki: 29. Ternıon 14. Kwaterniony 3, 5, 16, 29. Kwinterniony 4, 6-13, 15, 17-28. Okterniony 1,2 . Kustosze liczbowe tylko od $1-3$.

Filigrany: na wyklejce frontowej lilia. Gwiazda sześcioramienna w kole, ponad kołem krzyż, k. 1. W kole kotwica, ponad nim gwlazdka sześcioramienna, pod kolem inicjały G S, k. 61. Gołąbek w kole, k. 66. Gołąbek w kole z inicjałami A M, k. 170.

Oprawa $\mathrm{w}$ tekturę szarą szmacianą, obciągniętą $\mathrm{w}$ całości pergaminem. Na grzbiecie ręcznie wypisany tytuł: „De Deo. De act. hum. et de angelis“. 
Ornament pod tytułem grzbietowym. Szycie na 4 sznurkı zaklejane od spodu. Kapıtałka wyszywana. Brzeg nakrapiane silnıe farbą niebıeską.

Proweniencja: 1. „Ex libris M. Antonti Krząnowski S. Th. D. et P. Clepardiensis S. Floriani Prepositi". Napis na dolnym marginesie k. 2.

2. Bibliateka OO. Kapucynów. Kraków. Pieczątka okrągła na k. Iv i 299v. Sygn.: $9 \mathrm{~J}-13 ; 10 \mathrm{H}-3$; $\mathrm{Nr} \operatorname{XXXIX}$ (a. Z. G.).

7. Łac. $1731-1733.20 \times 16 \mathrm{~cm}$. K. 288. Opr. ptperg. wsp.

1. k. $1-94$ v. "Theologia sacra. De Deo uno et trino. In primam partem Divı Thomae a quaestione $1 \mathrm{ma}$ ad $43 \mathrm{am}$. ... Die $37 \mathrm{bris}$ anno Dni $1731^{46}$

Inc.: k. $1 \mathrm{v}$ : „De nullo minus proloqui licet $\mathrm{X}$ diximus, scripsimus interminabili semper cedat...". k. $94 \mathrm{v}$.

2. k. 95-147v: "Theologia scholastica de iure et iustitia. In 2dam 2dae Doctoris Angelici a quaestione 57ma ad 81mam. ... Anno Dni 1731 in annum 1732.

Inc.: k. 95v: "Theologia de iure et iustitia 4 distinguemus $\mathrm{X}$ Romanae Ecclesiae iudicio subiectioni cedat.6. k. $147 \mathrm{v}$.

3. k. 149-205. "Theologia scholastica de incarnatione. In tertiam partem Doctoris Angelici a quaestione prima ad vigesimam nonam... In Collegio Societatis Jesu Leopoliensi. Anno Domini 1732 in annum 17331 7bris. Sub. R. P. Josepho Kobielski 1mae lectionis Professore".

Inc.: k. 149v: "Theologiam die incarnatione 4 disputationibus distinguemus $\mathrm{X}$ de identificatis" adequate in mysterio Trinitatis". k. 205 .

4. K. 207-288. "Tractatus theologicus de angelis, fine ultimo et actibus humanis. In 1mam partem Sancti Thomae a quaestione 1ma ard vigiesimam primam. ... In Col. Sieniaviano Athenei Krosnoviani Soc. Jesu. Anno Dni 1732 in annum 17331 7bris".

Inc.: k. 207v: „Ordo ab Angelico Doctore in theologia servatus $\mathrm{X}$ maiorem omnia dicta dictataque cedant". k. 288.

Profesorowie: o. Andrzej Siemiński ${ }^{6}$ T. J. i o. Józef Kobielski ${ }^{7}$ T. J. Skryptor: Dionizy Gradzıński (k. 94v).

Reklamanty. Karty niezapisane: 148, 205v, 206, 288v. Na marginesach numery paragrafów poszczególnych tez i nieliczne glosy.

Skladki: 38. 15 i 18 po $2 \mathrm{k}$. Biniony 11, 16, 24, 27, 37, 38 bez $1 \mathrm{k}$. Terniony

- Ur. 20 VIII 1685, do zak. wstąplf 1703, zm. 26 IV 1768 we Lwowie. - Cat. I Coll. Cracoviensis S. J. A. 1754; Archıwum Romanum Socıetatis Iesu (skrót: ArSI), Pol. 32 nr 4; Cat. brevis Prov. Poloniae Minoris ex a. 1768 un a. 1769; ArSI, Pol. 49; Necrolog1 Prov. Poloniae Min. S. J. 1754-1770; ArSI, Pol. 89 f. 279.

7 Ur. 4 IIr 1693, do zak. wstapił 1709, zm. 2 VIII 1745 w Poznaniu. - Ks. J. B r o w n : Biblioteka pisarzów asystencji polskiej Towarzystwa Jezusowego. Poznań $1862 \mathrm{~s} .221$; $\mathrm{B}$ a c k e rSom m ervoge I IV 1137-1138; Enc. Chetm. XXI-XXII 162. Enc. Orgelbr. XIV 941. Estr. XIX 349; Joch er $\mathrm{nr} 5765 ; \mathrm{W}$. W ą $\mathrm{s} 1 \mathrm{k}$ : Historia filozofii polskiej. Warszawa 1958 s. 75 ; $\mathrm{Bp}$ W. Wó j $\mathrm{c}_{\mathrm{i}} \mathrm{k}$ : Cennıejsze rękopisy bibliotekı Seminarıum Duchownego w Sandomierzu. Archıwa, Bibliot. kośc. T. 4: 1962 s. $298 \mathrm{nr}$ 114; Ks. St. Z a łe sk 1: Jezuic1 w Polsce. T. 1-5. Lwów-Kraków 1900-1906. T. 1 s. 154, t. 2 s. 823. 
12, 13, 21. Kwaterniony 2-10, 20, 22, 23, 26, 28-30 131 bez $1 \mathrm{k} ., 34-36$. Seksterniony $1,14,17,19,25,32,33$.

Filigrany: Myśliwy na konıu, dmący w róg, k. 148. Tarcza herbowa $z$ koroną i krzyżem równoramiennym w polu, k. 205, 206. Pozostałe trudne do zidentyfikowania.

Oprawa w tekturę szarą szmacıaną. Grzbiet i rogi obciągnięte pergaminem złożonym $\mathrm{z}$ dwóch części a okładki papierem czerpanym barwionym na karagenı. Na grzbiecle napıs ręczny tuszem: „De Deo. 2. De incrn. 3. De iure. 4. De angelis“. Szycie na 2 sznurkı. Kapitałka. Brzegi nakrapiane kolorem niebieskım.

Proweniencja: 1. Dionizy Gradzinsklki.

2. Biblioteka OO. Kapucynów. Kraków. Piecząłka okrągła na odwrocie okładki fnontowej it k. 288. Sygn.: $10 \mathrm{~F}-13 ; \mathrm{Nr}$ XXXII (a. Z. G.).

Uwagi: w tekście tytułowym cz. 4 skxyptor popełnił błąd. Omawiane zagadnienia znajdują się w Summie teologicznej św. Tomasza w następujących częściach: „De angelis" I, 50-64, 106-114; „De actibus humanis" I-II, 17, 21; "De fine ultimo" I-II, 1-21; I, 93.

8. Łac. $1733-1735.20 \times 15.5 \mathrm{~cm} . K$. 295. Opr. ptsk. wsp.

1. k. $1-87 \mathrm{v}$. "Tractatus theologicus de gratia divina et peccatis in 1 mam 2dae Doctoris Angelici, a quaestione 109 et quaestione $71 \mathrm{ma}$ ... Sicholasticis disputationibus in Collegio Leopoliensi Societatis Jesu anno salutis 1733 in annum 1734 propositus".

Inc.: k. 1v: "Licet Doctor Angelicus propositis de fine ultimo X gloriae esset tantum meritoria de condigno contritio“. k. 87v.

2. k. 91-156v. "Tractatus theologicus sacramenta novae et antiquae legis explanans. Auditoribus, theologis in Ducali Collegio Leopoliensi Societartis Jesu propositus. Ab anno 1733 in annum 1734 die a 1 7bris...".

Inc.: k. 91v: ,A sacramentis nostra incipit theologia Angelici $X$ de illis dicendum est... Sic proinide. k. $156 \mathrm{v}$.

3. k. 158-209v: "Tractaitus theologicus de virtute et sacramento poenitientiae disputationibus theologicis inter cineres et favillas explicatus. In Collegio Leopoliensi Societatis Jesu... Publice propositus et: anno 1734 in annum 1735 a die 11 7bris sub R. P. Eączyński“".

Inc.: k. 158v: "Quia poenitentia etiam extra sacramentum exerceri pothest $\mathrm{X}$ omnila hactenus dicta et scripta consecnamus". k. $209 \mathrm{v}$.

4. k. 213-295v: "Tractatus theologicus de virtutibus theologicis, fide, spe, charitaite, scholasticis pratelectionibus in Summam Doctoris: Angelici $1 \mathrm{ma} 2$ dae a quaestione 55ta et 2 da 2 dae a quaestione $1 \mathrm{ma}$ elucidatus. Anno Dni quo ignis incineravit Scholas cum templis 1734 in ainnum 1735 die 11 7bris".

Inc.: k. 213: "Angelicus Doctor propositis de gratia divina X obsoIutam charitate quam intensissima terminentur". k. $295 \mathrm{v}$.

Profesor: o. Andrzej Eączyński ${ }^{8}$ T. J. Skryptor nieznany.

- Ur. 29 XI 1697, do zak. Wstapil 1714, zm. 1763 w Krakowie. - Cat. I Coll. Jaroslaviensis. 
Reklamanty. Nieliczne glosy marginalne i interlinealne. Karty niezapisane: 88-90, 157, 210-212. Zakładki $z$ adnotacjami. Na marginesach numery paragrafów bieżących zagadnień.

Składki: 40.22 i 30 po $2 \mathrm{k}$. Biniony 1, 29. Terniony 14, 15, 19. Kwinternion $40 \div 1 \mathrm{k}$. Pozostałe kwaterniony.

Filigrany: tarcza herbowa $z$ koroną i równoramiennym krzyżem $w$ pośrodku, k. 89, 90.

Oprawa w tekturę szarą półtwardą. Grzbiet i rogi sỉ. cielęca barwiona na brązowo. Okładki obciągnięte papierem czerpanym grzebienowym. Sk. na grzbiecie silnıe zmarszczona a od dołu nadtargana. Szycie na 3 więzy. Brzegi nakrapiane na niebiesko i czerwono.

Proweniencja: Biblioteka OO. Kapucynów. Kraków. Pieczątka olkrągła na odwrocie frontowej wyklejki i na wyklejce tylnej. Sygn.: $10 \mathrm{~F}-14$; $\mathrm{Nr}$ LXIV (o. Z. G.) na frontowej wyklejce.

9. Łac. $1735-1738.20 \times 16 \mathrm{~cm} . K .447$. Opr. sk. wsp.

1. k. 1-84. ,Tractatus theologicus de gratia divina. . . Disputartionibus scholasticis in Scholis Collegii Leopoliensis illustratus. Ex anno 1737 in annum 1738. Die 4 ta 7 bris".

Inc.: k. 2: „Exponet hic notitia et divisivo gratiae $\mathrm{X}$ et usu liberi ambitrii. Proinde ut homo indignus practicam... k. 84.

2. k. 85-207. „Tractatus theologicus de angelis, beatitudine et visione Dei ac actibus humanis speculationis scholasticare expositus... In Scholis Leopoliensilbus Societatis Jesu ab anno 1736 in annum 1737. Die 17 ocitolbris".

Inc.: k. 86. „Sequimur item a longe specialem $X$ angelos quos ad primam partem". k. 207.

3. k. 208-274v. "Theologia scholastica de sacramentis novae et antiquae legis... expositis in Scholis Collegii Leopoliensis Societatis Jesu ab anno Dni 1737 in annum 1738. Die 4 ta $7 \mathrm{bris}$ “.

Inc.: k. 209: „Antequam sacramenta in particulari explicent $X$ partis 3 tiae quaestionis 4 , articuli $55^{\prime \prime}$. k. $274 \mathrm{v}$.

4. k. 275-396v. ,Tractatus theologicus de iure et iustitia in 2dam 2dae Divi Thomae a quaestione $57 \mathrm{ma}$ ad quaestionem $80 \mathrm{mam}$ explanatus... In Collegio Leopoliensi Sociertatis Jesu anno Dni 1735to in annum 1736. Die 2da 7bris".

Inc.: k. 276: „Sanctus Doctor Angelicus postquam egit $\mathrm{X}$ et tutelarium perenni cultui consecramus". k. $396 \mathrm{v}$.

5. k. 399-409. ,Tribunal sacrum seu ius canonicum in quo de processu iuris ild est de ordine in iudliciis spiritualibus servando ad normam Libri 2di Decretalii nec non de vita clericorum, praebendis et dignitatibus ad mentem Libri 3 tii Decretalium partis 1 mae agetur. In Scholis Leopoliensibus Societatis Jesu. Ex anno Dni 1736 in annum 1737“.

ad BVM a. 1754; ArSI, Pol. 32 f. 152 nr 5; Necrol. Prov. Poloniae Matoris S. J; ArSI, Pol. 86 f. 157 ; Ks. St. Z a 1 ę s k 1, Jw. T. 2 s. $660,901$. 
Inc.: k. 399v: „Praesens opus bipartitum erit. lma pars X deducit id ex canone decrevimus". k. 409.

6. k. 413-417v. ,Theologila polemica. Quaestiones controvensaie fidei catholicae cum haeneticis praecipue de iustificatione, de sacramentis et de sacramento eucharistiae resolvens. . Die 11 7bris anno $1737^{*}$.

Inc.: k. 413: „Plurimi sunt errores hereticorum ciraa iustificationem $\mathrm{X}$ producit quosdam textus ex d[ivina] glo[ria]“. k. $417 \mathrm{v}$.

7. k. 420-427. „Quaiestiones canonicae in Librum 3tium Decretalium iuxta praescriptum anni praesentis de immunitate ecclesiastica, conservatione ac execratione... ac in Sieniaviano Collegio Leopoliensi in Aula Krosnoviana munificentiae in usum pro futuris auditoribus et lectoribus extraditae. Ex anno 1737 in annum Deo dante 1738 die $107 \mathrm{bris}$."

Inc.: 420v: „Super vacaneum esset sacros auditioribus X Lib. Numero 103 in Digestis". k. 427.

8. k. 428-432v. ,Theologia moralis. Casus conscientiae die sacramentis. Praesertim de matrimonio, de communione et sacrificio Missae complectens... Anno Dni 1737 Die 10 7bris".

Inc.: k. 428v: "Triplici tractatu praesentem absolvemus materiam $\mathrm{X}$ Reginaldus, Azor, Gonzales, Lugo, Tamburinus". k. 432v.

9. k. 434-446v. ,Theologia moralis. De praeceptis 1 mae et 2 dae tabulae. Item de conscientia, voluntario et actibus humanis practice. Anno Dni 1736 in annum 1737 in Scholis Leoburgicis Societatis Jesu evolvendis conscientiae nodis exposita...".

Inc: k. 434v: , 1. Innocentius 10 mus et Alexander 7 mus $\mathrm{X}$ immo nec potest scire quid est Missla“. k. 446v.

Profesorowıe: o. Kanty Bielicki ${ }^{9}$, o. Andrzej Łączyński, o. Andrzej Siemińskı T. J. Liczne czyste karty śwıadczą o niewykończeniu poszczególnych zagadnień teologicznych. Karty niezapisane: $60 \mathrm{v}, 61-64,67 \mathrm{v}, 68,69,79 \mathrm{v}, 80$, $81 \mathrm{v}, 84 \mathrm{v}, 207 \mathrm{v}, 230 \mathrm{v}, 251 \mathrm{v}, 252-255,258 \mathrm{v}, 259-260 \mathrm{v}, 262,263,267-269 \mathrm{v}, 275 \mathrm{v}$, $397,398,409 \mathrm{v}, 410-412,418,419,427 \mathrm{v}, 433,447$.

Składki: 55. Biniony 16, 17, 30. Ternıon 52+1k. Kwinterniony 3, 10, 24, 31. Seksterniony 18, 23, 26, 34. Pozostale kwaterniony ale 15 i $33+1$ k., 53 i 54 bez $2 \mathrm{k}$.

Filigrany: brak znaków wodnych.

Oprawa w calą sk. cielęca barwioną na brązowo. Grzbiet zamalowany W całoścı na szaro z napisem týlułowym: "Tractatus de gratia in Schola S. J." Szycie na 3 sznurki. Kapitalka wyszywana ręczne.

Proweniencja: 1. Biblioteka OO. Kapucynów w Olesku. Pieczątka okrągła na k. 1, 222, 393. Sygn.: XIII 2.

2. Biblioteka OO. Kapucynów. Kraków. Pieczątka okrągła na frontowej wyklejce, $446 \mathrm{v}, 87 \mathrm{v}$.

9 U1. 19 X 1694, do zak. Wstąpił 1711, zm. 1769 W Krakowie, - Cat. I Coll. Posnaniensis S. J. a. 1754; AlsI, Pol. 32 f. 284 nr 6. Data śmıercı znana z zapisków ks. Załęsklego pt. .Bibliographica varıa" (w Archiwum OO. Jezuitów w Krakowie). 
10. Łac. 1742. $20 \times 16.5 \mathrm{~cm}$. K. 241. Opr. sk. wsp.

Theologia speculativa.

Inc.: k. 9: „Priusquam ad augustum illud de Deo ac donis $\mathrm{X}$ sicut ir Patre prioritas et spiratio activa". k. 239v.

Treść: „Praeambulum de ipsa theologia“, k. 9-26. „Tractatus 1mus de Deo uno", k. 27-180v. "Tractatus 2dus theologiae speculativae de Deo trino", k. $181-239 \mathrm{v}$.

Kodeks powstał prawdopodobnie w jednej ze szkół teologicznych polskıch misjonarzy. Reklamanty. Paginacja oryginalna od k. $181-239 \mathrm{v}$, oznaczona od s. $1-96$. Karty niezapisane: $1-8,56,57,58 \mathrm{v}, 176 \mathrm{v}, 177-179$. Wlepione liczne wkładki z uzupełnıenıami do tekstu. Glosy marginalne.

Składki: 43. Biniony 3-23, 25, 26, 35. Terniony 2, 24, 27-34, 36-43. Kwaternion 1.

Filigrany: inicjały J J K (?), k. 4, 5. Jeździec w rokokowym kapeluszu na koniu w bregu, k. 56, 57, 177. Lilia, k. 178, 179.

Oprawa twarda w cała sk. cielęcą barwioną na brązowo. Od strony grzbietu linie tłoczone na ciemno. Szycie na 3 sznurki. Kapitałka wyszywana. Brzegi kolorowane na czerwono.

Proweniencja: 1. „Ex libris Cong[regątiomis] Miss[ionis]. Domus Vladis[1aviensis]“. Napis na k. 9.

2. Biblioteka OO. Kapucynów w Olesku. Pieczątka okrągla na k. 9, 107 i 203. Na grzbiecie sygn.: XIII 12.

3. Biblioteka OO. Kapucynów. Kraków. Pieczątka okrągła na k. 8v, 239v.

11. Łac. $1743.22 \times 18 \mathrm{~cm}$. K. 413. Opr. sk. wsp.

Theologia speculativa.

Inc.: k. 1: „Et incarnationis nomen quibusdam haereticis $\mathrm{X}$ et poenam propriam impedire. Post hoc sequitur tractatus de restitutione". k. 413.

Treśc: Tractatus de ineffabilı Verbi Divini incarnatione, k. 1-80; Tractatus de angelis, doemonibus et primo homine, k. $81-113 \mathrm{v}$; Tractatus de beatitudine supernaturali et ultimo fine hominis, k. 117-144; Tractatus de virtutibus theologicis, fide, spe et charitate, k. 145-189; Tractatus de legibus, k. 190-233v; Tractatus de gratia, iustificatione et merito, k. 237-296v; Tractatus de virtute et sacramento poenitentiae, extrema unctione et ordine, k. 297-343; Disputatio de uustitia in celebrandis contractibus in genere, k. 345--382v; Tractatus de iure et iustitia, k. $383-413 \mathrm{v}$.

Rękopis teologiczny $\mathrm{z}$ studium domesticum jednego $\mathrm{z}$ klasztorów kapucyńskich prawdopodobnie czeskich. Karty niezapisane: $80 \mathrm{v}, 114,115 \mathrm{r}, 116,144$, $189 \mathrm{v}, 234,235,272 \mathrm{v}$. Karty wydarte: po k. 80 kart 4, po 189 kart 3. Numery paragrafów poszczególnych zagadnień na marginesach. Glosy marginalne $i$ interlinearne. Kursywa kodeksu posiada wiele elementow niemieckiego pisma gotyckiego. Inskrypcje: k. 154: „In conversione Sancti Pauli 1743;“ „31 ianuarii finıvimus anno $1743^{\prime \prime}$.

Składki: 68.68 ma 2 k. Biniony 8, 13, 16, 24, 38, 48, 58, 60, 62, 64, 67 . Kwaterniony 7,14 bez $4 \mathrm{k}$. wyciętych, $19,25,26,30$ bez $3 \mathrm{k}$. wydartych, 47 , $57,59,63,66$, bez $2 \mathrm{k}$. Seksterniony 15, 29. Pozostałe terniony. Kustosze $\mathrm{w}$ górnym marginesie.

Filigrany: koło $\mathrm{z}$ krzyżem $\mathrm{w}$ górze i literą $\mathrm{N}$ w górnej części koła, pođ kołem data $1741, \mathrm{k} .3$, 4. Tarcza herbowa z krzyżem w środku, ponad tarczą 
infuła i pastorał, k. 188, 189. Litera $K$, k. 413. Tarcza herbowa $z$ koroną pięciopałkową na frontowej wyklejce. Tarcza herbowa z koroną i dwugłowym orłem na wyklejce tylnej.

Oprawa w tekture szarą obciągnıętą $w$ caloścı sk. cielęcą barwioną na brązowo. Sk. na grzbiecie w górnej i dolnej części zetlała, odpadła i popẹała na zawiasach. Szycie na 4 więzy. Brzegi czerwone. Dwie pary tasiemek zielonych dodanych później.

Proweniencja: Biblioteka OO. Kapucynów. Kraków. Pieczątka okrągła na odwrocie wyklejki frontowej i $k$, 413v. Sygn.: 10-18; Nr LXVI (o. Z. G.).

12. Łac. $1743.20 \times 16 \mathrm{~cm}$. K. 216. Opr. sk. wsp.

Theologia speculativa.

Inc:: k. 3: „Supposita Dei natura in Xto $\mathrm{D}$ [omino] X iustificañtem consistere potest in habitu charitatis". k. $215 \mathrm{v}$.

Treść: „Tractatus 3tius de misterio incarnationis", k. 4-135v; "Tractatus de gratia", k. 136-215v.

Kodeks powstał prawdopodobnie w jednej ze szkół teologıcznych polskich misjonarzy. Reklamanty. Liczne wklejkı z uzupełnıenıamı do tekstu: 5a, 6a, $8 \mathrm{a}, 9 \mathrm{a}, 13 \mathrm{a}, 17 \mathrm{a}, 21 \mathrm{a}, 26 \mathrm{a}, 27 \mathrm{a}, 28 \mathrm{a}, 29 \mathrm{a}, 30 \mathrm{a}, 32 \mathrm{a}, 33 \mathrm{a}, 35 \mathrm{a}, 36 \mathrm{a}, 38 \mathrm{a}$, $40 \mathrm{a}, 44 \mathrm{a}, 44 \mathrm{~b}, 54 \mathrm{a}, 60 \mathrm{a}, 76 \mathrm{a}, 78 \mathrm{a}, 112 \mathrm{a}, 112 \mathrm{~b}, 136 \mathrm{a}, 144 \mathrm{a}$. Karty niezapisane: $1,2 \mathrm{v}, 85 \mathrm{v}, 86,87,91,130,200 \mathrm{v}, 211,216$ - Glosy marginalne. $\mathrm{Na}$ marginesach numery paragrafów poszczególnych zagadnień. Inskrypcje: k. 126: „Die 24 ianuarii anno Dni 1743:“ k. 136: „27 ianuarii 174.3;" k. 200: „Anno D. 1743 die 21 maii".

Składkı: $37.10,12,15$ po 2 k. Biniony $6,13,14,17,22,23,24,37$. Terniony $3,4,5,7,8,11,16,18-21,25-35$. Kwaterniony $1+1 \mathrm{k} ., 2,9$. Kwinternion 36 .

Filigrany: lilia, k. 1, 2. Mężczyzna z kielichem i kobıeta z bukietem kwlatów, ponad nimi napis: Egerndorf, k. 91, 130. Jeździec w rokokowym kapeluszu na koniu w biegu, k. 85, 87.

Oprawa twarda $w$ całą sk. cielęcą barwioną na brązowo. Od strony grzbietu linie tłoczone na ciemno. Grzbiet w górnej i dolnej czesści uszkodzony. Szycie na 4 sznurki. Brzegi kolorowane na czerwono. Kapitałka wyszywana.

Proweniencja: 1 „Ex libris Congregationis Mliss[ionis] Domus VladisI[aviensis]”. Napis na k. 2.

2. Biblioteka OO. Kapucynów w Olesku. Pieczątka okrągła na k. 3, 101, 193. Sygn.: XIII 13.

Biblioteka OO. Kapucynów. Kraków. Pieczątka okrągła na k. 3v, 215v.

13. Eac. 1743-1744. $21 \times 16.5 \mathrm{~cm} . K$. 197. Opr. plsk. wsp.

1. k. 3-40, ,Tractatus IV de gratia eiusque effectibus nempe iustificatione et merito. Inceptus in Conventu nostro Varsaviensi vicesima die februarii".

Inc.: k. 4: "Tractatus quem hodie aggredimur quemadmadum $\mathrm{X}$ ad merendum et demerendum libertatem a coactione sufficere'. $\mathrm{k} .40 \mathrm{v}$.

2. k. 44-127v. ,Incipit Liber Sententiarum III de divini Dominicae incarnationis misterio. Qui feliciter, et laetanter a nobis exorsus est tertio Idus maii Varsaviae". 
Inc.: k. 54v: „In omni scientia exoriendum est a nominibus $\mathrm{X}$ et hoc modo sacrificium offerri potest". k. $127 \mathrm{v}$.

3. k. 128-147. „Tractatus ultimus de angelis brevis quia abreviatus fuerat".

Inc.: k. 128v: "Contemplata pro intellectus homini imbecillitate $\mathrm{X}$ quod admittunt angeli in primo instanti. Finis". k. 147.

4. k. 148-185. "Additamentum ad prologum pro pleniori sacrae scripturae cognitione".

Inc.: k. 148: „Dividemus hoc additamentum in tres quaestiones $\mathrm{X}$ angelus iille repraesientabat personam Dei“". k. 185.

5. k. 186-193. „Recensentur et explicantur casus reservati regularium".

Inc.: k. 186: „Quaemadmodum pontifex pro tota ecclesia X possunt a casibus reservatis regularibus hic. ." k. 193v.

6. k. 194-197. Druk: "Currus et auriga in hac Scotica Quadriga a Sorbonico foecundas, advehens merces Sarmaticas seu Theses ex universa theologia scholastica iuxta ordinem quatuor Librorum Sententiarum ex doctrina doctoris sorbonici Ioannis Duns Scoti collectae. Honori et venerationi speciosae matris Mariae Theresiae Ungariae Boëmiae bis reginae. Illustrissimi D.D. Wilhelmi Kinner Liberi Baronis de Scharffenstein consiliarii et ministri residentis in Polonia, patroni et protectoris gratiosissimi, a s.s. theologiae studio Ordinis F.F. Minorum S. P. N. Francisci Capucinorum Regii eiusdem ordinis Conventus Varsaviensis dictae. Praeside A. V. P. Constantio Capucino Provinciae Boëmiae professo s.s. theologiae lectore. Defendente V.P. Liborio Königsfeldiense professo Poloniae s.s. theologiae alumno propugnatae horis ante et post meridiem consuetis die 22 aprilis".

Lektorzy: o. Elzeariusz ${ }^{10}$, Czech, wykładał do 29 lipca 1743. Po nım wykłady prowadzil o. Konstanty ze Swidnicy ${ }^{12}$, Slązak. Obaj należeli do czeskiej prowıncji kapucynów. Skryptor: o. Liboriusz KönigsfeldenSis ${ }^{12}$, Czech.

10 Do zak. Wstąpił $16 \mathrm{~V}$ 1721, zm. $8 \mathrm{~V} 1758$ w Pradze na Hradczynue. - Por. Syllabus patrum ac fratrum ordinis Minorum Capucinorum Provinciae Bohemias et Molaviae ac Custodiae Silesiae ab anno MDC Domino defunctorum, noviter conscriptus anno 1782. (Archrwum Archidiecezjalne we Wrocławiu. Sygn. V 90).

11 Do zak. wstąpil 6 X 1723, z.m. 9 VI $1746 \mathrm{~W}$ Krakowie, - Syllabus, Jw.; Mortuologium seu calendarium patrum et fratrum oldinis Minorum S. P. Francisci Capucinorum in Provincia Polona mortuorum, ex mandato A. R. P. Stanıslal a Maxkuszovia minıstrı prowincialis conscriptum anno Dominl 1791. Pro Conventu Cracoviensi. AKK. Sygn. 22. Autor mortuologium zaznacza, ze o. Konstanty przeszedł z prowincji czeskiej do kustodii polskiej, w której przeprowadzil dwa kursy teologiczne w charakterze lektora (6 lat).

12 Ur. 4 XII 1719, do zak. wstąpił 1738, zm. $21 \mathrm{~V} 1759$ we Lwowle. Lektor, sekr. prow., rubrycysta. - Cathalogus patrum Ordinis Minorum S. P. Franciscl Capucinorum Provinciae Polonae alumnorum. Enumeratus ab anno 1697. Katalog znajduje sie w rękopisıe Bibl. Unıw. warsz. pt. ..Chronologica brevis adnotatio institutionis et progressus Ordinis nostri atque 
Tytuły wykonane recznie $w$ formie liter drukowanych. Reklamanty. Karty niezapisane: 1v, 2, 3v, 41, 42, 43, 44v, 147v, 185v. K. 51 i 52 oderwane. Każda strona znaczona w górnym marginesse krzyżykiem. Dukt pisma lukowaty. Glosy margınalne i interlınearne. Na uwagę zasługują podane w tekście imıona siuchaczy, którzy rozwiązywali dane zagadnıenia. Np. k. 4: „V. P. Dominicus“; k. 45v: "Martinus et Caletan[us];" k. 47: „Domi[nicus] et Ezechi[el]". Inskrypcje: k. 62v: "Vigesima nona iulii a nobis fauste finita fuerunt scripta nostri Reverendi Patris Elzeari. Quinta vero augusti incepımus non sine gaudio scripta novi professoris nempe Admodum Venerandi ac in Christo observantissimi Patris Constantii Svidnicensis ut sequitur;“ k. 127v: „Iste praesens misteriosus tractatus laetanter finitus fult sexto Idus aprilis".

Składki: $25+4$ k. druku. Biniony 1, 19. Kwinterniony 2, 14. Pozostałe kwaterniony. Kustosze liczbowe $(1-10)$, dalej brak.

Filigrany: tarcza herbowa $z$ korona podtrzymywana przez dwa lwy, w herbie trzy krzyżykı w linii pıonowej, k. 44. Matka Boska z Dzıeciątkiem w otoku promieni, k. 128, 147.

Oprawa w tekturę. Grzbiet i rogi skórzane. Okładki obciągnięte papıerem czerpanym kolorowanym na brązowo. Górna część okładki pęknıęta na grzbiecie. Szycie na 2 paskı pergaminowe. Brzegi nakrapiane farbą niebieską.

Proweniencja: 1. O. Liboriusz Königsfeldensis.

2. Biblioteka OO. Kapucynów Kraków. Pieczątka okragła na k. 3v i wyklejce tylmej. Sygn.: $9 \mathrm{D}-16$; Nr XXVI (o. Z. G.).

14. Łac. $1743-1744.20 \times 16.5 \mathrm{~cm}$. K. 170. Opr. ptsk. wsp.

,Tractatus theologici de Deo uno et trino. Menti Subtilis Doctoris Ioannis Duns - Scoti conformes ab Admodum Reverendo P. Elzeario Porzicensi p.t. Ss. theologiae lectore, nec non actuali Almae Custodiae Polonae consultone. Descripti vero a Fratre Liborio Königsfeldensi praefati studii auditore. Faventibus nobis superis faustis incepti et exorsi nona decembris anno ut patet".

Inc.: k. 6: "Theologiae sacraria adituri relictis peri[culum] X sancti ergo hoc sensu libera est". k. 170v.

Szkoła: Studium domesticum kapucynów w Warszawıe. Tak część tytulatury jak też tytuły 1 podtytuły rozdziałow wypisane ręcznym pısmem w formie liter drukowanych. Za kartą tytułową wlepione tezarium z tych lat. Rękopıs nosi wybitne cechy niemieckıego pısma gotyckiego i wykonany został duktem łukowatym. Każda strona znaczona krzyżykiem $\mathrm{W}$ górnym marginesie. W kodeksie podano następujące imıona słuchaczy: Barnaba, Domınik, Ezechiel, Izajasz, Jeremıasz, Kajetan, Liborıusz, Marcin, Mateusz, Sebastıan. Inskrypcja na końcu rękopisu: „Superno favore fauste finitus est tractatus SS. Trinitatıs decima quinta februarii MDCCXXXXIV".

Składki: $23.2+3 \mathrm{k}$., 13 po $2 \mathrm{k}$. Terniony 1, 3, 12. Kwinternion 15. Pozostałe kwaterniony lecz 23 bez $1 \mathrm{k}$. Kustosze liczbowe od I-XXII.

Filigrany: litera $\mathrm{Z} \mathrm{w}$ winletce, wyklejka frontowa. Tarcza herbowa $z$ koroną i trzema krzyżykami w polu w linii pıonowej, tarczę podtrzymują dwa lwy, wyklejka tylna, k. 77, 78.

status nostrae Provinciae Polonae ex actis capitulorum et anialibus Provincıae" (skrót: CPP) od k. 35. Sygn. 1, 7, $12 \mathrm{nr} 53$. 
Oprawa w tekturę szarą szmacianą. Grzbiet i rogı obcıągnięte sk. cielęcą barwioną na brązowo, a okładki papierem czerpanym barwionym klajstrowo na brązowo. Prawy róg oprawy frontowej uszkodzony jak 1 dolna część grzbıetu. $\mathrm{Na}$ grzbıecie sk. popękana. Brzegi nakrapiane na niebıesko.

Proweniencja: 1. O. Liboriusz Königsfeldensis.

2. „Loci PP. Capucinorum Cracoviae“. Napis na frontowej wyklejce. Pieczęć okrągla z napisem: „Biblioteka OO. Kapucynów. Kraków" na wyklejce frontowej v. i tylnej r. Sygn.: $9 \mathrm{D}-12$; $\operatorname{Nr} \operatorname{LXXIV}$ (o. Z. G.).

15. Eac. $1754-1755.20 \times 15.5 \mathrm{~cm}$. K. 280. Opr. płsk. wsp.

1. k. 4-153. „Theologia scholastica tractatum de virtutibus complectens. In Scholis Palatinis Collegii Leopoliensis Societatis Jesu explanata. Anno Dni 1754 in 1755 annum".

Inc.: k. 5: „De virtutibus S. Th[omas] ait 1ma 2dae a quaest. 55 $\mathrm{X}$ pertingere et Dei est et similes quantum conceditur". k. 153 .

2. k. 156-276. "Tractatus theologicus de poenitentia in 3tiam partem Divi Thomae a quaestione 84 ad finem eiusdem partis... In Collegio Leopoliensi Soc. Jesu anino Dni 1754 in annum 1755tum".

Inc.: k. 158: „Notitia enim virtutis haberi vix potest $\mathrm{X}$ operatum cedat ad fructum poenitentilae". k. 276.

Profesorowie: o. Aleksander Brodowski ${ }^{13}$ lub o. Michał Orłowski ${ }^{14}$ T. J.

Reklamanty. Karty niezapisane: 1v, 2, 3, 153v, 154, 155, 157v, 276v, 277280. Na margınesach numery paragrafów.

Składki: 26. Biniony 17, 18. Kwaterniony 10, 12, 14, 16, 19, 24, 26, 27, $28+3$ k. Kwinterniony 2, 3, 4, 5, 6, 8, 9, 16. Seksterniony 11, 13. 20, 21, 22, 23, 25. Septentriony 1, 7, 15.

Filigrany: Matka Boska z Dzieciątkiem w otoku promieni, k. 106. Inicjały I E z koroną ponad nimi, k. 1. Inicjały G R, k. 153. Napis P I H, k. 108.

Oprawa półmiękka w tekturę szarą szmacıaną. Grzbiet i rogi sk. cielęca barwiona na brazowo. Grzbiet cały zamalowany farbą, u góry napis tytułowy. Okładki obciągnięte papıerem czerpanym klajstrowym. $\mathrm{Na}$ frontowej wyklejce fragment rękopisu cyrylicą. $\mathrm{Na}$ tylnej fragment $\mathrm{z}$ traktatu teologicznego. Szycie na 3 sznurki.

Proweniencja: 1. „Ex libris Pauli Krohliński, mpp. Napis na frointowej wewnętrznej okładice.

2. Bibliotekja OO. Kapucymów w Olesku. Pieczątka akrągła na k. 4, 101, 196. Sygn.: XIII 1.

3. Biblioteka OO. Kapucynów. Kraków. Plieczątka okrągła na k. 4v, 276v.

16. Eac. $1756-1757.20 \times 15.5 \mathrm{~cm}$. K. 370. Opr. plsk. wsp.

1. k. $1-220 \mathrm{v}$. "Theologia scholastica tractatum de incarnatione Verb,

13 Ur. 12 I 1716, do zak. wstapil 1732, zm. 17 VIII 1782 (?) we Lwowie. - B a cke r S o m mervogel II 195-156 (podaje inne daty urodzenı 1 wstąpienia do zakonu); B $\mathrm{r}$ o w n, JW. s. 134; Enc. Cherm. V/VI 159; J o cher $\mathrm{nr} 3295,3832,4723$.

14 Ur. 9 V 1710, do zak. wstąpil 1725. W chwili kasaty był prowincjałem rrowincji wielkopolskief. - Catalogus personarum et ofticiorum Provinciae Poloniae Masorıs S, J. ex a. 1773 in a. 1774. Posnaniae s. 1; Bp W. Wó J $\mathrm{c}_{\mathrm{l}} \mathrm{k}$, Jw. s. $300 \mathrm{nr} 121$; E s tr. XXIII 430. Ks. St. Z aię k i, jw. T. 1 s. 476 , t. 2 s. 1012, t. 3 s. $113 \check{s}$. 
Divini complectens. In Scholis Palatinis Collegii Leopoliensis Societatis Jesu anno 1756 in 1757 explanata".

Inc.: k. 2. "Inter antecedentia incarnationem Verbi Divini $\mathrm{X}$ lectione vel concussa ratione corrigere". k. $219 \mathrm{v}$.

2. k. 221-369v. "Tractatus theologicus de angelis de quilbus Doctor Angelicus 1ma parte a quaestione 50 ad quaestionem 65 exclusive, de beatitudine de qua idem Doctor 1ma 2dae a quaestione 2da, et alibi sparsim. Tum demum de actibus humanis de quibus idem Divus Thomas ex eadem 1ma 2dae pluribus ait... In Collegio Leopoliensi Soc. Jesu. Anno Dni 1756 in 1757 annum".

Inc.: k. 222: „De essentia philosophica et metaphisica angelorum $\mathrm{X}$ omnia et singula hactenus dicta referre". k. $369 \mathrm{v}$.

Profesorowie prawdopodobnie jak pod nr 15. Reklamanty. Karty niezapisane: $221 \mathrm{v}, 370$. Na marginesach numery paragrafów. Glosy marginalne występują rzadko.

Składki: 46. 29 ma $2 \mathrm{k}$. Terniony 2, 4, 6, 8, 10, 12, 14, 18, 20, 22, $24,26,31,35,37,39,41,43,45$. Kwaterniony 1, 16, 30, 33. Kwinterniony 3, 5, $7,9,11,13,15,17,19,21,23,25,27,28,32,34,36,38,40,42$, 46. Seksternion 44 .

Filigrany: na frontowej wyklejce fragment filigranu roślinnego, na tylnej część filigranu $\mathrm{z}$ inıcjałami S C M. Matka Boska z Dziecıątkiem w otoku promieni, k. 9. Pod zdobnikiem ınıcjały P S H, k. 10, 11.

Oprawa twarda w tekturę szarą szmacianą. Grzbiet w całości pomalowany farbą olejną $z$ napısem tytułowym ręcznym. Okładki obciągnıęte papierem klajstrowym brązowym. Szycie na 3 sznurki.

Proweniencja: 1. Biblioteka OO. Kapucynów w Olesku. Pieczątka okrągła na k. 1, 179, 310. Sygn.: XIII 34.

Biblioteka OO. Kapucynów. Kraków. Pieczątka okłrągka na frontowej wyklejce, k. $220 \mathrm{v}, 369 \mathrm{v}$.

17. Eac. 1757-1758. $20 \times 16 \mathrm{~cm} . K .219$. Opr. ptsk. wsp.

1. k. 4-96v. "Tractatus theologicus de gratia, merito et demerito. Quam materiam Divus Thomas in sua Summa prima secundae a quaestione septuagesima prima tum etiam a quaestione centesima nona discutit. Explanatus in Collegio Leopoliensi Societatis Jesu anno Domini $1757^{\prime \prime}$.

Inc.: k. 5: "Circa gratiam divinam auxiliantem 1 mo erravit $X$ de gratia Dei hactenus percepimus, totum nefenamus". k. $94 \mathrm{v}$.

2. k. $100-218 \mathrm{v}$. "Tractatus theologicus de sacramentis scholasticis disputationibus explanatus... in Scholis Collegii Leopoliensis Soc. Jesu anno Dni 1757 in 1758 annum die 2 7bris".

Inc.: k. 101: „Ut recte atque ordine procedatur $\mathrm{X}$ ad iudices ecclesiasticos, anathema sit". k. $216 \mathrm{v}$.

Profesorowie: o. Aleksander Brodowski lub o. Jan Łucki ${ }^{15}$ T. J.

15 Ur. 20 V 1714, do zak. wstąpil 1730. W chwili kasaty przebywał w Lublinie. - Cat. 
Reklamanty. Karty niezapisane: 95, 97-99, 217, 219. Indeksy: k. 96, 218. $\mathrm{Na}$ marginesach numery paragrafów. Nieliczne glosy. $\mathrm{Na}$ frontowej wyklejce tytul: „Tractatus theologiae scholasticae anni 4 ti. De gratia et sacramentis".

Składkı: 27. Kwaterniony.

Filigrany: dwie lilie, k. 3, 218. Jeździec na koniu, przed koniem wysoki krzyż, k. 95, 99. Orzeł, k. 98. Matka Boska z Dzıeciątkıem w otoku promieni, k. 216.

Oprawa twarda w tekturę szarą szmaciana. Grzbiet i rogi sk. cielęca barwiona na brązowo. Grzbiet w całości pomalowany farbą olejną z napisem tytułowym. Okładki obciągnięte brązowym papierem czerpanym. Szycie na 3 sznurki. Brzegi nakrapiane.

Proweniencja: 1. „Ex libris Pauli Krohliński, mpp.“ Napis na tylnej wyklejce okkadki.

2. Bibliateka OO. Kapuicynów w Olesku. Pieczątka okrągła na k. 4, 93, 192. Sygn.: XIII 36.

3. Biblioteksa OO. Kapucynów. Kraków. Pieczątka okrągła na k. 3v, 218v

18. Eac. $1761-1762.19 .5 \times 11.5 \mathrm{~cm}, K$. 318. Opr. sk. wsp.

1. k. 3-128. "Tractatus theologicus de sanctissimis ecclesiae sacramentis ex annio 1761 in anmum 1762 expositus“.

Inic.: K. 4: "Viox haec sacramentum idem somat latinis $\mathrm{X}$ et sanguis meus vere esit potus". k. $128 \mathrm{v}$.

2. k. 131-253v. "Tractatus theologicus de gratia divina, merito et peccatis scholasticis disputationibus explanatus... Leopoli in Universitate Soc. Jesu anno Dni 1761 die $17 \mathrm{bris}^{6 *}$.

Inc.: k. 132: "Gratia divina in praesenti consideranda X item odium et detestationem peccati. Ses. 6 , cap. $6^{66}$. k. $253 \mathrm{v}$.

3. k. $257-289 \mathrm{v}$. "Propositiones dogmaticae de sacramentis eorumque praecipuo effectu nempe de iustificatione adversus haeresum impugnationes in Universitate Leopoliensi Soc. Jesu theologice propugnatae anno 1761 a die 2 7bris".

Inc.: $k .258 \mathrm{v}$ : "Cum variarum sectum authores eorumque $\mathrm{X}$ in aliud nequit et unio. 80. Opponunt $1 \mathrm{mo}^{6 \%}$. k. $289 \mathrm{v}$.

4. k. 291-314. "Introductio in veram atque germanam sacrarum literarum intelligentiam per comentationem in libiros tum Novi tum Veteris Testamenti adiectis $\mathrm{m}$ [ere] resolutionibus doctae curiositati et necessariae doctrinae servientium. Anno Dni 1761 die $27 \mathrm{bris}$ “.

Inc: $\mathrm{k} .292 \mathrm{v}$. "Ea quae totam slacram scripturam X depositam damnatis eleemosinas distribuebanit". k. 314 .

Profesorowie: o. Aleksander Brodowski lub o. Jan Łucki. Nr 4: o. Ignacy Odrzywolski ${ }^{13}$.

pers, et offic. Prov. Polonıe Minoris ex a. 1772 in a. 1773. Premıliae 1773 s. 13; Bp W. W ó $f$ c i k, jw. s. $298 \mathrm{nr} 114$.

16 Ur. $25 \mathrm{~V}$ 1721, do zak. wstąpił 1738. W czasie kasaty byl prof. teologii scholastycznej w Frzemyślu. - Tamize s. 23. 
Reklamanty. Karty niezapisane: 1, 2, 3v, 105v, 129.130, 131v, 254-256, $257 \mathrm{v}, 290,291 \mathrm{v}, 314 \mathrm{v}-318$. Numery paragrafów na marginesach.

Składkı trudne do obliczenia.

Filigranów brak.

Oprawa jak pod nr 17.

Proweniencja: 1. „Ex Bibl. PPب Capuc. Mariampol[iensium]. Napıs inną i późniejszą ręka na k. 3 tytułowej.

2. Biblioteka OO. Kapucynów w Olesku. Pieczątka okrąła na k. 3, 101, 235. Sygn.: XIII 47.

3. Biblioteka OO. Kapucynów. Krików. Pieczątka akragła na k. 3v, $314 \mathrm{v}$.

19. Eac. 1769. $22 \times 17.5 \mathrm{~cm}$. K. 275. Opr. brosz. wsp.

Theologia speculativa.

Inc.: $k$. 1: ${ }_{9}$ Omnis perfectae scientiae munus esit indagari $\mathrm{X}$ atque haec scripta de sacramentis in genere cedlant". k. $275 \mathrm{v}$.

Treść: „Tractatus 1mus de Deo uno“, k. 1-72v. ,Tractatus II. De Deo trino", k. 73-107v. "Tractatus III. De angelis et primo homine“. k. 108-123v. „Tractatus VIII. De gratia Chmsti“, k. 121-162. ,Tractatus IX. De Dominicae incarnationis misterio", k. 162v-201v. ,Tractatus X. De virtutibus theologicis“, k. 202-232v. „Tractatus XI. De sacramentıs in genere“, k. 234-275v.

Szkoła: Studium domesticum $w$ jednym $z$ klasztorów kapucyńskich. Lektor: prawdopodobnie 0. Szymon Sikorski ${ }^{17}$. Skryptor: o. Walenty Wróblewski ${ }^{18}$.

Reklamanty. Karty niezapisane: 233. Na margınesach numery paragrafów. Kursywa drobna 1 mało czytelna. $\mathrm{Na}$ k. 243v nalepiono kartę $\mathrm{z}$ tematem kazusu na konferenıję moralna pt. "Conferentia moralis". Akt ten wykonał i podpisał: „fr. Simon a Lipnica Cap., 3 augusti 1769 ".

Składki: 35. Binion 14. Seksternion 32 bez 2 k. Pozostale kwaterniony.

Filigrany: inicjały I P, k. 2, 7; A I, k. 233. Napis: Troppau, k. 271, 272. Matka Boska z Dziecıątkiem w otoku promieni, k. 227, 232. Mężczyzna z laską (Mojżesz?), k. 270.

Oprawa w całą tekturę szarą obciągniętą w grzbiecie papierem czerpanym naturalnym. Na okładce papier klajstrowy marmurkowy brązowy. Szycie na 2 sznurki naklejane mıędzy podwójnie złożone wyklejkı.

Proweniencja: 1. „Fr. Valentini Capucini". Napis na cidwrocie frontowei olkładki.

2. Biblioteka OO. Kapucynów. Kraków. Pieczątka akırągła na wyklejce frontowej v. i okładce tylnej v. Sygn: : Nr LVIII (a. Z. G.).

20. Łac. II poł. XVIII w. $21 \times 17 \mathrm{~cm}$. K. 231. Opr. ptsk. wsp.

Theologia speculativa.

Inc.: k. 1: "Tractatus hic unus e capitalibus $\mathrm{X}$ desidero ac firmiter volo Deo opitulante:" k. $230 \mathrm{v}$.

${ }_{17}$ Ur. 2 VIII 1733 w Zamoścıu, do zak. wstąpił 1751, zm. 29 XI 1793 w Warszawıe. - CPP nr 145; Z. Gor 1 l $\mathrm{cki}$ : Notatk1 do historii kapucynów w Polsce; Rkps APK. Tom III s. 282; Mortuologium, jw., H. KOzersk a: Straty w zbıorze rekopisów Bibliotekı Unıwersytecksej w Warszawie $w$ czasie I I II wojny swiatowej. Warszawa $1960 \mathrm{nr} 427$; Catalogus scriptorum Ordinis Minorum S. Francise Capuccinorum ab anno 1747 usque ad annum 1852, sive appendix ad Bibliothecam scriptorum Capuccinorum a $P$ Beriardo Bononiensl elusdem ordinis editam anro 1747. Romae 1852 s. 36.

18 Ur. 6 XI 3.740, do zak. wstapił 1761, zm. 11 IX 1815 w Ostrogu. - CPP nr 282. 
Treść: „Tractatus VIII de gratia, iustificatione et merıto", k. 1-32v. "Tractatus IX de virtutibus theologicis et moralibus", k. 33-62v. "Tractatus $\mathrm{X}$ de incarnatione", k. $62 \mathrm{v}-89 \mathrm{v}$. "Tractatus XI de sacramentis in genere", k. 90-129v. „Tractatus XII de poenitentia“, k. 130-198. „Tractatus XIII de sacramentis extremae unctionis, ordinis et matrimonii", k. $198 \mathrm{v}-230 \mathrm{v}$.

Szkoła: prawdopodobnie studium domesticum polskich kapucynów. Karty niezapisane: 231. Wykresy: 220v, 221v, 222, 225.

Składki: 26. Kwaterniony od $6-26$ ale 13 bez $3 \mathrm{k}$. wydartych, 26 bez $2 \mathrm{k}$. Seksterniony 1, 3-5. Okternion 2.

Filigrany: Matka Boska $\mathrm{z}$ Dzıeciątkiem w otoku promieni, wyklejka frontowa. Jeździec na koniu, wyklejka tylna.

Oprawa w tekturę twardą szmacianą, sk. na grzbiecie cielęca barwiona na brązowo. Front grzbietu cały zamalowany farbą popielatą $z$ napisem tytułowym u góry: „Scrıpta theologica“. Okładka obciągnięta papıerem klajstrowym grzebieniowym na karagenie. Szycie na 2 taśmy.

Proweniencja: 1. Biblioteka OO. Kapucynów w Olesku. Pieczątka okrągła na k. 1, 142, 188. Sygn.: XIII 9.

2. Bibliateka: OO. Kapucynów. Kraków. Pieczątka okłrągła na odwrocie frontowej wyklejki i k. 231v.

21. Łac. II pot. XVIII w. $21 \times 17 \mathrm{~cm}$. K. 214. Opr. płsk. wsp.

"Cursus sacrosanctae theologiae seu disputationes in Quatuor Libros Sententiarum iuxta methodum et mentem Doctoris Mariani et Subtilis Duns Scoti".

Inc.: k. 2v: "Notandum 1 mo theologia speotata nominis $\mathrm{X}$ reverentissimae subiicio censurae et correct. correctioni. 8va iunii". k. $214 \mathrm{v}$.

Rękop1s został napisany prawdopodobnie przez jednego $z$ kapucynów - czeskich, działających na terenie Polskı. Wskazywałoby na to szereg elementów wspólnych gotykowı niemieckiemu. Numery paragrafów na marginesach. Glosy interlinearne. Tytuł grzbietowy ręcznie wykonany: „Scripta theologica scotistica".

Składkı: 34. Biniony 10, 12, 14, 16, 21, 24, 28, 30. Terniony 1, 2, 5-8, 17-20, 25, 26, 31-34. Kwarterniony 3, 9, 11, 13, 15, 22, 23, 27; 29. Okternion 4. Kustosze częściowo zachowane w prawym rogu górnego marginesu.

Filigrany: inicjały $J$ K, k. I; w kole w górnej częścı litera $N$, w dolnej inicjały J. K, w górze ponad kołem mały krzyżyk, poniżej koła data 1741 .

Oprawa w tekturę twardą. Grzbiet sk. cielęca barwiona na brązowo. Rożkı pergamınowe. Na tylnej okładce wewnątrz ślad tłoczonego ornamentu widocznego przez wyklejkę. Szycie na 3 sznurkı. Brzegi nakrapiane.

Proweniencja: 1. Biblioteka OO. Kapucynów w Olesku. Pieczątka okrągła na k. 1, 90, 184. Sygn.: XIII 3 .

2. Biblioteka OO. Kapucynów. Kraków. Pieczątka okrągła na k. 1v, 214v.

22. Łac. II pot. XVIII w. $17 \times 9.5 \mathrm{~cm}$. K. 186. Opr. brosz. wsp.

Theologia speculativa.

Inc.: k. 1: "Conclusio sexta. In sola visione non $\mathrm{X}$ non ordine enumerat tridientinum. Sessio $4 \%$. k. 186.

Karty niezapisane: $6, \quad 7,8, \quad 37, \quad 38,44-46,49 \mathrm{v}-52, \quad 53 \mathrm{v}-62, \quad 82-86$ 
$91 \mathrm{v}-102,108 \mathrm{v}-110,115,123,132 \mathrm{v}, 145 \mathrm{v}, 147,148 \mathrm{v}-150,166 \mathrm{v}-170,178 \mathrm{v}$, $183 \mathrm{v}-185,186 \mathrm{v}$.

Składki: 18. Terniony 11, 13, 15. Kwaterniony 1, 2, 9, 12, 14, 17, 18. Kwinternion 6 bez $2 \mathrm{k}$. Seksternion 10. Septentriony 3, 4, 16. Okterniony $5,7,8$.

Filigrany: fragment filigranu, dwie skrzyżowane gałęzie, nad nimi korona. $\mathrm{u}$ dołu inıcjały I G, k. 184, 185. Matka Boska z Dzıeciątkiem w koronach w otoku promienı, k. 147, Inicjały M I, k. 170; S, k. 149.

Oprawa $w$ tekturkę, obciągnıętą w całości papierem czerpanym, barwonym na brązowo techniką klajstrową (Pappband). Okładka frontowa i tylna uszkodzona i nadgryziona przez korniki. Szycie na 3 paski pergaminowe. Brzeg1 nakrapiane na brązowo.

Proweniencja: Biblioteka OO. Kapucynów. Kraków. Sygn: 9 B - 11: Nr LIX (o. Z. G.).

23. Łac. 1848. ¿3.5 X $19 \mathrm{~cm}$. K. 172. Opr. brosz. wsp.

"Conclusiones ex universia theologia. Selectae ex polemica ac speculativa cum obiectionibus".

Inc.: k. 1: „Q. Quid sit libertas? Rsp. Est immunitas a servitute $\mathrm{X}$ et ex meritis Christi nobis applicatis...". $\mathrm{k} .168 \mathrm{v}$.

Skryptor: o. Wojciech Patla ${ }^{19}$, kapucyn.

Reklamanty. Paginacja oryginalna: 159 , nlb. 4; 173, nlb 6. Karty niezapisane: 172. Spis treścl w dwóch kolumnach: k. $80 \mathrm{v}-82 \mathrm{v}, 169-171 \mathrm{v}$. Blok rękopısu składa sıę z siwego czerpanego prążkowanego papieru. Kursywa czytelna bez skrótów.

Składki: 22. Binion 1. Pozostałe kwaterniony lecz 2 † 2 k., 22 bez $2 \mathrm{k}$.

Filigrany: napis: G. Morau, na wyklejce frontowej, k. 86, 172.

Oprawa $w$ tekturę cienką, obciągnıętą w całości papierem (Pappband). Papier na zewnątrz czerpany marmurkowy na karagenie, na grzbiecie $u$ dołu obtargany. Szycie na 2 tasiemki.

Proweniencja: 1. O. Wojciech Patila.

2. Biblioteka OO. Kapucynów. Kraków. Pieczątka okrągła na frontowej wyklejce v, k. 80, 168v. Sygn.: $10 \mathrm{H}-9$; Nr LXIX (a. Z. G.).

24. Łac. $1880-1881$. $26.5 \times 20 \mathrm{~cm}$. S. 526+488. Opr. płsk. wsp.

"Tractatus de sacramentis. Tomus I. (Tytuł na 1 k. ochr.). "Tractatus dogmatico - scholasticus de sacramentis: Novae Legis explicatus in Collegio Cracoviensi Soc. Jesu. A. D. MDCCCLXXX-LXXXI". (Tytuł na $2 \mathrm{k}$. ochr.).

Inc.: s. 1: „1. Antequam particulares partes huius tractatus $\mathrm{X}$ et influxu dependentis a figura molecularum“. s. 488 .

Podręcznik teologiczny z wykładami o. Antoniego Langera ${ }^{20}$ T. J. Powlelany - litografia.

Składki: 61 kinionów. Kustosze liczbowe od I-IXXI.

19 Ur. 23 III 1818 w Krośnıe, do zak. wstąpił 1842, zm. 20 IX 1900 w Olesku. - Descriptio provinciae Galiciae. Rkps APK nr 3; Mortuologium, Jw.

${ }^{20}$ Ur. 8 VIII $1833 \mathrm{~W}$ Nysie, do zak. wstąpił w 18 r. zycla, zm. 8 IV $1902 \mathrm{w}$ Krakowie. Enc. Chetm. XXIII/XXIV 192. 
Oprawa w tekturę szarą grubą. Grzbiet z nabijanym oporkıem. Grzbiet oklejony płótnem. Dawnıj na grzbıecıe była sk. chagrain wiśniowa, dzisiaj zetlała. Grzbiet odpadl, resztki sk. na okładce I rogach. Kapitałka sztuczna naklejana. Brzeg czerwony polerowany. Wyklejka $z$ falcem płóciennym ze zwykłego papieru drzewnego.

Proweniencja: Biblioteka OO. Kapucynów. Kraków.

25. Eac. 1885. $20 \times 17 \mathrm{~cm}$. K. 271. Opr. brosz.

1. k. 1-80. "Tractatus I. De cneatione et peccato originali".

2. k. 81-175. "De unione humanae naturae cum Verbo seu de utriusque naturae in Christo nexu“.

3. k. 176-271. „De praisdestinatione et reprobatione“.

Skrypt z dogmatykı, wykładanej przez o. Wacława Titz'a ${ }^{21}$ T. J. w Kolegium OO. Jezuitów w Krakowie. Skryptor: kleryk kapucyński Damazy Kellar. Napisy na wyklejce: „Fr. Damasus capucinus, Cracovıae 1885“; „Expositıo R. P. Titz prof. theol. et phil“.

Proweniencja: 1. Fr. Damasus capucinus. 1885.

2. Biblioteka OO. Kapucynów. Kraków.

\section{TEOLOGIA MORALNA}

26. Eac., pol. 1650-1659. $20 \times 15 \mathrm{~cm} . K$. 321. Opr. ptpt. wsp.

"In Decalogum introductio".

Inc.: $\mathrm{k}$. 3: „Decalogus nomen graecum significat decem $\mathrm{X}$ kleinot pierwszy tylko Błogosławieństwo Boskie“, k. 321.

Treść: „In Decalogum introductio“, k. 1-116v. „Tractatus in praecepta 2dae tabulae Decalog1, de dilectione proximi“, k. 118-178v. „,Responsa theologiae moralis ad quaestiones de censuris“, k. 179-218v. "Resporsa theologiae moralis ad quaestiones de statibus hominum", k. 219-246. „Tractatus de sacramentis", k. 247-289v. "Compendium theologicae veritatis in aliquot libros digestum", k. 290-295. "Disputatıones controversiarum de ecclesia militante", k. 296-313v. "Responsa theologiae moralıs de statu parochorum", k. 314-321. Ponadto $w$ języku polskım fragmenty rozmyślań 1 kazań znajdują się na k. 14v, 15, 161 (fragment pıeśnı o cierpiącym Chrystusie), 218, 231, 232-234, 295, 299v-301v, 313，321. K. 32; "Zalewsky jusz wszyscy...“.

Szkoła: Arcybiskupie Semmarium w Tymawic. Profesorowie: o. Demsterius T. J., o. Jan Nadassy ${ }^{29}$ T. J. Skryptor: o. Albert.

Tytuł na k. $1 \mathrm{w}$ ozdoinej winietce $\mathrm{z}$ dwoma anıołamı w górze podtrzymującymi tablıcę z unicjałamı: IHS. Wokoło tytułowego owalu inicjały: L.K.S. E. Tytuł na k. 2 rubrykowany, Rubrykowane niektóre podtytuły 1 inicjały w części rękopısu. Margines boczny i dolny w częścı bloku rękopisu dość szeroki. Reklamanty. Bogate glosy marginalne. Rękopis wykonany trzema rękamı. Pierwsza część rękopisu od k. 1 -116 jest najstarsza 1 po-

21 Ur. 7 XII 1830, do zak. wstąpil 1852, zm. 4 IV 1914 w Dzuedzıcach. - Catalogus bievis Prov Galicianae S. J. 1852-1914.

2z Ur. 13 I 1613 w Tymawie, do zak. wstapil 1633, zm. 3 III 1679 w Wiednı. Jeden z wybitnych pisarzy ascetycznych XVII w. - B acker-Som mervogel V 1520-1537, Enc. Chetm. XXVII/XXVIII 286-287; Enc. Now, XV 388-389; Ks. J. B r own, Jw. s. $469,488$. L. Ko c h : Jesuitenlexicon. Paderborn 1934 s. 1269. 
chodzl prawdopodobnie sprzed 1650 r. Inskrypcje: k. 118: „Sub R. Pre Demsterio Soc1etatis Jesu Tyrnaviae 1659“; k. 217v: „Sub R. P. Joanne Nadaszy 9 april. finitum anno 1650“; k. 230v: „Sub R. P. Joanne Nadasze s. moral theol. doctore elusdem professore ordinario. In AA. Academia et Universitate conscripti".

Składki: 49, 2, 14, 27, po $2 \mathrm{k}$. Biniony 3-13, 15-26, 36. Ternion 28 bez 2 k. Kwaterniony 29, 35, 37, 45, 46 bez $1 \mathrm{k}$, 47, 48. Kwinterniony 33, 42. Seksterniony $1+1 \mathrm{k}$., $30,31,32,34$ bez $5 \mathrm{k}$. wyrwanych, 38,39 bez $2 \mathrm{k}$, $41,43,44,49$ bez $2 \mathrm{k}$. Okternion 40.

Filigrany: tarcza herbowa $z$ orłem, k. 32. Zdobnik, k. 202, 203. Prawdopodobnie znak fabryczny $z$ inicjałaml ponad rysunkiem $G P$, k. 217 .

Oprawa półmiękka. Grzbiet pokryty szarym płótnem. Okładki obciągnięte makulaturą $z$ wczesrego starodruku wykonanego szwabachą $z$ kolorowanymi inicjałami; w czasie późniejszym wzmocniona na grzbiecie makulaturą z kalendarza polskiego wczesnego oraz dwoma paskami papieru klajstrowego. Szycie na 3 paski pergaminowe.

Proweniencja: 1. R. P. Albertus, k. 230v.

2. „Ex libris a Clariss, et Excellentissimo Domino IM. Aegidio Stephano Wadowski philos. doctore et proffess, collega minore eiusdem Collegii Praeposito, Contubernii Jagelloniani electo seniore donatis et applicatis Bibliothecae PP. Capucinorum Cracoviensium. Anno Dni 1721 in ianuario". Napis na karcie tytułowej.

3. Biblioteka OO. Kapucynów. Kraków. Pieczątka okrągła na k. 2v, 321v. Sygn.: $9 \mathrm{D}-7$, na odwrocie frontowej okładki.

27. Łac., pol. II pot. XVII w. $19 \times 15.5 \mathrm{~cm}$. K. 74. Opr. perg. wsp. „Praxis confessionis. Ea quae ad praxim confessionis spectant sunt triplicia: quaedam ante confessionem, quaedam in ipsa confesione et quaedam post confessionem adhibentur".

Inc.: k. 2: „Requlisita confessionem antecedentia sunt duplicia X ut sunt mendiacia, verba otiosa etc.", k. $72 \mathrm{v}$.

Rękopıs Kazımierza Weysse ${ }^{23}$, kanonika kieleckiego i kapelana biskupa krakowskıego K. Eubieńskiego. Reklamanty. Karty niezapisane: 1, 73, 74. Kolumny tekstowe ujęte $w$ pojedynczą ramkę. Tytuly rozdziałów i podrozdziałów wykonane pismem w formie liter drukowanych. Ozdobny inicjał w jednym kolorze na k. 2. Na każdej karcie w górnej częścı nad ramką widoczny krzyżyk. Nieliczne glosy marginalne.

Składk1: 18. Ternion 1. Pozostale biniony.

Filigrany: tarcza herbowa $\mathrm{z}$ koroną 1 orłem dwugłowym $\mathrm{w}$ pośrodku, k. 3, 8. Na tylnej wyklejce miecz lub krzyż.

Oprawa w tekturę, obcı̨̨gnıęta w całoścı pergamınem. Ślady malowanı grzbietu. W grzbiecie ślady zaatakowania przez korniki. Szycie na 2 paski perg. przeciągnıęte przez grzbiet. Slady dwóch par rzemyków do wiązania.

Proweniencja: 1. Ks. Kazimierz Weysse. „Ex libris Casimiri Weysse Can. Kielcensis capellani ad Celsissimum Principem Episcopum Cracoviensem 1710". Napis na k. 1v.

2. „... donatis et applicatis Bibliothecae PP. Cap. Conventus Crac. pro cuius

${ }^{23}$ Zm. 23 II 1738 w Krakowle, pochowany w krypcie Domku Loretańskiego OO. Kapucynów. Mortuologium, jw. zalicza go do wybitnych dobrodzlejów klasztoru. Bogatą bibliotekę ofiarowal klasztorowi krakowskiemu. - Por. Historia Conventus nostrı Capucinorum Cracoviensium. Rkps AKK s. 60-61. 
anima benigne lector dicat Ave Maria". Dalszy ciąg napisu z k. 1v, wykonany innym atrumentem i inną ręką. Sygn.: $14 \mathrm{E}-23$ na k. 1 .

28. Łac. II pot. XVII w. $19.5 \times 15 \mathrm{~cm}$. K. 328. Opr. brosz. wsp.

Theologia moralis polemica.

Inc.: k. 1: „Post explicata ela omnia quae $\mathrm{X}$ et hic iam tota de sacramentis materia finita est", k. 328v.

Treść: „De sacramentis in particulari et imprimis de baptismo et confirmatione", k. 1-44. "Tractatus 3 de sacramentis eucharistiae", k. 45-108. "Tractatus IV de sacramento poenitentiae“, k. 109-187v. "Tractatus Vtus, de clavibus ecclesiae seu censuris“, k. 189-256v. „Tractatus VItus, de sacramento ordinis", k. 256v--280v. "Tractatus VIIus, de sacramento matrimonii", k. 281-321. ,Tractatus de sacramento extremae unction1s“, k. 321-328v.

Reklamanty. Karty niezapisane: 44v, 108v, 188. Slady zawilgocenia w środku bloku rękopisu od strony brzegu bocznego.

Składki: 29. Binion 17. Ternıon 25. Kwaterniony 4, 10. Septentrion 24. Pozostałe sekstemiony.

Filigrany: orzel w koronie z jabłkıem i berłem, k. 6, 7. Tarcza herbowa z. koroną, w polu orzel lub gryf, k. 108, 109.

Oprawa w tekturę. Grzbiet obciągnięty papierem czerpanym jasnym i okładki czerpanym barwionym na czerwono lecz już wyblakły. Grzbiet uszkodzony $w$ górnej i dolnej części, papier zetlały. $\mathrm{Na}$ frontowej i tylnej okładce odcıśnięte ręcznym filetem linie proste $w$ formı ramki zewnętrznej I wewnętrznej połączonej przekątniami. W narożnikach zwierciadła między ramkamı ręczny stempel z motywami kwiatów. W pośrodku stempel w kształcıe wianuszka z liści. Szycie na 3 sznurki. Brzegı nakrapıane na czerwono.

Proweniencja: Biblioteka OO. Kapucynów. Kraków. Sygn.: 9 C-41; Nr XLIV (o. Z. G.).

29. Eac. 1738-1739. $20.5 \times 16.5 \mathrm{~cm}$. K. 242. Opr. ptsk. wsp.

"Regulae actuum humanorum seu tractatus materiarum morialium ad dirigendam propriam proximique conscientiam apprime summe necessariam. In gratiam PP. Studentium Seraphico Capucinorum a F. Canstantio Svidnicensi eiusdem ordinis sacerdote, Provinciae Bohemiae professo succincte compilati".

Inc.: k. $2 \mathrm{v}$ : „Dividemus praesentem tractatum in $\mathbf{5}$ disputationes $\mathrm{X}$ ita se poterant obligare ad maritalem cohabitationem", k. 236.

Szkoła: Studium domesticum kapucynów w Warszawie. Lektor: o. Konstanty ze Swidnicy, Slązak, należący do czeskiej prowincji kapucynów. Skryptor: o. Klemens Grygierski ${ }^{24}$.

Paginacja oryginalna rekkopisu: $472, \mathrm{knlb}$. 9. Karty niezapisane: 157-159, 236v, 237-239, 242v, 243-246. „Index generalis“", k. 240-242. Zakładki z drukowanym tekstem: ,Suscepit Communionem Paschalem in insigni Ecclesia Collegiata et Parochiali Varsaviensı S. Joannis Baptistae. Anno 1740";

24 Ur. 30 IX 1713 w Krakowe, do zak. wstąpil 1729, zm. 29 III 1765 w Olesku. Kapelan króla stanisława Leszczyńskıego w Luneville. - Gorlicki, jw. s. 65; O. A. Wojnar: Rocz. Kapucynów Prow. krak. 1950 s. 71. Nie mylić Klemensa z drugím kapucynem o tym samym nazwisku, który wstąpil do zak. 1747 a $\mathrm{zm}$. 1789. Por. CPP nr 34, 115 
„Modlitwa do S.O. Franciszka“" z tych czasów. Na wyklejce frontowej okładki napis inną ręką: "Theologia haec scripta est a R.P. Clemente a Cracovia famosi concionatoris, consultoris, guardiani Lublinensis, postea concionatoris regis Stanislar [Leszczyński] Lunevillae in Lotharingia. Deinde reditus, guardiani Leopoliensi et in praesıdentia Kutkorıensi, mortui Olesco". $\mathrm{Na}$ tylnej wyklejce nota: „Haec theologia dictata est a R. Patre Constantio Sv1dnicense amantissimo lectore nostro in anno 1738 die autem 29 iulii, finivimus: autem in anno 1739 die 13 decembrıs. Examinatores erant: Adm. Reverendus Pater Liborius Graslicensis praeses pro tune commissarius generalis per Poloniam. 2dus Ad. Venerandus Pater Achatius Pragensis guardianus actual:s Conventus Varsaviensis. 3tıus. Adm. Venerandus Pater Emanuel, concionator ad S. Benonem. 4tus. Adm. Venerandus Pater Constantius Svidnicensis lector theologiae. Finito examine erant duae disputationes publicae. 1mam defendit Pater Constantinus a Varsavia. Oppugnaverunt: Rndi Dni Bartholomitae. 2dam defendit Pater Valentinus Ressoliensis. Oppugnates: Reverendus $\mathrm{Pa}$ ter Paulanus Collegii Romani de Propaganda Fide professor theologiae. 2dus Adm. R. Pater Solcietatis Jesu Moridoni doctor theologiae. In praesentia magnatum, episcoporum, religiosorum. Inde omnia peracta sunt cum laude divina et maximo honore religionis Capucinorum. Cura et labore nostri amantissimi lectoris. Studentes: Pater Nicolaus Siennensis, P. Venceslaus Varsaviensis, Pater Constantinus Varsaviensis, P. Clemens Cracoviensis, Pater Valentinus Rossoliensis, P. Justinus Leopoliensis. Scriptor huius theologiae fuit P. Clemens Capuci[nus] indignus".

Składki: 25. Kwaterniony od 1-11, lecz 1 bez $1 \mathrm{k}$., 25 bez $2 \mathrm{k}$. Kwinternion 24 bez $2 \mathrm{k}$. Pozostałe seksterniony.

Filıgrany: nazwa zapewne miejscowoścı Sorau z irrzyżykıem w górze, k. 97. Medalion z Matką Boską z Dzieciątkiem w otoku promieni, wspartej o półksiężyc, z boku lilie, u dołu napis $\mathrm{S}$ Marıa, k. 236, 237. Na wyklejkach ślad filigranu $z$ inicjałami M S.

Oprawa twarda w tekturę szarą szmacianą. Grzbiet i rogi sk. ciejęca barwiona na brązowo. Okładki obciągnięte klajstrowym brązowym papierem czerpanym. Szycie na 2 sznurkı. Brzegı nakrapıane.

Pronveniencja: 1. O. Klemens Grygielski, kapucyn.

2. Biblioteka OO. Kapucynów w Olesku. Pieczątka okrągła na k. 1, 134, 227. Sygn.: XIII 22.

3. Biblioteka OO. Kapucynów. Kraków. Pieczątka okrągła na wyklejce frontowej okładki i k. 236v.

30. Łac. 1741-1743. $20 \times 16.5 \mathrm{~cm}$. K. 176. Opr. płsk. wsp.

„Universa theologia scotistica“".

Inc.: $\mathrm{k} .1$ : ,In humana protoparentum nostrorum in pasteros $\mathrm{X}$ iustificatione et merito dicta sint satis et cedant...", k. 176.

Szkoła: Studium domesticum kapucynów we Lwowie. Lektor: o. Remigiusz z Rychnowa ${ }^{25}$, Czech. Skryptor: o. Romuald Jakubowicz ${ }^{26}$ ze Lwowa.

Reklamanty. Karty niezapisane: 116, 154. Nieliczne glosy margınalne.

${ }_{25}$ Do zak. wstąpił $30 \mathrm{IX} 1722$, zm. na stanowisku gwardiana w Opocznie 15 IX $1759 .-$ Syllabus, JW.

${ }^{26}$ Ur. 27 IX 1711, do zak. Wstąpil 1755, zm. 10 VIr 1774 w Ostrogu. - CPP nr 45; Mortuologium, JW.; Cathalogus Patrum et Fratrum Minorum Capucinorum Provinciae Polonae anno MDCCLV. Rkps Archiwum Prowancji Czeskiej Kapucynów w Pradze. 
Karty w górnym marginesie znaczone krzyżykıem. Inskrypcje: frontowa wyklejka: „Inchoavi theologiam moralem scilicet tractatum 1mum de beat1tudine et actibus humanis Leopoli die 27 ulii 17410". Poniżej inną ręką: "Haec theologia est scripta a P. Romualdo Capucino pro tunc studente theolograe quı ıpsam habebit recordor animae eius"; k. 58v: „Ima februarii finıvi iractatum de legibus. AC 1742"; k. 117: ,Die 20 lunii a. 1742 incepi sub Rdo P. Remigio L."; k. 176: „Finlvi hunc tractatum Leopolı sub Rdo Patre Remig1o lectore sacrae theologiae. Anno 1743 die 12 februarii".

Składki: 18. Biniony $18+1 \mathrm{k}, 12-16$. Kwaterniony 5, 11, 17. Kwinterniony $1,3,7,9$. Septentriony $2,4,6,8,10$ bez $2 \mathrm{k}$.

Filigrany: ınıcjał M S, k. 173. Matka Boska z Dzieciątkıem w otoku promieni, k. 171, 176.

Oprawa w tekturę szarą. Grzbiet i rog1 obciągnięte sk. clelęcą barwioną na brązowo, a okładki papierem czerpanym kolorowanym również na brązowo. Szycie na 2 wiezy. Brzegi nakrapiane na niebiesko.

Proweniencja: 1. O. Romuald, kapucyn. Napis na wyklejce frontowej.

2. „A. V.P. Romualdus scripsit diligentissime. Deus insum coronet pro laboribus. Corona gloriae praecatur ipsi Fr. indignus A[egidius] qui ea usus est". Napis na k. $176 \mathrm{v}$.

Bibioteka OO. Kapucynów. Kraków. Pieczątka okrągła na odwracie frontowej wyklejki i k. 176v. Sygn: $\mathrm{Nr}$ XXXIII (O. Z. G.).

31. Łac. 1741-1743. $20 \times 16.5 \mathrm{~cm}$. K. 189. Opr. ptsk. wsp.

„Universa theologia scotistica ${ }^{66}$.

Inc.: k. 1: „In humana protoparentum nostrorum in posteros $\mathrm{X}$ iustificartione et merito dicta sint satis et cedant...", k. 189.

Szkoła: Studium domesticum kapucynów we Lwowie. Lektor: o. Remigiusz z Rychnova, Czech.

Reklamanty. Karty niezapısane: 11, 12, 124, 166v, 189v. Rysunki: k. 140v: ,,arbor consanguinitatis"; k. 141: ,arbor affinitatis“; k. 141v: ,arbor cognat,1onis spiritualıs" 1 ,,arbor consanguinitatis legalıs“. Nalepione obrazkı na k. 12 św. Bonifacego, na k. $166 \mathrm{v}$ bł. Jana z Dukli. Na wyklejce notatka: „Rkps zakupiony za pośrednictwem dra Ludwika Gocla w antykwarni w Bydgoszczy“.

Składki: 27. 17, 20 po $2 \mathrm{k}$. Binion 1. Terniony $4,6,7,8,10,12,14,16$, 19, 21. Kwaterniony 2, 22, 23, 24 bez $4 \mathrm{k}$. wydartych, 25, 26, 27 bez $1 \mathrm{k}$. Kwinterniony $3,5,9,11,13,15,18$. Kustosze literowe w górnym marginesie zachowane częściowo.

Filıgrany: data 1740 przeplata sıę na przemian z kıelichem z hostią, dalej ze słońcem, k. 4, 20, 76, 164, 169.

Oprawa jak pod nr 29.

Proweniencja: 1. „Bibliotheca PP. Capucinorum Ostrogiensium“. Napis na wyklejce frontowej. Sygn.: E 93.

2. Biblioteka OO. Kapucynów. Kraków.

32. Łac. 1742-1743. $21 \times 16.5 \mathrm{~cm}$. K. 583. Opr. ptsk. wsp.

,Sacrosancta theologia scoltistica in sano scripturae sacrae sensu et conciliis generalibus, in sanctis patribus, et in sententia Scoti fundata. Quae ab A. V. P. Prospero Neostadiensi Capucino s. sanctae theologiae lectore in Coenobio Hedvigiano inchoatur anno quo R. P. Hugolino Ziatecensi Custodi Silesiae. praecelsa delegatur cura totius Provinciae. 
Ista legas heu munde solers, attractus in astra. Assurge esto tuus fessus honorque Theos".

Inc.: $\mathrm{k}$. 3: „Cum plerique scholastici scriptores qui $\mathrm{X}$ et hac de virtutibus theologicis dicta cedant...", k. 582v.

Szkoła: Studium domesticum kapucynów we Wrocławiu i w Pradze na Hradczynie. Lektor: o. Prosper Neostadiensis ${ }^{27}$ (Wrocław); o. Felicissimus Neorodiensis ${ }^{23}$ (Praga).

Karty nezapisane: $1 \mathrm{v}, 28 \mathrm{v}, 368,583$. Dukt pisma kukowaty $\mathrm{z}$ elementami gotyku niemieckiego. Wstawka z rysunkami: k. 345: "arbor consanguinitatis" 1 , ,cognationıs legalis". Wykresy na powyższe tematy na k. 519 i 520 . Kolofon na k. 582: „Praga in Hradschin die 30 ianuariı anno Dni 1743 sub A.V.P. Felicissimo Neorodensi lectore ss. theologiae".

Składkı: 49.49 ma $2 \mathrm{k}$. Binion 43. Kwaterniony 2, 3, 45. Okterniony 19, 35. 36, 47. 37 ma $20 \mathrm{k}$. Pozostałe seksternıony. W częścı składek kustosze liczbowe: $1-28 ; 1-5 ; 1-5$.

Filigrany: zdobnik na wyklejce frontowej. Tarcza herbowa $z$ korona 1 skrzyżowanymi pastorałem $1 \mathrm{krzyżem}, \mathrm{k}$. 1 . Dwie postacıe $\mathrm{z}$ rośliną $w$ środku 1 napisem poniżej: Marocae Pappıaer, $k .368$.

Oprawa $\mathrm{w}$ tekturę półtwardą. Grzbiet 1 rogı obciągnięte sk. cielęca. Okladki obciągnięte papierem czerpanym barwıonym na brązowo. Grzbiet wzmocniony szarym płótnem. Szycie na 3 więzy. Kapitałka wyszywana białoniebieska

Proweniencja: „Pro Bibliotheca P.P. Capucinorum Cracoviae". Napis na k. tytulowej. Sygn.: $10 \mathrm{H}-17$; Nr LIII (o. Z. (x.). Pieczątka okrągła: Biblioteka OO. Kapucynów. Knaków, na k. 1v, 88v, 583.

33. Łac. 1746(?). $21.5 \times 16.5 \mathrm{~cm}$. K. 168. Opr. brosz. wsp.

„Manuscripta theologiae moralis de actibus humanis a P. Prothasio Paschwicensi“".

Inc.: k. 1: „Quoniam a Deo Authore et Conditore suo homo X difficultas comparandi scientias debitas. 3. inconstant", k. 168v.

Treść: „Traictatus IIItius de actibus humanis", k. 1-82v; ,Tractatus IVtus de legibus", k. 83-126v; ,Tractatus Vtus de peccatis", k. 127-168v.

Skrypt teologiczny napisany przez o. Protazego Hudelka ${ }^{29}$, Slązaka. Na marginesach numery paragrafów. Wklejka: k. 52a. Kodeks bardzo zniszczony. Z okładki tylnej i k. 127 i 128 pozostały tylko strzępy. Ostatnie dwie karty mocno nadwerężone.

Składki· 15 seksternionów $\mathrm{z}$ wyjątkiem 15 bınıonu. Kustosze liczbowe od I-XIV.

Filigrany: w pierwszej połowie rękopisu występuje w górnej lewej części k. fragment filigranu z partią napisu trudnego do odczytanıa. Lilıa, k. 133, 134. Inicjały EL, k. 135,136

Oprawa broszurowa. Obciagnięta papierem czerpanym barwionym na żółto. Szycie na 3 sznurki.

27 Do zak. wstąpił 12 VII 1725, $2 \mathrm{~m}$. we Wrockawiu 23 IX 1775. - Syllabus, jw.

2a Do zak. wstąpił 5 XI 1722, zm. w Nysie 27 VI 1764. - Syllabus, jw.

29 Ur. 3 XII 1721, do zak. wstąpil 1743, zm. 24 VI 1788 w Konstantynowie. - CPP nr 85; Mortuologjum, jw. 
Proweniencja: 1. O. Protazy Hudelka.

2. Biblioteka OO. Kapucynów w Olesku. Pieczątka okrągła na k. 1, 22, 105, 163. Sygn.: XIII 8.

3. Biblioteka OO. Kapucynów. Kraków.

34. Łac. '1749. $17 \times 10.5 \mathrm{~cm}$. K. 182. Opr. sk. wsp.

„Compendium theologiae moralis conscriptum a Patre Sancto Iglaviense ${ }^{30}$ Ord. Min. [Capucinorum] s. theologiae studioso. Anno Dni $1749(?)^{\prime \prime}$.

Inc.: k. 1: „Quae[stior]. Quid est actus humanus X vir ut uxor mea copulam offert", k. 182.

Kodeks wyszedł ze studium domesticum czeskich kapucynów i napisany został przez Czecha. O tym świadczą elementy gotyku niemieckiego widoczne w rękopisie. Foliacja oryginalna: 166, nlb 2, 15. Na końcu kilka składek wycięto już w XX w. Karty niezapisane: 160v, 161v, 162v, 163r, 182v. Karty wklejone z rysunkami: k. 170: ,arbor consanguinitatis"; k. 171: „,ognat o legalis"; k. 180: ,,arbor affin.tatis"; k. 181: "arbor cognationis spiritualis".

Składkı: 23. Biniony 1, 21. Pozostałe kwaternıony lecz $21+1 \mathrm{k}$.

Filigrany: fragment niezidentyfikowanego filigranu $w$ lewym górnym rogu karty.

Oprawa w deskę z kantami ścinanymı do środka. Grzbiet i okładki obciągnięte sk. cıelęcą barwioną na brązowo. Rameczka z linii prostych odciśnıętych na ciemno wokół okładek. Szycie na 3 więzy. Resztki rzemyków do zapinania na gwoździe. Kapıtałka szyta jedwabna, białonıebieska. Brzegi nakrapiane farbą niebıeską 1 czerwoną.

Proweniencja: 1. P. Sanctus Iglaviensis.

2. „Applicat Bibliathecae PP. Capuc[inorum] Conv. Cracov[iensis]. Napis na frontowej wyklejce. Sygn.: $9 \mathrm{C}-6$; $\mathrm{Nr}$ XIIX (o. Z. G.).

35. Łac. 1758. $17 \times 9.5 \mathrm{~cm} . K, 70$. Opr. brosz. wsp.

„Selecta breviter ex theologia morali. 1758. Ad usum P. Simoni a Lipnica Capucini“".

Inc.: k. 2: „Abigeatu's est iniusta acceptio gregis alieni $\mathrm{X}$ ad aedificationem et fidelium dispensationem", k. 65.

Treść: kompendium zawiera definicje $\mathrm{z}$ teologii moralnej ułożone $\mathrm{w}$ porządku alfabetycznym, k. 1-28v; „De communicatione privilegiorum", ,Series privilegiorum", k. $34-41 \mathrm{v}$; skrót teologii moralnej, k. 42-65.

Szkoła: Studium domesticum kapucynów w Olesku. Lektor: o. Antonin a Żżanne ${ }^{31}$. Skryptor: o. Szymon Sikorski. Karty niezapisane: $29-33,65 \mathrm{v}-70$ Wiele kart luźnych.

so Do zak. wstąpił 6 X 1722, zm. 17 IX 1768 w Pradze na Hradczyme. - Syllabus, Jw.

31 Ur. 4 III 1728, do zak. wstąpir 1748, zm. 3 VIII 1793 w Warszawıe. Plerwszy prowincjał narodowości polskıej. Godność biskupıą otrzymał w r. 1768. - CPP nr 117; Bullarıum Ordinıs Fratrum Min. Capuccinorum. T. 1-7. Romae 1740-1752. T. 8-10. Oeniponte 1883-1884. Regestum zob. Analecta OMCap. T. B-13 (1692-1897). T. 8 s. 403; Lexicon capuccinum. Romae 1951 szp. 1424; Ks. J. Korytkow ki : Pralaci 1 kanonıcy kat. metr. gnieźnieŕskiej. Gniezno 1883. T. 3 s. 295; O. Z. Gorlucki, Jw. s. 68-71; Estr. XII 177; Ks. Z. Obertyńskı: Das Werden und Wirken der polnischen Kapuzinerprovinz vor der Teilung des Reiches (16801795). Collect. francisc: T. 8: 1938 z. 2/4 s. $378-380$. 
Składki: 9. Terniony $5+1 \mathrm{k} ., 9$. Pozostałe kwaterniony lecz $1+1 \mathrm{k} ., 8$ bez $1 \mathrm{k}$. Kustosze liczbowe od I-VIII.

Filigrany: Matka Boska z Dzıeciątkiem w koronach w owalu promieni, k. 33. Inicjały pod tarczą herbową A H T, k. 5, 6 .

Oprawa broszurowà. Obciągnięta papierem czerpanym barwionym na niebiesko. Brak tylnej okładki i grzbietu. Szycie na 2 rzemyki.

Proweniencja: 1 O. Szymon Siknorski.

2. Biblioteka OO. Kapucynów. Kraków, Sygn: 9 B-12 na okładce frontowej.

36. Łac. 1758. $20 \times 17 \mathrm{~cm}$. K. 265. Opr. ptsk. wsp.

,Theologia morralis complectens sex tractatus monales, nempe: de actibus humanis, de legibus, de iure et iustitia, de peccatis, de sacriamentis, de poenitentia et matrimonito nec non prologomenalia et de beatitudine. Dictata ab A. V. Patre Sigismundo Oppoliensi 32 lectore dignissimo. Scripta a Fratre Ladislao Prissinensi ${ }^{33}$ Capucino anno Dni 1758vo. Lublini ad SS. Petrum et Paulum".

Inc.: k. 3v: „Cum mensura facultatis cuiusque sit $\mathrm{X}$ exercuissent. Copia authentica 652 dae de sacramentis", k. $265 \mathrm{v}$.

Szkola: Studium domestıcum kapucynów w Lublınıe.

Reklamanty. Karty niezapisane: $1 \mathrm{v}, 62 \mathrm{v}, 63,64 . \mathrm{Na}$ marginesach numery paragrafów. K. 259 to wstawka z rysunkiem ,arbor affinitatis" o wymiarach $41 \times 32 \mathrm{~cm}$.

Składki: 33. Kwinterniony 16, 20. Pozostałe kwaterniony, lecz 8 bez $1 \mathrm{k}$, a 33 posiada tylko $4 \mathrm{k}$.

Filigrany: tarcza herbowa z korona, k. 1. Matka Boska z Dzıecıątkıem w otoku promeni i napisem $z$ boku MAS, k. 259.

Oprawa półtwarda. Grzbiet sk. clelęca barwiona na brązowo. Grzblet zamalowany farbą olejną. Okładkı obciągnięte papierem ręcznym klajstrowym w kolorze brazzowym. Szycie na 3 sznurlsi.

Proweniencja: 1. O. Władysław Puciata.

2. Biblioteka OO. Kapucynów w Olesku. Pieczątka okrągła na k. 1, 58, 148. Sygn: XII 45.

Biblioteka OO. Kapucynów. Kraków. Pieczątka okrągła na k. 1v i na odwrocie tylnej wyklejki.

37. Łac. 1766. $22.5 \times 18.5 \mathrm{~cm} . K .275$. Opr. brosz. wsp.

„Arcana ss. theologiae universae iuxta mentem Subtilis Marianique Docitoris Joannis Duns Scoti methodo scholastica elucidata ab AVP. Simone a Lipnica p.t. lectore actuali s. theologiae. Anno Dni 1766 9bris die. Fr. Vailentini Capucini“.

Inc.: k. 2: „Hanc disputationem prologomenalem paucis absolvimus $\mathrm{X}$ et retractionis opprobrium non vere... omnia cedant...", k. $274 \mathrm{v}$.

Szkoła: Studium domesticum kapucynów w Krakowie. Lektor: o. Szymon Sikorski. Skryptor: o. Walenty Wróblewski.

s2 Ur. 2 VIII 1719 W Opolu, do zak. wstąpil 1742, zm. 25 IV 1793 w warszawie. - CPP nr 72 ; O. Z. Gor $11 \mathrm{ck}$, Jw. s. 311 .

${ }^{33}$ Ur. 30 III 1732, do zak. wstąpil 1753, zm. 25 I 1793 w Dunajowlcach. - CPP nr 174: Mortuologium, Jw. 
Napis tytułowy ozdobny w podwójnej ramce margınesowej. Do k. 104 papıer o odcıeniu białym dalej o odcienıu brązowym. Karty niezapısane: 275. Numery paragrafów na marginesach. Bardzo rzadkie glosy marginalne. Rysunkı: k. 267: „cognatıo spıritualıs“; k. 267v: „,ognatıo legalıs“; k. 268: "arbor consanguinitatis" i ,arbor affinitatis".

Składk1: 35 kwaternıonów. 21 bez $4 \mathrm{k}$. wyciętych i 35 bez $1 \mathrm{k}$.

Filigrany: rycerz stojący $\mathrm{z}$ mieczem $\mathrm{w}$ prawej ręce 1 szyszakiem $\mathrm{w}$ lewej, ponıżej inicjały I H K, K. 4, 5. Satyr z laską (?), k. 269, 275. Nazwa Troppau (Opawa), k. 267.

Oprawa w tekturę szarą szmacianą, obclągniętą papierem czerpanym, kolorowanym na sinozielono. Szycie na 3 sznurki.

Proweniencja: 1. O. Walenty Wróblewski.

2. Biblioteka: OO. Kapucynów. Kraków. Pieczątka okrągła na adwrocie wykiejki frontowej $\mathrm{i}$ k. $274 \mathrm{v}$. Sygn.: 9 D-27: Nr LXVIII (O. Z. G.).

Uwagi: por. Helena $\mathrm{K}$ oz e rs k a: Straty $w$ zbiorze rękopisów Biblioteki Uniwersyteckiej $w$ Warszawie $w$ czasie I $i$ II wojny światowej. Warszawa 1960 poz. 427.

38. Eac. 1769-1772. $23 \times 19 \mathrm{~cm}$. K. 61. Opr. sk. wsp.

„Promptuiarium resolutionum seu theologia moralis compendiata brevi et clara methodo iuxta suos canones et novissima decreta Summorum Pontificum ac probabilissimos authores succincte resolvens omnes materias morales et praecipue $R$. P. Reiffenstuel, R. P. Wigandt, R. P. Antoine et R. P. Thoma ex Charmes Capucinum ac alia notabilia scripta. Authore vero huius promptuarii P. Pio de Cracovia Capucino. Anno Dni 1772 ".

Inc.: k. 3: „N. 1. Actiones quae procedunt ab homine aliae $\mathrm{X}$ tamquam Sedis Apostoliciae delegati tridentinis 25 C. 5 de reg.", k. 61v.

Szkoła: Studium domestıcum kapucynów w Sędziszowie. Lektor: o. Pius Manieck1 ${ }^{34}$.

Reklamanty. Wklejkı: k. 15a, 12a. Glosy marginalne $\mathrm{i}$ interlinerne. Rysunk1: k. 50: ,arbor consanguinitatıs"; k. 51: ,arbor cognationis spiritualis“. Inskrypcja: k. 3: "Jesus et Maria sınt mecum in via. Labor Sędzıszoviensis anno Dni 1769 die 5ta iunir".

Składki: 8 kwaternionów, 8 bez $3 \mathrm{k}$.

Filigrany: tarcza herbowa $z$ korona i napisem $u$ dołu: Vanderley, k. 1, 2.

Oprawa w tekturę szara obcıągniętą w całą sk. cielęcą. Przy więzach na grzbiecie odcıśnięte na sucho grube linie oraz na okładkach ramka biegnąca wokół, o dwóch linıach. Szycie na 3 więzy.

Proweniencja: 1. O. Pius Maniecki.

2. O. Klemens Grygielsk1. „Post mortem Adm. Vidi Patris Pii actualis guardianı Zaknoczymensis concessum est mihi Fri Clementino Capucino ad simplicem usum. Hoc elabioratum Promptuarium resolutionum. Ad M. D. Gloriam 1773 die 18 februarii Varsaviae".

3. Biblioteka OO. Kapucynów. Kraków. Pieczatka okragła na k. 1v, 61v; owalna na frontowej wyklejce $\mathrm{i} k$. 2. Sygn.: $22 \mathrm{~F}-136 ; 14 \mathrm{Y}-23$; Nr LXXXIV (o. Z. G.).

39. Łac. 1772, $15 \times 9 \mathrm{~cm}$. K. 85. Opr. sk. wsp.

Universae theologiae in duas partes divisae hoc est in moralem et

Ur, 19 IV 1738, do zak. Wstąpil 1753, zm. 17 II 1774 w Warszawle. - CPP nr 170;

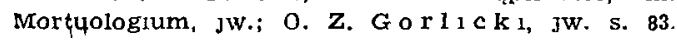


speculativam collectae compendium. Facilitati eorum, quae memoriae mandata sunt reminiscendi accomodatum conscriptumque anno Domini $1772^{\prime \prime}$.

Inc.: k. 2: „1mo. Theologiae secundum nominis aethimologiam ex graeco desumptam $X$ haec pro interim' sufficiant et cedant...", k. 81v.

Reklamanty. Karty niezapisane: 1v, 82-85.

Składkı: 7 seksternionów.

Filigrany: na frontowej wyklejce fragment napisu: RTZ.

Oprawa $w$ tekturę obciągniętą $w$ całą sk. cielęcą, barwioną na brạzowo, z rameczką wycıśnıętą lıniamı prostymi na ciemno. Szycie na 2 rzemykı. Brzegı kolorowane na czerwono.

Proweniencja: 1. "Ad usum Fri Terentiano Capucino. mp", Napis na k. 1.

2. Biblioteka OO. Kapucynów Kraków. Sygn.: 9 A-20; Nr LIV (o. Z. G.).

40. Łac. 1786-1787. $21.5 \times 16.5 \mathrm{~cm}$. K. 96. Opr. płsk. wsp.

"Theologia moralis omnes succincte complectens materias practicas pro utilitate confessariorum ac examinandorum in duas partes divisa moralem et sacramentalem. Auctore P. Fr. Josepho Antonio Caesaremontano ${ }^{34 a}$, Ordinis Minorum S. Francisci Capucinorum bina vice ministro provinciali et $s$. theologiae lectore. Pars prima materias morales ad virtutes ac vitia spectantes, complectens, iuxta normam iuris romani et gallici. Conscripta per Fratrem Brunonem in Conventu Vinniciensi die 17 ian. $1786^{\prime \prime}$.

Inc.: k. 2: „Hic tractatus in quinque principales dividitur $\mathrm{X}$ a Deo per originale contractum stare nequit", k. 91v.

Szkoła: Studium domestıcum kapucynów w Winnicy. Lektor: o. Poncjan Szarkowsk1 ${ }^{35}$. Skryptor: o. Brunon Albricht ${ }^{36}$.

Karty niezapisane: $1 \mathrm{v}, 24 \mathrm{v}, 25 \mathrm{v}, 42 \mathrm{v}, 43 \mathrm{v}, 54 \mathrm{v}, 71 \mathrm{v}, 84 \mathrm{v}, 96 \mathrm{v}$. Bardzo liczne glosy marginalne. Blok rękopisu składa sıę $\mathrm{z}$ dwóch gatunków papreru siwego i bıałego, arkusze przekładane. Niektóre składkı mnıejsze od wymiarów podanych w ogólnym opisie. Inskrypcja: k. 96: "Finivi 9 februarii $1787^{\circ}$.

Składkı: 8. Ternion 5. Seksterniony $1,2,4$ bez 1 k., 6, 7, $8+1$ k. Składka $3 \mathrm{ma} 18 \mathrm{k}$.

Filigrany: zdobnik z krzyżem na frontowej wyklejce. Data 1784, k. 71. Tarcza herbowa $z$ koroną 1 jeleniem $w$ herbie, $k$. 25. Taka sama $z$ jeleniem w biegu, k. 91. Motyw liśc1, k 84. Liczba 86, k. 59.

Oprawa w tekturę szara szmacianą. Grzbiet i rogi obciągnięte sk. cielęcą barwioną na brązowo. Okładki obciagnnięte papierem czerpanym

s4a Józef Antonı Hirsınger z Kayersberg, ur. 1705, do zak. wstąpil 1726, zm. 1777. Lektor teologii, trzykrotny prowincjal prowncji alzackiej, pisarz. - Lexicon capuccinum szp. B65; Catalogus scriptorum s. 26.

${ }_{35}$ Ur. 1749, do zak. wstapil 1767, zm. 13 I 1814 w Winnıcy. Prowincjał prowincji ruskiej, aktualny gwardian klasztoru. - CPP $\mathrm{nr}$ 338; Mortuologium, jw.; O. Z. Gor $11 \mathrm{ck}$, jw. s. 320-321; Por. Diarıusz oO. Kapucynów winnickıch od początku załozenia klasztoru. Rkps Bibl. UJ nr 5910 s. 142 ,

so Ur. 5 XI 1762, do zak. wstapił 1782, zm. 26 I 1306 W Krakowe. - CPP nr 405; Mortuologium pod dniem $25 \mathrm{I}$. 
kolorowanym na brązowo. Szycie na 3 rzemienie. Brzegı nakrapıane kolorem niebleskim.

Proweniencja: 1. Fr. Brunon.

2. Klasztor OO. Kapucynów. Kraków. Pieczęć owalna na k. 1 i wyklejce frontowej. Sygn.: $14 \mathrm{H}-14$; LXXIX (O. Z. G.).

Uwagi: rkps zawiera streszczenie dzieła: P. Josephus Antonius $\mathrm{C}$ a es a $\mathbf{r}$ e m ontanus: Theologia moralis... Vol. 2, Argentinae 1767. Ed. 2, Venetiis 1772. Por. Lexicon Capuccinum, Romae 1951 s. 865; Catalogus scriptorum Ordinis Minorum S. Francisci Capuccinorum ab anno 1747 usque ad annum 1852 sive appendix ad Bibliothecam Scriptorum Capuccinorum a P. Bernardo Bononiensi elusdem Ordinis editam anno 1747. Romae 1352 s. 26.

41. Eac. $1786-1787.21 .5 \times 16.5 \mathrm{~cm} . K .157$. Opr. sk. wsp.

„Theologia moralis omnes succincte complectens materias practicas pro utilitate confessariorum et examinandorum, in duas partes moralem et sacramentalem divisas. Auctore R. F. Josepho Antonio Caesaremontano Ordinis Minorum Sancti Francisci Capucinorum, bina vice ministro provinciali ac ss. theologiae lectore. Conscripta a F. Mathia theologo".

Inc.: k. 1: „Hic in quinque principales dividitur quaestiones $\mathrm{X}$ in his matteriis experientiam habentem, adhibeat", k. 157v.

Streszczzenie popularnego podręcznika teologii moralnej, używanego powszechnie przez kapucynów.

Szkoła: Studium domesticum kapucynów w Winnicy. Lektor: o. Poncjan Szarkowskı. Skryptor: o. Maciej Smetana ${ }^{37}$, Morawıanin.

Oryginalna paginacja: 183 , nlb. 1; 127. Karty niezapisane: 20v, 42v, $76 \mathrm{v}, 135 \mathrm{r}$. Wstawka na k. 43 I 44 obejmuje rysunki: ,cognatio legalis". „cognatio spiritualıs", "cognatio naturalis". Papier czerpany siwy. Blok rękopisu niejednolity, niektóre składki o mniejszych wymıarach niż w ogólnym opisie.

Składki: 14. Kwaterniony 1, 9, 12. Kwinterniony 6, 7, 8, 10, 13. Seksterniony 2 , 3 bez $1 \mathrm{k}$., 4 bez $1 \mathrm{k}$., 5 . Septentrion 11 . Okternion 14 bez $4 \mathrm{k}$. wyclętych.

Filigrany: liczba 86 na wyklejce frontowej. Liczba 5 na k. 43, 76. Litera I, k. $42 ;$ O, k. 9.

Oprawa broszurowa. Blok książkı obciagnnięty tylko w twardą sk. brązową. Bokı cięte równo z blokıem rękopısu. Sk. podklejana papıerem czerpanym. Szycie na 3 taśmy.

Proweniencja: 1. Fr. Maciej kapucyn.

Bibioteka OO. Kapucynów. Kraków. Pieczątka olkrągła i owalna na wyklejce frontowej i k. 159v. Sygn.: $14 \mathrm{H}-7$; Nr LVII (o. Z. G.).

42. Łac. 1787. $20 \times 16.5 \mathrm{~cm}$. K. 99. Opr. plsk. wsp.

"Theologia morallis omnes succincte complectens materias practicas pro utilitate confessariorum et examinandorum in duas parles moralem scilicet et sacramentalem divisas. Aucthore Patre Fratre Joanne Antonio Caesaremontano Ordinis Minorum S. P. N. Francisci Capuc. bina vice

${ }^{37}$ Ur. 25 I 1761, do zak. Wstąpił 1782, zm, w prowincji ruskıej. - CPP nr 408. 
ministro provinciali et $s$ sanctiae theologiae lectore. Pars I materias morales ad virtutes et vitia spectantes complectens iuxta normam iuris romani et gallici. Conscripta summa cum navitate et diligentia nec non detractione somni nocturni a V. P. F. Conrado ${ }^{38}$ theologiae studlioso. Quam A. V. P. Pontianus vir non minus doctus, quam sapiens publice explanavit in Conventu nostro Vinnicensi a. D. 1787".

Inc.: $\mathrm{k} .1$ : „Resp. actus hominis est qui $\mathrm{X}$ a Deo per originale contractum stare nequit", k. 90v.

Oryginalna paginacja: nlb. 2, 180, nlb. 16. Karty niezapisane: 99. Spis treści: k. 91-99. Inskrypcja: k. 98v: „finivı scriptionem 17 martii 1787 in Conventu Vinnicensi ad B. V. Mariam Angelorum". Rękopis składa sıę z arkuszy papieru czerpanego, siwego 1 białego.

Składki: 9. Ternion 9. Kwinterniony 1, 3. Seksterniony 2, 4, 5, 6, i, 8 bez $1 \mathrm{k}$.

Filigranów nie ma.

Oprawa $\mathrm{w}$ tekturę szarą. Grzbiet i rogi obciągnięte sk. barwioną na brązowo a okładkı papierem klajstrowym niebıeskim w deseń, rysowanym ręcznı. Szycıe na 3 wręzy. Brzegı nakrapiane na niebıesko.

Proweniencja: 1. Fr. Konrad, kapucyn.

2. Biblioteka OO. Kapucynów w Olesku. Pieczątka okrągła na wyklejce frontowej i k. 94 .

3. Biblioteka OO. Kapucynów. Kraków. Pieczątka okrągła na odwrocie frontowej okładki i k. 98v.

Uwagi: por. $\mathrm{nr} 40$.

43. Eac. 1799. $19.5 \times 17 \mathrm{~cm}$. K. 140. Opr. ptsk. wsp.

"Theologia universa in moralem polemicam et speculativam divisa. Compendium ex selectis quibusdam magis usitatis auctoribus succincte collectum. Per R. P. Thadaeum Ordinis Minorum S. P. Francisci Capucinorum p.t. ss. theologiae lectorem, definitoremque Prov[inciae] Pol[onae] anno a Partu Virginis 1799".

Inc.: k. $3:, \S 1$. Moralis generatim sumpta: scientia est X nec contra periculum cesset industria“, k. $138 \mathrm{v}$.

Treśé: teologia moralna od k. 2-100v. Teologia polemiczna od k. 101-138v.

Szkoła: Studium domestıcum kapucynów w Krakowie. Lektor: o. Tadeusz Krawczyński ${ }^{39}$.

Reklamanty. Karty niezapisane: 1v, 139, 140. Oryginalna paginacja: nlb. 2, 275, nlb. 4. Tytuł w podwójnej, pogrubionej ramce, złączonej w przekątniach dubeltowa linią.

Składk1: 35 binionów.

3s Ur. 4 I 1769, do zak. wstąpił 1782, zm. 7 VII 1790 w Warszawie. - CPI nr 403; Mortuologium podaje datę śmierci 27 VII.

39. Ur. 13 XI 1749 w Warszawie, do zak. wstąpił 1766, zm. 7 V1 1811 w Krakowie. Dwukrotny prowncjał, pisarz. - CPP nr 325; Mortuologium, JW.; Estr. XII 501; J o c h e r nr 9272; Kitka prac wydanych anonjmowo, wiele pozostało w rękopisach, por. O. Z. Go r $11 \mathrm{ck} 1,3 W$. s. 313-319; Catalogus scriptorum s. 37; H. Ko z e r s k a : Straty w zbiorze rękopisów nr 98-101. Rękopısy te splonęly w Bibliotece Narodowej w Warszawie w czasie powstanıa warszawskiego 1944. 
Filigrany: zdobnik z krzyżem na frontowej wyklejce. Zdobnik a pod nim inicjały J F L, k. 139.

Oprawa $\mathrm{w}$ tekturę szarą. Grzbiet i rogi obciągnięte sk. cielęcą barwioną na brązowo. Okładki obciągnięte papierem klajstrowym czerpanym, barwionym na czerwono $z$ narzutem koloru zielonego. Szycie na 4 sznurki. Brzegi nakrapiane $w$ pasy czerwone.

Proweniencja: 1. O. Tadeusz Krawazyński.

2. O. Filip Szumowski.

3. Biblioteka OO. Kapucynów. Kraków. Pieczątka okrągła na k. 1v, 138v. Sygn.: 9 D-5; Nr XLVII (a. Z. G.).

44. Eac. 1799. $23 \times 19 \mathrm{~cm}$. K. 123. Opr. brosz. wsp.

„Theologiae universae in moralem polemlicam et speculativam divisae compendium. Ex selectis quibusdam magis usitatis auctoribus succincte collectum per R. P. Thadaeum pro tunc actualem definitorem nec non bina vice lectorem. Anno a Partu Virginis 1799".

Inc.: k. 3: „§ 1mus. Moralis generatim sumpta: scientia est X fieri potest etiam extra confessionem", k. 122.

Szkoła: Studium domesticum kapucynów w Krakowie. Lektor: o. Tadeusz Krawczyński. Skryptor: o. Rafał Tronowski ${ }^{40}$

Reklamanty rzadkie. Karty niezapisane 1v, 77, 122v, 123. Karta doklejona: 96. Tytuł kodeksu w podwójnej ramce, zaciemnionej w rogach.

Składki: 19. Binion 19. Terniony $1-13$ lecz 13 bez $1 \mathrm{k}$. Kwaterniony $14-18$

Filigrany: orzeł $\mathrm{w}$ koronie $\mathrm{z}$ tarczą herbową, $\mathrm{z}$ mieczem i jabłkiem w szponach, k. 77, 123. Równoramienny krzyż, ponad nım inicjały A I M, ponıżej nazwa: Grosmorau, k. 1, 19. W pıęknej, ozdobnej winietce stylizowany plaster miodu $\mathrm{z}$ napisem: Honig, poniżej inicjały $\mathrm{J} \mathrm{H}$ and $\mathrm{Z}, \mathrm{k} .96$.

Oprawa brulionowa $w$ papier czerpany sıwy, zniszczony na grzbiecie. Okładki oderwane. Szycie na 2 sznurki.

Proweniencja: 1. „Pr. Fr. Raphael Capuemus“. Napis na k. tytułowej.

2. Biblioteika OO. Kapucynów. Kraków. Sygn.: $\operatorname{Nr} \operatorname{LXXXV}$ (o. Z. G.).

45. Eac. II pot. XVIII w. $19.5 \times 12 \mathrm{~cm}$. K. 91. Opr. sk. wsp.

Theologia moralis.

Inc.: k. 1: „De voluntario et voluntarium quid sit et quotuplex $\mathrm{X}$ habentis iurisdictionem nec non confessarius", k. $89 \mathrm{v}$.

Kompendium teologii moralnej. Karty niezapisane: $7,8,20 \mathrm{v}, 27 \mathrm{v}, 28,31$, $34 \mathrm{v}, 35 \mathrm{r}, 38,39 \mathrm{r}, 45,46,54 \mathrm{v}, 55,65 \mathrm{v}, 66,71,90,91$. Na marginesach numery paragrafów.

Składki: 12. Binion 12. Pozostałe kwaterniony lecz 3 bez $1 \mathrm{k}$.

Filigrany: tarcza herbowa $z$ koroną pięciopałkową, k. 91. Nazwisko: J. Honig, k. 54 .

Oprawa w tekturę szarą, obciągniętą sk. cielęcą, barwioną na brązowo.

10 Ur. 24 II 1774, do zak. Wstąpil 1795, zm. 11 VIII $1835 \mathrm{w}$ Krakowie. - CPP nr 457: Mortuologium, Jw 
$\mathrm{Na}$ okładkach odcıśnıęta ramka z linii prostych na ciemno. Szycie na 4 więzy. Kapitałka szyta. Brzegi nakrapiane na niebiesko.

Proweniencja: Biblioteka OO. Kapucynów. Kraków. Sygn.: 22 D-50; Nr XXXIV (o. Z. G.).

46. Eac. $1826.18 .5 \times 12.5 \mathrm{~cm}$. K. 94. Opr. brosz. wsp.

„Compendium theologiae moralis. Selectisstimum ac breviter confectum R. P. authore Joseph Caesaremontano. Anno Domini 1826. I.e martii 3a. Fr. Josephi a Copertino ${ }^{41}$ Capucini".

Inc.: k. 3: „Definitur, quod stit scientila practica $\mathrm{X}$ haeretici cuiuscumque eorumque receptatores fautores", k. 94.

Składki: 6 okternionów.

Filigrany: lilia, k. 3, 4. Fragment nazwy zakończony literami Dorf, k. 5. Krzyż, k. 15.

Oprawa broszurowa. Szycie na 2 sznurki.

Proweniencja: 1. O. Józef Krzysikiewicz, kapucyn.

2. Biblioteka OO. Kapucynów w Olesku. Pieczątka okragła na k. 1, 31, 63. Sygn.: XII 34.

3. Biblioteka OO. Kapucynów. Krakków.

Uwagi: por. $\mathrm{nr} 40$.

47. Łac. 1829. $20 \times 13.5 \mathrm{~cm}$. K. 104. Opr. ptsk. wsp.

"Compendium ex theologia morali R. P. Antonii Caesarem[ontani] Ordinis S. P. Francisci Capucinorum. Anno Dni 1829".

Inc.: k. 2: „Quid sit theologia moralis? R. Est scientia $\mathrm{X}$ eos iungendi coram fidissimis testibus", k. 103.

Reklamanty. Blok rękopisu składa się z papieru siwego. Kursywa czytelna, równa i bez skrótów.

Składki: 26 biniony.

Filıgrany: w tarczy o kształcıe serca pętla, k. 103. Nazwa: Końskie, k. 104.

Oprawa w tekture. Grzbiet i rożki obciagnięte sk. brązową. Ubytek skóry w górnej częścı. Papier czerpany, barwiony techniką klajstrową z naklejonym szyldem na frontowej okładce. Szycie na 2 sznurki. Brzegi czerwone.

Proweniencja: Biblioteka OO. Kapucynów. Kraków. Sygn.: 14 E-22; $\mathrm{Nr}$ XXXV (o. Z. G.).

Uwagi: jak pod nr 40.

48. Pol. $1832.17 .5 \times 10.5 \mathrm{~cm}$. K. 60. Opr. brosz. wsp.

„Traktat o sakramencie ś. pokuty".

Inc: $\mathrm{k}$. 1v: ,Że sakrament pokuty jest najpożądańszą dla dobra $\mathrm{X}$ jedna wprawdzie zapowiedź jest dostateczna", okładka tylna wewnętrzna. Od k. 58-60v: „O sakramencie małżeństwa“.

Szkoła: Studium generalne dla zakonników we Lwowıe. Skryptor: o. Franciszek Borgiasz Schemik ${ }^{42}$, kapucyn.

i1 Ur. 31 VIII 1800, do zak. Wstąpil 1822, zm. 21 V 1882 w Krośnıe. Nazwisko Krzysik zmienił na Krzysikıewicz. Prowincjal prowincji galicyjskiej przez 5 trzechleci. - Mortuologium. Jw.; O. A. W o j $n$ a r, Jw. s. $39,78$.

42 Ur. 24 IV 1798 (1799 ?), do zak. wstapil 1826, zm. 26 IV 1849 w Olesku. - Mortuologium, jw. 
Inskrypcja: k. 1: „Fr. Franciscus Borgias Schemik Kap. Leopoli die 19 decembrıs 1832. Apud P. P. Dominicanos", Blok rękopisu z grubego sıwego papieru czerpanego.

Składki: 8. Ternion $1+1 \mathrm{k}$. Pozostałe kwaterniony lecz 8 bez $3 \mathrm{k}$. Filıgranów nie ma.

Oprawa $w$ broszure, obcıągnięta sınym papıerem czerpanym, podklejonym takimż białym. Szycie na 3 sznurkı.

Proweniencja: 1. „Fr. Franciscus Borgias Schemik“ nap1s na k. 1.

2. Biblioteka OO. Kapucynów w Olesku. Sygn.: IX 3z̈.

3. Biblioteka OO. Kapucynów. Kraków.

49. Eac. 1840. $21 \times 16.5 \mathrm{~cm}$. K, 102. Opr. ptsk. wsp.

"Compendium theologiae moralis. 1840 ".

Inc.: k. 2: „Q. Quis dicendus est christianus atque catholicus X ecclesiis et monasteriis sine licentia papae", k. 102.

Glosy marginalne 1 interlınearne. Blok rękopisu składa się $z$ dwóch gatunków papieru: siwego 1 białego. Wykaz studentów teologii na.k. tytulowej: „A. V. P. Leander. V. Pr Felix. V. Pr Leo a Cracovia. A. D. 1857“.

Składk1: 12. Biniony 2, 12. Ternion 1. Kwaterniony 3, 4, 6, 7. Pozostałe seksterniony.

Filıgranów nue ma.

Oprawa w tekturę. Grzbiet 1 rogi obciągnięte sk. brązową. Papier okładek klajstrowy, marmurkowy. Szycie na 3 sznurkı.

Froweniencja: Biblioteka OO. Kapucynów. Kraisów. Pieczałtka okrągla na k. 1v, 102v. Sygn.: $14 \mathrm{E}-3$; Nr LXIII (o. Z. G.)

50. Eac., pol. I pot. XIX w. $17.5 \times 10.5 \mathrm{~cm} . \mathrm{K} .72$. Opr. brosz. wsp. "Compendium theologiae morralis".

Inc.: k. 1: „3tio. Ut actus humani dicitur $\mathrm{X}$ et loci securitate aliud particulare", k. $69 \mathrm{v}$.

Od k. $70-72 \mathrm{v}$ dyspozycje kazań w jęz. polskım.

Składki: $3.1 \mathrm{ma} 20 \mathrm{k} ., 2-36 \mathrm{k}$. i 3-18 k.

Filigrany: w otoku promieni Matka Boska z Dzleclątkiem, w koronach, k. 2. Fragment dużego polskiego orła z jabłkıem i berłem w szponach, k. 9, 72 .

Oprawa broszurowa. Ksıążeczka obciągnięta w całości sınym papierem czerpanym, z takąż wyklejką. Szycie na 3 sznurki.

Proweniencja: Biblioteka OO. Kapucynów. IKraków. Sygn.: Nr I (o. Z. G.).

51. Łac. I pol. XIX w. $23 \times 18 \mathrm{~cm}$. K. 77. Opr. brosz. wsp.

"Compendilum theologiae moralis".

Inc.: k. 1: „Q. Quid est theologia moralis? R. Theologia morladis definitur $\mathrm{X}$ cuiuscumque sectae eorumque receptatores fautores", k. 74 .

Reklamanty. Karty niezapisane: 74v, 75-77. Blok rękopisu składa się $\mathrm{z}$ prążkowanego siwego papıeru czerpanego.

Składki: 10 kwaternionów lecz 10 bez $2 \mathrm{k}$. wyciętych.

Filigrany: tarcza herbowa $\mathrm{z}$ trąbką, wyklejka frontowa, k. 3, 4. Stylizowane inicjały: $J$ M, k. 2. 
Oprawa w tekturkę sklejaną z makulatury, obciągnięta w całości brązowym papierem klajstrowym. Szycie na 2 rzemyki pergaminowe. (o. Z. G.).

Proweniencja: Biblioteka OO. Kapucynów. Kraków. Sygn.: 14 G-23; Nr LXII

52. Łac. I pot. XIX w. $20 \times 17.5 \mathrm{~cm}$. K. 96. Opr. brosz. wsp.

"Compendium theologiae moralis".

Inc.: k. 1: „Quaestio. Quid est theologia moralis? Respondeo X ac v1 utroque foro obligat ad poenam", k. 96.

Kodeks napisał zapewne jeden z kleryków kapucyńskich. Reklamanty. Karty nıezapisane: 54r, 96v. Glosy marginalne. Blok rękopisu składa się z papieru siwego.

Składki: 13. Binion 3. Ternion 11. Seksternion 2. k. Pozostałe kwaterniony, lecz 13 bez $6 \mathrm{k}$. wyciętych.

Filigrany: inicjały I F I nazwa Lochow, k. 5. Matka Boska w koronie z Dziecıątkiem, wsparta o półksiężyc, k. 15, 18. Kotwica zakończona w górze gwiazdką pięcioramienną, w środku inicjały I D, k. 38, 39.

Oprawa. Brulion, broszura. Oprawa w papier czerpany, barwiony klajstrowo. Szycie na 2 tasıemki.

Proweniencja: Biblioteka OO. Kapucynów. Kraków. Sygn.: 14 F-29; $\mathrm{Nr}$ LXXIII (o. Z. G.).

53. Łac., pol. I pot. XIX w. $21.5 \times 18.5 \mathrm{~cm}$. K. 62. Opr. brosz. wsp. „Compendium theologiae moralis".

Poditytu1: "Cały rozidzial de conscientia, de peccatis, de sacramentis".

Inc.: k. 1: „Q. Quid est theologila moralis? R. Theologia moralis definitur $\mathrm{X}$ salvo charactere, qui est indelebilis", k. $62 \mathrm{v}$.

Rękopis pochodzi z jednego ze studium domestıcum kapucynów polskich. Reklamanty. Glosy interlinearne bardzo liczne w postaci tłumaczeń polskich lub wstawek łacıńskich.

Składkı: 6. Kwaterniony 4 bez 1 k., 5. Seksterniony 1, 2, 3, 6 bez $1 \mathrm{k}$.

Filigrany: orzeł $\mathrm{z}$ berłem $\mathrm{w}$ jednym szponıe 1 jabłkiem $\mathrm{w}$ drugım, tak berło jak 1 jabłko zakończone krzyżykıem, u dołu mncjały $\mathrm{H} \mathrm{W,} \mathrm{k.} \mathrm{43,} 54$. Nazwisko: Franckie(?), k. 20.

Oprawa broszurowa.

Proweniencja: Biblioteka OO. Kapucynów. Kraków. Pieczątka owalna na oibydwóch okktadkach frontowych. Sygn.: $14 \mathrm{H}-18$.

54. Łac. I pot. XIX w. $19.5 \times 12 \mathrm{~cm}$. K. 84. Opr. brosz. wsp.

"Theologia moralis omnes succincte complectens materias practicas pro utilitate confessariorum ac examinandorum in duas partes, moralem et sacramentalem divisas".

Inc.: k. 2: "Theologia monalis definitur quod sit scientia $X$ petat licentiam eos iungendi coram fidissimis testibus", k. 84 .

Oryginalna paginacja: nlb. 2, 175, nlb. 1. Karty niezapisane: 1v, $84 \mathrm{v}$. Blok rękopisu składa się $\mathrm{z}$ papieru czerpanego siwego (do k. 54 włącznie) 1 z papieru czerpanego bialego.

Składki: 12. 8 ma 2 k. Binion 2. Ternion 12. Pozostałe kwaterniony. 
Filigrany: fragment filigranu w lewym górnym rogu karty.

Oprawa broszurowa, obciągnięta papıerem czerpanym sıwym. Szycie na 3 sznurki.

Proweniencja: Biblioteka OO. Kapucynów. Kraków. Sygn.: 14 F-28; Nr XXXVIII (o. Z. G.).

55. Łac. I poł. XIX w. $17.5 \times 10.5 \mathrm{~cm}$. K. 148. Opr. ptsk. wsp.

Casus conscientiae.

Inc.: k. 3: "Aquis immersus inventus est senex, quem $\mathrm{X}$ domi reservasset, et pauperi subvenire debuit", k. 146v.

Kazusy moralne ponumerowane od 1-208. Karty niezapisane: 1, 2, 147, 148. Blok rękopisu składa sıę z papieru czerpanego siwego.

Składki: 18 kwaternıonów.

Filigranów nie ma.

Oprawa w tekturę. Grzbiet i rogi obcıągnięte skórą. Papıer marmurkowy litografowany. Szycie na 2 sznurki.

Prowenjencja: Biblioteka OO. Kapucynów. Kraków. Pieczątka olkrągka na odwracie okładki frontowej. Sygn.: $9 \mathrm{D}-1$; $\mathrm{Nr}$ LXXI (o. Z. G.).

56. Eac. I pot. XIX w. $19 \times 11.5 \mathrm{~cm}$. K. 168. Opr. ptsk. wsp.

.,Theologia monalis omnes succincte complectens materias practicas pro utilitate confessariorum ac examinandorum. Authore P. F. Josepho Antonio Caesaremontano Ordinis Minorum S. Francisci Capucinorum bina vice ministro provinciali et ss. theologiae lectore. Pars secunda. Venetiis MDCCLXXII. Apud Franciscum ex Nicolao Pezzara. Superiorum permissu ac privilegio".

Inc.: k. 2: „Sacramentum in genere definitur, signum sensibile rei sacrae $\mathrm{X}$ in his materiis experientiam habentem, adhibeat", k. 168 .

Dokładna kopia druku jw. Karty niezapisane: 1v, 168v. Karta tytułowa rubrykowana, podobnie jak nagłówki rozdziałów a nawet ważniejsze zdania w tekście.

Składki: 21 kwaternionów.

Filıgrany: inıcjały $\mathrm{D} \& \mathrm{G}, \mathrm{k}, 1,13$. Fragment tarczy herbowej z koroną pıęcıopalkową, k. 5. Nazwısko: B. Blauw, k. 8, 15.

Oprawa w tekture sklejaną z makulatury druku polsklego. Grzbiet 1 rogl obciągnıęte sk. cielęca, barwioną na brązowo. Okładkı obcıə̨gnięte papierem czerpanym marnurkowym na karagenie. $\mathrm{Na}$ grzbiecıe wokól więzów 1 przy kapitałkach tłoczony na ciemno drobny ornament. Zamiast kapitałkı rzemyk podciągnięty pod zawiniętą skórę u góry i u dołu grzbietu. Szycie na 4 więzy. Brzegi czerwone.

Proweniencja: 1. „Fr. Michael Cap“. Napis na wyklejce.

2. Eiblioteka OO. Kapucynów. Kraków. Sygn.: XXXI (o.Z.G.).

Uwagi: por. nr 40. 


\section{HOMILETYKA}

57. Pol., Zac. 1681. $20 \times 15 \mathrm{~cm}$. K. 239. Opr. perg. wsp.

Kazania niedzielne ì śwtiąteczne.

Inc.: k. 1: „Dzień on gniewu Bożego, dzień wielki $\mathrm{X}$ co daj to Chryste Jezu. Amen“, k. 232.

„Index concionum in hoc libro contentarum", k. 232-233, podaje 38 kazań niedzielnych i świątecznych. Poza tym kodeks posiada jeszeze „Index rerum praecipuarum in hoc libro contentarum". k. 234-239. Foliacja oryginalna: 239, nlb. 6. Liczne glosy marginalne. Autorem jest nieznany zakonnik. Potwierdza to napis na odwrocie wyklejkı frontowej: „Hic continentur selecta, et multo studio elaborata, in praesentia regum a quodam relıgioso ecclesiaste variis in locis perorata. $\mathrm{Tu}$, qu legis, applica conceptu1 tuo et utere non ad ostentationem et vanam gloriam, sed ad maiorem Dei gloriam et animarum emolumentum". Jakkolwiek kodeks wyszedł spod jednej ręki, to napıs powyższy, spis treści. inwokacja z ostatniej karty oraz podpısy na tejże pochodzą od ks. Jana Białasa, który zakończył rękopis następująco: "Qui legis mihi indigno Joanni Białas Crosn[ensil plebano Jedlicensi precare requiem sempiternam et utere sis ad gloriam Dei"*, k. 323. $\mathrm{Na}$ wyklejkach „złote myśli“, jedna w jęz. polskım, pozostałe w jęz. łac.

Wyklejka frontowa:

"Quod tu scis non est tuum, nisı quod sciat et alter".

Wyklejka tylna:

"Głos nie mój, zaś medyka za medyki stanie,

Myśl. wesoła, dicta w czas, mądrych jest zdanie".

Składkı: 17 o skomplikowanym układzıe kart.

Filigrany: w tarczy herbowej podwójny krzyż, k. 216, 221. Tarcza herbowa $\mathrm{z}$ koroną pięciopałkową, $\mathrm{k}, 237$.

Oprawa w tekturę szarą szmacianą. Obciągnıęta pergaminem barwionym na żółto. Grzbiet wzmocniony paskami pergaminowymi. Przy grzbiecle podwójna linia tłoczona na ciemno. Szycie na 2 rzemienie.

Proweniencja: 1. Ks. Jan Białas, proboszcz w Jedliczach.

2. „Adm. atque Rndo Dno Remigio Eopacki ordinario concionatori Pinczlev Adm. Rndo Martino Stanisl. Kochanowski parocho Zagas[censi] dono oblatus est iste liker a. D. 168111 novembris. Cum puncto certo in festo Sti Martini perorato in eadem festo in templo Zagoscensi". Napis na odwrocie okładki frontowej.

3. "Librum hunc Stan. Kruszynski Camerarius Sandecensis CC. LL. offert". Napis na wyklejce frontowej.

1. Bibliateka OO. Kapucynów. Kraków. Pieczątka okrągła na odwrocie wyklejki frontowej i k. 233v.

58. Pol., zac. $1735.20 .5 \times 16 \mathrm{~cm}$. K. 133. Opr. płsk. wsp.

Kazania niedzielne i świąteczne.

Inc.: k. 1: „Poki żyjemy na śwriecie $z$ daleka stojemy od Chrystusa $X$ i zemidlała, albo zdesperowane przywróci siły“, k, 133.

Kodeks składa się $z$ dwóch części. Pierwsza czesść (k. 1-64v) obejmuje kazania niedzielne 1 śwıąteczne. Druga część (k. 65-133) zawiera tzw. "Notata" to jest materiały do kazań z Pisma św., historii, różnych autorów j przykłady z życia. 
Rękopis nie posiada karty tytulowej i 4 początkowych. Reklamanty. Paginacja oryginalna zachowana od $5-80$, dalszych brak. Po $64 \mathrm{k}$. brak 12 kart, które zostały wycięte. Karty niezapisane: $19 \mathrm{v}, 27 \mathrm{v}, 38 \mathrm{v}, 42,48 \mathrm{v}$, $54,133 \mathrm{v}$. Glosy marginalne.

Składki: 29. 1, 3, 6, 9, 11, 13, 15, 18 mają po $2 \mathrm{k}$. Binıny 2, 4, 5, 7; $8,14,16,17,19,20$. Terniony 12, 21. Pozostałe kwaterniony lecz $29+1 \mathrm{k}$.

Filigrany: Matka Boska stojąca na półksıężycu, obok dwie lilıe, u dołu napıs: S. Maria, k. 54. Inicjały: M B, k. 53. Mężczyzna z kielichem, kobieta z bukietem kwiatów, k. 90.

Oprawa w tekturę szarą. Grzbiet i rogi obciągnięte sk. cıelęcą barwıoną na brązowo. Okładki obcıągnięte papierem klajstrowym barwionym kolorowo. Wzdłuż grzbietu linia tłoczona na ślepo. Na grzbiecie siedem potrójnych linii łłoczonych $\mathrm{w}$ ten sam sposób. Szycie na 2 rzemienie.

Proweniencja: Biblioteka OO. Kapucynów. Kraków. Sygn.: Nr XLI (o.Z.G.).

59. Pol., łac. I poł. XVIII w. $22 \times 17 \mathrm{~cm}$. K. 58. Opr. płsk. wsp.

Kazania niedzielne i świąteczne.

Inc.: k. 2: „I w niebosz wtenczas kierow'ać oczy? gdy gasnąc X i w niebie co daj miłosierny Jezu", k. 58v.

Kazania stanowią pracę ks. Wojciecha Kaminjskiego ${ }^{43}$. Każda strona kodeksu znaczona w górnym margınesıe inicjałami JMJ lub krzyżykiem. Reklamanty. Paginacja oryginalna: 114, dalej $3^{1 / 2}$ składkı wyrwane. Frontowa wyklejka zapisana tekstem "Renovatio professionis" I wıerszem w jęz. łac.

Składki: 8. Ternion 1. Pozostałe kwaterniony ale 8 posiada tylko $3 \mathrm{k}$., reszta wyrwana.

Filigrany: tarcza herbowa, k. 3,4 .

Oprawa w tekturę półmiękką. Grzbiet i rogi sk. brązowa. Okładkı obciągnięte papierem czerpanym z marmurkiem grzebienıowym na karagenie. Szycie na 2 sznurki.

Proweniencja: 1. „Opera R. D. Adalberti Kamiński“. Napis na odwrocie okładki frontowej.

2. Biblioteka OO. Kapucynów. Kraków. Sygn.: $570-\mathrm{C}$.

60. Eac. I pot. XVIII w. $20 \times 16 \mathrm{~cm} . K$. 467. Opr. ptsk. wsp. Auxilia cathechetica.

Inc.: $k .1$ : „1. Est summa rerum omnium vitae superioris oblivio $\mathrm{X}$ colore caeruleo pennam in capite gestans", k. 466 .

Treść: rodzaj słownika kaznodziejskiego w alfabetycznym układzie, zawierającego materiały do określonego hasła $w$ postaci definıji, przykładów z Pisma św., Ojców Kościoła i różnych autorów.

Reklamanty. Liczne glosy marginalne. Karty niezapisane; 10v, 12v, 20, $24,29 \mathrm{v}, 41 \mathrm{v}, 42,43,51,58 \mathrm{v}, 59,60 \mathrm{v}, 61,65,75,87 \mathrm{v}, 89,90 \mathrm{v}, 91 ; 94 \mathrm{v} ; 95$; $97,98 \mathrm{v}, 99,115 \mathrm{v}, 117,118 \mathrm{v}, 123 \mathrm{v}, 124 \mathrm{v}, 129 \mathrm{v}, 130,135 \mathrm{v}, 136,146 \mathrm{v}, 147 \mathrm{v}$, $151,154 \mathrm{v}, 155,157 \mathrm{v}, 163,165,166 \mathrm{v}, 167,168 \mathrm{v}, 169,171 \mathrm{v}, 181 \mathrm{v}, 182,183$, $195,203,209,215,218,219,220,222,230 \mathrm{v}, 237 \mathrm{v}, 255 \mathrm{v}, 261 \mathrm{v}, 262,263,269 \mathrm{v}$, $273,274,275,279 \mathrm{v}, 291 \mathrm{v}, 295,302 \mathrm{v}, 306,311 \mathrm{v}, 315 \mathrm{v}, 317 \mathrm{v}, 325 \mathrm{v}, 326,330$, $334,349 \mathrm{v}, 350,352 \mathrm{v}, 358 \mathrm{v}, 360 \mathrm{v}, 366,368 \mathrm{v}, 373 \mathrm{v}, 376,382,386,394 \mathrm{v}, 396 \mathrm{v}$,

43 Moze kazanıa nalezą do jezuity tego samego nazwiska. Por. Enc. Chełm. XIX/XX 219. 
$398,402,408,410 \mathrm{v} 416,421,422,425 \mathrm{v}, 426,433 \mathrm{v}, 449,454,455,457 \mathrm{v}, 458$; $466 \mathrm{v}, 467$.

Składki skomplikowane w układzie i trudne do obliczenia.

Filigrany: mężczyzna z laską (Mojżesz?), k. 89, 91, 218, 467. Matka Boska z Dzieciątkiem w otoku promieni, wyklejka frontowa. Tarcza herbowa z lilla i inicjałami A I u dołu, wyklejka tylna.

Oprawa w tekturę szarą szmacianą. Grzbiet i rogi obciągnięte sk. cielęca barwioną na brązowo. Okładkı obciągnięte papierem czerpanym nakrapianym na brązowo. Grzbiet malowany farbą, która silnie popękała. Szycie na 4 więzy Kapitałka wyszywana dwukolorowa.

Froweniencja: 1. Biblioteka OO. Kąoucynów w Olesku. Pieczątka okrągła na k. 1, 146, 232, 376 .

2. Biblioteka OO. Kapucynów. Kraków Pieczątka okrągła na oidwrocie wyklejki frontowej.

61. Pol., tac. 1784-1795. $22 \times 18 \mathrm{~cm}$. K. 140. Opr. brosz. wsp.

„Kazania niedzrielne“.

Inc.: $\mathrm{k}$. 1: ,Tunc videbitur Filium hominis venientem $\mathrm{X}$ przychodzącego w obłoku z moca wielką i majestatem“, k. 136.

Kodeks zawiera kazania niedzielne pióra o. Idziego Skirona ${ }^{44}$, kapucyna, wygłoszone w kościołach Warszawy i Lublina w l. 1784 (tylko jedno) i 17941795. Napis na k. 28v: „Revidit. Fr. Aegidius lect[or] ind[ignus] die 29 ianuarii 1784 Lublini mmpp". Poza tym każde kazanie posiada objaśnienie: w którą nıedzielę, gdzie i w którym roku zostało wygłoszone. Reklamanty. Spis treści: k. 137-138. Karty niezapısane: 4v, 8v, 12v, 49v, 53, 61, 93v, 101v, $105,113 \mathrm{v}, 128 \mathrm{v}, 136 \mathrm{v}, 138 \mathrm{v}, 139,140$. Glosy marginalne.

Składki: 35. 35 ma 2 k. Pozostałe biniony lecz 10 I $32+1$ k., 11 bez $1 \mathrm{k}$., 30 bez $2 \mathrm{k}$.

Filigrany: inicjały $\mathrm{C} \mathrm{H}$, wyklejka tylna. Inicjały $\mathrm{C} \mathrm{G} \mathrm{N,} \mathrm{k.} \mathrm{2,} \mathrm{4.} \mathrm{Biskup}$ z krzyżem (?), k. 14, 15. Napis: Wadano, k. 37. Orzel z jabłkiem i berlem w szponach, k. 90, 93. Ponad winietką lew w koronie $z$ mieczem a za nim. rycerz z kapeluszem na muszkiecie (?), z lewej strony $\mathrm{w}$ górze napis: Pro Patria, poniżej inicjały W V I, k. 8, 97. Matka Boska z Dzieciątkiem w otoku promieni, k. 53. Fragment tarczy herbowej z choragwia, k. 61. Tarcza herbowa $z$ trzema poprzecznymi linıami, z lilia powyżej i inicjałami $W$ G $w$ dole, k. 102, 105. Kwiat w wazonie, poniżej napis: $\mathrm{P} S \mathrm{~S}$ Eku (?), k. 54, 57.

Oprawa broszurowa. Obciągnięta papierem czerpanym klajstrowym marmurkowym sklejanym $z$ makulatury $z$ druku francuskiego. Szycie na 2 sznurkı

Proweniencja: 1. O. Iỏzi Skiron, kapucyn.

2. Biblioteǩa OO. Kapucynów. Kraków. Sygn.: Nr LVI (o.Z.G.).

62. Pol., łac. I poł. XIX w. $21 \times 15 \mathrm{~cm}$. K. 251. Bez opr.

Kazania okolicznościowe.

Inc.: k. 1: „Rozegrzany miłością bliźniego, a w Boskim miłostierdziu $X$ powiada Rupert opat, że tak tuczne barany...", k. $251 \mathrm{v}$.

Kazania różnych kapucynów z prowincji polskiej i galicyjskiej. K. 192-

44 Ur. 8 IIT 1745, do zak. wstapił 1761, zm. $1 \pm$ III 1814 w Eomży. - CPP nr 289; Mortuologium, Jw.; O. Z. Gor $11 \mathrm{ckl}$, Jw. s. 325-327. 
201: Kazusy o. Damazego Stehlika ${ }^{45}$ z teologii moralnej (w jęz. lac.). Karty niezapısane: $18,19,37 \mathrm{v}, 38,39,48 \mathrm{v}, 57 \mathrm{v}, 58,59,67,75 \mathrm{v}, 85,97 \mathrm{v}, 146 \mathrm{v}, 147$, 167, 210, 224v, 245v. Inskrypcje: k. 8: „R. 1817“; k. 48: „Kazanie na dzień Wszystkıch Swiętych w Modlnicy Wielkiej w r. 1822".

Składki: $38.9,20-22,25,29,30,31,34,35,37$, po $2 \mathrm{k}$. Biniony $14,24+1 \mathrm{k}$, 28. Terniony $11+4 \mathrm{k} ., 18,23,27+2 \mathrm{k} ., 32,33+1 \mathrm{k}$. Kwaterniony 1, 4, 5, $7,8,10,13,15,19,36$. Kwinterniony 16, 17, 26 bez $1 \mathrm{k}, 38+2 \mathrm{k}$. Seksterniony $2,3,6,12 \mathrm{bez} 1 \mathrm{k}$.

Filigrany: inıcjały C C N, k. 33,“39. Miejscowość: In Janowitz, k. 51, 56. Nazwisko: N. A. Sieber, k. 50, 57. Nazwa: KL MO, k. 63, 65. Nazwa: Wadang, k. 93, 94. Napis: C R o 8, Konzept, poniżej nazwısko Sieber, k. 89, 90. Lilia, k. 106. Inıcjały I D, k. 107. Nazwisko: C \& I Honı, k. 122, 125. Tarcza herbowa z koroną pięcropałkową, w polu róg myśliwski, poniżej inicjały: $1 \mathrm{P}, \mathrm{k} .120$, 123, 124, 127. Fragment postaci ludzkiej, k. 167. Fragment inicjałów I L, k. 174, 175. W ozdobnym owalu z dwóch skrzyżowanych gałęzı plaster mıodu $z$ napisem: Honig, k. 190.

Proweniencja: Biblioteka OO. Kapucynów w Krakowie.

\section{KATECHETYKA}

63. Łac. $1649.18 .5 \times 15 \mathrm{~cm}$. K. 124. Opr. perg. wsp.

„In cathechismi ex decreto Concilij Tridentini ad parochos editi expilicationem".

Inc.: k. 1: „Cum inter sacrale scripturae doctrinam $\mathrm{X}$ in qua Christus Dominus residet comprehendit", k. 123.

Rękopis zawiera wyjaśnienia do katechizmu wydanego z nakazu soboru Trydenckiego. Reklamanty. Tytuł, niektóre podtytuły oraz inicjały rubrykowane. $\mathrm{Na}$ k. 123 zdobnikı o motywach kwlatowych. Ramka marginesowa wytłaczana, ramka marginesu bocznego podwójna. Na marginesie brzegowym osıem dzıurkowań. Na k. 124 l tylnej wyklejce tekst katechizmowy pisany poźnıejszą ręką, może Jana Francıszka Sucharskıego z r. 1678. Na tylnej wyklejce napıs pierwszą ręką: „Fine carent librı principioque tui“. Na wyklejce frontowej wiersz w jęz. łac. sławiący Chrystusa oraz następujące zlote myśli:

„Raro placent aliis, qui placuere sibı, Videto ne placeas nulli, dum sibi nemo placet.

Cura facit canas, quamvis homo non habet annos".

Składkı: 31. Ternıon 1. Pozostałe binıony ale 31 bez $2 \mathrm{k}$.

Filıgrany: tarcza herbowa z koroną i krzyżykiem, k. 3, 20.

Oprawa w tekturę obciagniętą w całości pergaminem ze średniowiecznego kodeksu teologicznego zawierającego tekst z księgi proroka Habakuka (rozdz. 3) z kolorowymi inicjałami (minıa, błękıt). Na grzbiecie ślady malowania farbą. Grzbiet w górnej częścı oderwany, okładkı nadgryzıone przez korniki. Szycie na 2 sznurk 1.

Proweniencja: 1. „Ex libris Joannlis Stanis. Chrast. Anno Dni 1649“. Napis na k. 1 .

45 Ur. 22 VIII 1761, do zak. Wstąpił 1777, zm. 10 III $1827 \mathrm{w}$ Sędzıszowıe. Prowıncjał prowıncji galicyjskiej przez 4 trzechlecia. - CPP nr 279; Mortuologium, jw.; O. A. Wojnar. jw. s. $38-39$. 
2. „Ex libris Joannis Francisci Sucharski. A. D. 1678". Napis na k. 1.

- 3. Biblioteka OO. Kapucyınów. Kraków. Pieczątka okrągła na k. Iv i $124 \mathrm{v}$. Sygn.: Nr XXXVII (O.Z. G.) na wyklejce frontowej.

64. Pol., łac. 1786. $18.5 \times 11.5$. K. 310. Opr. sk. wsp.

"Katechizm misyjny“.

Inc.: k. 1: „P. Co to jest katechizm? O. Jest nauka wykładająca X przez ten wszystek czas i poizegnanie z nimi“", k. 310 .

Paginacja oryginalna: 576, nlb. 46. Spıs treści: 288-290v. Inskrypcje: frontowa wyklejka: „Hic liber emptus fl. 2 gr. $15^{\star 4}$. Odwrocie frontowej wyklejki: modlitwa do Ducha św. przed kazaniem „Duchu św. daj natchniene..."; modlitwa po kazaniu „Niech wzrasta nauka trwale, cośmy w Twoim ımıenıu wzięli Boże...". K. 310: „Diebus 10bris anno 1786“. K. 291-3/10: „Observationes pro facienda utiliter doctrina Christıana“. K. 310v: tekst pıeśnı katechımowej „Patrz, czyja ręka ten świat porusza...“.

Składki: 38. 2 ma $40 \mathrm{k}$. Terniony 22, 24, 25, 27-37, 38+1 k. Kwaterniony $1,3-20,21$ bez $1 \mathrm{k}$. Kwinterniony $23,26$.

Filigrany: tarcza herbowa $\mathrm{z}$ koroną 1 napisem Zonen, k. 308, 309. Nazwisko: J. Honig, k. 310.

Oprawa w tekturę brązową obciągniętą w całości sk. c1elęcą barwioną na brązowo. $\mathrm{Na}$ grzbiecie drugie pole górne zamalowane czarną farbą, na nım złocony ręcznıe tytuł. Szycıe na 4 więzy. Ślady kapıtałkı górnej na sznurku. Wokół wıęzów i przy kapitałkach bordiurka z lıstkami, w polach między wıęzamı ręcznıe tłoczony stempel kwıatowy, złocony. Brzegı kolorowane na czerwono.

Proweniencja: 1. "Michael Słabikowski. mpp". Napis na wyklejce frontowej.

2. Bibliotekra OO. Kapucynów. IKraków. Piecząlka okrąłła na odwrocie okkładki frontowej i k. $310 \mathrm{v}$.

65. Pol., tac. 1834. $18.5 \times 11.5 \mathrm{~cm}$. K. $72+32$. Opr. ptsk. wsp.

"Nauki katechizmowe krótkie. 1834. Fr. S. Capuc."

1. k. 1-22. „Krótkie zebranie nauk chrześcijańskich dla dziatków, którzy pierwszy raz mają do $\$$. Spowiedzi' i Komuniii przystępować. 1834 . Fr. S. C[apucinus]".

Inc.: k. 2: „Ojcze nasz, któryś jest w niebiesiech $\mathrm{X}$ na ziemi. P. Co to jest czlowiek?", k. 22.

2. k. 1-72. Zarpiski treści religgijnej.

Inc.: k. 1: „S. Paweł 2 Cor. 5. Ten który nie znał grzechu stał się X Joannes et Maria Magdalena C. 4 Rev. c. 8 S. Brigitae verba Christi‘, k. 72 .

Rękopıs składa się z dwóch części. Druga część rozpoczyna sıę od okładki tylnej, tak że obie częścı w końcowych swoich partiach schodzą sıę ze sobą $\mathrm{w}$ środku rękopısu. Karty niezapısane: cz. 1: $1 \mathrm{v}, 22 \mathrm{v}-32$; cz. $2: 9 \mathrm{v}, 17 \mathrm{v}-18 \mathrm{r}$, $21 \mathrm{v}, 23 \mathrm{r}, 25 \mathrm{v}, 26,31 \mathrm{v}, 32-47 \mathrm{v}, 49 \mathrm{v}, 56 \mathrm{v}, 57,61 \mathrm{v}, 63 \mathrm{v}, 72 \mathrm{v}$. Wklejki: k. 55, $56,60,61-63$.

Składkı: 14. $14 \mathrm{ma} 2 \mathrm{k}$. Terniony 1, 3, 5, 7, 9, 11. Kwaterniony 12, 13. Kwinterniony 2, 4, 6, 8, 10 .

Filigrany: nazwisko: J. Honig, k. 9 z cz. 1. 
Oprawa w tekturę szarą. Grzbiet i rogı obciągnięte sk. cielęcą barwioną na brązowo. Okładki obciągnięte papierem czerpanym marmurkowym. Szycre na 2 paski pergaminowe. Brzegi nakrapiane na niebiesko.

Prorweniencja. 1. „Fr. S. C[apucinus]. Napis na k. $1 \mathrm{w}$ cz. 1.

2. Biblioteka OO. Kapucynów. Kraków. Sygn.: $5 \mathrm{C}-11 ; 16 \mathrm{H}-19$; $\mathrm{Nr}$ LXXXII (a. Z. G.).

66. Pol. $I$ pot. $X I X$ w. $19 \times 12 \mathrm{~cm}$. K. 44. Opr. płsk. wsp.

Katechizm.

Inc.: k. 1: „Ojcze nasz któryś jest $w$ niebiesiech $\mathrm{X}$ Kto by nie uwierzył potempionem będzie. Mar. 16 v. $16^{\prime \prime}, \mathrm{k} .39 \mathrm{v}$.

Autorem katechizmu jest o. Filip Szumowski ${ }^{46}$. Reklamanty. Do strony 16 oryginalna paginacja. Karty niezapisane: 40-44. Poprawki $w$ tekście. Blok papieru sklada się $\mathrm{z}$ siwego papieru czerpanego. $\mathrm{Na}$ tylnej wyklejce napis: „Kopią tej książki odpisałem i zgodność poświadczam" (Podpıs niecrytelny).

Składki: 11. 9 i 11 ma po 2 k. Biniony 2-8, 10. Kwaternion 1 .

Filigrany: na wyklejce frontowej: Witz. Nazwisko: G. Sieber, k. 40, 43.

Oprawa $w$ tekturę $\mathrm{z}$ grzbietem i rożkami obciągniętym skórą cielęcą barwioną, a okładki papierem prasowanym niebieskim.

Proweniencja: 1. O. Filip Szumowski, kapucyn. Pismo jego ręki.

2. Biblioteka OO. Kapucynów w Krakowie. Sygn.: 11 D -57.

67. Pol. I pot. XIX w. $20 \times 12 \mathrm{~cm} . K$. 48. Opr. ptpt. wsp.

„Historia śmięta".

Inc.: k. 1: „P. Co to jest historila? O. Jest to wiadomość rzeczy przeszłych X pomarli i wiele innych zbawiennych i pożytecznych", k. 48v.

Autorem podręcznika jest o. Filip Szumowski. Reklamanty. Paginacja oryginalna: 74 , nlb. 21. Karty niezapisane: 38v, 39, 40. Poprawkı w tekście.

Składk1: 9. Biniony 7, 8, 9. Terniony $1-6$.

Filigrany: nazwisko: G Freud, wyklejka frontowa i k. 12.

Oprawa w tekture. Grzbiet obciągnięty w płótno. Okładkı obcıągnięte papierem czerpanym barwionym na brạzowo. Szycie na 2 tasiemki.

Proweniencja: 1. O. Filip Szumowski, kapucyn. Pismo jego ręki.

2. Biblioteka 00 . Kapucynów. Kraków. Pieczątka okrągła na odwrocie wyklejki frontowej i k. 48v. Sygn.: $19 \mathrm{G}-18$; $\mathrm{Nr}$ L (o. Z. G.).

68. Pol. I pot. XIX w. $20 \times 12.5 \mathrm{~cm}$. K. 35. Bez opr.

„Nauki religijne dla prywatnego użytku ułożone".

Inc.: k. 1: „Ojcze nasz któryś jest $\mathrm{w}$ niebie $\mathrm{X}$ powszechnie przez laskę i miłosierdzie Boskie“, k. 32.

Katechızm ułożony 1 napısany rękę o. Filipa Szumowskiego, kapucyna. Karty niezapisane: 32v, 33, 34, 35. Wklejki: 28a, 34a.

40 Ur. 14 X 1775, do zak. wstapil 1795, zm. 10 VII 1851 w Krakowı. Prowincjał prowincji polskiej, prokurator generalny zakonu w 1. 1824-1825. - CPP nr 459; Mortuologium, Jw.; Lexicon capuccinum szp. 1356; Bullarium cap. IX 383, 384 nota 3; Analecta Ordinis Minorume Capucernorum (Roma). T. $12: 1896$ s. 155 n. 54 . 
Skladki: 8. Binıony 1-7. Kwaternion 8.

Filıranów nie ma.

Proweniencja: 1. O. Filip Szumowski, kapucyn.

2. Biblioteka OO. Kapucynów w Krakowie.

\section{LITURGIKA}

69. Eac. 1693. $13 \times 7.5 \mathrm{~cm}, K .93$. Opr. plperg. wsp.

„Cerimoniae ecclesilastilcae. A. D. 1693“.

Inc.: k. 6: „Cerimoniarii officium est ut amnia reate $\mathrm{X}$ Zoes, Corripiuntur. Zetici, Zotici, Zosimi“", k. 79v.

Kodeks wykonany jedną ręką z wyjątkiem k. 80r. Reklamanty. Karty niezapisane: 1, 2, 3v-5, 80v-93. Karta tytułowa rubrykowana $w$ ozdobnej winietce. Poza tym rubrykowane na k. 6 jedno slowo "Cerimoniarıus" 1 zdobnik na k. $79 \mathrm{v}$.

Składkı: 15. Biniony 11-15 lecz 15 bez $2 \mathrm{k}$. Terniony 2--10. Kwinternion 1.

Proweniencja: 1. „Bibliotheca Ressovienisis Scholarum Piarum". Napisy na k. $8,79 \mathrm{v}$.

2. „P. Desiderii [Lewandowski] Capucini“. Napis na k. 3, 6.

3. Biblioteka OO. Kapucynów w Krakowie.

70. Eac. II pot. XVIII w. $16 \times 10.5 \mathrm{~cm} . K$. 147. Opr. perg. wsp.

„Remedia efficacissima in malignos spiritus expellendos, facturasque et maleficia effuganda de obsessis corporibus cum suis benedictionibus. Ordo ad faciendam aquam benedictam. Sacerdos indutus sacerdotalibus indumentis vel saltem stola absiolute dicat. Flagellum daemonum".

Inc.: k. 1v: "Exorciso te creatura salis per Deum $X$ diaboli liberet te Deus. Signaculo...", k. $147 \mathrm{v}$.

Reklamanty. Kodeks bez końca $\mathrm{z}$ obszernymi marginesami.

Składki: 18. Ternion 5. Seksternion $1+1 \mathrm{k}$. Pozostałe kwäternıony.

Filigrany: w lewym górnym rogu karty fragment lilil, k. 14.

Oprawa w pergamin półmıękko. Brak sklejanej makulatury okładek. Pergamin silnie zeschnięty, pomarszczony i krótszy od bloku rẹkopısu o $1^{1 / 2} \mathrm{~cm}$. Szycie przez grzbiet, wzmocnione podłożonym paskiem skórzanym, $z$ przeciągnięciem rzemyków pergamınowych. Slady rzemyków do wiązania.

Proweniencja: Biblioteka OO. Kapucynów w Krakowie. Sygn.: LXXV (o. Z. G.).

71. Eac., pol. II pot. XVIII w. $20 \times 12.5 \mathrm{~cm}$. K. 13. Opr. brosz.

1. k. 1-5. "Benedictio aquae sancti Felicis a Cantalicio Capucini ad sanandos oculorum dolores et alias infirmitates quam Sanctus adhibuit adhuc in vita sua".

Inc.: k. 2: „Benedictio supra aquam medicinal[em] s. Felicis $\mathrm{X}$ in honorem s[anc]ti Felicis powinna odprawić, k. 5.

2. k. 6-13v. Variae benedictiones, chartae, atramenti, calami et sigilli.

Inc.: k. 6: „Chartam, atramentum, calamos et stigillum debere $\mathrm{X}$ ex thuris ss. Trium Regum et ex aliis ss. rebus.", k. $13 \mathrm{v}$. 
Rytuał używany przez kapucynów przy poświęcanıu wody św. Feliksa, papieru, piór l pıeczęcı. Pismo trzech rąk. Pierwsza część o mniejszych wymiarach.

Skradkı: 2. 1 ma $5 \mathrm{k}$. Kwaternion 2.

Filıgrany: Tarcza herbowa $\mathrm{z}$ rogıem myśliwskım 1 inicjałami $\mathrm{G}$ R ponıżej herbu, k. 6 .

Oprawa broszurowa.

Proweniencja: Biblioteka OO. Kapucynów. Kralków. Pieczątka okrągla na odwrocie obwoluty frontowej i $k .1 \mathrm{v}, 5 \mathrm{v}, 13 \mathrm{v}$. Sygn: $\mathrm{W} 44 ; 11 \mathrm{~F}-91$.

72. Pol., ruski, łac., niem., grecki. 1785. $20.5 \times 17 \mathrm{~cm}$. K. 369. Opr. sk. wsp.

„Horologion czyli psalmodia Kościoła Wschodniego dla początkujących w czytaniu greckim, polskim, ruskim, niemieckim i łacińskim, zamykająca w krótkości nabożeństwo kanoniczne całodzienne ułożone staraniem xiędza Timotheusza Szczurowskiego ${ }^{47}$ ZSBW rektora Missyi Bialskiej. R[ok]u 1785".

Inc.: k. 9: "Początek północnego nabożeństwa. Królu niebieski $\mathrm{X}$ so bez płotny my łyky tia weły czajuszcze“, k. $344 \mathrm{v}$.

Liturgia wschodnıa dla użytku kapłanów tegoż obrządku. Zawıera pacierze kanoniczne $w$ oryginale i kilku tłumaczenıach oraz wykład służby Bożej. Reklamanty. Oryginalna paginacja rękopısu. Karty niezapisane: 1v, $4 v, 5-8,194,345,346$. 'Tekst w podwójnej ramce, w układzie dwu- 1 trój1 czterokolumnowym, chociaż zdarzają sıę również jednokolumnowe. Nuty od k. 184-344v. Spis treścl: k. 2-4. K. 347-369v: ,Zbıór ımion używalnych greko-ruskıch, łacıńskıch, polskıch w 35 rozdzıałach zamknıęty“. Na karcıe tytułowej napis: „Powlerzona dla wydrukowania JX. Józefow1 Nowakowskiemu 1 JX Bazylemu Połońskiemu. Autor".

Składkı: 91. 48, 50, 52, 68, 71, 75, 77 mają po $2 \mathrm{k}$. Ternony $46,49,53,54$. Kwaternion 1. Pozostale biniony ale $91+1 \mathrm{k}$.

Filıgrany: na wyklejce tylnej nazwa: Neuendorf. Orzel z literą $\mathrm{K}$, w jednym szponie miecz, w drugım jabłko $z$ krzyżem, $k$. 1 . Litera $S, k$. 346. Litera Z, k. 173. Nazwisko: Kraus, k. 228.

Oprawa w szarą tekturę szmacıaną. Grzbiet i okładki obciągnięte sk. cielęca barwioną na brązowo. $\mathrm{Na}$ okładce frontowej 1 tylnej ramki biegnące wokół, tłoczone na ślepo stemple, o rysunku rokokowym, w pośrodku zaś gwıazda złożona $z$ pojedynczych palmetek. Szycie na 4 więzy. Slady dwóch par rzemyków do wıązania. Brzegı nakrapıane na niebıesko.

Proweniencja: 1. Ks. Tymoteusz Szczurowski. bazylianin.

2. O. Wacław Nowakowski. Na odwrocte wyklejki napis: „Rękcpis ze zbioru o. Waclawai".

3. Biblioteka OO. Kapucynów. Kraków. Pieczątka okrągła i owralna na odwrocie wyklejki frontowej i k. 1r, 369v. Sygn.: $22 \mathrm{~J}-102$; Nr LXXXVII (0. Z. G.).

47 Ur. 20 XI 1740, do bazylianów wstąpił w 18 r. zycia, zm. 15 I 1812. - Enc. Now. XXVII 486-488; Enc. Chelm. XXXVII/XXXVIII 367. Es tr. IV 439; XXX 228-231; Enc. Orgelbr. XIV 244; J o cher nr 2607, 7297; Bp B. Sz y máski: Rys historyczny zgromadzeń zakonnych. Warszawa 1848. T. 2 s. $15-17$. 


\section{MIODLITEWNIKI}

73. Łac. $1756.19 \times 11.5 \mathrm{~cm}$. K. 98. Opr. sk. wsp.

"Compendium devotionis quotidianae. A. D. $1756^{\circ}$.

Inc.: k. 1: „O Jesu amantissime, adoro. Te, ut Deum meum $\mathrm{X}$ in $\mathrm{Te}$ Domine speravi et non confundar in aeternum", k. 96v.

Modlitewnik został opracowany przez ks. Joachıma Bończa Brzostowskiego. Właściwy tytuł mieści sıę na k. 12. Tytuł w ozdobnej w.nıetce podtrzymywanej przez dwa anioły. Paginacja oryginalna: 187, nlb. 5. Wlepione druk1 z modlitwamı na k. 1v, 2, 11, 17r, 20r, 28, 33v, 34r, 39, 42r, 61, 62, 30, 81, 82-86r, 94r. Rękop1s bogato zdobiony lıcznymi wycinankamı z druków przedstawıjących sceny z życia Pana Jezusa, Matki Bożej, względnıe ilustrujacych postaci świętych lub symbole religijne.

Składk1: 11. Termıny 2, 7, 9. Kwaterniony 4, 5, 11. Kwinterniony 1, 3, 6, 8, 10. Kustosze literowe od aa-ii.

Filigrany: lilia, k. 76. Napis: Zoon, k. 76. Inıcjały GR, k. 89. Nazwisko: J Honig, k. 94.

Oprawa $\mathrm{w}$ tekturę szarą obciągniętą $\mathrm{w}$ całoścı sk. cielęcą czarną. W polach na grzbiecie ślady napisu tytułowego "Selecta devo[tionis] cot[idianae]", ręcznie tłoczonego oraz bogatego ornamentu. W polach między więzamı cztery kwıatki ze stemplem kwatowym pośrodku. Również na okładkach ramka tłoczona wokół linłjką delikatnym wężykiem, o którą oparty motyw roślinny, powtarzany stemplem, ręcznle tłoczony również na ciemno. A pośrodku inıcjały: J. A. B. Na frontowej okładce od wewnątrz naklejony jako ekslibrıs, wycıęty z drukowanego egzemplarza, herb Bończa a wokół ramki przyklejone powycinane litery J. A. B. F. P. V. Na wyklejkach obrazkı religijne. Nad I pod nimi wystrzygankı papıerowe kolorowane. Szycie na 5 wıęzów. Brzegı złocone.

Proweniencja: 1. „Pro usu R. Joachimi Ant. Bończa Brzostowski“. Napis na k. 12.

2. „Ex libris. Josephus Tarnawski“. Napis na odwrocie okładki frontowej i na k. 1 .

3. Biblioteka OO. Kapucynów. Kraków. Pieczątka okrągła na wyklejce frontowej i k. $96 \mathrm{v}$.

74. Niem. I pot. XVIII w. $15 \times 9 \mathrm{~cm}$. K. 227. Opr. sk. $w s p$.

Gebetsibuich.

Inc.: k. 1: „O Gatt. Ich bitte dich durch deine $\mathrm{X}$ im Frieden ruhen. Amen. Der...", k. 227v.

Rękopis bez karty tytułowej i bez końca. Wykonany niemieckım gotykiem. Reklamanty. Paginacja oryginalna: 5-408. Rubrykowane tytuły i początkı rozdziałów oraz niektóre inıcjały.

Skladki trudne do przeliczenia.

Bez filigranów.

Oprawa w tekturę, cała sk. cıelęca, brązowa. Grzbiet prosty. Szycie na 4 sznurki. Brzegi kolorowane na niebiesko.

Proweniencja: Biblioteka OO. Kapucynów. Kraków. Sygn.: 16 G-81; Nr LXXVI (o. Z. G.).

75. Pol. II pot. XVIII w. $19 \times 21.5 \mathrm{~cm} . K .213$. Opr. sk. XIX $w$. Modlitewnik. 
Inc.: k. 1: „Modlytwa nabożna do Najświętszej Panny Maryjej. Najświętsza Matko, Stolico Mądrości, do Ciebie każdy X na pamiątkę życia swientego Benedykta“", k. 211.

Kodeks bez karty tytułowej i początkowych kart. Dlatego trudno ustalić autora rękopisu. Może nım być 0 . Andrzej Dobrawski ${ }^{48}$, kapucyn lub Wacław Rzewuski z Podhorzec. Naprawdopodobnıej autorem jest raczej osoba świecka, jak można wnloskować z utworu o Matce Bożej. Na treść rękopisu składają się godzinki, modlitwy, lıtanie, psalmy itd. a m. in. „Pieśń o Najśw. Pannie Jurowieckiej“, k. 177-186. Karty niezapisane: 212, 213. Papier w górnej części bloku rękopisu bardzo zmurszały.

Składkı: 47. 41, 47 majaz po $2 \mathrm{k}$. Terniony i9, 43. Kwaterniony 18, 45, 46. Kwinterniony 8, 44. Pozostałe biniony.

Filigrany: zdobnik, k. 14, 15. Myśliwy na koniu, dmący w róg, z lewej strony wysoki krzyż z podwójnym ramıeniem, k. 106, 107. Róg myśliwski, k. 207. Myśliwy na konıu, dmący w róg, k. 199, 200.

Oprawa w deski bukowe obciągnięte sk. cielęca, kolorowaną na brązowo. Grzbıet zamalowany farbą popielatą $z$ napisem tytułowym $w$ górnej części: „Modlutwa". Na okładce frontowej i tylnej rameczka z linii prostych tłoczonych na c1emno, w rogach małe tłoczone rozetki a w pośrodku owalny wianek ze stylizowanych lıścı tłoczonych dawniej na złoto, które dziś jest prawie wytarte. $\mathrm{Na}$ frontowej i tylnej okładce po dwie pary trzech gwoździ, jak gdyby ślady dawnych zapmek lub metalowych okuć. Szycie na 4 sznurki przyklejane od wewnątrz. Kapitałka ręcznie szyta. Brzegi złocone. Wyklejka: papıer czerpany grzebienıowy, lśniący (więc oprawa z XIX w.).

Proweniencja: 1. Biblioteka OO. Kapucynów w Olesku. Pieczątka okrạgła na k. 1, 213v. Sygn.: Z 68 .

2. Bibliotekia OO. Kapucynów. Kralków. Pieczątka okrągła na k. 1, 210v.

76. Pol., zac. II pot. XVIII w. $16 \times 10 \mathrm{~cm} . K$. 66. Opr. sk. wsp.

Miodlitewnik.

Inc.: k. 1: „O misericordissime Domine Jesu per lacrymas tuas X regni da superni nobis terrae incolis", k. 66v.

Rękopis opracowany dwiema rękami. Na wewnętrznych stronach okładek teksty rękopiśmıenne, na frontowej modlitwy w jęz. łac., na tylnej szereg nazwisk nie mających nic wspólnego z proweniencją. Ostatnia karta wyrwana.

Składkı: 8. Seksternion 7. Pozostałe kwaterniony lecz 8 bez $2 \mathrm{k}$.

Filigrany: jak pod nr 82 .

Oprawa w tekturę, obciągniętą sk. cielęcą ściemnioną na brązowo. Wyklejka: papier czerpany ale tylko na wewnętrznych stronach okładek. k. 1,36 .

Proweniencja: 1. Biblioteka OO. Kapucynów w Olesku. Pieczątka okrągła na

2. Biblioteka OO. Kapucynów. Kraków.

77. Pol. 1840. $16 \times 10 \mathrm{~cm}$. Slb. 1068, nlb. 28. Opr. sk. wsp. ,"Zbiór nabożeństw".

18 Ur. 15 XI 1694, do zak. wstąpił 1719, zm. $15 \times 1768$ W Olesku. Budownıczy klasztoru w Olesku. - CPP nr 25; Mortuologium, jw.; O. K. G a d a c z : Inwentarz Archıwum Prowncji Krakowskiej Zakonu OO. Kapucynów. Archiwa, Bibliot. kośc. T. $2: 1961$ z. 1/2 s. 136, 143; St. $€$ oza: Architekc1 \& budowniczowie w Polsce. Warszawa 1954 s. 63. 
Inc.: s. 1: „Wiedzieć trzeba, że przez sferę świata rozumie się X bo przyszedł Syn człowieczy szukać ì zbawić co było zginęło", s. 1068.

$\mathrm{Na}$ wyklejce frontowej napis czerwonym cłówkıem 'z w. XX: „Książka do nabożeństwa". Reklamanty. Ostatnie 9 nlb. niezapisane. Kodeks składa się z dwóch gatunków papieru: białego i kremowego grubszego.

Filigrany: fragment $z$ napisem „Pro Patrıa“, s. 89.

Składki trudne do przeliczenia.

Oprawa w twardą tekturę obcıągniętą w czarną skórę. Na okładce frontowej i tylnej ramka jednolinijna złocona, ze złota bordiurka, o motywach palmetkı i ostroluku w charakterze epoki romantycznej. W narożnikach od środka stempel z motywem kwiatowym. Pośrodku frontowej okładki sztanca $z$ krzyżem w otoku promieni 1 inicjałam $\mathrm{B}$. D. J. K. Na okładce tylnej takıż krzyż $z$ datą 1840. Grzbiet podzielony na pıęć pól poziomymi złoconymi bordiurkamı. W polach stemple ze 'zdobnikiem o motywie roślinnym. W drugim polu od góry tytul. Brzegi czerwone. Wyklejka: papıer zwykły marmurkowy, zielony.

Proweniencja: 1. B. D. J. K. Frontowa okładika.

2. Biblioteka OO. Kapucynów w Krakowie. Sygn.: s-238; $16 \mathbf{E - 3 4}$.

78. Łac., pol. I poz. XIX w. $10.5 \times 8.5 \mathrm{~cm}$. K. 111. Opr. sk. wsp.

Modlitewnik.

Inc.: k. 1: „In nomine Patris, et Filii, et Spiritus Sancti $X$ vivis et regnas in saecula saeculorum. Amen", k. 110.

Karty niezapisane. 17r, 21v, 22, 26v, 29-31r, 95, 102, 104r, 110v-111. Blok rękopisu zlożony $z$ papıeru czerpanego sıwego i białego (k. 17-95). Marginesy 1 liniowanie kart wykonane olówkiem. Wklejone druki z modlitwamı na k. 10v, 17v-21, 32v, 101v. Na obydwóch wyklejkach nalepione drukı z modlitwamı.

Składkı: 7 seksternionów.

Filigrany: fragment filigranu w górnym prawym rogu karty. Motyw roślınny, k. 104. Litera A i napis Socz, k. 106. Fragment napisu: D T, Wka, k. 109. Jeleń duży w biegu, k. 110.

Oprawa w tekturkę, obciągnięta skórą barwioną na czarno. Na grzbiecie ornament tłoczony na ciemno liniami prostymi. Na okładkach rameczka tłoczona wokół rolką z motywem linearnym, pośrodku pola na frontowej okładce tłoczony sztancą krzyż stylizowany z promieniami i podstawą oraz inıjałami: $u$ góry $X$, po bokach: O.J.L.K. Taki sam krzyż powtórzony na tylnej okładce. $\mathrm{Na}$ obu okładkach naklejone obrazki religijne. Szycie na 3 sznurki. Brzegi barwione na żółto.

Proweniencja: Biblioteka OO. Kapucynów. Kraków. Sygn.: 17 A-22.

79. Eac. I pot. XIX w. $20.5 \times 12 \mathrm{~cm}$. K. 128. Opr. płpł. XX w. „Preces..."

Inc.: k. 1: „Experrectus surge alacriter, et frontem $\mathrm{X}$ et oprimas me opus manuum tuarum, et...", k. $127 \mathrm{v}$.

Kodeks zawiera różne modlitwy i jedną $\mathrm{k}$. drukowana (128) z „Oratio ad sacratissimum Cor Jesu". Reklamanty. Paginacja oryginalna: 242, nlb. 16. Karty niezapisane: $61,62,63,64 \mathrm{r}, 112,113$. Karty doklejane: $61-64,112,113$. 
$\mathrm{Na}$ frontowej wyklejce napıs: „Non nobıs Domine non nobis, sed nomini Tuo da gloriam“ i „Oprawiłem własnoręcznie 1906. Ladislaus Rożek“ (nazwısko nieczytelne).

Składki: 64 bınıony.

Filigrany: napıs: G Sieber, k. 2; Janowitz, k. 9, 10.

Oprawa w tekturkę. Grzbiet i rogi plótno wiśniowe kaliko. Okładki obciągnięte papierem marmurkowym fabrycznym, niebıeskım. Szycie na 2 tasiemki.

Proweniencja: 1. Ladislaus Rożek (?).

2. Biblioteka OO. Kapucynów. Kraków. Pieczątka poidłużna na wyklejce frontowej i k. 127v, 128v. Sygn.: S - 996; $15 \mathrm{~K}-7$.

80. Pol. I pot. XIX w. $17.5 \times 11 \mathrm{~cm}$. K. 10. Bez opr.

"Cwiczenia pobożne dziewięcio albo trzydniowe do ś[więt]ej Weroniki de Giuliani kapucynki"“.

Inc.: k. 1: „Otwórz Panie usta nasze na ubłogosławienie X chwałe i zbawienie du'sz naszych. Amen", k. 10v.

Składki: 1 kwınternıon.

Filigrany: na k. 5v pieczątka tłoczona na sucho $\mathrm{z}$ monogramem $\mathrm{H}$ L i koroną ponad nimi, poniżej dwie skrzyżowane gałęzıe i inicjały.

Proweniencja: Biblioteka OO. Kapucynów. Kraków. Sygn.: s--243.

81. Pol. 1870. $20.5 \times 13 \mathrm{~cm}$. Snlb. 8, 208, 6. Opr. sk. wsp.

"Wybór modłów zebranych z rozmaitych książek nabożnych".

Inc.: s. 1: „Potrzeba idąc za radą mędrca uprzedzać modlitwą X orzyczyń się za nami do Syna swojego. Amen“, k. 208.

Rękopıs wykonany jedną ręką. Zaopatrzony w skorowıdz. Na k. tytulowej objaśnienie: „Na pamıątke czterdzıesto-pıęcioletniego pożycıa małżeńskiego napısał tę książkę $1870 \mathrm{r}$. wdzıęczny mąż Filip dla swej ukochanej i zacnej żony Anny Zawadzkiej na dzıeń jej ımienia 26 lipca 1870 r.". Pod tytułem nalepiony kwiatek $w$ kolorze szarym $z$ inicjałami: A. Z. Tytuł i. dedykacja ujęte w piękną nalepioną ramkę.

Oprawa w twardą tekture obciągniętą w brązowo-jasną skórę chagraın. $\mathrm{Na}$ frontowej okładce lekko wypukło traktowana podwójna ramka. W pośrodku zwierciadła również wypukły krzyż w obramowaniu kompozycjı francuskiej z końca XVI w. Pod kantami i na kantach złocenıa bordiurek. $\mathrm{Na}$ tylnej okładce litery A. Z. i data 1870. Na grzbiecie tytuł złoccny: "Wybór modłów". Szycie na 4 więzy. Brzegı złocone j. polerowane.

Proweniencja: 1. Anna Zawadzka.

2. Biblioteka OO. Kapucynów. Kraków. Pieczạtka owalna na k. tytułowej. s. 84, 208; okrągła na wylklejce frontowej. Sygn.: s-1030; $15 \mathrm{~K}-8$.

\section{TEOLOGIA ASCET'YCZNA I MISTYCZNA}

82. Wloski. 1675. $15 \times 9.5 \mathrm{~cm}$. K. 68. Opr. brosz. wsp.

„Humili et divote meditationi composte dal S. Tomaso de Kempis, necessarii ad'ogni Christiano, che desideri di vivere secondo la sua santa fede. Copiato in Craccovia nell'anno MDCLXXV". 
Inc.: k. 3: „Signor Iddio mio, tu sei ogni mio bene $\mathrm{X}$ et di petto et doppo questo pace di eternità. Amen", k. 60v.

Rękopis w języku włoskim napisany w Krakowıe. Reklamanty. Karty niezapisane: 1v, 2, 61-68.

Składki: 10. Binion 1. Terniony 2, 10. Pozostałe kwaterniony.

Filigrany: fragment niezidentyfikowanego filigranu w lewym górnym. rogu karty.

Oprawa w papier sklejany, obciągnıęty papierem czerpanym barwionym na czerwono. Brak grzbietu. Szycie na 2 sznurki.

Proweniencja: Biblioteka OO. Kapucynów. Kraków. Sygn.: $16 \mathrm{H}-65$.

83. Łac. I pot. XVIII w. $16 \times 9.5 \mathrm{~cm}$. K. 175. Opr. ptsk. wsp.

1. k. 1-112. Exercitia divina. Authore Nicolab Eschio.

Inc.: k. 4: „Primo exercebis te in forti, perfecta $X$ ad laudem Dei sublimis et gloriosi in saecula benedicti. Amen", k. 111.

2. k. $112 \mathrm{v}-171$. „Practica pretiosae mortis".

Inc.: k. 112v: „Rex omnipotens Jesu Fili Dei cui omnia X voluntatem resignet et spiritum suum ipsi commendet", k. 170.

Rękopis wyszedł spod trzech rąk. Trzecia ręka dopisała dodatek na k. $170 \mathrm{v}, 171$. Reklamanty. Druga część posiada oryginalną paginację: nlb, 5, 111 , nlb. 11. Karty niezapisane: $171 \mathrm{v}-175$. Glosy marginalne. „Index paragraphorum" na k. 114.

Składki: 13. Binıon 1. Kwaterniony 2, 3. Pozostałe okterniony lecz 13 bez $3 \mathrm{k}$.

Filigrany: jak pod nr 82.

Oprawa $w$ tekturkę, obciągniętą wąską skórką w grzbiecie i rożki barwione na brązowo, z naklejonym szyldzikiem ze skórki jasnej i tłoczonym napısem czarną farbą, natomiast grzbiet złocony $w$ całości stemplem $z$ motywem meandra. Okładki obciaggnięte papierem klajstrowym jasnobrązowym. Szycie na 2 sznurkı. Brzegi czerwone.

Proweniencja! Biblioteka OO. Kapucynów $w$ Krakowie. Pieczattka owalna na frontowej wyklejce. Sygn.: Sub Litt. D No 12: s-340; $14 \mathrm{E}-23$.

84. Eac. 1769. $16 \times 9.5 \mathrm{~cm}$. K. 61. Opr. ptsk. wsp.

„Rudimenta religiosa quibus novitii et neoreligiosi pie erudiuntur in quotidianis exercitiis spiritualibus perficiendis. Libellus praesens complectitur omnia et singula exercitia spiritualia in religione nostra usitata nec non salutaria documenta, pia monita et vitae regularis observantia. A. 1769 die iunii“".

Inc.: k. 1v: „Charissimi fratres. Trado vobis rudimenta $\mathrm{X}$ nam de hac praeparatione loquebantur", k. 60v.

Podręcznik dla nowicjuszy kapucyńskıch opracowany przez o. Kajetana Cyglera ${ }^{49}$, mistrza nowicjatu. Reklamanty. Karty niezapisane: 61 . Inskrypcja

40 Ur. 9 III 1739, do zak. Wstąpił 1759, zm. 14 II 1812. Prowincjal prowmcji polskiej 1 kustodii Galicji Zachodniej, pisarz. - CPP nr 254; Mortuologium, iw.; O. Z. GorI 1 ck1, jw. s. 274-281; Es tr. XIX 14. Nazwisko róznie pisane; Es tr. - Zyller, O. Gorlickı Zygler, CPP - Zyker, mnı - Cygler. 
na odwrocie okładki frontowej: „Liber scriptus sub AVP. Caietano Vicario et Magistro Novitiorum Lubart[oviae]".

Składkı: 8. Ternıon 1. Pozostałe kwaterniony lecz 8 bez $2 \mathrm{k}$.

Filigrany: jak pod $\mathrm{nr}$ 82. Matka Boska $\mathrm{z}$ Dzieciątkiem w koronach, k. 20. Litera $N$, k. 61. Zdobnik na wyklejce tylnej.

Oprawa półmiękka w tekturkę sklejaną z makulatury zadrukowanej. Grzbiet i rogi obciagnięte sk. brązową. Papier klajstrowy marmurkowy.

Proweniencja: 1. „Pro usu fratris Macarii [Drabowicz] clerici Capucini“. Napis na odwrocie olkładki frontowej.

2. Biblioteka OO. Kapucynów. Kraków. Sygn.: 16 F-23.

85. Pol. 1791. $20.5 \times 13.5 \mathrm{~cm}$. K. 24. Bez opr.

„,Rozmowa ducha, nozważanila zakonnego z piącią zmysłami oraz pielgrzymowantia lub podróż tyłchże zmysłów w kriainie ciemności“".

Inc.: k. 1: „Zmysły kochane. Kochani bracia beniaminowie $\mathrm{X} z$ tych zwyczajów na tobie nie widać. Osob. Duch. dn. 8 ćwicz. poranne“, k. 24v.

Rękopıs opracowany przez o. Firminiana Kuzela ${ }^{50}$, Czecha. Napis na obwolucie frontowej: ,Manuscripta Pris Firminiani Capucin concionatoris. Spiritualı. Qui obiit Crosnae anno Dnı 1791“.

Składkı: 3 kwaterniony przyszyte do papıerowej obwoluty.

Filigrany: tarcza herbowa $z$ rogıem myśliwskim w polu, k. 9, 22. Lilia, k. 24.

Proweniencja: Biblioteka OO. Kapucynów. Kralków. Pieczątka na k. 1, 24v. Sygn.: S- 239; $16 \mathrm{~L}-12$.

86. Pol., łac. II poł. XVIII w. $16 \times 10 \mathrm{~cm}$. K. 58. Opr. sk. wsp.

Podręcznik ascetyczny dla nowicjuszy kapucyńskich.

Inc.: k. 1: "Wziąwszy benedykcyją od magistra pójdziesz $\mathrm{X}$ et per te caepta finiatur. Per Christum Dominum nostrum. Amen", k. 52.

Rękopıs bez tytułu, początku i końca. Reklamanty. Karty niezapisane: $52 \mathrm{v}, 53-58$. Blok rękopısu lekko zawilgocony. Na odwrocie okładki frontowej tytuł (XX w.): „Książka pouczająca dla zakonnika Kap“.

Składkl: 8. Binion 8 bez 2 k. Pozostałe kwaterniony.

Filıgrany: Matka Boska z Dziecıątkıem, fragment filigranu w górnym lewym rogu karty.

Oprawa w tekturkę półmiękką, obciągniętą w całą sk. cielęcą barwıoną na brązowo. Szycie na 2 paski pergaminowe.

Proweniencja: Biblioteka OO. Kapucynów w Krakowie. Pieczątka owalna na adwrocie okładki frontowej. Sygn.: 17 D - 21. S-857.

87. Pol. II. pot. XVIII w. $16.5 \times 10 \mathrm{~cm}$. K. 183. Opr. sk. wsp.

Rozmyślania dla osób zakonnych.

Inc.: k. 1: „szy Ojcze, bądź mi Ojcem, i przemień mię $\mathrm{X}$ na zbawienie dusz ludzkich i twoję ponętę", k. 182v.

Rękopis bez początku, brakuje pierwszej składki (kwaternıon). Jest to prawdopodobnie kopia ze współczesnego druku. Swiadczy o tym napis na

so Ur. 9 I 1734, do zak. wstąpił 1753, zm. 13 II 1791 w Krośnie. - CPP nr 178: Mortuologium, jw. 
k. 180: „Już więcej nikomu pisać nıe będę. X. D. B. mp.“. Reklamanty. Blok rękopısu od strony brzegu lekko zawilgocony.

Składki: 23 kwaterniony lecz 1 bez $1 \mathrm{k}$. Kustosze literowe: od B-Y.

Filigrany: Matka Boska z Dzıeciątkiem wsparta o półksıęzyc, k. 18. Zdobnik z inıcjałami I H S, k. 25, 26, 29.

Oprawa w deski obciągnięte sk. cielęca, barwioną na brązowo. Na okladce frontowej a tylnej ramka na ciemno tłoczona recznie stemplami powtarzającymi sıę o motywie kwiatu. Na grzbiecie ślady 3 więzów, skóra silnie popękana. Brzegi nakrapıane na niebıesko.

Proweniencja: Biblioteka OO. Kapucynów, Kiaków. Sygn.: 16 E-18.

88. Łac. II pot. XVIII w. $13 \times 7.5 \mathrm{~cm}$. K. 92. Opr. brosz. wsp.

Meditationes.

Inc.: $k .1$ : „Praeludium 1. Canstitue te per actum fidei ante $\mathrm{X}$ per Mariam et eirus filium", k. 79.

Bez karty tytułowej. Reklamanty. Karty niezapisane: 79v-92. Slady zawilgocenia od strony grzbietu.

Skladki: $4 \mathrm{k}$. ochr., 23 biniony.

Filigrany: fragment korony pięciopałkowej, k. 79.

Oprawa w sklejaną makulaturę, obciągnięta papierem czerpanym z resztk druku kwiatowego, kolorowego. W grzbiecie brak papieru. Szycie na 3 sznurki, wzmocnione w grzbiecie szarym płótnem, znacznie zniszczonym.

Proweniencja: 1. Biblioteka OO. Kapucynów w Olesku. Pieczątka okrągla na k. 1 i 32.

2. Biblioteka OO. Kapucynów. Kraków. Pieczątka akrągła na k. ochr. i 79.

89. Łac. II poł. XVIII w. $18.5 \times 11 \mathrm{~cm}$. K. 93. Opr. brosz. wsp.

1. k. 1-62. „Certamen spiritualis".

Inc.: k. 1: „Brevis notitia vitae V. P. ac Dei servi Laurentii Scupoli $\mathrm{X}$ pugnabis contra eos usque ad internecionem. 1 Reg. 15“, k. 59.

2. k. 63-93. „Adidita certramini spirituali“.

Inc.: $\mathrm{k}$. 63: Quid sit Xristiana perfectio? Dilecte fili $\mathrm{X}$ atque ad se brevi temporis spatio ditandam", k. 91.

Rękopis zawiera przepısane dzıeło ascetyczne Wawrzyńca Scupoli, teatyna. Reklamanty. Pagınacja orygınalna: 116 , nlb. 8; 57, nlb. 5. Spis treśc1: k. $59-62,91 \mathrm{v}-93$.

Składki: 12. Binion 2. Kwınternıony 5, 12 bez $3 \mathrm{k}$. Pozostałe kwaterniony.

Filigrany: jak pod nr 82.

Oprawa w tekturkę z szyciem przez grzbiet.

Proweniencja: Biblioteka OO. Kapucynów w Krakowie. Sygn.: LX (o.Z. G.).

90. Eac. I pot. XIX w. $15.5 \times 9.5 \mathrm{~cm}$. K. 172. Opr. sk. wsp.

„Capucinus solitarius“.

Inc.: $\mathrm{k}$. 1v: „Deus qui te diligentibus omnia $\mathrm{X}$ talia peccando generantur et prodeuntur", k. 131 . 
Zbiór rozmyślań dla zakonników przepisany i zebrany przez br. Juliana Kielnara ${ }^{51}$, kapucyna. Karty niezapısane: 2v, 123v, 124v, 131v-172. Paginacja oryginalna doprowadzona do k. 72. Spis treścı: k. 75v, 124. Na marginesach numery paragrafów.

Składki: 23. 1 ma $2 \mathrm{k}$. Binion 19. Terniony 4, 6, 9, 12. Kwaterniony $3,7,10,13,14,15-18,20-23$ lecz 23 bez $3 \mathrm{k}$. Kwinterniony 2, 5, 8, 11 .

Filigrany: w lewym górnym rogu karty fragment filigranu. Fragment tarczy herbowej z koroną, k. 140. Niewiasta z bukietem kwiatów, mężczyzna zapewne z kielichem, k. 158, 169.

Oprawa w tekturę obciągniętą $w$ całośc1 w sk. brązową, marmurkowaną na brązowo. Szycie na 2 sznurki. Kapitałka wklejona. Brzegi nakrapiane na niebiesko.

Proweniencja: 1. „Ad simplicem usum F. Juliani"s. Napis na k. 1.

2. Bibliateka OO. Kapucynów w Olesku. Pieczątka okrągła na k. 1, $131 \mathrm{v}$.

3. Biblioteka OO. Kapucynów. Kraków.

Uwagi: Rkps jest streszczeniem dzieła pt. Capucinus solitarius per decem dies meditans sive exercitia spiritualia accomodatı ad usum $F$. F. Minorum $S . P$. Francisci Capacinorum ante hac a $R$. P. Maria a Bergamo Capucino Prov. Bresciae concionatore, italico idiamate in lucem data. Nunc post quintam editionem ob summam utilitatem a quodam eiusdem ordiris, et Provinciae Bavaricae sacerdote iatine reddita. Monachii typis Joannis Vötter 1755. Druk znajduje się w Bibliotece OO. Kapucynów w Krakowlie; sygn. 7860. Na k. tytułowej podpis: „F. Juliani“. Na wyklejce frontowej napis: "Concessus pro simplici usu P. F. Juliani...". Napisy wykionane ręka autora rękopisu.

91. Pol. 1820. $19.5 \times 11 \mathrm{~cm}$. K. 634. Opr. ptsk. wsp.

„Źywot Pana i Boga naszego czyli droga zbawienia, którą Pan Zbawiciel i Odkupiciel nasz Jezus Chrystus za przyjściem swoim na świat dla odkupu i wybawienia z mocy szatańskiej rodzaju ludzkiego, będąc jako się sam mianował u Jana Ewan[gelisty] w Roz. 14: Drogą, Prawdą i Żywotem. Dla użytku zbawiennego i codziennej świątobliwości z Bogiem rozmowy i zabawy. Przepisany ode mnie Ma. Len. w Warszawie die 27 martii anno Dni 1820. MDCCCXX. Błogosławiony człowiek, który tę książkę czyta, i co w niej napisano naśladuje“.

Inc.: k. 1v: „Bądź wdzięczen pobożny Czytelniku, ażebyś X mamy, znosząc, ile można grzechowe długi“, k. $623 \mathrm{v}$.

Rękopis przepisany prawdopodobnie $\mathrm{z}$ druku współczesnego. Paginacja oryginalna: nlb. 8, 1109. Spis treści: k. 624-633. Karty niezapısane: 633v, 634. W tekście liczne wlepione wycinankı, ręcznıe kolorowane a służące dla ilustracji omawianych zagadnıeń. Równieź liczne wklejki większego formatu, wycięte $\mathrm{z}$ druków niemieckich 1 z niemieckımı napisami; otrzymały one bieżącą foliację. Od. k. $493 \mathrm{v}-623 \mathrm{v}$ znajduje się krótkı katechızm przedstawiony w pytaniach i odpowiedziach.

Składki: 71 kwaterniony ale 71 bez $3 \mathrm{k}$.

Filigrany: w lewej górnej części karty fragment niezıdentyfikowanego filigranu. Nazwisko: J Honıg, Zoonen, k. 633, 634.

Oprawa w tekturę szarą. Grzbiet i rogi obciągnięte sk. cielęcą barwioną

st Ur, 12 VII 1865, do zak. wstąpil 1883. Usunięty z zakonu, zapısał się do wojska. Kartoteka autora. 
na brązowo. Okładkı obcıągnięte papierem czerpanym barwionym na granatowo. W grzbiecıe, wskutek częstego używanıa rękopıs zalamany do środka. $\mathrm{Na}$ okładce frontowej od wnętrza naklejone wycinanki z postaciami i symbolamı czterech Ewangelistów. Wszystkıe ręcznie kolorowane, w pośrodku obrazek $z$ podpisem $u$ dołu: Pastor Bonus, otoczony ramką prasowanego papieru w kształcie gwiazdy $\mathrm{z}$ wycięciem owalnym. $\mathrm{Na}$ okładce tylnej naklejony obrazek, znıszczony u dołu (może litografia), ze sceną wojenną wodza na koniu na tle miasta $\mathrm{z}$ katedrą (Sobieski pod Wiedniem?). Szycie na 3 sznurki.

Proweniencja: 1. „Ma. Len“. Napis na k. 1.

2. Biblioteka OO. Kapuicynów. Kraków. Piecząlka okrągła na odwrocie olkładiki frontowej i k. 633. Sygn.: $16 \mathrm{H}-12$; Nr LII (o. Z. G.).

Uwagi: rkps w zasadzie oparty na druku: Zywot Pana $i$ Boga naszego Jezusa Chrystusa. Eowicz 1790 (przedruk). Bibl. OO. Kapucynów w Krakowie. sygn. 9019. Druk nie zawiera ani przykładów, ani katechizmu.

92. Pol. I pot. XIX w. $21.5 \times 17^{`} \mathrm{~cm}$. K. 152. Bez opr.

Rozmyślania na podstawie Nowego Testamentu.

Inc.: k. 1: „To na nas opieranie się nie bacząc $X$ zwracać zacznie na nas dawnych uwrage", k. $152 \mathrm{v}$.

Pismo jednej ręki, bez początku i końca. Papier czerpany, siwy.

Składki: 38 binionów.

Filigrany: Matka Boska z Dziecıątkıem w koronıe w otoku promieni, stojąca na półksıęzycu, ponad nią równoramıenny krzyżyk, $k$. 2, 3. Nazwa: Breslau, k. 9, 12. Inıcjały F W W, k. 46, 47. Zdobnik a ponıżej napis: Filehne. k. 114, 115. W owalu ozdobnym prawdopodobnı postać Matkı Boskiej $\mathrm{w}$ koronie $\mathrm{z}$ inicjałamı I O, a poniżej owalu nazwa: Krzeczow, k. 133-136.

Proweniencja: Biblioteka OO. Kapucynów w Krakiowie.

93. Pol. 1880. $17 \times 10 \mathrm{~cm}$. K. 80. Opr. ptpt. wsp.

Czytanka majowa.

Inc.: k. 3: „Bardzo wiele mamy przykładów w Piśmie św. X powiedział do uczniów: żal mi tego ludu", k. 80v.

Karty niezapisane: 1, 2r, $16 \mathrm{v}, 23,29 \mathrm{v}, 50 \mathrm{v}, 61 \mathrm{v}, 62$.

Składki 4. 1 ma 17 k., 2-22, 3-22, 4-20.

Oprawa kajetowa w tekturkę $z$ grzbietem, w czarne płótno. Okładki obciągnıęte czarnym papierem chagrain.

Proweniencja: Bibłlioteka OO. Kapucynów. Kraków. Sygn.: 18 F-41.

94. Łac., pol. 1882. $16.5 \times 10 \mathrm{~cm}$. K. 161. Opr. ptpł. wsp.

„Documenta prima et magis necessaria. Documenta pro tironibus in prima probatione versantibus".

Inc.: k. 1: „In quo corrigit adolescentior viam suam $\mathrm{X}$ az go wprowadzę do domu matki mojej. 4", k. $82 \mathrm{v}$.

Blok rękopısu złożony ze zwykłego papıeru białego, zapısanego do k. 82 v i $153 \mathrm{v}-156 \mathrm{v}$, pozostałe karty niezapisane. Tekst od k. $153 \mathrm{v}$ zawiera „Krótki wykład reguły św. Ojca Franciszka".

Składkı: 8, 1 ma $17 \mathrm{k} ., 2-22,3-26,4-18,5-6$ 1 7 po 22, 8-18. 
Oprawa brulionowa $\mathrm{z}$ grzbietem płóciennym, obciągnięta papierem marmurkowym z końca XIX w.

Proweniencja: Biblioteka OO. Kapucynów w Krakowie. Pieczątka owalna na wyklejce frontowej, $k .82 \mathrm{v}, 160$. Sygn.: $\mathrm{S}-1038 ; 15 \mathrm{H}-2$.

95. Pol. 1898. $21 \times 16.5 \mathrm{~cm}$. K. 138. Opr. brulionowa wsp.

„Zegar pasyjny czyli rozmyślania i wrażenia o cierpieniach Jezusa Chrystusa przez S. A. de Liguori tłomaczone $z$ włoskiego przez Mr Gaume pronotariusza apostolskiego, thomaczone $z$ francuskiego przez F. L. d. $14 / 198^{\prime \prime}$.

Inc.: k. 2: „Powiedziano o »Odwiedzeniach Najświętszego Sakra-mentu« św. Alfonsa $X$ na posiadanie Ciebie w ojczyźnie niebieskiej. Tak nilech się stanie", k. 137v.

Oprawa brulionowa z grzbietem płóciennym, obciągnięta papıerem czarnym chagrain.

Proweniencja: Biblioteka OO. Kapucynów. Kraków. Sygn.: S 215; $16 \mathrm{~K}-25$. BIBLISTYKA

96. Łac. II pot. XVII w. $20 \times 14 \mathrm{~cm}$. K. 81. Bez opr.

„S. scriptura Veteris Testamenti et Novi“".

Inc.: $k$. 1: „,De divina librorum Veteris Testamenti inspiratione $\mathrm{X}$ aut unum tantum evasisse $a b$ incendio arbitrantur", k. 79v.

Reklamanty. Karty niezapisane: 1v, 80, 81. Slady zawilgocenia od strony grzbietu.

Składkı: 6. Seksterniony 1, 3-6. Okternion 2. Kustosze lıczbowe od 1-6.

Filigrany: w kole gołąbek na potrójnym postumenciku, powyżej koła mała korona, $\mathrm{k} .1,12$. W kole gołąbek na potrójnym postumenciku $\mathrm{z}$ inıcjałamı GS, ponıżej litera F, k. 2, 11 .

Proweniencja: Biblioteka OO. Kapucynów. Kraków.

97. Eac. II pot. XVII w. $19.5 \times 13.5 \mathrm{~cm}$. K. 112. Bez opr.

"Institutionum biblicarum pars secunda. De libris Novi Testamenti".

Inc.: k. 1: „Biblicas hasce nostrias institutiones bifariam X Novi Testamenti libris disputaturos permisimus", k. 111v.

Karty niezapisane: 91v, 112. W dolnej części grzbietu ślady dawnego zawilgocenia a od 4 składkı zawilgocenıe widoczne wzdłuz całego grzbietu.

Składki: 14 kwaternionów. Kustosze kombınowane od Script. C 1 Scr. C XIV.

Filıgrany: gołąbek $\mathrm{w}$ owalu na potrójnym postumenciku, ponad owalem litera F, k. 1, 8 .

Proweniencja: Biblioteka OO. Kapucynów. Kraków. Sygn.: A 1 na k. 1. HISTORIA KOŚCIOEA

98. Pol. 1662-1771. $19 \times 14.5 \mathrm{~cm}$. K. 195. Opr. aksamit wsp. „Compendium abo zbior wszy[st]kich (przekreślone) niektórych cudów, darów, łask i dobrodziejstw doznanych przy cudownym obrazie 
Panny Przenas. Panny Czystej a Niepokalanej Mariei w kościele S. Michala Archanioła od dawnego czasu będącym spisany. W Wilnie anno 1662 die 29 septs".

Inc.: k. 2: „Prawdziwa to jest rzecz i nie omylna, iź gidy... X Rotmist[rz] Francliszek Sankowrski Ratm. W[ojewództw]a Trockiego", k. 132.

Kronika łaskami słynącego obrazu Matki Bożej w kościele św. Michała w Wilnie (PP. Bernardynek) założona w r. 1662 przez kapelana sıóstr o. Aleksego Maryna, bernardyna. Obejmuje opıs obrazu a następnie w porządku chronologicznym podaje otrzymane przez wiernych laski od r. 1606 do 1771 . O. Aleksy wpisał do kroniki łaskı otrzymane przed r. 1662, względnıe podpisywał zapisane łaski; późnıej są podpisy innych bernardynów, jak téz inny charakter pısma. Do frontowej wewnętrznej okładkı przyklejona luźna kartka z opisem cudownego zjawienia się krzyża na niebie w Wilnie dnia 19 listopada 1766 r. Karty końcowe kodeksu wyrwane.

Paginacja oryginalna: nlb. 10, 320, nlb. 20. Karty niezapisane: $1 \mathrm{v}, 5 \mathrm{v}, 71$, $84,85,86 \mathrm{v}, 90 \mathrm{v}, 91,95 \mathrm{v}, 106 \mathrm{v}, 124 \mathrm{v}, 128,132 \mathrm{v}-195$.

Składki: 25. 1 ma $2 \mathrm{k}$. Binion $4+1$. Terniony 2, 6, 8, 15 bez $1 \mathrm{k}$, $17,18,20$ bez $1 \mathrm{k}$. wyciętej, 22, 24, 25+2 k. Kwaterniony 3, 7, 10-14, 16 . Kwinterniony 5, 9, 19, 21, 23.

Filigrany: orzel $\mathrm{w}$ owalu $\mathrm{z}$ mieczem $\mathrm{w}$ szponach ponad owalem jabłko z krzyżykiem, k. 5, 6. Większy orzeł polskı w ozdobnym otoku, k. 85. Duży orzeł polski bez owalu na wyklejce frontowej.

Oprawa $\mathrm{w}$ deski, obciągnıęte aksamıtem jedwabnym wiśniowym (bordeaux). Oprawa silnie zniszczona, aksamıt bardzo wytarty, szczególnie na froncie oraz silnje zniszczony grzbıet. Szycie na 3 więzy. Slady rzemyków do zapinania oraz jeden gwóźdź na frontowej okładce. Brzegi ręcznie złocone. Wyklejka z papieru czerpanego, zaklejona powtórnie dla wzmocnienia takim samym papierem a nadto, jako wzmocnienie pęknıętych deseczek, wklejonym od środka paskiem skórkı bıałej ırchowej, tak na frontowej jak i tylnej okładce.

Proweniencja: 1. Klasztor PP. Bernardynek. Wilno.

2. O. Wacław Nowakowski, kapucyn. W rękkopisie zakładka z napisem ręką o. Wacława: „Wilno - św. Michał". Relkopis pochodzi z jego zbiorów.

3. Biblioteka OO. Kapucynów. Kraków. Pieczątka owalna na k. 1, 103, 120v. Sygn.: d 34.

99. Łac. 1697. $20 \times 15.5 \mathrm{~cm}$. K. 165. Opr. sk. wsp.

„Synopsis chronologica rerum eclesiasticarum".

Inc.: k. 1: „1723. Cainam iunior suscipit sale. Ibidem X Ianitor rex Bohemiae Pincerna est", k. 165.

Reklamanty i poprawki w tekście. Liczne zestawienia i wykazy. Tekst. jednokolumnowy w podwójnej ramce do k. 48, później w pojedynczej. Tytuł odtworzony na podstawie podtytułów z k. 63v, 74, 83v itd. Tytuł „Liber historiarum", widniejący na odwrocie frontowej okładki i na k. 1, pochodzi od innej ręki, zapewne Stanisława Kruszyńskıego i został dodany w kilkadziesiąt lat późnıej po napisaniu rękopisu. Manuskrypt zdefektowany, bez kart początkowych. Zawiera historię ludzkoścı od początku do r. 1697. Ta bowiem data podana jest na k. 155v przy królu Auguście II. Daty koronacji 
Augusta III a Stanisława Ponıatowskıego wpisała juz później inna ręka. Również dane $z$ hıstorı powszechnej zostaly zakończone na dacie 1689 (k. 155). Składkı: 42 binıony. 15 bez 1 k. 42 liczy tylko $2 \mathrm{k}$.

Filigrany: tarcza herbowa z koroną (w połowie tarczy pół orła), k. 13, 16. Inicjały MI, k. 30, 31. Zdobnik o motywach roślınnych z krzyżem, k. 164, 165.

Oprawa półtwarda w tekturę szmacianą szarą, w całą sk. cielęcą barwioną na brązowo. Szycie na 3 sznurki. Kapıtałka naklejana. Brzegi nakrapıane w kolorze czerwonym i niebieskim.

Proweniencja: 1. „Ex likris Michaelis Kruszyński Camerarii Sand[ecensis] oblatus", k. $165 \mathrm{v}$.

2. Stanisław IKruszyński. Napis na odwrocie okładki.

3. Biblioteka OO. Kapucynów w Krakowie. Pięczęć owalna i akrągła na odwrocie okładki frontowej, k. 1, 165v. Sygn.: 31 F-23; Nr XXV (o. Z. G.).

100. Eac. II pot. XVII w. $19.5 \times 13.5 \mathrm{~cm}$. K. 186. Bez opr.

Historia ecclesiastica.

Inc.: $\mathrm{k} .1$ : „Quo tempore divinus hominum reparator Christus $\mathrm{X}$ studiosum anno donis sit in sequentibus illustrabimus", k. 183v.

Historia Koścıła; obejmuje trzy plerwsze wiekı. Napisana na papierze włoskım i prawdopodobnie w jednym $z$ tamtejszych semınariów. Reklamanty. Paginacja orygınalna: 366 , nlb. 6. Karty niezapısane: 184-186. Nieliczne poprawki w tekścıe. Glosy margınalne bardzo rzadkıe.

Składkı: 23. Ternıon 13. Kwinterniony 9, 16. Pozostałe kwaterniony. Kustosze literowe od $\mathrm{A}-\mathrm{Z}$.

Filıgrany: gołąbek na potrójnym postumenciku $w$ kole $z$ inıcjałami G $S$, pod kołem litera $F, k$. 1, 8. W tarczy inicjaiy $G G$, pod tarczą litera $F$, k. 20, 21. Gołąhek w kole z inicjałami G I, pod kołem litera F, k. 27, 31 . W tarczy herbowej $\mathrm{z}$ koroną gołąbek stojący na potrójnym postumenciku, k. $181,184$.

Proweniencja: Biblioteka OO. Kapucynów w Krakowie.

101. Łac. II pot. XVII w. $20 \times 14 \mathrm{~cm}$. K. 204. Bez opr.

Historia ecclesiastica.

Inc.: k. 1: „Dixtimus Mancellinum anno huius saeculi $\mathrm{X}$ epulonss reliquit Deus Moysem et prophetas", k. $201 \mathrm{v}$.

Historia Kościoła; obejmuje 4 i 5 wiek. Napisana przez jednego ze studentów teologii na włoskim papierze i w jednym $z$ seminarıów teologicznych tego kraju. Reklamanty. Karty niezapisane: 202-204. Nieliczne poprawkı w tekście. Glosy marginalne bardzo rzadkı.

Składki: 25. Seksternion 2. Pozostałe kwaterniony. Kustosze literowe od $\mathrm{Aa}-\mathrm{Bbb}$.

Filigrany: gołąbek na potrójnym postumenciku w kole z inicjałamı G I, ponıżej koła litera $F, k$. 2, 3. W kole gołabek na potrójnym postumenciku, k. 63, 66. W ozdobnej winietce napis: Fioriny, k. 64, 65. W tarczy herbowej goląbek w pozycji stojącej na potrójnym postumenciku, $\mathrm{k} 104,105$. Gołąbek na potrójnym postumenciku w kole $z$ inicjałami $G S$, pod kołem nie ma zadnej litery, k. 200, 201.

Proweniencja: Biblioteka OO. Kapucynów w Krakowie. Sygn.: H 5. 
102. Eac. II pot. XVII w. $19.5 \times 14 \mathrm{~cm}$. K. 150. Bez opr.

Historia ecclesiastica.

Inc.: k. 1: „Post annum a Christo nato 509 unde $\mathrm{X}$ de saeculo ecclesiae VIIlo comperta "habebam", k. 146.

Dalszy cıąg wykładów z historii Koścıoła obejmujący VI, VII i VIII w. Powstał w jednej z uczelni teologicznych wloskich. Papier wloskı. Reklamanty. Karty niezapısane: $116 \mathrm{v}-150$. Nielıczne poprawkı w tekście. Glosy marginalne bardzo rzadkie.

Składkı: 19. Ternion 12. Pozostałe kwaterniony. Kustosze literowe od Ccc-Xxx. Poza tym składkı numerowane w dolnym lewym rogu złożoną sygnatura.

Filıgrany: gołąbek w kole na potrójnym postumenciku z literą $F$ ponad kolem, k. 10, 15. Gołąbek $w$ kole na potrójnym postumenciku z literą $F$ ponad kołem, w kole inıcjały G S, k. 57, 64. W kole gołąbek na potrójnym postumenciku, pod kolem litera $F$, k. 91, 92.

Proweniencja: Biblioteka OO. Kapucynów w Krakowie. Sygn.: H 3.

103. Eac. II pot. XVII w. $20 \times 13.5 \mathrm{~cm}$. K. 128. Bez opr.

Historia ecclesiastica.

Inc.: k. 1: „Cum anno 195 Natalitio Domini die X ingenium et saeculi consuetudines videbatur exquirere. Finis", k. $128 \mathrm{v}$.

Wykłady $\mathrm{z}$ hıstorii Koścıła obejmujące IX, X i XI w. Pismo jednej ręki. Papıer z papıernı włoskiej. Karty nıezapisane: 7v, 8r. Glosy margınalne bardzo rzadkıe.

Składkı: 16 kwaternıonów. Kustosze literowe od Sss 3-Zzz 3, Aaaa-04.

Filıgrany: gołąbek $w$ kole na potrójnym postumenciku z literą $F$ ponad kołem, k. 1, 8. W owalu kotwica, poniżej owalu litera F, k. 33, 40. W owalu kotwica, powyżej owalu gwlazdka sześcioramienna, k. 66, 71. W tarczy herbowej $z$ koroną pięcıopałkową gołąbek na potrójnym postumenciku, z boku tarczy inıcjały D G, ponizej tarczy litera F, k. 80.

Proweniencja: Biblioteka OO. Kapucynow w Krakowie. Sygn.: H 1.

104. Eac. II pot. XVII w. $20 \times 13 \mathrm{~cm}$. K. 145. Bez opr.

Inc.: k. 1: ,Annus agebat R. S. 1099 fatoque cesserat $X$ ad praecipuorum saeculis XIII et XIV successionem", k. 142.

Wykłady z historii Kościoła obejmujące XII, XIII i XIV w. Papier z papiernı włoskiej. Reklamanty. Karty niezapısane: $142 \mathrm{v}-145$. W drugiej części ślady silnego zawilgocenıa od strony brzegu. Pierwsze 8 składek mniejsze od następnych.

Składkı: 17. Kwaterniony: 1-12, 14, 15, 17. Seksternion 16. Septentrion 13. Kustosze literowe P 4-Z 4, A 5-H 5. Poza tym składki oznaczone cyframı rzymskimi od I-XVII.

Filigrany: w owalu kotwica, ponad owalem gwiazdka sześcıoramienna, ponıżej owalu litera F, k. 1, 8. W owalu gołąbek na potrójnym postumenciku, ponad owalem litera F, k. 102, 103. W winjetce napıs: Fiorıny, k. 101, 104. W owalu gołąbek na potrójnym postumenciku, poniżej owalu litera $F$, ponad owalem korona (?), k. 139, 144.

Proweniencja: Biblioteka OO. Kapucynów w Krakowie. Sygn.: $\mathrm{H} 4 \mathrm{na} 1 \mathrm{k}$. , i $\mathrm{H}$ B na k. $154 \mathrm{v}$. 
105. Łac. II pot. XVII w. $20 \times 13.5 \mathrm{~cm}$. K. 180 . Bez opr.

Historia ecclesiastica.

Inc.: k. 1: „Diro schismatis tempore Bonifatius IX anno $1404 \mathrm{X}$ alter Principium Spirae coactus fuit an. $1529^{\prime \prime}, \mathrm{k}$. "177v.

Wykłady $\mathrm{z}$ historii Kościoła obejmujące wiek XV. Papier z papierni włoskiej. Reklamanty. Karty niezapisane: 178-180.

Składki: 21. Seksterniony 2, 11, 21. Pozostałe kwaterniony. Kustosze literowe I 5-Z 5, A 6-F 6. Poza tym wszystkıe składki posıadają na pierwszej karcie liczbę 15.

Filigrany: $w$ owalu gołąbek na potrójnej podstawce, obok inicjały G I, poniżej owalu litera F, k. 14, 15. Tarcza herbowa z koroną pięciopalkowa, $\mathrm{w}$ polu gołąbek na potrójnym postumenciku, k. 56, 57. Gołąbek w kole na potrójnym postumenciku i inicjałami $G \mathrm{~S}$, ponad kołem litera $F$, k. 122, 127 Goląbek w kole na potrójnym postumenciku, poniżej koła litera $F$, powyżej rodzaj winiety z inicjałami A M G, k. 171, 178.

Proweniencja: Biblioteka OO. Kapucynów $w$ Krakowie. Sygn.: H 2, k. 1.

106. Eac. 1790. $20 \times 13 \mathrm{~cm}$. K. 60. Bez opr.

„Epocha rerum gestarum in ditionibus et regnis Domui Austriacae subiectis disciplinam Ecclesiae Catholicae concernentium, sedente in $\mathrm{Ca}-$ thedra Petri Pio VI tenente clavum Imperii Romani Josepho II ab anno 1780 ad annum 1790 in Galicia".

Inc.: k. 1: „Ecclesia Catholica per totum orbem diffusa $X$ recepit $(F)$, Gallitam irrisit (g), Belgium amisit (h) ${ }^{\text {c }}$, k. 58.

Skrypt napisał o. Firminian Kuzel, Czech, kapucyn. Karty niezapisane: 58v, 59, 60. Poprawki w tekście. Rękopis zdefektowany, brak 8 i 9 składkı.

Składki: 6. Blok rękopisu wszyty $w$ obwolute $i$ jeden kwaternion zapisany tylko na k. 57, 58. Kwaterniony 2, 3, 4, 5. Kwinterniony $1,6$.

Filigrany: tarcza herbowa $\mathrm{z}$ koroną pięciopałkową i rogiem myśliwskim w polu tarczy, k. 60 Nazwa: Seneten Berg, k. 2, 59; J Honig, k. 55; Zoonen, k. 54.

Proweniencja: Biblioteka OO. Kapucynów w Krakowie. Pieczątka owalna na k. 1. Sygn.: Nr XC na k. 1.

\section{PRAWO KANONICZNE}

107. モac. 1735-1737. $19.5 \times 15 \mathrm{~cm}$. K. 284. Opr. sk. wsp.

1. k. $1-5 \mathrm{v}$. „Liber primus decretarium. De institutionibus et poenis eoclesiasticis earumque potestate... Anno Dni $1735^{\prime \prime}$.

Inc.: $\mathrm{k}$. 1: „Imus. Iuris varia est acceptio $\mathrm{X}$ impediat omnis consuetudo et praescriptio", k. $5 \mathrm{v}$.

2. k. 8-22. "Theologia moralis. De contractibus in genere et specie. Anno Domini 1735to in annum 1736tum. Ad dissolvendos ingeniorum et conscientiae nodos proposita Leopoli".

Inc.: k. 9: „Contractus definitive est pactum convenire $\mathrm{X}$ ex eodem textu damnant usuras", k. 22. 
3. k. 24-40. „Theologia polemica sive controversiae christianae de sanctissima Trinitate, processione Spiritus Sancti ac praedestinatione... Anno Dni 1735 in annum 1736 Leopoli".

Inc.: k. 25: „Ante resolutionem quaestionis praemitto non $\mathrm{X}$ quidquid de praedestinatione dictum est, cedat...", k. 40.

4. k. 44-59. ,Theollogia polemica seu controversio de Christo, de cultu et invocatione sanctorum, de cultu reliquiarum, imaginum ac de indulgentiis adversus moderni saeculi et anteactarum aetatum haereticos proposita... Anno Dni 1736 in annum 1737 in Scholis Leoburgicis Societatis Jesu".

Inc.: k. 44v: „1. Praemitto 1 mo quod articulum hunc $\mathrm{X}$ sic nobis gratiam largiat internis". k. 59.

5. k. 60-142v. "Tractatus theologicus de Deo nostro uno in essentia. trino in personis. Perfectissimo in utroque, eminentissime sciente et volente sanctissime a quaestione $1 \mathrm{ma}$ ad 43 tiam per disputationes scholasticas vere in enigmate viatoribus theologis utinam tandem in patria intuitive, et tanquam in speculo cognoscendo propositus in Scholis Collegij Leopolienisis Societatis Jesu. Ex anno 1735to in annum 1736 a die 2 da 7 bris".

Inc.: k. 61: „Lachrimas penitentiae nuper deplorando tempori $\mathrm{X}$ sine decreto Dei existere non posuunt", k. 142v.

6. k. 146-148. "Theologia scholastica de incarnatione Verbi divini in tertiam partem Divi Thomae ad mentem sanctae ecclesiae... In Scholis Collegii Leopoliensis Societatis Jesu. Anno Verbi incarnati 1736 in annum 1737 die 6 7bris".

Inc.: k. 146: „Illud fidei nostrae misterium hoc tractatu X cui omnia verba et apices nunc cedant", k. 284.

Profesorowie: o. Jan Gutkowski ${ }^{52}$ - prawo kanoniczne, o. Andrzej Łạczyński - teologia scholastyczna i o. Andrzej Siemıńskı T. J.

Reklamanty. Karty niezapisane: $6,7,8 \mathrm{v}, 22 \mathrm{v}, 23,24 \mathrm{v}, 34 \mathrm{v}, 41-43,59 \mathrm{v}$, $143-145,236-337$.

Składki: 34. Ternion 17. Kwinterniony 8, 10, 15. Seksterniony $4+1$ k., 24. Pozostałe kwaterniony ale $1,8134 \mathrm{bez} 1 \mathrm{k}$. Kustosze liczbowe.

Filigrany: myślıwy dmący w róg, k. 23. Matka Boska z Dzieciątkıem $\mathrm{w}$ otoku promieni, k. 237.

Oprawa w tekturę sklejaną, szmacıaną. Cała sk. cielęca barwiona na brązowo. Grzbiet zamalowany farbą szarą z napisem: „Scripta theologica Scholae S. J.“. Ramka na okładkach tłoczona grubą a cienką linią na clemno. Szycie na 3 sznurkı. Kapitałka szyta.

52 Ur. 3 IX 1696, do zak. wstąpił 1712, zm. 22 V 1765 w Kamıeńcu. - Necrol. Polonıae Minoris S. J. 1754-1770. ArSI, Pol. 89 f. 203; B a c ker-s om m ervogel III 1972-1973 (daty niepewne); Ks. J. Brown, Jw. s. 188; Enc. Chelm. XV/XVI 25; Estr. XVII 476; Ks. Sit. $\mathrm{Z}$ a 3 a $\mathrm{skl}$, JW. T. 2 s. 635. 
Proweniencja: 1. Biblioteka OO. Kapucynów w Olesku. Piecząlka okrągła na k. $1,112,238$.

2. Biblioteka OO. Kapucynów. Kraków. Pieczątka okrągła na wyklejce frontowej i k. $284 \mathrm{~V}$.

108. Eac., pol. I pot. XIX w. $38.5 \times 24.5 \mathrm{~cm}$. K. 222. Opr. płsk. usp. "Iu's canonicum accomodatum Ecclesiae Polonae".

Inc.: k. 1: „Nro 1mo. Coetus hominum ad certum finem colligatus $X$ castigationem clericorum corporalem in emendationem decretam ( $\$ 436$ et 501$)^{6}$, k. $221 \mathrm{v}$.

Reklamanty. Paginacja orygınalna: 140, 303. Blok rękopısu składa się z siwego papieru czerpanego. Kursywa duża l wyraźna.

Skladkı: 19. Kwinterniony 6, 7, 13. Pozostale seksterniony lecz 19 bez $1 \mathrm{k}$.

Filigrany: zdobnik w środku karty.

Oprawa w tekturę grubą, szarą. Grzbıet i rogi obciągnięte sk. cielęcą, z szyldzikıem naklejonym z cienkıej skórkı czerwonej, tłoczonym na ciemno z tytulem: "Ius canonicum". Grzbiet podzielony bordiurką tłoczona na ciemno, pola zdobıone tłokıem filıgranu takiegoż koloru. Obciągnıęcie okładek w papier klajstrowy barwiony ręcznıe na brązowo. Szycie na 3 sznurki. Zamıast górnej i dolnej kapitałkı - wzmocnıenie grzbietu wpuszczeniem 1 zaciągnięciem wałka. Brzegi czerwone.

Proweniencja: 1. „Obtulit Biblicthecae PP. Capucinorum Cracoviensium R. D. Matias Wójcikowski, capellae in arce Potociana capellanus d. 18 iulii 1850 anno". Napis na wyklejce frontowej.

2. Biblioteka OO. Kapucynów. Kraków. Pieczątka owalna na wyklejce frontowe], k. 70, 222v. Sygin.: $12 \Sigma_{1}-6$.

\section{FILOZOFIA SCHOLASTYCZNA}

109. Eac. $1670-1671.19 .5 \times 15 \mathrm{~cm}$. K. 489. Opr. perg. wsp.

„Cursus philosophicus biennalis in Alma Academia Crac[oviensi] per Clarissimum et Adm. Rndum Dominum D. Ioannem Michalski ${ }^{53}$ philosophiae doctorem collegam maiorem regium professorem ad ecclesiam sanctae Annae canonicum interea eiusdem cursus lectorem traditus anno Dni 1670 die maii““.

Inc:: k. 4: „Quia natura semper incipit ab universalioribus $X$ Soph. error per media apparentia“", k. 480.

Szkoła: Akademia Krakowska. Skryptor: ks. Kazımıerz Łubıeńskı, późnıjszy bp krakowski.

Reklamanty występu ą bardzo rzadko. Pagmacja orygınalna: nlb. 6, 938, nlb. 18. Karty niezapisane: 481-482, 486-489. Sp1s treścl na k. 483-485v. Składkl: 41. Ternion 40. Kwaterniony 5, 26, 32, 41. Kwinterniony 2, 4, 8,

53 Prof., rektor 1689-1690 I wicekanclerz Akad. Krak., zm. 7 IX 1655. I3ibi. Jag. zapisał 61 dzıeł. - Zbıór zwyczajnych modiltw s. 46; J. S. E a i d 1 ke : Historıa biblioteki UJ w Krakowie. Kraków 1821 s. 147: 'H. B a ry cz: Metryka promowanych Wydzlaku Teologicznego Uniwersytetu Krakowskiego z lat 1639-1741. Nasza I'rzeszt. T. 3 : 1947 s. 192-194; Enc. Orgelbr XVIII 462; Wielka encyklopedia powszechna ilustrowana. Ser1a 1. T. 1-48; Serı 2. T. 1-6 (do Otto Jan). Warszáwa 1390-1911 (skrót: Wielka enc. ilustr.). T. 45/46 S. 961; Estr. XXII 344-345; A. Ka r b owla k, JW. s. XLlX, Wl W 1słock1, JW; nr 199, $199,2564$. 
$10,12,14,16,20,22,24,28,30,34,36,38$. Okternion 37.21 ma $18 \mathrm{k}$. Pozostałe septentriony.

Filigrany: tarcza herbowa z korona, w środku orzeł dwugłowy, k. 2, 4, $482,487$.

Oprawa w tekture obciągnięta w całości w pergamın. Grzbiet malowany farbą olejną popıelatą $\mathrm{z}$ trzema kartuszamı ciemnozıelonymi, w górnym tytuł: „Cursus philosophicus in Alma Univ. Cracoviensi“, w środkowym sygn. literowa K (rubryk.), w dolnym miejsce na sygn. liczbową. Całość malowanego grzbietu znıszczona, wskutek odpadnıęcıa farby. Grzbiet wewnątrz wzmocniony makulaturą druku przebijającą przez wyklejkę. $\mathrm{Na}$ okładce frontowej 1 tylnej ramka dwulınıjna, w narożnikach od środka stempel filigranu z motywem kwiatów. Pośrodku frontowej okładkı sztanca z postacıą św. Jana Kantego klęczącego obok stołu przed otwartą ksıęgą. $\mathrm{Na}$ stole klepsydra. W dolnej czéści stołu napis: „Beatus Ioannes Cantıus Polonus S.T. D. in Acad. Crac. Prof. ab a. 1472“. Nad głowa świętego tarcza herbowa z berłamı uniwersyteckımı 1 korona. W otoku z prawej strony napıs: „Insygnıa Academiae Cracoviensis". Nad stolem wizja Matkı Bozej z Dziecıątkıem l św. Anny, którą okala wstęga z napısem: „S. Anna - Met Tertıa ora pro nobis". Ponadto przez nıą przewiązana druga wstęga opadająca z napısem: "Stude sapientıam Fili $\mathrm{ml}$ et laetifica cor meum. Prov. 27" (wiersz 11). Między postacıami wıyjnymi a herbem unoszący sıę anıł ze skrzydłamı, trzymający w lewej dloni wlanek róż a w prawej wieniec laurowy, którymi ma ukoronować głowę śwlętego. $\mathrm{Na}$ tylnej oprawie ramka, analogıczna jak na frontowej, a po środku drobny zdobnik $z$ rysunkiem serca promieniującego wokoło. W narożnikach odśrodkowych ramki filigranowe stemple z motywami kwıatów. Opisane wyżej tłoczenia były ongiś w całości złocone. Dziś pozostały $w$ wielu miejscach ślady złota o odcieniu miedzianym a na frontowe okładce środkowa sztanca błyszczy złotem. Kapitałka wyszywana jedwabiem zielonym i przewlekana, jak i rzemyki, poprzez okładkę $w$ zawiasach. Oprawa bardzo dobrze zachowana. Brzegi zlocone. W prawym rogu doInej okładki frontowej wyklejka była łatana a okładka od zewnątrz wskazuje na małe zaatakowanie przez kornik1.

Proweniencja: 1. Kazimierz Łubleński, bp krak.

2. „Ex libris a Celsissimio Principe Cas. Eubieński Ep. Cracov. donatis et applicatis Biblioth. Cracoviensi PP. Capucinorum". Napis na k. 2. Pieczattka okragla: Biblioteka OO. Kapucynów. Krałów, na k, 1v, 485v. Sygn.: 22 D-22; Nr XVII (o. Z. G.).

110. Eac. 1672. $19 \times 14.5 \mathrm{~cm}$. K. 518. Opr. perg. wsp.

1. k. 1-461v. „In philosiophiam naturalem secundam cursus philosophici partem".

Inc.: k. 1: „Hactenus in ediscendo ferendi modo X ultimam partem quam svavissime iniurio", k. 456.

2. k. $464-518 \mathrm{v}$. „In III cursus philosophici partem s. metaphisicam“.

Inc.: k. 464: „Ens qua ens sit obiectum $X$ grossum et palmam immarcescibilem largiatur", k. 517.

Szkoła: prawdopodobnie Akademia Krakowska. Skryptor: ks. Kazimierz Łubreńskı, późniejszy bp krakowskı. 
Reklamanty nielıczne. Oryginalna pagınacja: 103, nlb. 15; 104, nlb. 4. Karty niezapisane: 456v, 457, 462, 517v. Spis treścı na k. 458-460v i 461, 518. Inskrypcja na k. 517: "Corona felicis termini toto huic operi s[cilicet] tribus philosophrae partibus imposita. Anno 1672. Die 8 iunii".

Składki: 39. Binion 38, Terniony 16, 18, 20, 22, 24, 26, 28, 30, 39. Kwaternion 36 bez $2 \mathrm{k}$. Kwinterniony $1,3,6,8,10,12,14$. Seksterniony $5,33,34,35$. Septentriony 2, 4, 7, 9, 11, 32. Okterniony 13, 21. 15, 17, 23, $25,27,29,37$ po $19 \mathrm{k} ., 19,31$ po $20 \mathrm{k}$.

Filigrany: tarcza herbowa $\mathrm{z}$ koroną $\mathrm{i}$ orłem dwugłowym w pośrodku, k. 1, 139. W otoku dwa półksiężyce odwrócone, w środku miecz (podobne do herbu Ostoja), k. 518 i wyklejka tylna.

Oprawa w tekturę szarą, szmacıaną. Grzbiet i okladkı obciągnięte pergaminem. Grzbiet malowany farbą olejną popielatą $\mathbf{z}$ trzema kartuszami ciemno zielonymi: $w$ gómym tekst tytułu grzbietowego „Philosophia naturalis", w środkowym część sygn.: K (rubryk.), w dolnym miejsce na sygn. grzbietową. Szycie na 3 sznurki. Kapitałka wyszywana w dwóch kolorach. Brzegi silnie nakrapiane na czerwono.

Proweniencja: 1. Kazimierz Eubieński, bp kmak.

2. „Ex libris a Cels. Principe Cas. Eubieński Ep. Crac. domatis et applicatis Bibliathecae Crac. P. Capucinorum". Napis na k. 1. Biblioteka OO. Kapucynów. Kraków. Pieczątka okrągła na odwrocie wyiklejki frontowej i k. 518v. Sygn.: $22 \mathrm{D}-13 ; \mathrm{Nr} \mathrm{X}$ (a. Z. G.).

111. II pot. XVII w. $19 \times 15 \mathrm{~cm}$. K. 146. Opr. sk. wsp.

1. k. 1-135. "In decem Libros Ethicorum Aristotelis ad Nicomachum [commentarium]".

Inc.: k. 1: „Augustum felicis nomen beatamque naturam $\mathrm{X}$ precuum et voto devovemus. Dixi"“, k. 135.

2. k. 136-146v, "Tractatus de arte aemulae naturae".

Inc.: k. 136: „Nobilis genii et ingenii non plebeium argumentum $\mathrm{X}$ homagium et in demonstrationem pie venerationis argumentum", k. $146 \mathrm{v}$.

Szkoła: prawdopodobnie Akademia Krakowska. Skryptor: ks. Kazimierz Łubieńskı, późnıejszy bp krakowskı.

Reklamanty. Karty niezapısane: 135v. Bardzo skąpe glosy marginalne.

Składki: 12. Kwaternion 4. Kwinterniony 1, 6, 8, 10, 12. Seksternion 3. Septentriony 2, 5, 7, 9. 11 ma $20 \mathrm{k}$.

Filigrany: tarcza herbowa $\mathrm{z}$ koroną, w polu orzel polskı, wyklejka tylna. Orzeł dwugłowy $\mathrm{w}$ koronie $\mathrm{z}$ sercem $\mathrm{w}$ pośrodku, k. 1, 7, 116.

Oprawa w tekturkę obciągnıętą bialą sk. barwioną. Grzbıet malowany farbą zıeloną. W górnym kartuszu skrót tytułu wykonany czarną farbą, $\mathrm{w}$ środkowym znak sygnatury $\mathrm{K}$ w kolorze czerwonym, $\mathrm{w}$ dolnym wolne miejsce na sygn. liczbową. $\mathrm{Na}$ okładce frontowej ramkı w układzıe renesansowym z odciśnıętą na ciemno rolką renesansową z medalionami portrecików między stylizowanym ornamentem. Ramka wewnętrzna $z$ prostych linii, w narożnikach stemple z delikatnym rysunkiem kwiatowym. W pośrodku zwierciadła wianuszek owalny $\mathrm{z}$ listków. Na tylnej okładce, zwierciadło zatłoczone tym samym rysunkiem rolkı, jak $w$ ramce zewnętrznej. Szycie na 3 sznurki, których więzy wrdoczne na grzbiecie. Kapitałka wyszywana na plótnie. Brzegı nakrapiane na czerwono. 
Proweniencja: 1. Kazimierz Eubieńsiki, bp kraik.

2. „Ex Libris a Celsissimo Principe Cas. Eubieński Ep. Craco[viensi] donatis et applicatis Bibliothecae Cracov. PP. Capucinorum". Napis na k. 1. Biblioteka OO. Kapucynów. Kraków. Pieczątka okrągła na odwrocie wyklejki frontowej i k. 146. Sygn: $\mathrm{Nr}$ XLV (o. Z. G.).

112. $1686-1691.20 \times 16 \mathrm{~cm}$. K. 188. Opr. plperg. wsp.

1. k. 1-118v. ,Tractatus brevis de institutione logicae parvae. Sub Adm. Rdo in Christo Patre Fratre Hyacintho Lubowiedzki ${ }^{54}$ s. t. lectore pro tunc actuali in Conventu Luceoriensi philosophiae sapientissimo professore Ordinis Praedicatorum. Anno Dni 1686 die 5 mensis 9bris".

Inc.: k. 1v: „Nota: 1mo. Logica parva et dialectica, idem sonant $\mathrm{X}$ et sequentis anni laborem ex integro devoveo", k. $48 \mathrm{v}$.

2. k. 49-75v. "Liber binarius de ente mobili ad formam sive substantialem sive accidentalem scilicet de generatione et corruptione et rebus tribus quaestionibus comprehensus et per eas explicatus. Anno... millesimo sexcentesimo nonagesimo primo".

Inc.: $\mathrm{k} .49 \mathrm{v}$ : „Cum formae rerum sublunarium dependeant $\mathrm{X}$ et quid hominibus ferme tot annis", k. 75v.

3 k. 77-114. „Liber animasticus de ente mobili scilicet motu vitali ternarius quatuor quaestionibus comprehensus et per eas explicatus. Anno Dornini... millesimo sexcentesimo nonagesimo".

Inc.: k. 77v: "Cum motus vitalis sit omnium $X$ et tres libros de anima", k. 114.

4. k. 117-140v. „Metaphysica sive scientia transnaturalis disputationibus illustrata".

Inc.: k. 117: „Post considerationem rerum corporearum et sensibilium X non voluntate. Si quid indicat facere“, k. $140 \mathrm{v}$.

5. k. $141-188 \mathrm{v}$. „Liber metaphysicorum seu theologiae naturalis duodenarius quaestionibus comprehensus et per eas explicatus. Anno... millesimo sexcentesimo nonagesimo primo".

Inc.: k. 142: „Scias quod metaphysicam esse scientiam $\mathrm{X}$ quod non competit animae separatae", k. $168 \mathrm{v}$.

6. k. 169-188v. "Quaestio de Deo Praemotore".

Inc.: k. 169: „Scias. Quaestionem 6 de creatis quod in $\mathrm{X}$ et totus titulus articuli $2 \ldots . ., k$, $188 \mathrm{v}$.

Szkoła: studium filozofi domınikanów w Łucku. Lektorzy: o. Jacek Lubow1edzk1 ${ }^{54}$ w r. 1686 i o. Ludwik Krtowas w r. 1690 (k. 77v).

Reklamanty. Karty neezapisane: 76, 114v, 115, 116, 141v. Wklejki: 45, 161. Wyjątkowo zdarzają się glosy w jęz. polskim: k. 6: „Prawdę jeden powiedzıał, co z oczu, to z myśli"“; k. 10: „Jużem oznajmil dwa razy o sobre waszec1, a waszeć jakby mnie nıe znała. Bóg zaplać a za ten affekt, bom

54 Profesję zlozył w Przemyślu 1674, prot. fil. w Przemyślu 1683, przeor w Lublinıe 1727. - Informacji ud selił o. mgr Robert Swiętochowskı OP. 
lepszego nie godzıen“. Dalsze inskrypcje na k. 97, 109, 117. $\mathrm{Na} \mathrm{k.} \mathrm{118a}$ notka w jęz. starocerkıewnym. Wklejki $z$ napısami o treści filozoficznej na k. 112a, 113a, 118a.

Składkı: 25. Biniony 1, 11, 22+1 k., 24. Terniony 2, 7, 23. Kwaterniony $3,5,6$ bez $1 \mathrm{k} ., 8,9,10,12-16,19,20+1 \mathrm{k} ., 25$ bez $3 \mathrm{k}$. wydartych. Kwinternion $21+2 \mathrm{k}$. Seksterniony 4 bez $3 \mathrm{k} ., 17,18$.

Filigrany: orzel, k. 3, 4. Tarcza herbowa, k. 24, 25. Sowa, k. 45, 46. Głowa w koronıe, ponıżej półksiężyc, k. 116. Dwie postaci 1 napisy ponad i poniżej nich, k. 176, 177.

Oprawa w tekturę szarą. Grzbiet obciąnnięty pergaminem. Papier okładek czerpany, barwiony na wiśniowo, zupełnie wytarty. Rożki i boki okładek nadwerężone. Szycie na 2 sznurki, wzmocnione paskami płótna żaglowego. Brzeg1 czerwone.

Proweniencja: 1. „Michael Wiśniowskik ${ }^{\prime \prime}$. Napis na wyklejce frontowej.

2. Biblioteka OO. Kapucynów. Kraków. Sygn.: $22 \mathrm{D}-28$; Nr XII (o. Z. G.).

113. Eac. 1720. $19 \times 16 \mathrm{~cm}$. K. 227. Opr. płsk. wsp.

1. k. $1-73$ v. „Corona assidul sedulique laboris praemium gemmeis sanguinei sudoris guttis rutilans. Pretiosis Aristotelis textuum gemmis seu quibusdam lectionibus per textus dispositis sci[licet] philosophia B. M. Alberti libris de anima computii sphaera et quaestionibus de conatibus refulgens. Simul tandem eruditis clarissimorum doctorum et professorum conatibus adornata. Per me vero Ioannem Cantium Gasparum Sokołowski ${ }^{55}$ earumdem lectionum auditore propria opera et manu exposita. Anno Domini 1720 die 21 aprilis".

Inc.: k. 2: „Philosophiam caelitus ab ipso Deo concessam $\mathrm{X}$ auditoris perfectum et incrementum dicta sunto", k. 73v.

2. k. 74-122. „Hic eximius beati Magni Alberti tractatus in Alma Universitate Cracoviensi professoris dignissimi sapientissimique finitus est cum Dei nomine a M. Hieronimo Tortowski in eadem Universitate philosophiae doctore et professore nobilissimo. Scriptus vero a generoso Domino Joanne Cantio Gaspare Sokolowski eiusdem tractatus auditore. Anno Domini 1720 die 12 septembris".

Inc.: k. $75 \mathrm{v}$ : „Circa hoc quaesitum duae sunt opiniones $\mathrm{X}$ non sensit calidam aeque calidas", k. 122.

3. k. 123-160v. ,In computus ecclesiastici seu calendarii gregoriani explanationem praefatio".

Inc.: k. 123: „Duplex est inscriptio praesentis tractatus $\mathrm{X}$ auditori vero nobilissimo in emolumentum cedat", k. 160v.

4. k. 161-206v. "In sphaeram Joannis de Sacro Bosco praefatio".

Inc.: k. 161: "Quaeritur ad 1mum inscribitum hoc opus X considerationem grato suscipe animo precor", k. 206.

5 Por. Estr. XXIX 7. 
5. k. 207-227v. „Sancte Joannes Canti, adsis mihi inhoanti exercitia seu quaestiones in Quatuor Libros Aristotelis priores".

Inc: k. 207: "Occasio dubitandi sumitur ex philosopho, qui una ex parte $X$ totıus universi apparebit ruinam compositi", k. 227.

Treść: objaśnienie pısm Arystotelesa na podstawie doktryny filozoficznej Alberta Wielkiego.

Szkoła: Akademı Krakowska. Profesorowie Fieronim Tortowski ${ }^{\text {s6 }}$ i Józef Rembeck1 ${ }^{57}$.

Reklamanty. Karty niezapisane: 1v, 122v, 157v, 158v. Wklejkı na k. $128 \mathrm{v}, 149 . \mathrm{W} 1 \mathrm{cz}$. początkowe rozdziały rubrykowane. $\mathrm{W} 3 \mathrm{cz}$. liczne rysunk1.

Składki 22. Binion 16 bez $2 \mathrm{k}$. wyclętych. Kwaterniony 2-4. Kwinterniony $7,8,15$, 18. Septentriony 5. Pozostałe sekstentriony lecz 5 bez $2 \mathrm{k}$, 12 bez 1 k., $13+1$ k., 19 bez 1 k. wyclętej i 22 bez 3 k. wyclętych. Kustosze literowe od $\mathrm{A}-\mathrm{X}$.

Filigrany: tarcza herbowa $\mathrm{z}$ korona pięciopałkowa, w połowie tarczy półorzeł, k. 4, 7, 226. Inicjały M I, k. 6.

Oprawa w tekturę szarą, półmiękką. Grzbıet i rożki obciągnięte sk. cielęcą barwıoną na brązowo. Okładki obciągnıęte papierem czerpanym barwıonym na czerwono. Na grzblecie ślady linii tloczonych $\mathrm{w}$ poprzek na cıemno a na okładkach dwie ramkı: jedna zewnętrzna, druga wewnętrzna, wyciągnięte lını́mi grubymi na ciemno. Szycie na 2 rzemykı. Kapitalka ręcznie szyta. Brzegi nakrapiane na czerwono 1 niebiesko.

Proweniencja: 1. Jan Kasper Sokołowski.

2. Bibliotelka OO. Kapucynów. Kraków. Pieczątka olsrągła na k. 1v, 227v. Sygn.: $22 \mathrm{E}-3$; Nr XV (o. Z. G.).

114. Łac. 1720-1721. $20 \times 15.5 \mathrm{~cm}$. K. 446. Opr. ptsk. wsp.

1. k. 1-57. ,Philosophia peripatetica in ipsis principiis Aristotelicis vasta. Recentiorum sententiis vastior. Materia et obiecti amplitudine vastissima. A primo apice ad auge[ndum] usque cursu suo provecta. Ab anno... 1720 in annum $1721^{\prime \prime}$.

Inc.: k. 3: „Philosophiae in voce sapientiae amor $\mathrm{X}$ finem modumque in fallaciis imponimus", k. $57 \mathrm{v}$.

2. k. 58-406. „Logica maior scholasticis disputationibus explanata... Anno 1720 Lublini".

Inc.: k. 61: „Ad noscendam naturam logicae (sicut et cuiusvis scientiae) $\mathrm{X}$ formidine radicali obiectiva et simul scientia", k. $405 \mathrm{v}$.

3. k. 407-432v. "Mathesis in Academo Lublinensi demonstrationibus illustrata anno... 1720 in annum 1721".

Inc.: k. 408: "Mathematicam multis commendare elogiis supervacaneum $\mathrm{X}$ dimensionem in longum, latum et profundum", k. 432.

4. k. 433-446. „Gnomica seu horographica scientia in Academo Lublinensi demonstrationibus illustrata. Anno... 1721".

55 Prawoiopodobnie nie chodzi tu o Hieronima a o Jana Chryzostoma Tortowskiego. Por. E s t r. XXXT 230-231.

${ }^{57}$ Prace jego podaje Estr. XXVI 237-239. 
Inc.: k. 433v: ,Siquidem inter innumeras mathesis nostrae $\mathrm{X}$ B. ad austrum, D. ad orientem, C. ad occidentem", k. 466.

Szkoła: Kolegıum jezuitów w Lublinie. Profesorowie: o. Franciszek Simonett ${ }^{58}$ (logika), o. Ksawery Brzeski ${ }^{5 y}$ (matematyka 1 etyka) i 0 . Andrzej Kuzersk ${ }^{60}$ (metafizyka).

Rękopis wykonany prawdopodobnie dwiema rękami. Czolowy tytuł w winietce szarozielonej. Rubrykowane tytuły: k. 1, 2, 157v, 407, 409v, 446v. wyklejka tylna. Rysunki i wykresy cz. 4 na k. 435v, 436v, 437, 438v, 440, $443 \mathrm{v}, 445 \mathrm{v}, 446 \mathrm{v}$. Ozdobne wykresy twierdzeń filozoficznych na k. $31,33 \mathrm{v}$, 34. Rysunki 1 wykresy wykonane w kilku kolorach. „Arbor porphyriana" na k. 12.

Skladki: 41. Biniony 36,37 bez 1 k., 41. Ternion 26. Kwaterniony 5, 22, 29, 31, 33, 35. Kwinterniony 2, 4, 6, 11, 13, 15, 17. Seksterniony 9, 10, 16, $19,20,21,23,24,25,27$. Septentriony $3,7,8,12,14,18,28$. Okterniony $1,30,32,34,38-40$.

Filıgrany: tarcza herbowa $\mathrm{z}$ koroną, k. 28, 31.

Oprawa płsk. $\mathrm{w}$ tekture sklejaną $\mathrm{z}$ makulatury polskiej. $\mathrm{Na}$ grzbıcie wmalowane dwa pola. Okładka obciaggnięta papıerem czerpanym $\mathrm{z}$ ornamentem wytlaczanym na tle zielonym. Szycie na 3 sznurki. Kapitałka ręcznie szyta. Brzegi nakrapiane na czerwono.

Proweniencja: 1. „Scripta culusdam Celsissimi accomodati Bibliothecae Olescensi PP. Capucinorum". Napis na k. 1.

2. Biblioteka OO. Kapucynów w Olesku. Pieczątka okrągła na k. 1, 188, 358. Dawniejsza sygn.: 176. Nowsza: VI 24.

3. Biblioteka OO. Kapucynów. Kraków. Pieczątka okrągła na odwrocie k. tytułowej i tylnej wyklejce.

115. Łac. $1729.19 .5 \times 15.5 \mathrm{~cm} . K$. 154. Opr. ptsk. wsp.

1. k. $1-31 \mathrm{v}$. „Dialectica seu introductio ad universam philosophiam immo et alias scientias".

Inc.: k. 1: „Dialectica communiter dicitur scientia quaedam et compendium logicae $\mathrm{X}$ plura usus et frequens exercitium disputandi docebit", k. $31 \mathrm{v}$.

2. k. 32-154v. „Philosophia rationalis seu logica disputationibus scholasticis illustrata... In Collegio Leopoliensii Societatis Jesu. Anno $1729^{\prime \prime}$.

Inc.: k. 32v: „Logica ex graeco ad vocem idem est $\mathrm{X}$ ad finem nostrum ultimum referamus sitque ultima conclusio", k. 154v.

Szkoła: Kolegium jezuitów we Lwowie. Profesorowie: o. Chryzostom

58 Ur. 16 VIII 1689, do zak. wstapil 1704. W czasse kasaty zakonu przebywał w kolegium gdańskım. - Cat. I Coll. Sandomiriensıs S. J. a. 1743; Al'SI, Pol. 27 f. 256 nr 6; Ks. St. Z aŁę s k l, Jw. T. 3 s. 1287 .

59 Ur. około 1683, do zak. Wsíąpił 1700, zm. 9 I 1723 w Przemyślu. - Dispositio personarum Provinciae Polonae S. J, a $I$ IX 1701 in a. 1702; ArsI, Pol. 45 (Domus probationis Cracoviensis); Cat. pers. et offic. Prov. Polonae S. J. pro a. 1724. Defuncti a. 1723; ArsI Pol. 46; B a cker-Sommervoge I vir 1219; Bp W W ó c 1 k, jw. s. 305 nr 149, 150.

to Ur. ok. 1683, do zak. wstąpił 1700, zm. 14 vIII 1741 w Jarosławiu. - Catalogi breves Prov. Poloniae S. J. 1700-1742; ArSI, Pol. 45-46. 
Sawicki ${ }^{\text {"1 }}$, wykładający logikę; o. Hieronim Grappini ${ }^{82}$, wykładowca fizyki 1 metafizyki.

Karta tytułowa wyrwana. Rysunek ,arbor porphyriana“ na k. 7v. Wykresy twierdzeń filozoficznych na k. $18 \mathrm{v}-19 \mathrm{v}$.

Składki: 17. Biniony $3+1$ k., 4, 6. Terniony 1, 13, 15, 17. Kwaterniony 5, 14. Kwinternion 12. Seksterniony $7,8+1 \mathrm{k} ., 9$ bez $1 \mathrm{k} ., 11,16$. Septentrion 10. Okternion 2.

Filigrany: na tylnej wyklejce inicjały BZO.

Oprawa półmıękka w sk. baranią ściemnioną na brązowo. Grzbiet zamalowany farba na popielato. Papier czerpany kolorowany na wiśniowo. Szycie na 3 sznurki. Brzegi nakrapiane.

Proweniencja: 1. Biblioteka OO. Kapucynów w Olesku. Pieczątka okrągła na k. 1, 68, 115. Sygn.: VI 23.

2. Biblioteka OO. Kapucynów. Kraków. Pieczątka okrągła na wyklejce frontowej i k. $154 \mathrm{v}$.

116. Pol. 1730. $18 \times 13.5 \mathrm{~cm}$. K. 44. Opr. ptsk. wsp.

„Filozofia moralna do politycznego i chrześciańskiego życia należąca. Prizez publiczne lekcije podana i explikowana w Karola Ferdinanda Akademii Pragskiej. Przez X. Jana Senftleben ${ }^{62 a}$ Soc. Iesu. Teraz zaś na polskit język przez jednego kawalera polskiego wytłumaczona. Tamże w Pradze R. P. 1730".

Inc.: k. 2: „Koniec fillozofii moralnej jest szczęśliwość najwyższa X przyjacielskie złączenie, ale niecha'j się razem nie przerywa“, k. 43.

Paginacja oryginalna: nlb. 2, 84, nlb. 4. Karty niezapisane: 1v. Na końcu spis rzeczy sporządzony inną ręka z podpisem: „1785 die 20 febr. scripsi“". Każda strona znaczona w górnym marginesıe małym krzyżykiem. $\mathrm{Na}$ wyklejce tylnej okładki inskrypcja: "Caro hilarıs recedat 1eiunio, sacrata tempora veniunt salve".

Składki: 6, Binion 6. Pozostałe kwaterniony.

Filigrany: tarcza herbowa z orłem, na wyklejce tylnej. Postać mężczyzny z kielichem i kobiety z kwiatamı w prawej ręce, k. 13, 14.

Oprawa w tekturę. Grzbiet i rożki sk. barwiona. Okładki obciągnięte papierem klajstrowym, barwıonym. Szycie na 2 tasiemki. Brzegi nakrapıane na niebiesko.

Prorweniencja: 1. „Tę książke przyslał mi J. W. J. M. Pan Starosta Żarnowiecki i jego samego jest fatyga $w$ przetlumaczeniu $i$ pisania jej“. Napis na k. 1.

2. „Ex libris A. Jurkowski". Napis na k. 44v.

3. Biblioteka OO. Kapucynów w Krakowie. Pieczątka owalna na wyklejce trontowrej, k. 14, 44. Sygn.: K 236; $22 \mathrm{D}-5$ (o. Z. G.).

61 Ur. 1693, do zak. wstąpił 1710, zm. 3 IV $1747 \mathrm{w}$ Brześclu nad Bugiem. - Cat. I. Coll. Brestensis S. J. 1743; ArST, Pol. 27 f. $14 \mathrm{nr}$ 6; Cat. pers, et offic. Prov. Polonae S. J. ex a. 1747 in a. 1748; ArSI, Pol. 48 (Defuncti).

62 Ur: 1692, do zak. wstąpił 1707, zm. 15 IV $1748 \mathrm{w}$ Torunıu. - Cat. I Coll. Calissiensis S. J. a. 1743; ArsI, Pol. 27 f. $20 \mathrm{nr}$ 7; Cat. pers. et offic. Prov. Polonae S. J. ex a. 1749. ArSI, Pol. 46 (Defuncti).

62a Ur. 12 IX 1648 w Glogowı, do zak. wstąpił 1665, zm. 3 XI 1693 w Kłodzku. - B a c k e rS o m m ervog el VII 1122-1123. Rękopis jest prawdopodobnie skrótem pracy pt. Converśatio politico-christiana ad leges ethicae politico-morales in Universitate Carolo-Ferdinandea Pragens1 public1s praelectionibus explicata per P. Joannem Senftleben S. J. Pragae 1681. Typis Univ, Car. Ferd. in Coll. S. J. ad S. Clementem $12^{3}$ Ss. 133. Ed. 21683. 
117. Eac. 1744 -1745. $22.5 \times 18 \mathrm{~cm} . K .163$. Opr. ptsk. wsp.

,Scientia natural is universam huius mundi machinam suis reprae-sentans titulis pro maiori discentium commodo scholasticis disputationibus illustrata in Collegio Vołuciano. Anno Domini 1744to die 9na maii".

Inc.: k. 2: „Nomen ipsum principii tali formae $\mathrm{X}$ quae totius vitae actus dirigat", k. 163v.

Szkoła: Kolegium jezuitów w Łucku. Profesor: o. Jan Karpowsk1 $1^{6: 3}$

Reklamanty. Na marginesach numery paragrafów. Podkreślenia w tekście. Kolofon na k. 163v: ,Finıvımus die 5 aprilis 1745 anno sub Adm. R. P. Karpowski S. J. professore dignissimo".

Składkı: 20. Terniony 4, 10. Seksterniony 8, 13. Pozostałe kwaterniony lecz 20 bez $1 \mathrm{k}$. Kustosze literowe od A-V.

Filigrany: tarcza herbowa $\mathrm{z}$ koroną pięc1opalkową, k. 1, 4.

Oprawa półmiękka w tekturę szarą, szmacıaną. Grzbiet sk. baranıa kolorowana na brązowo. Okładka obclągnıęta papıerem czerpanym marmurkowym wykonanym na karagenie. Szycie na 3 paski pergaminowe. Brzeg1 nakrapiane na niebiesko.

Proweniencja: 1. Biblioteka OO. Kapucynów w Olesku. Pieczątka okrągła na k. 1, 144. Sygn.: K 119; VI 17.

2. Bibliotelsa OO. Kapucynów. Kraków. Pieczątka okrągła na k. 1v, 163v.

118. Eac. 1746-1748. $20 \times 16 \mathrm{~cm} . K$. 294. Opr. ptsk. wsp.

1. k. 1-38. „Philosophia peripatetica ad veram Aristotelis mentem digesta et disputata... In Collegio Stanislaopoliensi S. Jesu anno... 1746 in annum 1747 die 2 7bris. Josephi Jakubow'ski".

Inc.: k. 1v: Philosophia, quam explanare agredimur, non est illa $\mathrm{X}$ tum de illis de quibus procedunt praecepta“, k. $35 \mathrm{v}$.

2. k. 39-142. „Pars prima philosophiae peripateticae id est rationalis scientia logica ad veram Aristotelis mentem digesta et disputata... In Collegio Stanislabopoliensi Socie[tatis] Jesu anno 1746to in annum 1747 mum ex integro dedicata. Josefi Jakubowski“".

Inc.: k. 39v: "Logicam quam agredimur in quatuor controversiones $\mathrm{X}$ in praemissas singulares conclusionem...", k. 139v.

3. k. 143-238. „Pars siecunda philosophiae peripateticae id est scientia naturalis phisica ad veram Aristotelis mentem digesta ac disputata... In Coll. Stanislaopoliensi S. J. 1747 anno 19 mail ex integro dedicata. J. J. sub R. P. B.“

Inc.: k. $143 \mathrm{v}$ : ,1. 1 mum principium dupliciter accipi potest $\mathrm{X}$ vacua non fuit, non ficte imitemur", k. 238.

4. k. 239-260v. ,Pars tertia philosophiae peripateticae id est ultra

${ }_{63}$ Ur. 24 VI 1708, do zak. Wstąpił 1726. W czasie kasaty zakonu nalezał do kolegium w Ostrogu. - Cat. I Coll. Cremenecensis S. J a. 1770; ArSI, Pol. 42 f. 26 nr 13; Cat. pers. et offic. Prov. Poloniae Minoris S. J. ex a. 1772 in a, 1773. Premisliae 1773 s. 19; Ks. St. Z al e s k l, Jw. T. \& s. 1548, 1550. 
naturalis scientia metaphisica ad veram Aristotelis mentem digesta ac disputata... In Collegio Stanislaopoliensi S. Jesu die 5 februariti dedicata“.

Inc.: k. 239v: „Metaphisica ex mente Arristotelis est scientia X quae tradidi de ente denominatione consecrato voto enti entium Dei nostri gloriosissimi", k. 260v.

5. k. 261-284. „Pars 4ta philosophiae 2dae physicae animastica in duas controversias digesta. Unam quae a centro terrae usque ad supremam superficiem mundi machinam transcendit et contemplatur alteram quae philosophum inter aspiciendi gratias introducit... In Collegio Stanislaopoliensi Soc. Jesu anno Dini $1748^{\prime \prime}$.

Inc.: k. 262: Nomine sistematis mundi intelligitur certa $\mathrm{X}$ illam vel praesentem vel praeteritam vel irrevocabilem. Et iam hic..., k. 294.

Szkoła: Kolegium jezuitów w Stanisławowie. Prof. o. Kasper Balsam ${ }^{0 !}$, wykładający logikę, fizykę 1 metafizykę. Skryptor Józef Jakubowskı.

Reklamanty. Karty niezapisane: 16, 36, 142v, 284. Rysunki: ,arbor porphyrıana" na $k$. 7v, ,schema propositionum" na $k$. 25-26v, budowa wszechświata na k. 261v, 262-263, 264. Inne wykresy na k. 275-280.

Składki: 71 binionów.

Filıgrany: ornament roślinny, k. 142. Matka Boska z Dzieciątkiem w otoku promienı, k. 140, 141.

Oprawa w tekture sklejaną. Płsk. bydlęcy barwıony na ciemno. Okładka obciągnięta papıerem czerpanym, grzebienıowym na karagenıe. Szycie na 3 sznurkı. Brzegi nakrapiane.

Proweniencja: 1. „Josephi Jalkubow'ski“. Napis na k. 1.

2. „Patrum Capucinorum Conventuis Mariampolensis 1766. Post fata J. R. D. Josephi Jakubowski vicedecani Collegiatae Stanislaopoliensis 1766". Napis wpleciony na karcie tytuinowe

3. Biblioteka OO. Kapucynów w Olesku. Pieczątka olkraggła na k. 1, 129, 208. Sygn.: VII 21.

4. Bibliołeka OO. Kapucynów. Kraków. Pieczątka okrągła na wyklejce frontowej i k. 284v.

119. Łac. 1746-1748. $22 \times 17.5 \mathrm{~cm}, K, 190$. Opr. brosz. wsp.

„Philosophia iuxta Ar[istotelis] principia et recentiorum experimenta... in Alma Wirceburgensium Universitate cursu triennali tradita et explicata annis... [1]746, 47 et 48 ab Admodum R. P. Petro Eisentraut S. J. a. a. 1. 1. et philosophiae magistro eiusdemque in Alma Wirceburgensium Untiversitate professiore publico et ondinario anno 1746 conscripta vero a me Joanne Tobia Hörlein S. J. logico".

Inc.: k. 3: „Philosophia, si etymologiam nominis spectemus $\mathrm{X}$ incurabilis est, cum medicum non curetis", k. $190 \mathrm{v}$.

Szkoła: Uniwersytet w Würzburgu. Profesor: o. Piotr Eisentraut ${ }^{\text {os }}$ T. J.

${ }_{64}$ Ur. 5 I 1715 (innı: 26 XII 1713), do zak. wstapil 1731, zm. 8 XII $1760 \mathrm{w}$ Krakowie. Jeden z wybitnych kaznodzıejów XVIII w. - B a ck e r-S o m e rvoge 1 I 851-952; Ks. J. B r o w n, Jw. s. 108-109; Enc. Chelm. III/IV 83; Enc. Orgelbr. II 760; Es tr. XII 347-348; J o c her nr 3785, 4531, 4532, 5143;-Pol. Stown. biogr. I 342-343 (St. Bednarski).

6s Prof. filozofii na Uniwersytecıe $w$ Würzbusgu. Ur. 29 VIII 1711 w Sessbach (Bawaria), do zak. wstąpił 1731. - B a cker-Sommervoge 1 III 327. 
Skryptor: Jan Tobiasz Hörlein ${ }^{06}$, późniejszy o. Felicissym z Würzburga, kapucyn.

Karty nıezapısane: 1, 2v, 81r, 167. Tytuł kodeksu oraz nagłówki rozdzıalów wykonane ręcznle $w$ formie liter drukowanych. Inskrypcje: $k$. 80v: "Nomina Dominorum logicorum sub Reverendo Patre Eisentraut 1745-1746"; jak wynika z wykazu nıektórzy słuchacze wstąpili do różnych zakonów $\mathrm{m}$. i „Böchner. Repetens. Factus est capucinus in Provincia Rhenana“; k. 166v: „Finıs 4 iulii 1747“; k. 169: „Florileg1um dubiorum ab Admodum Reverendo ac per quam erudito Domino Nicolao Kahles pro tempore nobilium in Seminarı .S. Kilianı Wirceburgi repetitore dictatorum conscriptorum a me Joanne Tobıa Rocho Hörlein...".

Składki: 24 kwaterniony. 21 bez $2 \mathrm{k}$. wydartych i 24 bez $1 \mathrm{k}$. wydartej Kustosze literowe od $\mathrm{A}-10 \mathrm{~K}$, dalszych brak.

Filigrany: tarcza herbowa z korona pięciopalkową, k. 1, 2. Postać ludzka, k. 167. Zdobrik, k. 79. Orzel dwugłowy $z$ koroną, $z$ boku inicjały W $B$. wyklejka tylna.

Oprawa w tekturkę szarą. grzbiet i okładkı obciaggnięte w całości papierem klajstrowym barwionym na brązowo (Pappband). Grzbiet uszkodzony. Szycie na 2 sznurki. Brzegi nakrapiane na czerwono.

Proweniencja: 1. Jan Tobiasz Hörlein.

2. Biblioteka OO. Kapucynów. Kraków. Pieczątika okrągła na k. 1v, 2v, 190v. Sygn.: $22 \mathrm{~F}-6$; $\mathrm{Nr} \mathrm{XIV}$ (o. Z. G.).

120. Eac. I pot. XVIII w. $24 \times 18.5 \mathrm{~cm}$. K. 137. Opr. brosz. wsp.

Philosophia scotistica.

Inc.: $1:$, Traotatum hoc variis titulis authores insigniunt $\mathrm{X}$ aliqua verba ad reprobandum. Negat Pont.", k. 136v.

Podręcznik filozoficzny w duchu Duns Scota, używany w studium domesticum $w$ jednym z klasztorów kapucyńskıch przed r. 1750. Swiadczy o tym m. in. Inwokacja do św. Franiciszka we wstępie do logiki. Karty niezapisane: $27 \mathrm{v}, 88 \mathrm{v}$ (na jednej przygotowane miejsce dla, ,arbor porphyriana" ale z niewiadomych powodów rysunek nie został wykonany). Wstawka, k. 137. Numery paragrafów na margınesach. Nieliczne giosy margınalne. Rysunkı: 15v, 16, 24v.

Składki: 19. Binion 4. Terniony 1, 11 bez $3 \mathrm{k}$. Kwinternion 9. Pozostałe kwaterniony. Kustosze liczbowe od 5-18.

Filıgrany: korona pıęciopałkowa, pod nią duże inicjały I F, k. 23.

Oprawa w tekture sklejaną $z$ makulatury $z$ drukiem o tekście niemieckim. Grzbiet 1 okładki obciągnięte czerwonym papierem czerpanym obecnie silnıc spłowriałym. W rogu dolnym okładki tylnej spod tegoż papieru wygląda papier klajstrowy brązowy; z tego wynika, że oprawa pierwotnie była pokryta tym papjerem a dopiero po jego zniszczeniu - powtórnie czerwonym papierem czerpanym. Szycle na 3 sznurki. Slad rzemyka do wiązania.

Proweniencja: Biblioteka OO. Kapucynów. Kraków. Sygn.: $22 \mathrm{~F}-36 ; \mathrm{Nr} \mathrm{V}$ (0. Z. G.).

121. Eac. 1752-1753. $19.5 \times 15.5 \mathrm{~cm} . K$. 282. Opr. ptsk. wsp.

1. k. 1-141. „Ad... iuventutis eruditionem philosophia. Pro rerum

68 Ur. 16 VIII 1726, do zak. Wstąpik 1749, zm, 16 IV 1772 w Lublinie. - CPP nr 132; Mortuologium, jw. 
tractandarum praestantia studiosis pro laboris difficultate advocatis singularibus et toto Authori universorum dedicata... In Collegio Stanislao[poliensi] Societatis Jesu. Annю Dni 1752 in annum 1753. Joannes Terlecki mpp."

Inc.: k. 2v: ,Si teste ortodoxae ecclesiae ac divino doctore $\mathrm{X}$ ad eundem intellectum et omnia referamuls...", k. 141.

2. k. 143-221v. ,Physica generalis menti Aristotelis conformis universarum rerum corporearum naturam suis disputationibus complectens. Illo studio insignis cui totam nostram retulimus philosophiam".

Inc.: k. 143v: „Disputatio haec erit de principiis intrinsecis $\mathrm{X}$ qui est Alpha et Omega Deus cui omnia...", k. 221v.

3. k. 223-282v. „Physica particularis menti Aristotelis conformis principalis divinae omnipotentiae opera complexa. Illo studio insignis cui totam nostram retulimus philosophilam".

Inc.: k. 223: „Principium operum omnium a caelo $\mathrm{X}$ a quo nostri labores sicut et finis idem...", k. 282v.

Szkoła: Kolegium jezuitów w Stanisławowie. Profesor: o. Ignacy Bełżecki ${ }^{67}$. Skryptor: Jan Terlecki ${ }^{\text {} 9}$.

Reklamanty. Karty niezapisane: 2r, 141v, 142, 222. Na marginesach numery paragrafów. Glosy marginalne.

Składki: $31.1 \mathrm{ma} 38 \mathrm{k}$. Binion 31. Terniony 4, 22. Sekstemion 21. Pozostale kwaternony ale $2+1 \mathrm{k}$., 13 bez $2 \mathrm{k}$. Kustosze liczbowe: 1-13, $1-9,1-7$.

Filıgranów nie ma

Oprawa w makulaturę rękopıśmienną polską. Grzbiet obcıągnięty sk. brązową. Okładki obciągnięte papierem czerpanym barwionym klajstrowo na kolor zielony. Szycie na 3 więzy.

Proweniencja: 1. „Joannes Terlecki“. Napis na k. 1. „Haec philosophia accepta est a Domino Terlecki meo condiscipulo quondam in saeculo". Napis na frontowej wyklejce.

2. Biblioteka OO. Kapucynów. Kraków. Pieczątka okragła na odwrocie frontowrej wyklejki i na wyklejce tylnej. Sygn!: $22 \mathrm{D}-32$; Ir VI (o.Z. G.).

122. Eac. $1759-1760.18 .5 \times 11 \mathrm{~cm} . K .110$. Bez opr.

1. k. 1-101v. „Dissertationes pnysicae ad methodum scholasticam accomodatae et auditoribus suis propositae in Universitate Leopolitana anno ischolastico eo quo eiusdem Universitas publica totius Provinciae Russiae nec non cum plenissimae urbis huius emolumento aptae sc[ilicet] 1760 ex 1759 mense aprili".

Inc.: $\mathrm{k} .1 \mathrm{v}$ : ,Non est eiusmodi scientia physica quam commendare $\mathrm{X}$ more institutorum maiorum nec aliter facere volui quam gubernii“", k. $101 \mathrm{v}$.

67 Ur, 1 VIII 1724, do zak. Wstąpil 1739, zm, $10 \mathrm{~V} 1756 \mathrm{w}$ Lublinie. - Cat. I Coll, Ostrogiensis S. J. a. 1743; ArSI, Pol. 27 f. $180 \mathrm{nr} 40$; Necrol. Prov Poloniae Minoris S. J. 1754-1770; ArSI, Pol. 89 f. 34 .

8s E s tr. XXXI 110 (?). 
2. k. 103-110v. ,Philosophia moralis praecepta et dogmata ad vitam recte et beate instituendam praescribens seu ethica et ius naturae auditoribus philosophiae explanata in Universitate Academica S. J. Anno 3760 die 26 8bris".

Inc.: k. 104: „Ethica est illa pars philosophiae quae mores X Platonici ferre sciunt succumbere nesciunt", k. 110.

Szkoła: Uniwersytet jezuitów we Lwowie. Profesorzy: o. Konstanty Awedyk ${ }^{69}$, wykładowca etykı; o. Dominik Sędzımır ${ }^{70}$ wykładowca fizykı i metafizyki.

Karty niezapısane: 64-68, 102, 103v Na margınesach numery paragrafów. Glosy na k. 51, która przez zawinięcıe do środka, nie została obcıęta przez introligatora.

Składkı: 15. 14 ma 2 k. Terniony 4, 9. Pozostałe kwaternıony.

Filigrany: Fragment fil. w lewym gónnym rogu karty

Blok kajetu ongı́ oprawnego. Okładek 1 grzbietu brak. Szycie na 2 paskı pergaminowe. Brzegi czerwone.

Proweniencja. 1. „Ex Bibl. PP. Capuc[inorum] Mariampol[iensium]“. Napis na k. tytułowej.

2. Biblioteka OO. Kapucynów w Olesku. Pieczątka okrągła na k. 1.

3. Biblioteka OO. Kapucynów. Krakków. Pieczątka okrą̧gła na k. 1.

123. Eac. 1760-1761. $23 \times 19 \mathrm{~cm} . K$. 117. Opr. ptsk. wsp.

1. k. 1-105v. „Philosophiae aristotelico-scotisticae pars II videlicet physica universa iuxta verum sensum et mentem Subtilis (w oryginale subtilium) Marianique Doctoris Duns Scoti exposita. Ad sacras vero aedes SS. Petri et Pauli Ap. Lublini explicata. Anno Domini 1760 a P. Simone a Lipnica p. t. philosophiae lectore".

Inc.: k. 2: „Nomen physicae vel physiologiae a graeco vocabulo $X$ a corpore authorem gratiae et gloriae experiamur...", k. 102.

2. k. 106-117. „Philosophiae aristotelico-scotisticae pars III videlicet metaphysica universa iuxta verum sensum et mentem Subtilis (w ory. ginale subtilium) Marianique Doctoris Joannils Duns Scoti exposita. Ad sacras vero aedes SSr. Petri et Pauli Apostolorum explicata Lublini. Anno Domini 1761:"

Inc.: k. 107: „Metaphysica secundum ethymologiam nominis derivatur X illas vero discutiendas theologis relinquimus", $k .117$.

Szkoła: Studium domesticum kapucynów w Lublinie. Lektor: o. Szymon Sikorski, kapucyn.

Reklamanty. Karty niezapisane: 102v, 106v, 117v. Spis treśc1 w porządku alfabetycznym na k. 103-105v. Na margınesach numery paragrafów. Ry-

69 Ur. 11 IIT 1708, do zak. wstapił 1724, zm. 30 III 1771 w Bialej Cerkwl. - Ks. J. B r o w n, JW s. 106-107; Enc. Chelm. III/IV 31; Pol. Stown. brogr I 189-190 (St. Bednarski); Ks. St. Z a1 ęs kl, Jw. T. 2 s. 635, J o c h e r nr 4722, 5006, 5010, 5446, 5453.

70 Ur. 13 VII 1728, do zak. wstąpir 1742. W czasie kasaty zakonu był w Lublinie. - Cat. pers. et offic. prow. Poloniae Minoris ex a. 1772 in a. 1773. Premisliae 1773 s. 13; B a c k e rSommervogel VII 1119-1120; Ks. J. Brown, Jw. s. 366 ; Fi t r. XXVIr $331-332$. 
sunek o wymiarach $33.5 \times 27.5$ to k. 76 zawierająca: "Totius corporeae machinae ex 12 caelis, et quatuor elementis compactae descriptio".

Składki: 10 seksternionów lecz 1 bez $1 \mathrm{k}$, 9 bez $4 \mathrm{k}$. wydartych.

Filigrany: Matka Boska z Dzieciątkiem w otoku promieni, na frontowej wyklejce. Motyw kwıatowy $z$ napısem: Iacob L B, na tylnej wyklejce. Tarcza herbowa $z$ korona 1 litera $U$ na dole, k. 1, 4. Matka Boska j. w. 1 korona pięciopałkowa $\mathrm{z}$ inicjałami A I u dolu, k. 67. Inicjały $G \mathrm{R}, \mathrm{k} .106$. Pod tarczą herbową z koroną inicjały i nazwiska: G R, J Honig, Zoon, k. 104. Inicjały H R, k. 102.

Oprawa półsztywna w tekturę. Grzbiet 1 rogi obciągnięte w sk. cielęcą, barwioną na brązowo a okładki papierem ręcznym marmurkowym, wykonanym klajstrowo. Szycie na 2 tasiemki.

Proweniencja: Biblioteka OO. Kapucynów. Kraków. Sygn.: $22 \mathrm{~J}-8$; $\mathrm{Nr}$ XI (o. Z. G.).

124. Łac. $1763-1765.21 .5 \times 16.5 \mathrm{~cm}$. K. 294. Opr. pksk. wsp.

1. k. 3-97v. „Philosophia rationalis seu logica iuxta mentem Mariani Doctoris Joannis Duns Scoti perducentis subtilitate sua alumnos suos felicit[er] in Scotiam. Exposita per AVP. Vitum Litomisliensem pro tunc lectorem philosophiae dignissimum. Tradita anno... 1764to mensis 7bris in Conventu Rosiampoliensi ad Sanctas Rosam et Rosaliam. Conscripta vero a me F. Aegidio Cap. ind[igno] $]^{:}$.

Inc.: k. 4: "Nota de omni re communiter solet fieri quaestio $\mathrm{X}$ quo nobilior eo frequentiori lectione ei invigillemus", k. $97 \mathrm{v}$.

2. k. 99-294. „Explanatio naturae hoc est philosophiae aristotelicae pars secunda videlicet physica universalis iuxta verum sensum ac mentem Subtilis Marianique Doctoris Venerabilis Joannis Duns Scoti. Explanata ac elucidata per A. Vdum Patrem Vitum Littomislensem pro tunc philosophiae lectorem dignissimum. Anno Domini 1765 tio die 4 ta 9 bris. In Conventu nostro Rosiampoliensi ad S. Rosam et Rosaliam. mps."

Inc.: k. 100: "Nota 1mo. Sicut in $1 \mathrm{ma}$ parte philosophiae nempe logicae X omnino delictum volo haec igitur cedat", k. 294.

Szkoła: Studium domesticum kapucynów w Rozjampolu (Uściług). Lektor: o. Wit Syrowy ${ }^{\mathbf{1}}$, Czech. Skryptor: o. Idzi Skiron.

Reklamanty. Numery paragrafów na marginesach. Nieliczne glosy marginalne. Inskrypcje: k. 97v: „17 maii 1765to“. Kolofon: k. 294: „Finita 16 februarii 1765 ad SS. Rosam et Rosaliam Rosiampoli".

Składkı: 37. Biniony 3, 4, 5, 6. Terniony 12 bez $1 \mathrm{k}$., 24. Kwinternion 18. Seksterniony $1,8,9,10,33$. Pozostałe kwaterniony lecz $2+1 \mathrm{k}$.

Filigrany: $w$ winietce litera $Z$ a ponad nia lew $w$ koronie $z$ mieczem, za nim rycerz $z$ kapeluszem na muszkiecie (?), z lewej strony w górze napis: Pro Patria, wyklejka frontowa i k. 1. Nazwiska: J Honig, Zoon, k. 7, 8. Tarcza herbowa $z$ koroną zakończoną jabłkıem z krzyżem; w tarczy trzy krzyże w pozycji pionowej i lwry, które podtrzymują tarczę, k. 2, 5. Matka

71 Ur. 4 III 1733, do zak. wstąpił 1754, zm, z8 VI 1609 w Rozwadowie. - CPP nr 186: Mortuologium, jw. 
Boska z Dzieciątkiem w otoku promieni, k. 249. Inıcjały J K P, k. 294. Wyklejka tylna $z$ napisem: J Honig, Zoonen.

Oprawa $w$ tekturę sklejaną $z$ makulatury rekopıśmiennej $z$ tekstem łacıńskım oraz druku polskıego XVII-XVIII w. Grzbiet i rogı zacıagnięte sk. bydlęcą barwioną na brązowo. Okładki obciągnięte papierem czerpanym w naturalnym kolorze. Szycie na 3 sznurkı. Dwie pary rzemienı do wiązania.

Proweniencja: 1. O. Idzi Skiron, kapucyn.

2. Biblioteka OO. Kapucynów. Kraków. Pieczątka okrągła na k. 2v 294v. Sygn.: 22 E-47; Nr LXXXIX (o.Z.G.).

125. Eac. 1764-1765. $24 \times 19 \mathrm{~cm} . K$. 106. Opr. ptsk. wsp.

1. k. $1-25 v$. ,Logica minor seu dialectica iuxta verum sensum et mentem Subtilis Marianique Doctoris Joannis Duns Scoti exposita. In qua summatim ea, quae ad logicae aliarumque scientiarum difficultates intelligendas necessario sunt praescienda, declarantur. A F. Simone a Lipnica ad sacras aedes Annuntiatae Virginis Cracoviae explicata 1764".

Inc.: k. 3v: "Tria sunt, quae spectant ad formam syllogismil $X$ et introductione ad logicam dicta sufficiant, cedantque...", k. 25v.

2. k. 27-106v. „Philosophiae aristotelico-scotisticae pars I videlicet logica universa iuxta verum sensum et mentem Subtilis Marianique Doctoris Joannis Duns Scoti ad sacras aedes Annuntiatae Virginis Cracoviae explicata. 1765“"

Inc: k. 28: "A dialectica seu summulis, quibus tandem $X$ ad maiorem Dei conservatoris habitum, dicta sufficiant", k. 99v.

Szkola: Studium domesticum kapucynów w Krakowie. Lektor: o. Szymon Sikorski.

Reklamanty. Karty niezapisane: k. 1v, 26, 27v, 100. Wklejki: k. 7, 8. Numery paragrafów na marginesach. „Axıomata philosophica alphabeto distincta“" na k. 101-102v. "Definitiones..." na k. 103-106v. Rysunki i wykresy: k. 15, 17, 23v, 24v. „Arbor porphyriana" na k. 65.

Skladki: 10. Ternion 10. Kwaterniony 8, 9. Kwinternion 3. Pozostale seksterniony.

Filigrany: korona pięciopałkowa $\mathrm{z}$ inicjałami A I, na wyklejce frontowej. Tarcza herbowa $z$ korona $i$ inicjałamı G R, k. 6. Mejżczyzna z mieczem przy boku, z pucharem $w$ prawej ręce, wznosi zdrowie drugiej osoby stojącej obok, wyklejka tylna.

Oprawa w tekture szara, szmacianą. Grzbiet i rogi obciągnıęte sk. cielęcą. Okładki obciagnięte papierem klajstrowym barwionym na brązowo. Szycıe na 2 rzemyki.

Proweniencja: 1. O. Szymon Sikorski, kapucyn.

2. Biblioteka OO. Kapucynów. Kraków. Pieczątka okrągła na odwrocie wyklejki frontowej i k. 1v, 106v. Sygn.: $22 \mathrm{~F}-25$; $\mathrm{Nr} X X I$ (o. Z. G.).

126. Eac. 1764-1766. $22 \times 18 \mathrm{~cm}$. K. 251. Opr. ptsk. wsp.

1. k. 1-28. "Logica minor seu dialectica iuxta verum sensum et mentem Subtilis Marianique Doctoris Joannis Duns Scoti exposita anno Dni 1764 ab Adm. V. P. Simone a Lipnica, in qua summatim ea, quae 
ad logicae aliarumque scientiarum difficultates intelligendas necessario sünt prraescienda, declarantur. Fr. Valentini Cap."

Inc.: k. 2: "Institutionis dialecticae cum sint fundamentum $\mathrm{X}$ ad logicam dicta sufficiant cedantque...", k. 28.

2. k. 29-126v. „Philosophiae aristotelico-scotisticae pars I videlicet iogica universa iuxta verum sensum et mentem Subtilis (w oryginale subtilium) Marianique Doctoris Joannis Duns Scoti. Ad sacras aedes Annuntiatae Virginis explicata".

Inc.: k. 30: „A dialectica seu summulis quibus $\mathrm{X}$ expulsa. Et haec de habitibuls...", k. 123.

3. k. 128-235. ,Philosophiae aristotelico-scotisticae pars II videlicet physica universa iuxta verum sensum et mentem Subtilis (w oryginale subtilium) Marianique Doctoris Joannis Duns Scoti exposita. Ad sacras vero aedes Annuntiationis B. V. Mariae explicata. Anno Dni 1765 ab A. V. P. Simone a Lipnica actuali lectore philosophiae".

Inc.: k. 129: „Nomen physicae vel physiologiae a graeco vocabulo $X$ a corpore authorem gratiae et gloriae experiamur...", k. 235.

4. k. 236-251. „Philosophiae aristotelico-scotisticae pars III videlicet metaphysica universa iuxta verum sensum et mentem Subtilis (w oryginale subtilium) Marianique Doctoris Joannis Duns Scoti exposita. Ad Sacras vero aedes Annuntiatae Virginis' Mariae explanata Cracoviae anno Dni $1766^{\prime \prime}$.

Inc.: k. 237: „Metaphysica secundum ethymologiam nominis derivatur $X$ illas vero discutiendas theologis relinquamus", k. $246 \mathrm{v}$.

Szkoła: Studium domesticum kapucynów w Krakowie. Lektor: o. Szymon Sikorskı. Skryptor: o. Walenty Wróblewskı.

Karty niezapisane: $1 \mathrm{v}, 28 \mathrm{v}, 29 \mathrm{v}, 127,235,236,247,251$. Numery paragrafów na marginesach. Nieliczne glosy marginalne. Rysunkı 1 wykresy: k. 16v, 18v, 19, 23, 26, 27. „Arbor porphyriana“" na k. 79v. Wkładka na k. 109; „Ex parochı S. Joannis Bap. absolvit Confessi[onem] Paschalem Anno 1770“. Inskrypcje: wyklejka tylna: „Epitaphium supra colonellum haereticum violenta morte extinctum".

Składki: 22. Biniony 3, 22. Pozostałe seksterniony.

Filigrany: rycerz stojący z mieczem $\mathrm{w}$ prawej ręce i szyszakıem $\mathrm{w}$ lewej, poniżej Inicjały I H K, k. 127, 235. 236.

Oprawa w tekturę. Grzbiet obciągnięty w sk. cielęcą barwioną na brązowo. Okładki obciągnięte papierem klajstrowym brązowym. $\mathrm{Na}$ grzbiecie linie tłoczone na ciemno, u góry sk. pęknięta i uszkodzona, również rogi okładki obdarte.

Proweniencja: 1. O. Walenty Wróblewski, kapucyn. Napis na k. 1.

2. Biblioteka OO. Kapucynów. Kraków. Pieczątka okrągła na k. 1v. Sygn.: $22 \mathrm{~F}-9 ; \mathrm{Nr} \operatorname{IX}$ (0. Z. G.).

127. Łac. 1765. $20 \times 16 \mathrm{~cm}$. K. 384. Opr. pt. wsp.

,Veritas [a] Joanne Duns Scoto aliisque tum veteribus tum recen- 
tioribus ductoribus pro schola capucina exposita. Sub lectore A. V. P. Zenone a. D. 1765... Fr. Primianus Cap. mmpp."

Inc.: k. 2: „Tametsi author ipse naturae bonorumque $\mathrm{X}$ clementiam, passim in scripturis legimus", k. 382v.

Treść: cz. I obejmuje filozofię scholastyczną, logikę, metafizykę, k. 1-151; cz. II zawiera fizykę ogólną, k. 151v-250v, 1 szczegółową, k. 251-382v.

Szkoła: Studium domesticum kapucynów, prawdopodobnie we Lwowle. Lektor: o. Zenon 'Tuma ${ }^{72}$, Czech. Skryptor: o. Prymian Chenczel ${ }^{73}$.

Reklamanty. Karty niezapısane: 369, 370r, 383, 384. Glosy marginalne. Tytuły i podtytuły wykonane pismem $\mathrm{w}$ formie liter drukowanych. Rysunki 1 wykresy: $274 \mathrm{v}, 275,371$.

Składkı: 33. Kwinterniony 14, 16. Septentrion 7. Pozostałe seksterniony lecz $3+1 \mathrm{k}$. Kustosze liczbowe od $1-26$, dalszych brak.

Filigrany: Matka Boska z Dzieciatkiem w otoku promieni, k. 6. Inicjały I C, k. 18. Lilıa, k. 373; dwie lilie, k. 384. Tarcza herbowa, w polowie tarczy półorzeł, k. 378, 379 .

Cprawa w tekturę półtwardą z makulatury łacińskiej, obciągnięta szarym płótrem żaglowym, naturalnym. Szycie na 3 sznurkı.

Proweniencja: 1. „Fr. Primianus Cap.". Napis na k. 1.

2. Biblioteka OO. Kapucynów. Kraków. Pieczątka olkragła na k. 1r, 382v. Sygn.: $22 \mathrm{E}-12$; Nr XIII (o. Z. G.).

128. Eac. 1765-1767. $20 \times 16.5 \mathrm{~cm} . K .161$. Opr. ptperg. wsp.

„Explanatio naturae hoc est philosophiae aristotelicae pars secunda videlicet physica universalis iuxta verum sensum ac mentem Subtilis Marianique Doctoris Venerabilis Joannis Duns Scoti explanata per AVP. Vitum Litomislensem p. t. lectorem dignissimum. Anno 1765 in Conventu Rosiampolensi die 4 novembris incepta. Conscripta per indignum discipulum Fr. Paulinum cle[ricum]".

Inc.: k. 2: „1. Nota $1 \mathrm{mo}$ sicut in prima parte philosophiae nempe $\mathrm{X}$ finita scriptione 1767 die 16 februarii Rosiampoli"*, k. 160v.

Szkoła: Studium domesticum kapucynów w Rozjampolu (Uściług). Lektor: o. Wit Syrowy, Czech. Skryptor: Paulın Stephen ${ }^{74} z$ Warmii.

Reklamanty. Karty niezapisane: 161. Nieliczne glosy marginalne. Na margınesach numery paragrafów.

Składki: 20. Terniony $12+2$ k., 13, 18. Seksternion 19. Pozostałe kwaterniony.

Filigrany: Matka Boska $\mathrm{z}$ Dzieciattkiem w otoku promieni, k. 3. Korona pięciopałkowa $z$ inicjałami I A, k. 4, 5. Rycerz na koniu, frontowa wyklejka.

Oprawa w tekturę sklejana z makulatury polskiej. Grzbiet pergaminowy z trzema więzami. Okładka obcıagana papierem klajstrowym barwionym na czerwono. Rzemykı do wiązanıa, dwie pary. Brzegi zielone.

72 Ur. 6 XII 1736, do zak. Wstapil 1756, zm. 4 VIII 1783 w Krakowie. - CPP nr 210; Mortuologium, Jw.; O. Z. Gorl $1 \mathrm{cki}$, JW. s. 263-264.

${ }_{3}$ Ur. 19 VIII 1743, do zak. Wstąpil 1763, 2m, 5 III 1808 w sędziszowie. - CPP nr 304: Mortuologium, jw.

" Ur. 23 III 1738, do zak. wstapił 1762, zm. 13 III 1775 w Krakowle. - CPP nr 291; Mortuologium, jw. 
Proweniencja: 1. „Fr. Paulinus, clericus“. Napis na k. 1.

2. Biblioteka OO. Kapucynów. Kraków. Pieczątka okrągła na wyklejce frontowej i k. 161v. Sygn.: 22 C-38; Nr LXXVII (o.Z. G.).

129. Łac. $1766.20 .5 \times 16.5 \mathrm{~cm}$. K. 189. Opr. płsk. wsp.

„Pars 1ma physicae seu physica generalis continens explicationem tum essentiae et principiorum corporis tum generalium qualitatum eius. que affectionum".

Inc.: k. 1: „Per rationem formalem corporis generice accepti $\mathrm{X}$ anima excitet ad diversos colores percipiendos", k. $189 \mathrm{v}$.

Szkoła: Kolegium jezuıtów w Krasnymstawie. Profesor: o. Andrzej Słabnıewicz ${ }^{75}$.

Reklamanty. $\mathrm{Na}$ margınesach numery paragrafów. Glosy marginalne 1 interlinearne. W dolnej części rękopisu wyraźne ślady dawnego zamoczenıa i wilgoci.

Składkı: 48 bınıonów lecz 1 bez $2 \mathrm{k}$.

Filigrany: Matka Boska z. Dzıec1ątkıem w otoku promieni, k. 1, 2. Inicjały G M, k. 4. Zdobnik z inicjalami C N, k. 99.

Oprawa w tekturę. Grzbiet 1 rog obciągnıęte sk. cıelęcą barwioną na brązowo. Okladkı obciagnięte kolorowanym papierem czerpanym grzebienıwym. Szycie na 2 więzy. Brzegi silnıe nakrapıane na czerwono.

Proweniencja: Biblioteka OO. Kapucynów. Kraków. Pieczątka okrągła na wyklejce frontowej i wyklejce okładki tylnej. Sygn.: $22 \mathrm{E}-28$; Nr XIX (o.Z. G.).

130. Łac. 1766. $20 \times 16.5 \mathrm{~cm}$. K. 120. Opr. ptsk. wsp.

„Institutiones philosophicae usui scholarum ac faciliori tum veterum tum recentiorum philosophorum intelligentiae accomodatae dissertationibus scholasticis ad faciliorem disputandi methodum illustratae... In Scholis Crasnostaviensibus Collegii S. J. 1766 in 7mum die $1 \mathrm{ma}$ septembris".

Inc.: k. 1v: „1mus. Philossophia vi vocis amorem aut stuldium $\mathrm{X}$ actus ex hoc motivo formati. Urgebis 2 do suo entis...", k. $120 \mathrm{v}$.

Treść: kodeks składa sıę z dwóch części. Pierwsza: „logica minor seu directa“, k. 3-55; druga ,logica malor seu reflexa“, k. 57-120v.

Szkoła: Kolegium jezuitów w Krasnymstawie. Profesor: o. Andrzej Słabniewicz. Skryptor: Antoni Korzenıowski ${ }^{76}$, późnıejszy o. Alojzy Korzeniowski, kapucyn.

Reklamanty. Karty niezapısane: 55v, 56. Na marginesach numery paragrafów. Inskrypcje: k. 55: „,31 8bris“. Glosy marginalne: k. 118.

Składki: 31 binionów.

Filigrany: Matka Boska z Dzieciątkıem w otoku promıeni, k. 5, 6. Inicjaly: I A, k. 11.

75 Ur. $24 \times$ 1722, do zak. Wstąpił 1742. W czasıe kasaty zakonu przebywå w Eucku. W r. 1766 uczyl w Krasnymstawie. - Cat. I Coll. Sandomiriensis S. J. 1770; ArSI, Pol. 37 f. $127 \mathrm{nr} 2$.

${ }_{78}$ Ur. 19 VI 1746, do zak. OO. Kapucynów wstąpił 1774, zm. 1 V 1805 w Dunajowicach. CPP nr 363. Od r. 1764 byl alumnem jezuitów; w czasie kasaty tegoz zakonu był jeszcze klerykıem. Cat. Prov. Polonıe Minoris S. J. 1773 (Premisliae) podaje inną datę urodzenıa: 10 VI 1747. 
Oprawa w tekturę. Grzbiet i rogi obcıągnięte sk. cıelęcą barwioną na brązowo. Na grzbiecıe linie tłoczone na cıemno. Okładki obciągnięte papierem czerpanym, grzebieniowym na karagenie. $\mathrm{Na}$ okładce tylnej przyczepiona kartka z napisem: „Pro Fratre Aloys.10". Szycie na 2 szmurki. Brzegl czerwone.

Proweniencja: 1. O. Alojzy Korzeniowski, kapucyn.

2. Biblioteka OO. Kapucynów. Kraków. Pieczątka okragła na odwrocie okładki frontowej $\mathrm{i} k$. 120v. Sygn.: $22 \mathrm{E}-13$; Nir XVIII (o. Z. G.).

131. Łac. $1766-1768.20 .5 \times 16.5 \mathrm{~cm}$. K. 153. Opr. plsk. wsp.

Physica generalis.

Inc.: $\mathrm{k}$. 1: ,vere non conveniat. Obiicitur: ratio formalis corporis $\mathrm{X}$ corporum de calore ac de sapore et motus localis", k. $153 \mathrm{v}$.

Kodeks bez tytułu i kart początkowych. Kolejny numer marginalny bıeżącego zagadnienıa wskazywałby na dalszy cıąg z pierwszego tomu. Kodeks bowiem oprawiony został $w$ takıej postaci, w jakıej się obecnie znajduje. Tak ręka, papıer, układ graficzny bloku 1 kart, jak wreszcie oprawa prowadziłyby wyraźnie do kolegıum jezuickıego w Krasnymstawie w 1. 1766-1768. Rékopis zawiera prawdopodobnie wylkłady o. Wojciecha Filkiewicza ${ }^{77}$ i być moze został napisany przez Antonıego Korzeniowskiego późniejszego kapucyna o. Alojzego Korzeniowskiego.

Reklamanty. Numery marginalne bieżących zagadnıeń. Glosy margınalne i interlmearne. Brak łońca, ostatnıa karta oderwana,

Składki: 38 binionów.

Filıgrany: Matka Boska z Dzıeciątkiem w otoku promıenı, k. 2, 3. Inıcjały I A, k. 4. Zdobnik z inıcjałamı C N, k. 147.

Oprawa jak pod nr 130 .

Proweniencja: Biblioteka OO. Kapucynów. Kraków. Sygn.: $\mathrm{Nr}$ IV (o. Z. G.).

132. Łac. $1767.20 .5 \times 16.5 \mathrm{~cm}$. K. 146. Opr. brosz. wsp.

„Philosophia mentis seu metaphysica scholasticis disputationibus illustrata. Atque ad usum auditorum accomodata... per Rdum Patrem Adalbertum Filkiewicz 20 maii 1767. In Schollis: Crasnostaviensibus Collegii Soc. Jesu. Scripta per Antonium Korzeniowski S. J."

Inc.: k. 1v: ,Metaphysica nomen antiquis philosophis ignotum X nos vero dissertationibus metaphysicis finem facimus", k. 146.

Szkoła: Kolegium jezuntów w Krasnymstawie. Profesor: o. Wojciech Filkiewıcz. Skryptor: Antonı Korzeniowskı, późniejszy kapucyn o. Alojzy Korzen1owski.

Reklamanty. Numery paragrafów na margınesach. Glosy marginalne i interlinearne. Na każdej stronie w górnej części marginesu znak JMJ.

Składk1: 37 binionów lecz $37 \mathrm{bez} 2 \mathrm{k}$. wydartych.

Filıgrany: Matka Boska z Dzıeciątkiem w otoku promeni, wyklejka frontowa, k. 23. Inicjały G M, k. 1; A I, k. 138.

Brulion rękopisu oprawny w sklejaną makulaturę. Grzbiet był obciągnięty papıerem barwionym na zıelono, jak 1 rogı a okıladki zwykłym papierem czerpanym. Na tylnej okładce silny ślad plamy z odparzenia. Szycıe na 3 sznurki.

7 Ur. 28 IV 1728, do zak, wstąpil 1744, zm. przed r. 1773. - Cat. I Coll. Sandomiriensis S. J. 1770; ArSI, Pol. 37 f. $136 \mathrm{nr} 2$. 
Proweniencja: 1. O. Alojzy Korzeniowsku, kapucyn.

2. Biblioteka OO. Kapucynów. Kraków. Pieczątka okrągła na k. 1v, 146v. Sygn.: $22 \mathrm{E}-9$; $\mathrm{Nr} X X$ (o. Z. G.).

133. Eac. 1796. $20 \times 17.5 \mathrm{~cm}$. K. 130. Opr. płsk. wsp.

„Philosophiae in logicam, metaphysicam et physicam divisae succinctum compendium. Ex quibusdam selectoribus tum antiquis tum recentioribus auctoribus pro usu et commodo scholastico religiosae nositrae iuventutis Ordinis Minorum S. P. Francisci Capucinorum per R. Patrem Thadaeum eiusdem Ordinis pro tunc lectorem collectum. In Conventu nostro Cracoviensi anno a Partu Virginis 1796“.

Inc.: k. 4: „§ 1. Philosophia si nomen 1psum ex graecis vocalibus compositum X Francisci honorem venerationem et laudem cedant", k. $128 \mathrm{v}$.

Szkoła: Studium domestıcum kapucynów w Krakow1e. Lektor: o. Tadeusz Krawczyński.

Reklamanty. Paginacja oryginalna: nlb. 6, 250, nlb. 4. Karty niezapisane: $1,2 v$. Glosy interlnearne. Karta tytulowa w potrójnej ramce z prostych linii.

Składki: 32 biniony.

Filigrany: biskup z pastorałem, k. 1. Inıcjały: C G N, k. 9.

Oprawa w tekture szarą. Grzbiet i rogi obciągnıęte sk. cielęcą barwioną na brązowo. Okładkı oklejone papierem ręcznym klajstrowym, marmurkowym. $\mathrm{Na}$ grzbiecıe szyldzik ze skórki jasno brązowej, ozłoconej rameczką z ty tułem „Philos. metaph." złoconym ręcznie. Wskutek dawnej wilgoci oprawa uszkodzona. Szycie na 3 sznurkı. Brzegı czerwone.

Proweniencja: 1. O. Tadeusz Krawczyński, kapucyn.

2. Bibliatekia OO. Kapucynów. Kraków. Pieczątka okrągła na k. 1v i wyklejce tylnej. Sygn.: $22 \mathrm{E}-8$; Nr LXX (o. Z. G.).

134. Łac. II pot. XVIII w. $22 \times 17 \mathrm{~cm}$. K. 224. Opr. ptsk. wsp.

„Physica sive philosophia naturalis".

Inc.: k. 3: „Physica secundum vim nominis a graeco $\mathrm{X}$ folia informantur aurum, quia illam...", k. 224v.

Rękopis został napisany po r. $1750 \mathrm{w}$ jednym $\mathrm{z}$ ośrodków naukowych czeskich być może w którymś $z$ czeskıch klasztorów kapucyńskıch. Hipotezę powyższą potwlerdza notka na k. 193v: „Et tandem 1750 die 3 februarii, quod Litomislii 3 et ultra horıs observare licuit". Za pośrednictwem kapucynów czeskich rękopis znalazł sı̨ w Polsce i prawdopodobnie posługiwano się nim w miejscowych uczelniach filozoficznych. Kodeks nie posiada karty tytułowej ani końca. Tytuł nagłówkowy (k. 2), nagłówki rozdziałów i podrozdziałów, pytanıa, paragrafy zagadnień rubrykowane. Liczne rysunkı i wykresy.

Składki: 19.19 kwatemion, pozostałe seksterniony.

Filigrany: papıer tak przycıęty, że fragment filigranu znajduje sıę w lewym górnym lub dolnym rogu karty. Inicjał I F, na wyklejce frontowej. Matka Boska z Dzieciątkiem w otoku promieni, na wyklejce tylnej. Fragment strzały, k. 2. Litera: P, k. 4.

Oprawa w tekturę. Grzbiet obciągnięty sk. brązową a okładki papierem czerpanym barwionym techniką klajstrową. Brzegi czerwone. 
Proweniencja: Biblioteka OO. Kapucynów. Kraków. Pieczątka okragła na k. iv, 224v. Sygn.: $22 \mathrm{~F}-8$; $\mathrm{Nr}$ VIII (o. Z. G.).

135. Łac. 1819. $19 \times 12 \mathrm{~cm}$. K. 69. Opr. brosz. wsp.

„Institutiones logices iuxta authorem praescriptum Universitatibus in ditionibuls Austriacis existentibus Joannem Georgium Henricum Federum explanatae. Iuventuti seraphicae traditae anno Dni 1819".

Inc.: k. 1: „Relate Pythagoreorum omnes ii qui alicui sacrae $\mathrm{X}$ ergo si organa nostra aliter constituunt", k. 69.

Reklamanty. Karty niezapısane: k. 69v. Rękopis opracowany dwiema rękami.

Składki: 9. Terniony 2, 7. Pozostałe kwaterniony.

Filigrany: fragmenty niezidentyfikowanego filigranu $\mathrm{w}$ lewym górnym rogu karty.

Oprawa w tekturę obciagniętą w całości papierem czerpanym, siwym. Szycie na 3 tasiemki.

Proweniencja: 1. „Szymańșiki Benji[amin]", kapucyn; k. 69r.

2. Biblioteka OO. Kapucynów. Kraków. Sygn.: Nr XXIV (o.Z.G.).

136. Eac., pol. $1841.23 .5 \times 19.5 \mathrm{~cm}$. K. 99. Opr. brosz. wsp.

„Prolegomena universae philosophiae authore Patre Hermano Osterrieder Ordinis S. Patris Francisci Conventualium lectore ordinario Studii Minoritici Ratisbonensis anno Domini $1760 "$.

Inc.: k. 1: „Q. Quid et quotuplex cognitio rerum in genere $\mathrm{X}$ praeditus, ergo avarus nom est dives", k. 94.

Rękopis napisany, być może, przez o. Wojciecha Patlę, kapucyna.

Reklamanty. Paginacja oryginalna: 148, nlb. 50. Karty niezapisane: 94v, 95-99.

Składki: 9. Binion 1. Kwinternion 7. Seksterniony 2, 3, 4, 5, 8, 9 bez $3 \mathrm{k}$. Septentrion 6.

Filigrany niezidentyfikowane.

Oprawa w tekturkę. Grzbiet i okładki obciągnięte papierem marmurkowym fabrycznym (Pappband). Szycie na 3 sznurki. Brzegi nakrapiane na niebiesko.

Proweniencja: 1. „Fr. Adalbertus a. 1841.“. Napis na k. 1.

2. Biblioteká OO. Kapucynów. Kraków. Pieczątka okrągla na wyklejce frontowej i k. 94v. Sygn.: $22 \mathrm{~F}-22$; $\mathrm{Nr}$ XXII (o. Z.G.).

137. Łac. I pol. $X I X$ w. $17 \times 10 \mathrm{~cm}$. K. 62. Opr. brosz. wsp.

„Compendium physicae generalis".

Inc:: k. 1: "In illuminato intellectu nostro regulis artificialibus $\mathrm{X}$ Maria scholae marianae magistra et finis", k. 56 .

Spis treści: k. 59-62.

Składki: 8. Binion 8. Kwinternion 7. Pozostałe kwaterniony. karty.

Filıgrany: fragment niezidentyfikowanego filigranu w gómej lewej części 
Oprawa broszurowa obciagnięta w calości papierem czerpanym, siwym. Brak grzbietu. Szycie na 2 sznurki.

Proweniencja: Biblioteka OO. Kapucynów. Kraków. ,Sygn.: Nr XVI (o.Z. G.).

138. Eac. I pot. XIX w. $20 \times 17 \mathrm{~cm} . K .52$. Opr. płsk. wsp.

„Prolegomena universae philosophiae".

Inc.: k. 2: „Nota 1mo. Sciendum vocem philosophia ortum esse a Pytagora $X$ nil fuit unquam sic impar" sibi", k. 52 .

Rękopis został opracowany prawdopodobnie przez kleryka Samuela Brzuchowskiego ${ }^{78} \mathrm{w}$ jednym ze studiów filozoficznych prowadzonych przez kapucynów w Polsce.

Karty niezapisane: 1, 8v, 52v. Liczne glosy marginalne. Bez karty tytułowej. Karta 8 jest wklejką z rysunkami: ,arbor Porphyrii“" i ,arbor Cartesiana aut Purchotiana“. $\mathrm{Na}$ frontowej wyklejce znajduje sıę tekst modlitwy odmawianej $w$ studium przed rozpoczęcıem naukı.

Składki: 14. 3, 4, 14 mają po $2 \mathrm{k}$. Pozostałe bınıony lecz $2+2 \mathrm{k}$.

Filigrany: fragment wielkıego orła, na wyklejce frontowej i tylnej. Inicjały J W PI, k. 2. Duży orzel w koronie z jabłkıem i berłem, k. 3, 4. Nazwa: Willenberg, k. 5. W podwójnym owalu gryf, k. 8.

Oprawa w tekturę. Grzbiet i rogi sk. barwiona na brazowo. Okładki obciagnięte kolorowanym papıerem czerpanym $z$ nadrukiem $z$ ornamentem k6łek (tłoczonych może techniką drzeworytniczą). Szycıe na 2 więzy na paskach skórzanych.

Proweniencja: 1. „Ad usum Fr. Samuelis Ord. Capucinorum". Napis na wykilejce frontowej.

2. Biblioteka OO. Kapucynów. Kraków. Sygn.: $22 \mathrm{E}-7$; $\mathrm{Nr}$ II (o. Z. G.).

\section{HISTORIA POWSZECHNA}

139. Eac., pol. $1770.16 .5 \times 10 \mathrm{~cm}$. S. 12. Bez opr.

„Brevis relatio de origine, progressu, statu, regulis ac ceremoniis francmassonorum".

Inc.: s. 1: „Originem suam ducunt illi liberi murarii $\mathrm{X}$ forma absolutionis sacramentalis propter haeresim", s. 8.

$\mathrm{Na}$ karcie tytulowej informacja: „Inventa in Archivo RR. PP. Capucinorum Conventus Cracoviensis“. Od s. 9 tekst w jęz. polskim pochodzący z końca XVIII w.

Proweniencja: Biblioteka OO. Kapucynów. Kraków. Pieczątka owalna na k. tytułowej $i$ wyklejce tylnej, okragla na $k$. tytulowej, s. 9,12 , Sygn.: $h-102$ : $20 \mathrm{~A}-38$.

140. Pol. 1781. $19.5 \times 13 \mathrm{~cm}$. S. 26. Bez opr.

„Reformacja w Niemczech przy końcu wieku ostiemnastego. W Wiedniu $1781^{\prime \prime}$.

Inc.: s. 1: „Kraje i diobra, które długo lub krótko posiarali X iniewypróborwane zwyczaje odkryte i powoli zgłardzone będa" , s. 26.

Proweniencja: Biblioteka OO. Kapucynów. Kraków.

${ }_{78}$ Ur. 13 VIII 1788, do zak. wstąpil 1307, 2m. 9 I 1830 w Lubartowie. - CPP nr 477; Mortuolog:um. Jw. 
141. Pol., franc. 1853. $34 \times 21 \mathrm{~cm}$. S. 578. Opr. ptsk. wsp. „Dokumenta do historii polskiej z epoki od 1790 do 1794 roku".

Inc.: s. 1: „W panowaniu Stanisława Augusta co uderza zapewne każdego X zaleceniem Komisji Skarbu Koronnego względem starostwa żarnowieckiego", s. 577.

Tytul na etykietce frontowej okladki nieczytelny. Na k. tytulowej znajduje się: „Objaśnienıe: $\mathrm{W}$ roku 1794 podczas insurekcji w Warszawie, poseł rosyjskı jenerał Ingelström rozkazał spalić akta ambasady. Że szturmowano do pałacu na ulicy Miodowej w którym mieszkał, nie miano czasu spalıć $\mathrm{w}$ zupełności te akta. Po zdobyciu tego pałacu oddano resztę papierów ambasady do tak zwanego Wydziału Bezpieczeństwa to jest najwyższej władzy policyjnej, na której czele znajdował się mój teść JW. Michał Kochanowskı. Prócz tego złożono $\mathrm{w}$ tymże Wydziale znalezione papiery po powieszonym w Warszawie Kossakowskim biskupie inflanckim. Na konıec, gdy do wytoczonych procesów osobom uwıęzionym a należącym do składu Rady Nieustającej i Ministeryjum pościągano do tegoż Wydziału akta Rady Nieustającej to jest protokołu posiedzeń jej 1 akta Sejmu Grodzıńskıego. Te wszystkie papiery mımo że jenerał Suworow po zdobyciu Warszawy o nie reklamował, teść mój u siebie przechowal a umierając w $\mathrm{r}$. 1833 mnie ich darowal. $\mathrm{Z}$ tych papierów sprzedałem przez pośrednıctwo Aleksandra Batowskıego J. Wielmożnemu Dzieduszyckiemu rachunki kasy przeprowadzone przez Xięcra Wołkońskiego i decyzyje Rady Najwyższej w sprawach przeciwko Ferdynandowi Moszyńskiemu i biskupowi Skaryszewskıemu za zł. polskich 4500, reszte tych papıerów zakupił JW. Andrzej Zamoyski za zł. 22000. Musıałem zaś je sprzedać, bo sam zostawałem pod nader ścisłym dozorem policyjnym przez blisko lat 25 i obawiałem się, że przy lada rewızji papiery te zostaną skonfiskowane. Lecz dla pamiątki, ważniejsze rzeczy w treści a czasem dosłownie wypisałem. To co zakupił JW. Dzieduszyckı, zapewne w jego księgozbiorze przechowuje sıę, lecz to, co nabył JW. Zamoyskı, wielkie prawdopodobieństwo, ze zniszczonem zostało w czasie kiedy pałace jego uległy co do mobilijów jego 1 lokatorów zupełnemu zniszczeniu. Ta treść i wypısy, które sam najwierniej poczyniłem, jest więc jedynym śladem, jaki pozostał z tych szacownych dokumentów historycznych. Leon Dembowsk1 ${ }^{796 .}$. Dopısek ręką o. Wacława Nowrakowskiego: „(kasztelan) ojcıec Edwarda, który zginął pod Gdowem 1846“.

Blok rękopisu składa się z cienkiego papieru szarego 1 zielonego. Strony niezapisane: 19, 20, 54, 57, 58, 119, 163, 164, 188, 202, 203, 204-216, $220,374,375,376,478,479,480,578$. Glosy wykonane ołówkiem przez o. Wacława Nowakowskiego, który wykorzystał rkps w swoich pracach historycznych, podobnie jak 1 prof. Wacław Tokarz. Od czasu do czasu pod aktami wıdnieje podpis L. Dembowskiego, stwierdzającego zgodność kopii z oryginalem.

Składki najczęściej $\mathrm{z}$ dwóch stron. Kustosze liczbowe w prawym górnym rogu strony.

Oprawa w tekturę obctągniętą płsk. cielęcym barwionym na brązowo. Sk. na grzbiecie częściowo oderwana i zniszczona.

Proweniencja: 1. Leon Dembowskit.

2. O. Waclaw Nowakowski.

79 Por. Pol. Stown. bıogr. V 93-95 (E. Wawrzkow1ez). 
3. Biblioteka OO. Kapucynów. Kraków. Pieczątka owalna na s. tytułowej, 219, 221, 371, 464, 576, 577. Pieczątka okrągla: Archiwum Prowincji Krakcowskiej OO. Kapucynów, na etykietce olkładki frontowej i s. 576, 577. Sygn.: V-497.

142. Pol., franc. $1792-1817.22 \times 14 \mathrm{~cm}$. S. 117. Bez opr.

„Zbiór kopii dokumentów z akt wojskowych od r. 1792 do 1815,pozostałych po jenerale śp. Józefie Niemojewskim" ${ }^{80}$.

Inc.: s. 1: „Tygodnik Ilustrowany N. 143 z r. 1885 zamieścił w swych szpaltach opis bitwy pod Raszynem X najjaśniejszy cesarz i król akordować raczył dymisję $z$ pensją odstawkową. Dan $w$ Warszawie d. 3/15 marca 1817 r. Naczelny wódz Konstanty“, s. 117.

Syn generała Niemojewskiego wykonał odpis, względnie streszczenie dokumentów I akt na podstawie archiwum rodzinnego po r. 1885. Podwójne kartkı rękopısu zwıązane nicıą z papıerowa obwolutą. Rękopis wykorzystany prawdopodobnie przez o. Wacława Nowakowskiego i prof. Wacława Tokarza. S. 117 niezapisana. S. 51 przedłużona przez naklejenie karty. S. 117 oddarta.

Proweniencja: Biblioteka OO. Kapucynów. Kraków. Pieczątki na karcie obwoluty, s. 1, 32, 115. Sygn:: $\mathrm{r}-82$.

143. Pol., łac. $1793-1811.35 \times 20.5 \mathrm{~cm}$. S. 291. Opr. ptsk. wsp.

,Kontynuacja dalsza historii domowej, krajowej i zagranicznej od dnia 31 lipca roku 1793“. (Do r. 1811).

Inc.: s. 1: „Marszałek sejmowy zagaja sesję od wprowadzenia X pokrzywdzonym ten dom, ani obrońcy ani mściciele", s. 291.

Etykietka na frontowej okładce bez żadnego napisu. Rękopis w zasadzie miał służyć do spisywanıa kronikı domu zakonnego pijarów w Krakowie. Sprawy zakonne potraktowano jednak fragmentaryicznie, natomiast obszernie zajęto się zagadnıeniem insurekcji kościuszkowskiej i okresem napoleońskim. Rękopis wykorzystany tak przez o. Wacława Nowakowskiego, jak i prof Waclawa Tokarza. Reklamanty. W pagınowanıu kronikarz pomylił się i zamiast s. 38 wpisał 39. Na wyklejce frontowej podpıs: Slızowsk1.

Składk1: 14. Kwaterniony 6, 8, 10, 12, 14. Kwinterniony 1, 2, 4. Seksterniony $3,5,7,9,11,13$.

Oprawa w tekture, płsk. cielęcy kolorowany na brązowo. Grzbiet popękany z brakamı skóry. Szycie na 2 więzy.

Proweniencja: 1. Kolegium pijarów w Krakowie.

2. O. Waclaw Nowakowski.

3. Biblioteka OO. Kapucynów. Kraków. Pieczątka owalna na etykietce okłađaki frontowej, ma wyklejce frontowej, s. 1, 241 i wyklejce tylnej. Sygn.: V - 498 .

144. Franc. I pot. XIX w. $25 \times 19.5 \mathrm{~cm}$. S. 16. Bez opr.

„Niektóre kopie manuskryptów X. Hugona Kołłątaja“.

Inc.: s. 1: „Aperçu de la situation politique de la Russie en général $X$ il faut bien prendre garde à haute la famille de Kossakowski", s. 16.

Na karcie tytułowej napis: „Wielmożnemu Antonıemu Kamieńskiemu ${ }^{81}$

so Enc. Orgelbr. XIX 418-419.

81 Es t r. II 339. 
profesorowi Liceum św. Anny w Krakowie, ofiaruje Ferdynand Kojsiewicz ${ }^{8.4}$, prof. U. J.

Proweniencja: 1. Ferdynand Kojsiewicz.

2. Antoni Kamieński.

3. Bibliotekla OO. Kapucynów. Kraków. Pieczątka owalna na k. tytułowej s. 1,5 , 16. Sygn.: $1-67$.

145. Pol. I pot. XIX w. $28 \times 22.5 \mathrm{~cm}$. S. 28, nlb. 2. Bez opr.

„Rzut oka na stan polityczny Królestwa Polskiego pod panowaniem rosyjskim przez ciajg lat 15 od 1815-1830“.

Inc.: s. 1: „Kiedy w kolei wieków Europa po tylekroć zmieniała swą postać polityczną $X$ tylko senat przez okazantile powolności w zdaniu zasłużył na jego zaufanie".

Proweniencja: Biblioteka OO. Kapucynów. Kraków. Sygn.: $R-86$.

146. Pol. $1870.21 .5 \times 17.5 \mathrm{~cm}$. K. 66. Opr. ptpt. wsp.

1. k. 1-28v. ,Zapiski bibliograficzne o manuskryptach, inkunabułach, o dawnych drukach polskich przejrzanych $w$ bibliotece miasta Gdańska przez X. Ignacego Polkowskiego".

Inc.: k. 1: „Rozproszeni po świecie całym, rozproszone tez mamy $\mathrm{X}$ ciekawych biblitotek publicznych i prywatnych zbiorów", k. 28v.

2. k. 29-31v. „Dopisek. Wiadromość o bibliotece gdańskiej Jana Uphagena przez tegoż autora“.

Inc.: k. 29: „Oprócz opisanej przez nas biblioteki gdańskiej X Polonica. 165. Annales Stanislai Orichovii“, k. $31 \mathrm{v}$.

3. k. 32-66v. „Krzysztof Stanisław Janikowski fałszerz dokumentów polskich w XVII wieku".

Inc.: k. 32: „W czasie mego ostatniego pobytu w Krakowie X bacznej uwagi na podejrzane dokumenta", k. 66v.

Materiały do historii Polski zebrane przez ks. Ignacego Polkowskiego ${ }^{83}$. Pisane w r. $1870 \mathrm{w}$ Lubostronıu. Glosy interlınearne pochodzące od o. Wacława Nowakowskiego, k. $1-5 \mathrm{v}$.

Oprawa brulionowa $w$ tekturkę. Grzbiet obciągnięty czarnym płótnem kaliko, papier marmurkowy.

Proweniencja: 1. O. Waclaw Nowakowski.

2. Biblioteka OO. Kapucynów. Kraków. Pieczątka owalna i okrągla na vylklejce frontowej, k. 1, 52, 66v. Sygn.: $1-157 ; 35 \mathbf{E}-30$.

\section{PRAWO SWIECKIE}

147. Eac., pol. I pot. XVIII w. $20.5 \times 14.5 \mathrm{~cm}$. K. 182. Opr. sk. wsp. 1. k. 1-140v. ,Introductio ad doctrinam civilem. Liber I. De con-

82 Ur. 1801, zm. 14 IV 1874 w Krakowie. Prawnik, prof. UJ - Wielka enc. ilustr. XXXVI XXXVI 988; Estr. II 405; L. F $1 \mathrm{nk}$ el: Bibllografia historii polskiej. Cz. 1. Lwow 1891 poz. 50, 217, 22047; Ks. T. G 1 e m m a : Wydzlal Teologiczny Unıwersytetu Jiglellonskiego w latach 1795-1847. Kraków 1949 s. 152, 161; W. Wą s 1 k, JW. s. 361; W1. W s s o ck 1, jw. nr 1039, 1040, $1042,1043,1044,1816,2881-2884,2928,2942,2946,3027-3029,4096$.

ss Ur. 4 IV 1833, wysw. 1857, zm. 27 VIII 1888. Historyk. - Enc. Now. XX 262-263; Es t r. III 453-454; L. F $1 \mathrm{n} \mathrm{k}$ el, Jw. Cz. 2 s. 2109 (wykaz prac); Wł. W $1510 \mathrm{ckl}$, Jw. nr 999, 3636, 3756. 
stitutione Reipublicae". K. 44: „Liber II. De administratione Reipublicae". K. 78v: „Liber III. De arte, scientia qua Reipublicae administratio exercetur".

Inc.: 1: „§ 1. Politica nomen habet a graeco polis scilicet $\mathrm{X}$ praesit decanus qui caput contubernii nominetur"s, k. $140 \mathrm{v}$.

2. k. $142-169 \mathrm{v}$. Mowy na sejmach i sejmikach.

Inc.: k. 142: „Od :tego województwa, które zawsze prae oculis $\mathrm{X}$ referant dum pia facta vident", k. 169v.

3. k. 176-180. „Caput XVI. Nullis novis causis“. Dalszy ciagg pozycji nr 1.

Inc.: $\mathrm{k}$. 176: „Vix contingit mutatio regiminis, aut novus $\mathrm{X}$ ad seditionem, quod est crimen laesae maiestatis".

Kodeks spisany jedną ręką $z$ wyjątkiem czẹścı 2. Reklamanty. W części 2 margines boczny częściowo zapısany.

Oprawa twarda w tekturę szmacianą, obcıągnięta w sk. cielęcą, barwioną na brązowo. Grzbiet wzmocniony paskami pergaminowymi i zamalowany farbą popielatą $z$ tytułem w górnej części: „De republica“. Szycie na 5 więzów, przeclagganych przez tekture. Brzegl marmurkowe w kolorze granatowym. Kapitałka wyszywana jedwabiem białoniebieskım.

Składki: 14. Ternion 14. Kwinterniony 1, 3, 5, 12, 13. Seksternion 9. Septentrıony 2, 4, 7,11 . Okternıony 6, 8. Składka $10 \mathrm{ma} 20 \mathrm{k}$.

Filigrany: glowa niewiasty $w$ czepku $z$ dwoma pomponami i kryzą wokoło szyi, u dołu znak $w$ formie $4 \mathrm{z}$ trzema kółkami, k. 180, 181.

Proweniencja: 1. „PP. Capucinorum Mariampoliensium. 1763“. Napis na k. 1.

2. Bibalioteka OO. Kapucynów w Olesku. Pieczątka .okrąła na k. 1, 51, 143 .

3. Biblioteka OO. Kapucynów. Kraków. Pieczątka okrągła na odwrocie wyklejki frontowej, k. $122 \mathrm{v}, 179 \mathrm{v}$.

148. Pol. 1879-1880. $20 \times 16.5 \mathrm{~cm}$. S. 254. Opr. plpt. wsp.

„Procesy szczególne. Wykład prof. dra [Edwarda] Fiericha ${ }^{84}$. 1879/1880".

Inc.: s. 4: „Pojęcie procesu podaliśmy w części pierwszej X postanowień wymaga znajomości prawa górniczego", s. 254.

Skrypt litografowany.

Oprawa zeszytowa $\mathrm{z}$ płóciennym grzbietem.

Prowreniencja: 1. Pruszyńskiki. Podpis na wyklejce frontowej.

2. Biblioteka OO. Kapucynów. Kraków. Pieczątka okrągła na s. 2, 254.

DYDAKTYKA I PEDAGOGIKA

149. Pol. 1898-1899. $21 \times 17 \mathrm{~cm}$. K. 237. Opr. brulionowa.

1. k. 1-90v: „Pedagogika“.

2. k. 91-120: "Dydaktyka“.

3. k. 121-152v: "O wychowaniu intelektualnym".

4. k. 153-171v: "Wychowanie fizyczne".

84 Ur, $1817 \mathrm{w}$ Samborze, prof. UJ 1850, rektor 1872-1873, zm. 1896. - Es t.r. Ser. IV, I 390-392; A. K a r bow la k, Jw. s. LXII; Pol. Stown. bıogr. VI 436 (J. Gwrazdomorski). 
5. k. 172-237: „O wychowaniu moralnym“.

Skrypt jednego $\mathrm{z}$ galicyjiskich seminarı́w duchownych. Na k. 152v napis: „Skończyłem pisać dnıa 10/12 1898. A. Kanıa, moralısta“.

Proweniencja: 1. A. Kania.

2. Biblioteka OO. Kapucynów w Krakowie.

\section{JEZYKOZNAWSTWO}

150. Pol., starostow. $1877-1878.22 \times 17 \mathrm{~cm}$. K. 251. Opr. ptpt. wsp. „Porównawcza pierwoskładnia języka starosłowiańskiego i polskiego. $Z$ wykładu prof. dra L[ucjana] Malinowskiego ${ }^{85}$. Zebrał R[oman] Zawiliński ${ }^{86}$ st. fill."

Inc.: k. 2: „Powszechnie używany wyraz nie jest dosyé ścisły $\mathrm{X}$ analogicznie zaimek my w składni - mo.", k. 251.

Skrypt $\mathrm{z}$ wykładów uniwersyteckich. Na grzbiecie tytuł drukowany: „Malınowskı, Odczyty“.

Proweniencja: 1. Roman Zawiliński.

2. Biblióteka OO. Kapucynów. Kraków.

151. Niem., franc. $I$ pot. $X I X w .17 .5 \times 11.5 \mathrm{~cm}$. K. 71 . Opr. płsk. wsp.

Cwiczenia językowe.

Inc.: k. 2: „Au printemps de l'an 1813 un officier français $\mathrm{X}$ welchen Schein will kein Mensch bekommen?", k. 36v.

Blok rękopisu składa się z papıeru czerpanego siwego i zwykłego białego. Karty niezapisane: $1,18 \mathrm{v}, 37-58,62 \mathrm{v}-66 \mathrm{r}, 68-71$.

Składk1: 5. Ternion 1. Kwaternion 2. Seksternion 3. Septentrion 5. Składka 4 liczy $26 \mathrm{k}$.

Bez filıgranów.

Oprawa w tekturkę. Grzbiet i rogi obciagnnięte sk. cielęcą barwioną na brązowo. Okładkı obciągnięte papierem czerpanym nıebieskim $z$ nadrukiem drzeworytniczym czarnobialym. Szycie nleumiejętne na 3 sznurki. Brzegı nakrapiane na czerwono.

Proweniencja: Biblioteka OO. Kapucynów. Kraków.

\section{RETORYKA I POETYKA}

152. Eac., pol. II pot. XVII w. $19 \times 15.5 \mathrm{~cm} . K .113$. Opr. perg. wsp.

„Parnasus bicollis seu poesis bipartita duplici solutae et ligatae svadae ubertate in faecunda Gargara proximumque caelo asurgens gloriae Olympum. In patentem autem nobilis studiosae iuventutis Coll. Nossco-

85 Ur. 1839, prof. UJ 1877, autor licznych prac naukowych, 2m. 1898. - - Wielka enc. ilustr XLV/XLVI 316-318; Estr. Ser. IV, III 53; L. F1nkel, JW. Cz. 2 s. 2094 ;wykaz prac); G. Kor out: Literatura polska od początków do wojny światowej. Wyd. 2. T. 1-4. Warszawa 1929-1933. Dopeln1acz 1. T. 4. s. 41-42.

86 Ur. 1855, zm. 1932. Uczeń prof. Malinowskiego, pedagog, językoznawca, red. Poradnika językowego (1901-1931). - Enc. Gutenberga XVIII 266; E s $t$ r. Ser, IV, IV 599-600; L. Fin k e 1 , Jw. Cz. 2 s. 2144 (wykaz prac.). 
viani Pulto[viensis] Soc. Jesu. propositus a'scensum et usum. Anno quo libet ascensu nobis piget collam obtulit artis ubi binae pallas sua vigila".

Inc.: k. 3: "Quamvis ad poesim in rigore sumptam X recomendując zostaję WM Pana życzliwym bratem etc.", k. 113v.

Szkoła: Kolegium jezuitów w Pułtusku. Skryptor: prawdopodobnie ks. Kazimierz Weysse.

K. 86 oderwana. Na k. tytułowej napis: „Andreas Olęcki".

Składk1: 16. Biniony 11, 14. Terniony 15, 16 bez $1 \mathrm{k}$. Pozostałe kwaterniony lecz 1 i 13 bez $1 \mathrm{k}$.

Filigrany: tarcza herbowa $\mathrm{z}$ koroną $\mathrm{i}$ inicjałamı $\mathrm{M} \mathrm{O} \mathrm{H} \overline{\mathrm{l}}$ pośrodku, k. 60. Inicjaly $F L, k$. 21. Stylizowana litera $M$ na. k. 27. Orzeł na tylnej wyklejce.

Oprawa $w$ tekturę szarą obciągniętą $w$ caloścı pergamınem, na tylnej okładce częściowo sztukowanym. Na grzbiecie ślady malowanı farbą olejną. Szycie na 3 sznurki. Kapitałka szyta na płótnie szarym.

Proweniencja: 1 . Ks, Kazimierz Weylsse.

2. „Ex libris Adm. Rdi Dni Casimiri Weysse Canonici Klelcensis Paenitentiarii Cath. Craco[viensis] donatis et applicatis PP. Capucinorum Conventus Craco[viensis] pro cuius anima benigne lector dicat Ave Maria". Napis na k. 1v. Biblioteka OO. Kapucynów. Kraków. Pieczạtka okragłła na od’wrocie wyklejki frontowej i k. 113v. Sygn.: 28 D - 15; Nr XLVIII (o. Z. G.).

153. Eac., pol. $1713-1714.20 \times 15.5 \mathrm{~cm} . \mathrm{K} .190$. Opr. sk. wsp.

„Status regni eloquentiae a primate primoque oratorum principe Mercurio institutus triplici ratione divisus. Ad cuiusvis oratorii artefacti dispositionem compositus fundamentalibus in arte rhetorica statutis constans et futuris in regno statistis libero. Illustribus eloquentiae auditoribus per primarios ministros penes publicam omnium Palladis ordinum convocationem Varensi' in Palatino primi quondam Poloniarum statistae Matczynii conclavi explanatus. Anno quo Rex saeculorum collabsum Rei Publicae humanae statum erexit septingentesimo XIII et XIV supra millesimum".

Inc.: k. 4: „Rhetorica est ars ornate dicendi $\mathrm{X}$ saepius et ad praxim reducant", k. 190.

Szkoła: Kolegıum pijarów w Warężu. Skryptor: prawdopodobnıe Francıszek Michał Kielarsk1.

Reklamanty. Karty niezapisane: 2, 3v, 43, 194 (połowa k. wycıęta), 146v, $166 \mathrm{v}, 178 \mathrm{v}, 179$ (zachowana $1 / 3 \mathrm{k}$ od strony brzegu), 180, 190v. Slady po licznych wyceetych kartach. Nielıczne glosy interinarne. Tytuly poszczególnych rozdzıałów wykonane ręcznym pısmem w formie liter drukowanych. W rękopisie znajdują się nieliczne teksty polskıe. Kodeks ze śladami częściowego zawilgocenia.

Składk1: 53. Ternıon 19. Pozostałe binıony lecz z licznymi defektami.

Filigrany: orzel dwuglowy, k. 160, 190.

Oprawa w tekture sklejaną z czerpanego papieru. Cała sk. czarna silnie zniszczona. Na frontowej i tylnej okładce ślady lınii tłoczonych żelazkiem na clemno. Grzbiet zamalowany na popıelato z napisem: „Rhetorica“. Szycie na 2 sznurki. Kapıtałka szyta ręcznie. 
Proweniencja: 1. „Manu scripta Francisci Michaelis Kielarski". Napis na k. tytułowej.

2. Biblioteka OO. Kapucynów w Olesku. Pieczątka okrągiła na k. 3, 147, 184. Sygn.: IX 21.

3. Biblioteka OO. Kapucynów. Kraków. Pieczątka okrągła na k. 2v, 190v.

154. Eac. 1717. $21.5 \times 17 \mathrm{~cm}$. K. 118. Opr. brosz. wsp.

„Clypeus saptientis animi..."

Inc. k. 1: „Initer magna et praeclara quae a prima $\mathrm{X}$ in laudem demortui et consolationem amicorum", k. 118.

Szkoła: Kolegium Nowodworskiego w Krakowıe. Profesor: Maciej Stanisław Federowicz ${ }^{87}$. Skryptor: Antoni Krząnowsk1.

Reklamanty. Oryginalna lecz błędna foliacja od k. 108. Po k. 109 następuje bowıem k. 200 a należało wypısać k. 110. Glosy marginalne. Tytuły i podtytuły wykonane ręcznym pismem w formie liter drukowanych. Kursywa duża 1 wyraźna bez skrótów. Kolofon na k. 118v: ,Tradita haec rhetorica auxilıante Deo a Clarıssimo ac Excellentissimo Domino Dno M. Mathia Federowicz Scholae Rhetorices dignissimo professore... Scripta vero per me Antonıum Krząnowski eiusdem etram scholae alumnum commutatione hyemalı. Anno Dommi... 1717 de vero 25 aprilis...".

Składkı: 11. Ternion 11. Kwaterniony 1, 3. Kwinternion 10. 4 ma $24 \mathrm{k}$. Pozostałe seksterniony.

Filigrany: $w$ dwóch skrzyżowanych gałęziach tarcza herbowa uwieńczona koroną, w polu jeleń w skoku, k. 26, 31. Litera I a pod nıą stylizowane W, k. 4, 5. W polu tarczy herbowej półorzeł, k. 46, 47. Inicjały L M, k. 70.

Oprawa w tekturkę ze sklejanej makulatury druku, obcıąnięta w papıer czerpany karagenowy o motywie grzebieniowym. Szycie na 2 sznurki.

Proweniencja: 1. Ks. Antoni Krząnowski.

2. Biblioteka OO. Kapucynów. Kraków. Sygn. $\mathrm{Nr}$ LV (o. Z. G.).

155. Eac. 1717. $20.5 \times 16 \mathrm{~cm} . K .79$. Opr. płsk. wsp.

„Robur infractum quaevis frangens fortissima eloquentia. In cuius doctrinam ab eloquentissimo viro Simone Caulerio traditam istit..."

Inc.: $k .1 v$ : „Per naturam intelligitur definitio. Definitio est X Vitunus deus vitae, Vacuna dea ottiosorum", k. $79 \mathrm{v}$.

Szkoła: Kolegium Nowodworskiego w Krakowie. Profesor: Maciej Stanisław Federowicz. Skryptor: Antonı Krząnowskı. Kolofon na k. 79: „Haec rhetorica favente Deo Simonis Caulerii v1ri excellentıssiml, tradita est a Clarissimo ac Excellentissimo Domino Dno Mathia Federowicz Scholae Rhetorices dignıssimo professore. Scrıpta vero per me Antonium Krząnowski elusdem scholae alumnum. Finita die 20 octobris vero ann Dnı $1717^{\prime \prime}$. Bez karty tytułowej.

Składki: 10. Biniony 1-4. Kwaterniony 5, 6. Kwinternion 10 bez $3 \mathrm{k}$. Seksterniony 7, 8, 9.

87 H. B a y c z, Jw. s. 203 nr 70; Es tr. XVI 133-185; J o c h e r nr 1498; Wł. W i s ł o c k I, Jw. nr 3959; H. B a ry c z : Historıa Szkól Nowodworskıch od załozenia do reformy H. Kolłątaja (1588-1777). Kraków 1939-1947 s. 184. 
Filıgrany: myślıwy na konıu dmący w róg, wyklejka frontowa. W skrzyżowanych gałęzıach tarcza herbowa $\mathrm{z}$ jeleniem $\mathrm{w}$ skoku, $\mathrm{k}$. 2, 3. Inicjały w linii pionowej I W, k. 66, 67.

Oprawa w tekturkę. Grzbıet 1 rogı obciągnięte sk. brązową, okładkı papierem czerpanym, marmurkowym grzebieniowym na karagenie. Brzegi nakrapiane $\mathrm{w}$ pasy czerwone i niebieskie.

Proweniencja: 1. Ks. Antoni Krząnowski.

2. Biblioteka OO. Kapucynów. Kraków. Sygn.: Nr LI (o.Z.G.).

156. Eac., pol. 1718-1719. $19 \times 15.5 \mathrm{~cm}$. K. 82. Opr. płsk. wsp.

1. k. $1-25 \mathrm{v}$. „Igniculi oratorii intra saevientes brumae algores rhetorum animos ad gratulatorios affectus accendentes seu doctrina de gratulatoriis impetibus breviter proposita".

Inc.: k. 2: „Est oratio affectuum vel laetitiam gratulantis X Finivi vero anno Dni 1719 die 24 aprilis", k. 25v.

2. k. 27-66. „Computus sarmaticus non Poli ast Poloniae planetarum motus, non epacta, sed virorum acta, non aureum numerum horarum sed heroum ferreum syllabum novilunia et plenilunia syderum gentilitiorum demonstrans. Nobillissimae iuventuti rhetorico academicae ad complementum oratorii numeri extraditus. Anno... 1718 die 28 8bris".

Inc.: k. 28v: ,Est symbolum ac signum virtutum politicarum $\mathrm{X}$ professorem Scholave Rhetorices vigilantissimum. Finitus anno Dni 1719 die 27 aprilis", k. 66.

3. k. 67-82v: „Arra lampadibus lumine fidei et doctrinae catechisticae plenis adornata seu doctrina de sacrosancto missae sacrificio iuventuti academico-philosophicale pro commutatione hyemali expostita anno Domini 1718 die".

Inc.: k. 68: „Est oblatio rei sensibilis soli Deo $\mathrm{X}$ picta vero per me Antonium Krzanowski eiusdem scholae alumnum“, k. 82.

Treść: pierwsza część zawiera formuły życzeń z okazji śwıąt, imıenin itd., tak w języku łacińskım jak 1 polskim. Druga opisuje polskıe herby 1 podaje życzenıa dla szlachty. W trzeciej znajduje sıę objaśnienie mszy św.

Szkoła: Kolegium Nowodworskıego w Krakowie. Profesor: Idzi Stefan Wadowski ${ }^{88}$. Skryptor: Antoni Krząnowski. Rękopis autoryzowany: „Diligentiam discipulı approbans laudo et in fidem manum appono. M. Aegidius Wadowskı Ph. D. et Rh. Pr. operıs author indignus mp.", k. 82v.

Karty niezapisane: 1v, 26, 66v, 67v. Nad pierwszym tytułem znajduje sıę ozdobny krzyżyk. Wstęp do pierwszej l drugıej części okolony floraturą.

Składkı: 21. $7 \mathrm{ma} 2 \mathrm{k}$. Pozostale biniony.

Filigrany: w dwóch skrzyżowanych gałęziach tarcza herbowa z jeleniem w skoku, k. 66, 67. Inicjał I V, k. 64.

s8 Zm. 30 I 1721. - Mortuologium s. 422; Historıa Conventus nostri Capucinorum Cracoviensium. Rkps AKK. T. 1 s. 40 : ,summe fuit nobis addictus, reliquitque omnes suos libros per testamentum pro nostra bibliotheca... relicta est etiam conventu nostro elus effigles"; Es tr. XXXII 140-142 (datę śmiercı podaje na 31 I, inaczej niż Mortuologıum i Historia, JW.); J o c h e r nr 5409, 5412 . 
Oprawa w tekturkę. Grzbiet obciągnięty wąską sk. brązową a okładki papierem czerpanym, grzebieniowym marmurkowym na karagenie. Szycie na 2 paski pergaminowe. Brzegi kolorowane pasami czerwononiebieskımi.

Proweniencja: 1. "Ex libris M. Antoni Krząnowskkj S. Th. D. Clepardliensis S. Floriani Prepositi.". Napis na $k$. tytułowej.

2. Birblibteka OO. Kapucynów. Kraków. Sygn.: Nr XXX (o. Z. G.).

157. Eac., pol. $1719-1768.18 .5 \times 15 \mathrm{~cm}$. K. 80. Opr. sk. wsp.

Orationes variae.

Inc.: k. 2: „Parcite incapaci mundo A. A. quod millenis annorum $X$ quod in navi hac ut transilias ad honorem", k. $80 \mathrm{v}$.

Treść:

1. k. 1-6. „Universitatis felicitatıs litterae seu oratio in laudem litterarum ad innovationem studiorum in classibus Novodvorscianis praesente hospitum corona ab Illustrissimo Magnif. D. Vladislao Szołdrski Vexilliferrida Posn[aniensi] commutatione aestiva dicta".

2. k. 6v-7v. ,Salutatio Illustrissimi ac Excellentissimi Domini Domin Ioannis a Słupow Szembek Regni Poloniarum Cancellarii Magni Universitatis Cracovien[sis] protectoris maximi dicta ab Illustrissimo ac Magnifico Dommo Stephano Szołdrski Vexilli[ferridal Posnaniensi. Anno D. 1719 die 21 maii".

3. k. $7 \mathrm{v}-8 \mathrm{v}$. "Salutatio eiusdem Illustrıssımi a Magnifico Domino D. Stanislao Kostka Dembiński Venatorida Craco[viensi] dictá".

4. k. 9-16. „Rosa innocenti sanguine purpurata spinis gladiorum armata. D. Stanıslaus Antistes Cracoviensis, Regni Poloniae Patronus seu oratio in laudem ipsius elaborata".

5. k. 16-16v. „Gratulatio festi Sancti Joannis Illu[strissimol Cancellarıo Regni expedita per Illustrem ac IMagni[ficum] Dominum Stanislaum de Bnin Opaliński".

6. k. 17-20v. „Praedicabile seu vox apta nata praedicari de X[ris]to. D. Joannes Baptista praecursor D[omi]ni olim inter frondes deseni nunc in arbore Porphyrii observatum et ab academicis dialecticis optime rhetorica in sua nativitate proclamatum".

7. k. 21-24. „Substantia accidentibus necessitatis mortalium coram Deo substans in arbore vitae observata. B. Neonata V. Maria seu oratio in laudem ipsius composita".

8. k. 26-31v. ,Angulus virtute et sapientiae plenus, sarmaticam fortunam conservans. D. Joannes Cantius Universitatis Cracov[iensis] Patriarcha et Doctor Regni Poloniae Patronus seu oratio in laudem ipsius ab academicis dialecticis composita".

9. k. 32-32v. „Salutatio Perillustris Clarissimi et Admodum Reverendi Domini Scholarum Novodvorscianarum provisoris, autumnalium laurearum distributoris".

10. k. 32v-33. „Gratulatio rectoralis honoris Magnifico Perillustri Clarissimo et Addum Rdo Dno D. Universitatis Cracoviensis G[ene]rali Rectori nomine professorum classisticorum".

11. k. 33-33v. "Gratulatio eiusdem honoris nomine iuventutis dialecticae".

12. k. 33v-34. „Gratulatio festi patroni Perillustri Claris. et Addum Rdo D. Scholar[um] Novodvor[scianarum] provisori nomine professorum dicta". 
13. k. 34. "Gratulatio".

14. k. $34 \mathrm{v}-38 \mathrm{v}$. "Argumentum optimum universalem laetitiam ex Mariano Ave miseris mortalibus concludens nunc a dialecticis reasumptum Adventus Christi Domini seu oratio generis demonstrativi tempus hoc maioris devotionis causa recommendans".

15. k. 39-45. „Doctor artium liberantium caelestis captivam adhuc et in calamitate gementem Poloniam modum liberandi edocturus. D. Joannes de Matha seu oratio in laudem ipsius ab academicis dialecticis composita".

16. k. 45-46. „Forma gratulatoria honoris redundantis ex patribus in filios Illustribus Magnificis Dominis D. Stephano et Vladislao Szoldrski Castellanidis Gnesnensibus, dialectices auditoribus dedicata".

17. k. 46-48v. "Candor intaminatae vitae in regia purpura niveus seu oratio in laudem D. Casimiri Regni Poloniarum principis et patroni. Recurrente annua eiusdem solemnitate rostris, Mariani Oratorii ab academicis dialecticis applicata“.

18. k. $48 \mathrm{v}-49$. „Gratulatio honoris senatorii Illustrissimo et Excellentissimo Domino D. Francisco Wielopolski Comiti in Zywiec et Pieskowa Skała Palatino Siradiensi, Minoris Poloniae Generali, Cracoviensi, Lanckoronensi, Żarnowecensi etc. etc. Capitaneo".

19. k. $49 \mathrm{v}-51 \mathrm{v}$. „Impetus gratulatorii Paschatis“.

20. k. 52-53. „Sigillum laboris sepulchrali Resurgentis Domini adiunctum seu elogiare votum laborem hyemalem Resurgenti Xristo Domino consecrans“.

Od k. 53v-56v. Mowy Antoniego Krząnowskiego w r. 1720 w Akademii Krakowskiej miane przy okazji otrzymywania stopni naukowych. Spis wykładów z r. 1742, k. 63v. „Notata varıa curıosa et necessarıa“. k. 64-76v. Wykaz fundatorów różnych zakonów, k. 77-77v. Fragmenty mów i kazań, k. $79 \mathrm{v}-80 \mathrm{v}$.

Kodeks zawiera mowy wygłoszone w szkole Nowodworskiego w Krakowie i w Akademii Krakowskıej. Autorem rękopisu jest Antonı Krząnowski. Tytuły poszczególnych mów umieszczone w ozdobnych podwójnych ramkach marginalnych. Karty niezapisane: $1 \mathrm{v}, 17 \mathrm{v}, 21 \mathrm{v}, 24 \mathrm{v}, 25,26 \mathrm{v}, 39 \mathrm{v}, 57 \mathrm{v}-63 \mathrm{r}$, $78 \mathrm{v}, 79 \mathrm{r}$. $\mathrm{Na}$ marginesach numery paragrafów. Glosy marginalne bardzo liczne. Inskrypcja na k. 53: „Traditi hi libri a Claris. ac Excell. D. M. Aegıdio Stephano Wadowski philosophiae doct. et prof. Scholae Dialectices ordinario professore compactı per me Antonium Krzạnowski elusdem alumnum". Wstawka luźna zawierająca pısmo dziekana Wydzıału Teologıcznego UJ z r. 1768 . $\mathrm{Na}$ frontowej wyklejce przylepiona wklejka: "Notata de aquis" oraz następująca informacja: "Thesaurus inventus est in Academıae Cracoviensis muro, Lectorio Socratis a. D. 1494 die 27 iunii, festo S. Ladislai, 1deoque hic dies est illegibilis. Summa aureorum 250 et tantumdem in annulis unionibus et gemmis. Summa vero florenorum polonicalium 902".

Składki: 11. Binion 1. Ternion 9. Pozostałe kwaterniony lecz 2 bez $1 \mathrm{k}$., 11 bez $2 \mathrm{k}$.

Filigrany nie zidentyfikowane.

Oprawa w tekturkę, obciągniętą w całości sk. cielęcą barwioną na brązowo i nakrapianą czarną farbą. Grzbiet gładki. Na grzbiecie linie proste tłoczone na ciemno. Na okładce ramka wytłoczona linıą czarną wokół na ciemno. Slady rzemyków do wiązania. Szycie na 2 paski pergaminowe. 
Proweniencja: 1. "Ex libris ME. Antoni Krząnowski S. Th. D. Clepardiensis S. Floriani Prepositi". Napis na k. 2.

2. Biblioteka OO. Kapucynów. Kraków. Sygn.: Nr LXXXIII (o. Z. G.).

158. Eac., pol. 1721-1722. $19 \times 15.5 \mathrm{~cm}$. K. 113. Bez opr.

Rhetorica.

Inc.: $\mathrm{k} .1$ : „1mo capita vel fontes ex quibus laudes $\mathrm{X}$ immutari vota castitatis religionis et Jerosolimitani““. k. 113v.

Treść:

1. k. 1-64. Retoryka.

2. k. 65-81. „Lux poetica sive poesis symbolica. Continens symbola tam discursibus quam orationibus servientia, poetis simulque oratoribus necessarıa. In Academıa Olıcensi nobilibus humanıtatıs alumnis illustrata. Anno... 1722 die 24 lunii".

3. k. 82-113. „De fide et symbolo fidei“. idonea".

4. k. 88. „Instructio spendiosa ad sacros ordines suscipiendos aspiraturo

5. k. 93v. "De sacramentis".

6. k. 100. Poetyka.

7. k. 102. O sakramentach.

8. k. 104. Retoryka.

9. k. 105v. „Doctrina brevis de censurıs".

10. k. 111v. "De vita spirituali".

Szkoła: Akademı w Olyce. Kodeks bez początku i końca. Liczne kartki wyrwano z bloku rękopisu. Pismo kilku rąk. K. 100 przez pomylkę podwójnie foliowana. Winietka ozdobna na k. 14.

Składki: 13,3 ma $2 \mathrm{k}$. Binion 2. Kwaterniony 1, 4-7, 8-12 lecz 12 bez $1 \mathrm{k}$. Septentrion 13 bez $1 \mathrm{k}$.

Filigrany: myślıwy na koniu, dmący w róg, k. 3, 6. W tarczy herbowej krzyż równoramienny, k. 10, 11. Baran, k. 25, 28. Orzeł dwugłowy z koroną, k. 76 .

$\mathrm{Z}$ dawnej oprawy pozostało szycie na 3 sznurkı.

Proweniencja: 1. „Ad usum Magnifici ac generosi Domini Casumiri Dominici Leżbicki (?) anno Dni" 1741 die 1ma septembris". K. 14.

2. Biblioteka OO. Kapucynów w Krakowie. Sygn.: 3 G -22.

159. Łac., pol. 1729-1731. $19.5 \times 15.5 \mathrm{~cm}$. K. 557. Opr. sk. wsp.

1. k. 1-22. „Universale ad scholastica celebranda comitia ratione libertatis patriae oratorio stylo tuendae editum. Et ad illa tractanda praeceptis rhetoricae instruens. Tempore generalium comitiorum Grodnae celebratorum atque Illustres et nobiles eloquentiae cultores ad id exequendum in Collegio Lucoviensi Sicholarum Piarum adhortans. Anno... 1730 in 1731 annum".

Inc.: k. 2: „Princeps scientiarum rhetorica hoc integro cursu $\mathrm{X}$ geminat ubertatem. Modi tractandae similitudinis", k. 22.

2. k. 23-557. „Trabea triumphatricis animorum eloquentiae inter annui laboris ferias, studio et opere oratorio contexta. In maiorem 
praelii valorem praeceptorum dogmatis, praxium in utroque stylo claritatem nitida. Selectae eruditionis compendio adornata eiusdem reginae artium candidatis. In Collegio Jeziorsciano Lucoviensi Scholarum Piarum oblata. Anno... 1729 in annum 1730 die 14“.

Inc.: k. 24: „Universam rerum creatarum molem, naturam X przyświca, przyświeca światu całemu pogoda“, k. $557 \mathrm{v}$.

Treść: mowy i poezje.

Szkoła: Kolegium pijarów w Eukowıe. Reklamanty. Karty niezapisane: 1v, $22 \mathrm{v}, 23 \mathrm{v}, 36 \mathrm{v}, 60 \mathrm{v}, 64,102,156-158 \mathrm{r}, 154 \mathrm{v}, 188 \mathrm{v}, 231,232,239 \mathrm{v}, 240,249 \mathrm{v}$, $288 \mathrm{v}, 289,323 \mathrm{v}, 349-351,373,386 \mathrm{v}, 401 \mathrm{v}, 415 \mathrm{v}-417,433,451 \mathrm{v}, 453,462 \mathrm{v}-465$, $482,483,496,497,521,557 v$. Karty wydarte: po k. 188, po k. 253 jedna składka, po k. 476 około trzy składki, po k. $4782 \mathrm{k}$.

Składki: około 60 kwaternionów.

Filigrany: tarcza herbowa z krzyżem równoramiennym, k. 145, 386, 415. Napıs: BZO, k. 483. Jeźdzıec dmący w róg, na koniu, obok z lewej strony wysoki krzyż, k. 521, 557.

Oprawa w tekture szarą i calą sk. cielęcą barwioną na brązowo. Grzbiet zamalowany w całości farbą popielatą z wymalowanym tytułem: „Fundamenta rhetorica". Ramka odciśnıęta lınıą grubą na okładce frontowej i tylnej. Szycie na 4 wıęzy. Kapitałka szyta ręcznıe.

Proweniencja: 1. Bibliotelka OO. Kapucynów w Olesku. Pieczątka okrągła na k. $1,273 \mathrm{v}, 440$.

2. Biblioteka OO. Kapucynów. Kraków. Pieczątka okrągła. na wyklejce frontowej i k. $557 \mathrm{v}$.

160. Eac., pol. 1739-1740. $19.5 \times 16.5 \mathrm{~cm}$. K. 149. Opr. psk. wsp.

1. k. $1-54 \mathrm{v}$. "Directrix Apollinae Reipublicae poesis suos neovates ad decurrendum anni spacium periodicis et versuum pedibus manuducens. Prompto animo et penna in Athenaeo Słonimensi Societatis Jesu proposita a. Dni 1739 in 1740 ".

Inc.: $\mathrm{k} .2 \mathrm{v}$ : ,Poesis minus rigorose sumpta est $\mathrm{X}$ semper sit sensus perfectus et nitidus", k. 54 .

2. k. 58-147 „Phrases seu modi loquendi cultiores at quamvis amplificationem maxime idoneae dabunt uberrimam ornatae dicendi materiam eruntque velut gemmae super umbonem distinctae si illas diligens at studiosa imitatio in usum cultioris svade secernere et prudens aestimatio incliti humanitatis tyronis sciet appreciare".

Inc.: k. 59: „A teneris generosus tyrotinia aetatis suae posuit $\mathrm{X}$ slawie, parem non protulit aetas", k. 136v.

Szkoła: Kolegium jezuitów w Słonimie. Profesor: prawdopodobnie o. Paweł Zubowski ${ }^{89}$.

Reklamanty. Karty niezapisane: 1v, 55, 56, 57, 58v, 147v, 148, 149. Słownik polsko-łacıński, k. 144-147.

99 Prof. retoryki 1 poetyk1 w Stonmmie w 1. 1740-1741. - Cat. Prov Poloniae et Lithuaniae a. 1740 in a. 1741; ArSI, Lith. 58 f. 9. 
Składki: 23. Biniony 1-14, 22. Kwaterniony 19, 23 bez $1 \mathrm{k}$. Kwinternion 20. Seksterniony $15,16,18,21$. Okternion 17.

Filıgrany: tarcza herbowa z krzyżykıem u góry, k. 55, 56.

Oprawa w tekturę. Grzbiet i rogi obciągnięte $w$ sk. cielęcą barwiona na brązowo. Okładki obciągnięte papierem czerpanym nakrapianym niebıeską farbą. Szycie na 3 więzy. Brzegi niebieskie.

Proweniencja: Biblioteka OO. Kapucynów. Kraków. Pieczątka okrągła na k. 1v, 147. Sygn.: $29 \mathrm{E}-31$; $\mathrm{Nr}$ XLVI (O. Z. G.).

161. Eac., pol. II pot. XVIII w. $19.5 \times 15.5 \mathrm{~cm}$. K. 67. Bez opr.

Exercitia polonica et latina.

Inc.: k. 1: „Nemo unquam magnus sine afflatu divino fuit $\mathrm{X}$ principio tali, sic benie cedit opus", k. $67 \mathrm{v}$.

Zeszyt szkolny z ćwiczenıamı polskımi i łacińskimi. Bez karty tytułowej. Karta początkowa 1 końcowa w strzępach. Po $33 \mathrm{k}$. wycięta składka. Karta niezapisana: 1v. Glosy marginalne.

Składkı: 12. Binıony 1 i 2 bez 1 k., 3, 4 i $12+1$ k. Ternıon 5 . Kwaterniony 7 wyciety, 8 bez $3 \mathrm{k} .9,10,11$. Kwinternion 6 bez $1 \mathrm{k}$.

$\mathrm{Z}$ oprawy pozostało szycie na 3 sznurki.

Proweniencja: 1. Franciszek Kło...., ik. 67v.

2. Biblioteka OO. Kapucynów w Krakowie. Sygn.: LXXXII (o. Z. G.).

162. Pol. I pot. XIX w. $32 \times 18 \mathrm{~cm}$. K. 198. Bez opr.

"O wymowie przez Adama Dorożýskiego".

Zbiór skryptów z zakresu wymowy, używanych w szkołach.

Składki: 38 binionów.

Proweniencja: 1. Adam Dorożyński. $1815 \mathrm{r}$.

2. Bibliateka OO. Kapucynów w Krakowie.

\section{LITERATURA PIEZKNA}

163. Łac. 1681. $15.5 \times 9 \mathrm{~cm}$. K. 81. Bez opr.

1. k. 1-51v. „Cafres. Tragoedia. Auctore P. Jo[anne] Bap[tista] Giattino ${ }^{89 a}$ Panorm [itano] S. J. 5 hablita in Seminar[io] Rom[ano] 1651. Romae Typis Haeredum Corbeletti 1651. Superiorum permissu“".

Inc.: k. 6: „Sebastianus Cafrum imperator christianam fidem $\mathrm{X}$ suppeditat, Cereri quercus famulatur ad aram", k. $51 \mathrm{v}$.

2. k. 52-80v. Antigonus tragoedia moralis. Auth[ore] J. Jo[anne] Bapt[ista] Giattino S. J. 1661".

Inc.: k. 52: "Argumentum fabulae fundatum est in historia $\mathrm{X}$ sacra et profana gaudia, et plausus sonent: k. 79 .

Kodeks przepısany z druku w Krośnie w r. 1681 przez jednego z jezuitów. $\mathrm{Na} \mathrm{k.} \mathrm{4,} \mathrm{5,78,} \mathrm{79v} \mathrm{objaśnıenıa} \mathrm{i} \mathrm{nazwy} \mathrm{krajów} \mathrm{oraz} \mathrm{wykaz} \mathrm{postaci} \mathrm{hısto-}$

${ }^{83}$ a Ur. 1601 w Palermo, do zak. Wstąpił 1615, zm. 19 XI 1672 w Rzymıe. - B a ckerSommervoge 1 III 1394-1400. Rękopıs przepisany z następujących druków: Nr 22. Cafres, tragoedia. Auctore P. Jo. Baptista Giattino Panormitano S. J. Quinquies habita in Semınarıo Romano. Anno Dominı MDCLI. Rorrate, typis haeredum Corbelletti, 1651, 80, pp. 109; Nr 37 - Antigonus. Tragoedia moralis habita un Colleg1o Romano Societ. Jesu ludis Minervalibus ad praemiorum distributionem. Romae, typ. H. H. Corbelletti, 1661, 80, pp. 80. 
rycznych. Glosy marginalne. Na k. 6v. inskrypcja: „Cros[nae] 168116 martii perfecti 19 eiusdem". Blok rękopisu ze śladami dawnego zawilgocenia.

Składk1: 5. 1 ma $18 \mathrm{k}$. Sekstemion 5, Okterniony 2, 3, 4.

Filigrany: fragment niezidentyfikowanego filigranu w lewym rogu karty. Inicjały: S H, k. 51, 60 .

$\mathrm{Z}$ oprawy pozostało szycie na 3 sznurki.

Proweniencja: Biblioteka OO. Kapucynów w Krakowie. Pieczątka owalna na k. 3, 51v, 52. Pieczątka okrągła na k. 3v, 51v, 80v. Sygn:: 29 B $-72 ; 0-190$.

164. Eac. 1700. $14.5 \times 10 \mathrm{~cm}$. K. 147. Opr. pzsk. wsp.

„Gemmae sententiarum sanctorum patrum tum illustrium virorum“. Dodatek inną ręlką: "Annotatae tempore novitiatus anno Dni 1700“.

Inc.: k. 2v: „Jeiunium ad alimentum est. S. Ambrosius X zelum temperare misericordlia. Idem", k. 146v.

Rękopıs zawıera złote myśli w układzie rzeczowo-alfabetycznym. Powstał on $w$ nowicjacıe kapucyńskım w Warszawie lub w Krakowie. Karty niezapisane: $1,20-25,27 \mathrm{v}-29 \mathrm{v}, 34,48 \mathrm{v}, 49,55 \mathrm{v}-59 \mathrm{v}, 64 \mathrm{v}-68 \mathrm{v}, 70 \mathrm{v}, 74,84,91 \mathrm{v}$, $101-102,116 \mathrm{v}-117 \mathrm{v}, 121-123 \mathrm{r}, 132 \mathrm{v}-137 \mathrm{v}, 146 \mathrm{r}, 147 \mathrm{r}$. Odwrocie k. 147 zawiera modlitwę do św. Stanisława.

Składkl: 10. Kwaternion $1.2-20 \mathrm{k}$., 3-16 k., ternion 4 bez $2 \mathrm{k}$., $5-20 \mathrm{k}$., 6-22 k., 7-22 k., seksternion 8, 9-17 k., 10-24 k.

Filigrany: fragment orła w lewym górnym rogu karty, k. 20, 84.

Oprawa w tekture sklejaną. Sk. czarna kozłowa. Grzbiet zamalowany farba popielatą. Okładkı obcıągnięte papierem czerpanym, klajstrowym. Szycie na 2 sznurki. Brzegı zielone.

Proweniencja: 1. Biblioteka OO. Kapucynów w Olesku. Pieczątka okraggła na k. 2.

2. Biblioteka OO. Kapucynów. Kraków.

165. Pol. 1809. $22.5 \times 17.5 \mathrm{~cm}$. K. 42. Opr. pzsk. wsp.

„Don Juan. Tragi-komedia w 3ch aktach“. (Tytuł okładkowy).

„Don Juan czyli ukarany libertyn. Tragi-komedia w 3ch aktach, z niemieckiego tłumaczona“. (Tytuł nagłówkowy).

Inc.: k. 2: „Juan. Powiadam ci Pedrylo, nie jątrz gniewu mego $\mathrm{X}$ bo to czart wszystko karbuje i w rejestrzyk swój notuje“, k. 42v.

Sztuka sceniczna nieznanego autora. Prawdopodobnie była wystawiana w jakımś amatorskim, może dworskım, teatrzyku. Blok rękopisu składa się z papıeru czerpanego siwego 1 białego. Glosy unterlinearne pochodzą od innej rękı. Liczne poprawkı, uzupełnienıa i przekreślenia. Znakı ołówkıem czerwonym lub zwykłym. Bardzo zniszczony, zapewne przez używanie. Na końcu tekstu inskrypcja: "Wolno reprezentowana z Galicji (?) 16 czerwca 1809". Podpis nieczytelny.

Składki: 12. 4, 6, 12 mają po $2 \mathrm{k}$. Pozostałe binıony.

Filigrany: data 1803, k. 6. Napis: Mhiot k. 14. Korona z krzyżykiem i floraturą, k. 22, 23. Fragment tarczy herbowej, k. 30, 31.

Oprawa w tekturkę. Grzbiet wąski i rogi obciągnięte skórką kolorowaną na brązowo. Okładki obciągnięte papierem czerpanym, naturalnym z naklejką 1 wypisanym tytułem na froncie. Oprawa zniszczona.

Proweniencja: Biblioteka OO. Kapucynów. Kraków. 
166. Pol. I pot. XIX w. $29.5 \times 25 \mathrm{~cm}$. S. 7, 67. Bez opr.

1. s. $1-7$. ,Na hersztów targowickich".

Inc.: s. 1: „Jakże! Kiedy z pogandą i wstydu i prawa X i gdzie nad ludźmi pycha kilku nieprzewodzi", s. 7.

2. s. 1-59. Poezje historyczne.

Inc.: s. 1: „Powstancie bracia $\mathrm{z}$ crichych grobów łona $\mathrm{X} w$ samym poranku dni męstwa i chwały, Ojczyzny uniósł nadzieje“", s. 59.

Druga część zawiera następujące utwory: „Cześć kmiotkom polskim za wolność poległym“, „Juliusz Małachowski“, „Rejtan“, „Kilinski“”, „Zal wieszcza nad grobem Tadeusza Koścluszki“", „Mokronowski“, „Madalınski“, „Głowacki“, „Sowiński“, „Wodzıcki“, „Włodzımierz Potocki“. Strony niezapisane: 6, 30, 31, $32,60-67$.

Proweniencja: Biblioteka OO. Kapucynów. Kraków.

167. Pol. I pot. XIX w. $17.5 \times 11.5 \mathrm{~cm}$. K. 33. Bez opr.

Wiersze.

Inc.: k. 1: „Ona rozpaczą napawa, sprawuje uszczęśliwienie $\mathrm{X}$ jeżeli wprzód nie zginę. To znaczy żelazo. Koniec", k. 32.

Zbıór poezji, opowiadań (k. 30-32) i „reguły czyli sposób robienia włosiennych prerzcionków" (k. 32v-33v).

Filigrany: fragment niezıdentyfikowanego filıgranu w górnej lewej części karty.

Proweniencja: Biblioteka OO. Kapucynów. Kraków.

168. Franc., pol. I pot. XIX w. $18.5 \times 11.5 \mathrm{~cm} . K .111$. Opr. sk. wsp. „Zbiór wierszy i pieśni różnych".

Inc.: k. 4: „Więc tę różę moje dziecię. Obraz twój $\mathrm{X}$ et d'amitié pour le personne qui nous oblige", k. $111 \mathrm{v}$.

Zbrór wierszy polskich, francuskich, oryginalnych i tłumaczonych, modlitw itd. należący prawdopodobnı do Kamili Kozıeradzkiej.

Składkı: 16. Ternion 1 bez $3 \mathrm{k}$. wyciętych. Pozostale kwaterniony ale 2 bez $2 \mathrm{k}$., 12 bez $3 \mathrm{k}$. wyc. 116 bez $7 \mathrm{k}$. wyc.

Filigrany: nazwısko: J Honig, k. 2, 3. Inıcjał G \&, k. 9.

Oprawa $\mathrm{w}$ tekturę brązową obcıągniętą sk. brązową zamszową. Brzeg gładki. Na frontowej okładce sk. silnie przepalona gorącym naczyniem. Szycie na 3 sznurkı. Brzegi złocone. Wyklejka z papıeru czerpanego z motywem zlelonych liści.

Proweniencja: 1. Kamila Kozieradzka Podpis na k. 1.

Biblioteka OO. Kapucynów. Kraków. Pieczątka owalna i akrągła na k. 1.

169. Pol. II pok. XIX w. $16 \times 11.5 \mathrm{~cm}$. K.: 121. Opr. płsk. wsp. ,Zbiór wierszy".

Inc.: k. 1: „Nam strzelać nie kazano - wstąpiłem X będzie wielka, potężna po wiekii wieków“, k. 121.

Wybór poezji współczesnych autorów od r. 1831-1850. Karty niezapisane: $111 v, 119 v$. Pismo trzech rąk. 
Filigrany: nazwisko: J W Hatman, 1840, k. 3, 10.

Oprawa w tekturkę, grzbiet obciągnięty czarną sk. chagrain 1 czarnym papıerem. Na froncie inıcjały: B. M. o rysunku gotyckım, tłoczone na ciemno. Kapitałka wklejana. Brzegı nakrapıane na czerwono.

Proweniencja: Biblioteka OO. Kapucynów. Kraków.

\section{MEDYCYNA}

170. Łac., pol., niem. II poł. XVIII w. $16 \times 10 \mathrm{~cm}$. K. 60. Opr. perg. wsp.

"Scholae artium curiosarum in natura deprehensarum".

Inc.: $\mathrm{k}$. 1: „Albumen ovorum commisceantur bene et in $\mathrm{X}$ multum sedat acetum ad inflammationem", k. $48 \mathrm{v}$.

„Catalogus specierum apothecarum", k. 52-54v. Fragmenty kazań, wplecione na k. 27v-29, 30, 31r, 33-34v. Karty niezapisane: $8 \mathrm{v}, 9,18 \mathrm{v}, 42,47 \mathrm{v}$, $49-51,55-56,57 \mathrm{v}-60$. „Index rerum", k. 57.

Składki: 6. Kwaterniony 3 bez 1 k., 4, 5, 6 bez $1 \mathrm{k}$. Septentriony 1, 2+1 k.

Filigrany: fragment filıgranu w górnej lewej częścı karty - skrzyżowane gałęzie z koroną, k. 49.

Oprawa $\mathrm{w}$ tekturke obciagnięta pergaminem $\mathrm{z}$ rękopisu średnıwiecznego. Szycie na 2 sznurki.

Proweniencja: Bibliotelka OO. Kapucynów. Kraków. Pieczątka owalna na odwrocie wyklejki frontowej. Sygn.: 30 B -47 .

\section{RĘKOPISY BIBLIOTEKI KLASZTORU W KROS̃NIE}

\section{'TEOLOGIA DOGMATYCZNA}

K 1. Eac. $1769-1772.19 \times 15.5 \mathrm{~cm}$. K. 328. Opr. ptsk. wsp.

1. k. $1-35 \mathrm{v}$. "Institutionum polemicarum dissertatio $1 \mathrm{ma}$ de gratia. Caput 1 mum de motione, divisione, sufficientia, efficatia et necessitate gratiae articulus 1mus“. Dopisek inną ręką: „Opera Rndi Patris Casimiri Grabiński 7bri 1769".

Inc.: k. 1v: „Quid et quotuplex sit gratia $\mathrm{X}$ ex fide et gratiae auxilii factos. Finis huius dissert[ationis]", k. 35v.

2. k. 36-64v: "Institutionum polemicarum de sacramentis in genere et in specie de eucharistia caput 1mum. De sacnamentis in genere articulus 1mus. De sacramentis in statu legis tum naturae tum Scripturae Veteris $\S 1$ mus".

Inc.: k. 36v: "An in statu legis naturae fuerint sacramenta $X$ ad probationes in oppositum alluta's", k. 64v.

3. k. 65-155. „Institutionum polemicarum dissertatio $1 \mathrm{ma}$ de sacramentis poenitentiae, ordinis et matrimonii caput 1 mum. De sacnamento poenitentiae articulus 1mus. De essentia, institutione et partibus sacra- 
menti poenitentiae § 1mus. Proposita a 7bri 1770 a. Opera Rndi P. Casimiri Grabiński. Auditor illius Michael Konieczko".

Inc.: k. 65v: „An poenitentia in cessatione a vitiis $\mathrm{X}$ nova haeresi planius dilucidari oporteat", k. 155.

4. k. 161-245. ,Institutionum polemicarum dissertatio de fide caput $1 \mathrm{mum}$. De revelatione objecti fidei articulus 1 mus. De notione, divisione et obiecto fiidei $\S 1$ mus. Proposita a 7 bri a. Opera Rndi Patris Casimiri Grabiński“.

Inc.: k. 161v: „Quid et quotuplex sit fides $\mathrm{X}$ ecclesia et propterea omnibus placet", k. 245.

5. k. 249-296. „Institutionum polemicarum dissertatio de verbi divini incarnatione caput $1 \mathrm{mum}$. De incarnationis possibilitate, existentia, essentia, et modo quo illa facta est articulus 1mus. De incarnationis possibilitate § 1mus. Opera R. P. Casimiri Grabiński S. J. 1772. Auditor illius A. Michael Konieczko".

Inc.: k. 249v: "Quid nomine incarnationis veniat? $\mathrm{X}$ ubi in obliquo importet", k. 296.

6. k. 296-325v. "Institutionum polemicarum dissertatio de libero arbitrio, de divina circa hominem providentia generali ac speciali ac de ultimo eius speciali praedestinatione articulus 1mus. De libero hominis arbitrio $\S 1$ mus".

Inc.: k. 296v: „Quid stit libertas et quotuplex $\mathrm{X}$ elicit apostolicis dogmatibus adversarius approbatur", k. 325v.

Szkoła: Kolegium jezuitów w Krośnie. Prof.: o. Kazimierz Grabıński ${ }^{80}$. Skryptor: Antoni Michał Konleczko ${ }^{91}$.

Reklamanty. Karty niezapisane: $155 \mathrm{v}-160 \mathrm{v}, 245 \mathrm{v}-248 \mathrm{v}, 322,326-328 \mathrm{v}$. $\mathrm{Na}$ marginesach numery bieżące zagadnień teologicznych. Glosy marginalne na k. 58v, 59. Na grzbiecie tytuł wytłoczony (błędnie) na ślepo: „Instıtutionum Polonicar[um]" zamiast „Polemicarum".

Składkı: 40 kwaternionów. Kustosze literowe.

Filigrany: prawdopodobnie tarcza herbowa z kotwıcą ponad tarczą, k. 155. 159.

Oprawa w tekturę szarą. Grzbiet i rogi skórzane, barwione na brazowo. $\mathrm{Na}$ grzbiecie tytuł ręczny, koło wlęzów bordiurka tłoczona na ciemno. Szycie na 3 więzy. Kapıtałka szyta zıelonobiała. Brzegı czerwone.

Proweniencja: 1. A. M. Konieczko.

2. Biblioteka OO. Kapucynów. Krosno. Pieczątka owalna, k. 1, 27, 119, 162, 212, 242, 2є2, 316. Sygn.: $55-\mathrm{B}$.

K 2. Eac. $1772.20 .5 \times 16.5 \mathrm{~cm}$. K. 416. Opr. ptsk. wsp.

"Theologia speculativa sicripta a P. Valentino".

30 Ur. 4 1II 1732, do zak. Wstąpil 1749. W okresie kasaty zakonu przebywal W Krośnie. ArSI, Pol. 37 f. 66 nr 4; Cat. Prov Poloniae Minorıs S. J. a. 1773. Premisliae 1773 s. 7.

${ }_{91}$ W 1. 1799-1804 był proboszczem w Haczowie. Por. St. F y m a : Haczów wieś ongiśs Królewska (1350-1960). Kraków 1962 s. 138. 
Inc.: k. 1: „Nota: Quod ex logica constet $\mathrm{X}$ velle homines salvos fieri", k. 410v.

Treść: k. 1: „Dısputatio 1ma de qualitate et de obiectis physicae“; k. 45: „Disputatio de mutatione accidentali“; k. 108: „Disputatio proemialis de qualitate metaphysices et elus obiecto"; k. 124: "Tractatus 1mus ex libro primo Sententiarum de Deo uno"; k. 202v: „Tractatus IIdus. De Deo trino"; k. 232v: "Tractatus de admirabil Verbı Divini cum humanitate hypostatica unione seu de incarnatione"; k. 305: „De sacramentis in communi"; k. 324: „De sacramentis in particulari“; k. 374: „Tractatus de gratia, iustificatione et merito".

Kodeks powstał w jednej z kapucyńskich szkól filozoficzno-teologicznych w kraju. Skryptorem jest o. Walenty Wróblewski.

Reklamanty. Karty niezapisane: 43v, 44, 107v, 108r, 411-416. Na marginesach numery bieżących zagadnień. Dukt pisma lukowaty. $\mathrm{Na}$ pierwszych $113 \mathrm{k}$. daje się zauważyć częściowo obcięcle przez introlıgatora tekstu dolnej kolumny pisma.

Składkı: 45. Do 16 składki kwinterniony na przemian z ternıonami. Od 17 składkı kwaternıony na przemian z seksternionami.

Filigrany: Matka Boska z Dziecıątkiem w otoku promieni, k. 411, 413. Tarcza herbowa $\mathrm{z}$ koroną i inicjałami $\mathrm{C} \mathrm{R}$ u dołu, k. 107, 108.

Oprawa $\mathrm{w}$ tekturę szarą, szmacianą. Grzbiet oprawiony w sk. cielęcą, barwıona na brązowo. Okładka obłożona klajstrowym papierem czerpanym. Szycie na 3 wlęzy. Brzegi nakrapıane na niebiesko.

Proweniencja: 1. O. Walenty Wróblewsiki.

2. „Pro Bibliotheca Crosnensi PP. Capucinorum relinquit Fr. Romedius Capucinus 1772 anno". Napis na wyklejce frantowej.

3. Biblioteka OO. Kapucynów. Krosno. Pieczątka owalna, k. 1, 84, 150, 243, 291, 361. Sygn.: $15 ; 197 ; 25-$ F.

\section{TEOLOGIA MORALINA}

K 3. 1742-1744. $21.5 \times 18 \mathrm{~cm}, K .403$. Opr. ptsk. wsp.

„Pars prima theologiae ad mentem Duns Scoti dictata ab Adm. Vndo Patre Firminiano Palatino scripta vero a Patre Benevenuto Moravo Policensi tempore quo Gallus mixto milite Bavarico possidebat urbem. Pragensem".

Inc.: k. 2: „Ave Maria. Prologus. Valete nemora, valete $\mathrm{X}$ de iure et iustitia integrum terminamus in gloriam...", k. 401v.

Szkoła: Studium domesticum kapucynów w Pradze 1 Żatec. Lektor: o. Firminian Palatınus ${ }^{82}$. Skryptor: o. Benwenuty Moravo-Polıcensis ${ }^{89}$.

Karty niezapisane: 1v, 67v, 68, 69, 151,172v, 208, 287v, 402v. Na brzegu bocznym znajduje się 14 uszek pergaminowych zaopatrzonych $w$ indeksowe napisy orientacyjne. Ponad tekstem na każdej stronie jest sakralny napis:

9a Do zak. Wstąpil 13 I 1729, zm. 27 IX 1772 w Pradze. Sekretarz generalny zakonu, dwukrotny prowincjał prowincji czeskiej. - Syllabus, jw.; Catalogus Ordinis Minorum S. P. Francisci Capucinorum almae Provinciae Bohemo - Moravae pro anno 1903. Pragae $1902 \$ 51$.

93 Do zak. wstąpil 1735, zm. 19 VIII 1782 w Pradze na Hradczynie. - Syllabus, jw.; J. Truhlár: Catalogus codicum manuscriptorum latinorum qui in Bibliotheca Universitatis Pragensis asservantur. Pragae $1906 \mathrm{nr} 2679$. 
Ave Maria. Inskrypcje: k. 45v: „Finıvimus 8 augusti $1742^{\prime}$; k. 150v: „Et haec in gloriam benignissımi Authoris naturae et gratiae de matrimonio dicta sufficiant die 15 octobr. an. $1742 “ ; \mathrm{k}$. 172: „Et haec dicta sunt de sacramentis in genere et implevi hanc fenestram actu in festo S. Barbarae V. et Martyris circa octavam hora vesperi an. 1743“; k. 229: "Haec fenestra fult inscripta in festo Sancti Paul Eremitae $1 \mathrm{mi}$ Ziattecii quo tempore actu nonam diem habuerim exercitiorum, et non finita decima die mane altera die viam Pragam agressus sum ad continuandum suum studium theologicum morale... ut civitatem Pragensem a Galiis derelictam et a Principe Lobkowitz accepta videamus"; k. 285v: ,et hanc fenestram mihi valde onerosam inscripsı in... festo Stı Viti an. 1744"; k. 346: "Finivımus 20 decembris Ziatecii a. c. $1742^{\prime \prime}$; k. 401: „Finivimus die 28 augusti a. c. $1744^{\prime \prime}$.

Składkı trudne do przeliczenia.

Filigran: prawdopodobnie herb biskupı z pastorałem, k. 69, 207.

Oprawa $w$ tekturę szarą, sk. cielęca barwiona na brązowo. Okładkı obciągnięte papıerem czerpanym, klajstrowym. Szycie na 3 więzy. Kapitałka szyta jedwabna, białoniebieska. Brzegı nakrapiane na czerwono.

Proweniencja: 1. P. Benevenutus Moravo - Policensis.

2. Biblioteka OO. Kapucynów. Krosno. Pieczątla owwalna na k. 3, 58, 103, 131, 153, 186, 246, 286, 333, 358, 394. Sygn.: 23; $117-\mathrm{C}$.

K 4. Eac. $1769-1773.19 \times 15.5 \mathrm{~cm}$. K. 357. Opr. ptsk. wsp.

1. k. 1-77. „Tractatus theologico moralis de sacramentis... ace publicis Scholis in eruditionem datus“. „An. $1769 \mathrm{~m}$. 7bri. Opera Rndi Patris Michaelis Kozicki S. J."

Inc.: k. 1v: „Priusquam in... acturi simus de $\mathrm{X}$ unius anni haec et hactenus diximus sufficiunt", k. 77.

2. k. 82-206. "Tractatus theologico moralis de paenitentia, contritione et censuris... An. $1770 \mathrm{~m}$. 7bri ac publicis Scholis ad eruditionem datus". „Opera Rndi Patris Michaelis Kozickit".

Inc.: k. 82v: „Praeter essentiam sacramenti poenitentiae aliquod $\mathrm{X}$ longaevis annis laborantium finem imponimus", k. 206.

3. k. 214-304. „Tractatus theologico moralis de irure, iustitia, restitutione nec non de casibus... Anno Dni 1771 die 7bris ac publicis Scholis ad eruditionem datus. Opera Rndi Patris Michaelis Kozicki".

Inc.: $\mathrm{k} .214 \mathrm{v}$ : „Cum de iure, iustitia ac restitutione $\mathrm{X}$ pro utilitate nostra transcripsimus cedant", k. 304.

4. k. 305-343v: "Tractatus theologicus de actibus humanis iuxta divinae legis normam dirigendis in Scholis Crosnensibus Soc. Jesu explanatus ex anno 1772 in 1773. Opera Rndi Patris Igna[tii] Pilawski Auditor illius A[ntonius] Michael Konieczko".

Inc.: k. 305v: „Quoniam beatitudo aeterna finis noster est $\mathrm{X}$ et citra miraculum agnosci possunt", k. $343 \mathrm{v}$.

5. k. 350-350v. "Tractatus theologico moralis de sacramentis novae legis in gratiam discentium explanatus anno post natum Christum 1772 die 6ta 8bris in Scholis Crosnensibus". 
Inc.: k. 350v: „Proemium. Praestantissima religionis nostrae misteria $\mathrm{X}$ dissertatio $1 \mathrm{ma}$ de sacramentis novae legis", k. $350 \mathrm{v}$.

Szkoła: Kolegium jezultów w Krośnie, a po kasacie szkoła publiczna. Profesorowie: o. Michał Kozicki ${ }^{94}$ i o. Ignacy Pilawski ${ }^{95}$ T. J.

Karty niezapisane: $77 \mathrm{v}, 78-81 \mathrm{v}, 206 \mathrm{v}-213 \mathrm{v}, 231-237 \mathrm{v}, 304 \mathrm{v}, 344-349 \mathrm{v}$, 351-357v. Reklamanty. Na marginesach numery bieżących zagadnień teologicznych. Glosa marginalna na k. 57. K. 108a - to dodatkowa wkładka stanowiąca $1 / 3$ część karty o tematyce teologicznej.

Składkı: 44 kwaterniony. Kustosze literowe.

Filigrany: prawdopodobnie tarcza herbowa z kotwıcą ponad tarczą, k. 353, 357.

Oprawa jak pod $\mathrm{nr} \mathrm{K} 1$.

Proweniencja: 1. A. IM. Konieczko.

2. Biblioteka OO. Kapucynów. Krasno. Pieczątka owalna, k. 1, 30, 43, 52, 69, $85,103,123,148,175,204,247$. Sygn.: $69-\mathrm{C} ; 251$.

\section{HOMILETYKA}

K 5. Pol. 1791. $18.5 \times 11.5 \mathrm{~cm} . K .102$. Opr. ptsk. wsp.

„Kazania niedzielne roku całego. Przez X. Piotra kaznodzieję kap. miane w Rozjampolu roku Pań[skiegc] 1791. Die 11 7bris rozpoczęte".

Inc.: k. 3: "To zażalenie się Syna Boskiego daje nam $\mathrm{X}$ do pierwszej paniekąd spokojności i szczęścia“, k. 102.

Kodeks napisał o. Piotr Kumporth ${ }^{96}$, Czech. Od drugıej ręki pochodza. uzupełnienia 1 tekst od k. $88 \mathrm{v}$ do końca.

Zapıskı gospodarcze i inne: k. 20v, 21, 63, 96-97. Karty niezapisane: k. 2r, 89-90, 96, 97, 98r, 99v, 100r. Karta tytułowa przylepiona do pierwszej skỉadki, z ramką stylızowaną w kolorze czarnożóltym. W górnym polu ramki znajduje się tytuł a w dolnym kompozycja zdobnicza w kolorze żółtym, czerwonym, niebieskim, brązowym i szarym. Przedstawı ona dwa snopy zboża przewiązane szarfamı nıebıeskımı. Snopy założone na siebıe. Na kłosach prawego snopu tablıczka w różanym wieńcu, na lewym sierp $\mathrm{z}$ wiankıem bławatków. Po lewej strone pola stolik a na nim prawdopodobnie globus z kolorowymi polami. Na stole trzy ryby. Poniżej stolika w lewym rogu otwarta ksıęga $\mathrm{z}$ pszczołam, w prawym sierp.

Składki: 14. Binion 1. Od 1 do 13 ternıony i kwinterniony biegna, na przemian.

Filigrany: tarcza herbowa 1 u dołu inicjały I M, k. 93, 96, 98.

Oprawa $\mathrm{w}$ tekturę szarą, szmacıaną. Grzbiet 1 rogi skórzane, obciągnięte papierem klajstrowym $z$ ornamentem grzebieniowym. Szycie na 2 paski skórzane.

94 Ur. 23 IX 1722, do zak. wstąpił 1738. W 1. 1769-1770 uczył teologii moralnej w Krośne. W czasie kasaty zakonu był w Brześciu nad Bugiem. - Cat. Prov. Poloniae Minoris S. J. a. 1773 s. 7 ; ArSI, Pol. 37 f. $70 \mathrm{nr} 9$.

95 Ur. 2 VIII 1726, do zak. Wstąpił 1742, od r. 1760 przebywał w Krośnıe, wykładał i pełnil rózne obowlązkı w zarządzıe koleglum. - Cat. Prov. s. 7; ArSI, Pol. 37 f. 69 nr 5.

${ }^{96}$ Ur. 27 IX 17ô1, do zak. wstąpil 1784, zm. 13 II 1805 w Lublinıe. - CPP nr 416; Mortuologium podaje rok śmıereı 1806. 
Proweniencja: 1. O. Piotr Kumporth, kapucyn.

2. Biblioteka OO. Kapucynów. Krosno. Pieczątka owalnal, k. 1, 16, 28, 32, 54, 56, 78. Sygn.: $183-\mathrm{K}$.

\section{KATECHETYKA}

K 6. Pol. $X I X$ w. $20 \times 12 \mathrm{~cm}$. K. 29. Bez opr.

Katechizm.

Inc.: k. 1: „W imię Ojca i Syna i Ducha Swiętego. Amen. Modlitwa Pańska X przez laskę i miłosierdzie Boskie", k. 27v.

Poszyt liniowany ołówkiem. Karty niezapisane: 28-29. Na k. 28 podpis: Bogusz.

Składk1: 4. Kwaterniony $1-3.4$ ma $5 \mathrm{k}$.

Filigrany: fragment filigranu $\mathrm{z}$ orłem i korona, w jednym szponie berło, w drugım jabłko, w środku tarczy herbowej jabłko $z$ krzyżem i prawdopodobnie słońce.

Proweniencja: 1. Bogusz.

2. Biblioteka OO. Kapucynów. Krosno.

\section{LITURGIKA}

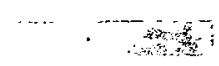

K 7. Pol., tac. 1717. $10.5 \times 7.5 \mathrm{~cm}$. K. 167. Opr. deseczki w sk. wsp. „Wyprawa przyjacielska $\mathrm{w}$ drogę szczęśliwej wieczności. Anno Domini 171715 nov[embris]".

Inc.: k. 2: "Quomodo visitandus est infirmus. In visitatione $X$ et in hora mortis meae. Amen", k. 167v.

Przygotowanie człowieka do szczęśliwej śmierci - podręcznik do użytku kapłana. Pismo jednej rękı $z$ wyjątkıem napısów na odwrocie karty tytułowej. Brak kart ochronnych. Glosy marginalne, k. 160v, 161, 162, 164-165.

Oprawa w deseczki obciągnięte sk. cielęcą barwioną na czarno, w grzbiecie dawne pękn1ęcie łatane skrawkiem pergaminu. Na wewnętrznych stronach okładek kompozycje miniaturowe wykonane farbą olejną, przedstawiające symbole śmiercı. Na odwrocie frontowej deski kompozycja z czaszka, piszczelem, otwartą ksıęgą i krzyżem, okolona wyjątkamı sekwencjı Tomasza z Celano odmawianej we mszy św. żałobnej w dzień pogrzebu: „Recordare Jesu pie, quod sum causa tuae viae, ne me perdas illa die. Quaerens me, sedist1 lassus, redemisti crucem passus, tantus labor non sit cassus". Dodano inwokację: „Hei mihı Domıne, peccavı nimis in vita mea. Miserere mei, dum veneris in novissimo die". Na wewnętrznej tylnej okladce analogiczna kompozycja z tym, że na otwartej księdze leży krzyż 1 czaszka, wokoło napis (dalszy cıąg sekwencji jw.): „Iuste iudex ultionis, donum fac remıssionıs, ante diem rationis. Ingemisco, tamquam reus: Supplicantı parce, Deus. Preces meae non sunt dignae, sed tu bonus fac benigne, ne perennl cremer igne“. Napisy wykonane na kolorowej rameczce papierowej okalającej obydwie miniatury. Oprawa posiada zapıęcie na rzemyku skórzanym, zakończonym metalową zapinką odlewaną w bronzie. Kapitałka jedwabna ręcznie wyszywana. Brzegi kolorowe zielone. 
Proweniencja: 1 .,Ad usum F. Francisci [Laziosi] ${ }^{97}$ a Varsavia Capucini ind[igni] pecc[atioris]". Napis na odwroxie k. tyt.

2. Biblioteka 00. Kapucynów. Krosno. Pieczątka owalna, k. 1, 81. Sygn.: $5-$ H.

K 8. Eac. 1763. $17 \times 9.5 \mathrm{~cm}$. K. 107. Opr. ptsk. wsp.

O rubrykach mszalnych i brewiarzowych.

Inc.: k. 7: „Pars prima de breviario. 1. Breviarum X quaesitum hunc correspondens decretorum numero", k. 105.

Kodeks dzieli się na trzy części: pierwsza (k. 7-41) omawia brewiarz, druga (42-76) rubryki brewiarzowe, trzecia (79-105) rubryki mszalne. Reklamanty. Paginacja oryginalna od k. 7: 211, nlb. 5. Karty nıezapisane: 1-6, $76 \mathrm{v}, 77,78,105 \mathrm{v}, 107 \mathrm{v}$. "Index rerum in hoc libro contentarum", k. 106-107. Numery paragrafów na marginesach. Kodeks pısany dwiema rękami. Dopiski na wyklejkach jeszcze innymi rękami. Glosy marginalne. Liczne poprawki.

Składki: 14. Terniony na przemian $z$ kwinternionami.

Filigrany: tarcza herbowa z koroną i dwoma krzyżami (może Gdańsk) oraz inicjały S M, k. 3, 4, 77, 78.

Oprawa w tekturę szarą. Grzbiet i rogi obciągnięte sk. barwioną na brązowo. Okładki obciągnięte klajstrowym brązowym papierem czerpanym. $\mathrm{Na}$ frontowej wyklejce wycisk drzeworytniczy motywu roślinnego z czterokątną koniczynką. Szycie na 3 sznurki. Kapitałka zwykła. Brzegi koloru czerwonego.

Proweniencja: 1. „R. D. Wieżadłowski, Prof. Sem. Prem[isliensis]".

2. „R.D. Joannes Baptista Paszkiewicz, Vic[arius] Ecal[esiae] Crosmen[sis]“".

3. Bibliotelka OO. Kapucynów. Krosno. Pieczątka owalna, k. 7, 27, 44, 72, 103. Sygn: : $15-F: 507$.

K9. Pol., łac. XIX w. $20 \times 16.5 \mathrm{~cm}$. K. 232. Opr. płsk. wsp.

Zbiór pieśni religijnych.

Kodeks utworzony $z$ papieru zwykłego białego (k. 1-202, 227-232) i czerpanego prążkowanego (k. 203-226). Paginacja oryginalna: 472. Karty niezapisane: $49 \mathrm{v}-54 \mathrm{v}, 104-134,150-160 \mathrm{v}, 199 \mathrm{v}-202 \mathrm{v}, 206-217 \mathrm{v}, 219-226 \mathrm{v}$, 231. „Rejestr czyli zbiór pieśni w tej ksią[żce] zawartych“ (nie ukończony), k. 232. Na k. 1-11,55-72, 135-149 wycięte ramki a w ich miejsce wklejone drukowane teksty pıeśni. Wlepione pieśni: k. 75, 161-164. Pieśni rękopiśmienne: k. 12-49, 73-103, 165-199, 203-205, 227-230.

Filigrany: orzeł z koroną zakończoną krzyżem, w szponach miecz i berło, pod tarczą inicjały I B, k. 206, 207.

Oprawa twarda. Grzbiet skórzany czarny, tektura biała. Papier chagrain niebieski, prasowany, $z$ tłoczoną liniami rameczką na ciemno. W pośrodkut na frontowej I tylnej okładce wycıśnięty krzyż. Wyklejka papier biały zwykły.

Proweniencja: Biblioteka OO. Kapucynów. Krosno. Pieczątka orwalna, 1k. 1, 2 , $10,24,41,59,75,104,135,139,150,172,203$. Sygn.: $418-\mathrm{H}$.

${ }^{97}$ Ur. 20 IX 1678, do zak. Wstąpił 1698, zm. 7 III $1761 \mathrm{~W}$ Krakowie. Przez 8 lat spelnıał urząd komisarza generalnego Kapucynów $\mathrm{w}$ Polsce, - CPP nr 2; O. A $A_{i}$ Wo j n a r, jw. $\mathrm{s}$. 23, 68; Ks. Z. O b e rty ńs k 1, Jw. s. 221-225; Mortuologıum podaje datę śmierq1 6 III; Catalogus scriptorum s. 22. 


\section{TEOLOGIA ASCETYCZNA I IMISTYCZNA}

K 10. モac. 1771. $18.5 \times 11 \mathrm{~cm}$. K. 54. Opr. ptsk. wsp.

„Diarium sententiarum ad regulandam vitam religiosorum ex sententiis patrum in singulos dies rite dispositum et a P. F. Columbano Capucino conscriptum anno quo factor dierum luce nova natus est".

Inc.: k. 4: „Januarius. Sic ordinare vitam quasi annus hic $\mathrm{X}$ officii absolutationem debitam exhibet nobis", k. 54 .

Kodeks wykonany jedną ręką $\mathrm{z}$ wyjątkiem bıografii autora na wyklejce frontowej. Autorem jest o. Kolumban Peniżek ${ }^{88}$ "Czech. Rozważania duchowne podzielone są na 12 miesięcy. Początek miesıąca zaznaczony jest tuż pod górną linıą ramki. Na dalszych kartach nazwa poszczególnych miesięcy biegnıe ponad linıą ramki w formıe żywej paginy. Rozważania na każdy dzień miesıąca zaznaczone są liczbami bieżącymi na marginesıe ramkı. Karty niezapisane: $1 \mathrm{v}, 2,3,54 \mathrm{v}$.

Składki: 7. Po ternionach następują na przemian kwaterniony.

Filigrany: tarcza herbowa $\mathrm{z}$ koroną, $\mathrm{w}$ polu róg bawoli; k. 2, 5. Napis: Van, k. 1.

Oprawa w tekturę szarą. Grzbiet i rogi w sk. cıelęcą, brązową. Papier czerpany, marmurek grzebienıwy silnie wytarty. Szycie na 2 paski pergaminowe.

Proweniencja: 1. Napis na wyklejce frontorwej: „Fr. Columbanus a Sieradicio. Sanguine obscurus... Charactere sacerdos. Stemmate servus. Tibi amantissime Deus hanc manuum suarum offert corde devoto opellam. Anno Domini 17 II $^{2}$ Lubartoviae concinnatam”. Jest autograf autora. Inna ręką dodano po "Sieradicio” - „Pieniązek Boemus", po "sanguine" - „nobilis'. Dalej następuje biografia autora wykonana ta samą korektorska, ręką: „Hic sacerdos absolutus theologus natus 172218 actobr. ingressus est nostrum ordinem Cracoviae anno 1745 die 3 aprilis. Functus officiis concionatoris, vicarii, guardian1, lectoris, plenus meritis obiit Mariampoli in Pokutie, ubi nunc existunt sorores charitatis. Anno Dni 1784 obiit die 5 iulii ibique in corona fratrum sepultus requiescit in Domino amen".

2. Biblioteka OO. Kapucynów. Krosno.

K 11. Eac. 1783. $17 \times 10 \mathrm{~cm} . K .120$. Opr. sk. wsp.

„Directorium perfectionis religiosae seu in spirituali profectu faciendi progressus per lectionem spiritualem utilissima methodus tradita collectaque ex variis libris asceticis proprio usui accomodata. Anno a Partu Virginis 1783".

Inc.: k. 3: „Cuilibet siquidem christiano eo magis vero $\mathrm{X}$ cunctasque periodos et quodlibet iota offero", k. 119.

Kodeks napısany w całoścı przez o. Tadeusza Krawczyńskiego, i przeznaczony dla nowicjuszy kapucyńskich. "Index consideratıonum et meditationum“. k. $119 \mathrm{v}, 120$. Paginacja oryginalna: nlb. 1, 231, nlb. 3. Na odwrocie karty tytułowej znajduje się wlepiony sztych, drukowany, z symbolami doskonałości chrześcıjańskiej z napısem u góry: ',Idea novitii perfecti“. U dołu w małej ramce cytat $z$ listu św. Pawła do Galatów 5, 24. Ponad sztychem odręczny napis: „Renovamini Spiritu“, poniżej: „Inspice et fac secundum exemplar",

${ }_{98}$ Ur. 18 X 1722, do zak. wstąpił 1745, zm. 5 VII 1784 w Marıampolu, - CPP nr 96; Mortuologıum podaje datę śmierci 5 VIr. 
Exod. 25, 40. Na odwrocie k. 104 sztych przedstawiający symbol odkupienia w kolorze biało-czarno-czerwonym.

Składki: 15. Ternion 1. Pozostałe kwaterniony. Kustosze literowe od A-P.

Filigrany: Matka Boska z Dzieciątkiem, k. 1 .

Oprawa w tekturkę obciągniętą $w$ sk. cielęcą barwioną na brązowo. Szycie na 2 paski pergaminowe.

Proweniencja: 1. O. Tadeusz Krawczyński.

2. O. Damazy Stehlik. „Pro simplici usu Fratris Damasi Capucini indigni. Ab A. V. Patre Thadaeo lectore descripta mihique concessa $1784^{\prime \prime}$. Wyjaśnienie na $\mathrm{k}$. tytułowej wypisane ręką o. Damazego.

3. Biblioteka OO. Kapucynów. Krosno. Pieczątka owalna, k. 2, 55, 82. Sygn.. $299-\mathrm{H}$.

\section{HISTORIA KOSCIOEA}

K 12. Pol. $X X$ w. $21 \times 17 \mathrm{~cm} . K$. 130. Bez opr.

„Maurycy Meschler ${ }^{99}$ T. J., Ustawy Towarzystwa Jezusowego i ich skutki. Z pierwszego i drugiego wydania niemieckiego". Przietłumaczył ks. Michał Goryl ${ }^{100}$.

Tekst tłumaczenia posıada oryginalną paginację: nlb 1, X, 247.

Praweniencja: Biblioteka OO. Kapucynów. Krosno. Pieczątka owalna, k. 1, 29, 91. Sygn.: $59-\mathrm{D}$.

\section{FILOZOFIA SCHOLASTYCZNA}

K 13. Eac. 1737. $20.5 \times 16.5 \mathrm{~cm}$. K. 216. Bez opr.

1. k. 1-175v. „Philosophliae thomisticae tomus 1mus. Logica maior in 3 partes secundum 3 mentis operationis divisa".

Inc.: k. 1: "Antequam ad singulas logicae partes descendamus $\mathrm{X}$ habitus hinc impediat ab actu“, k. 175v.

2. k. 176-216v. "Philosophiae thomisticae tomus 2dus de physica".

Inc.: k. 176: "Physica est nomen graecum idem latine $\mathrm{X}$ cum qua forma substantialis explet et...", k. 216v.

Kodeks nie posiada karty tytułowej ani końca. Pierwsza karta odłączona od składk1. Reklamaty występują przy końcu prawie każdej k. v. Glosy marginalne: k. $33,35 \mathrm{v}, 45 \mathrm{v}$. Bardzo często $\mathrm{w}$ gómym marginesie znajdują się inicjały LJC, czasem dochodzi jeszcze Amen. Daty: k. 164v: „Die 17 rulii“; k. 176: ,7 8bris 1737". Rysunek na k. 100v: „arbor Porphyrii“. Kodeks bardzo zniszczony.

Składki: 39. Binıony 9, 14-33. Terniony 8, 34, 35, 39 bez $3 \mathrm{k}$. Kwaterniony $1-7,10-13,36-38$. W drugiej częścı kodeksu składkı numerowane kustoszamı liczbowym1: $\mathrm{N} 1-\mathrm{N} 6$.

Filigrany: tarcza herbowa z koroną i inıcjałami MI I, k. 82, 83.

Oprawa całkowicie zniszczona. Pozostało tylko szycie na 3 sznurki.

Proweniencja: Bibliotekla: OO. Kapucynów. Krosno.

${ }_{99}$ Ur. 19 IX $1830 \mathrm{w}$ Brig W Szwajcarii, zm. 2 XII 1912. Autor wielu dzıel ascetycznych. For, Lexicon fur Theologie und kirche. Wyd. M. B u ch be rger. Bd. 1-10. Freiburg 1. Br. 1930-1933. T. 7 s. 112; Enc. Chetm. XXVII/XXVIII 14.

100 Ur. 1853 w Jarosławiu, wyśw. 1879, proboszcz w Ustrobnej w r. 1907. W schematyzmach diecezji przemyskıej figuruje do r. 1913. 
K 14. Eac. $1740.20 .5 \times 16.5 \mathrm{~cm} . K .178$. Opr. ptsk. wsp.

„Flores philosophiae de radice peripatetico-scotistica excepti a Fratre Benevenuto sub auspiciis Adm. Venerandi Patris Firminiani Palatini lectoris ac moderatoris nostri dignissimi Znoymae".

Inc.: k. 2: „Prologus. Quin sapientia naturae rationalis merces $\mathrm{X}$ et excludat actualem formidinem sat certus et incertus suo", k. 176v.

Szkoła: Studium domesticum kapucynów w Znojmo. Prof.: o. Firminian Palatinus. Skryptor: Fr. Benwenuty Moravo - Policensis.

W tytulaturze chronostych podający rok powstania rękopisu. Karty niezapisane: 177-178v. Dukt pisma łukowaty. Glosa marginalna na k. 14v, 69. Każde zagadnienie filozoficzne kończy się lacińską wierszowaną sentencją. Inskrypcje: k. 65: „die 28 1anuarii 1740“; k. 171v: „et 8 1unii a. 1740 devolut1s finivımus"; k. 171: wiersz laciński z okazji zakończenia studium filozofii w dniu 8 czerwea 1740 - „Siste viator, inspice et inquire hoc in chartaceo tumulo, litterarum cumulo, quis sepultum iaceat..."; k. 172v-176v: „Theses ex philosophia rationali luxta inconcussa dogmata Ioannis Duns Scoti Doctoris Subtilis".

Składki: 15. Kwinternion 1. Pozostałe seksterniony. Kustosze literowe od N 1.

Filigrany: slady filigranu, k. 176.

Oprawa pólmıękka w tekturę szarą. Grzbiet i rogı w sk. cielęcą, barwioną na brązowo. Okładki obciągnięte w papier czerpany, barwiony na brązowo. Kapitałka szyta jedwabna w kolorze białoniebieskim.

Proweniencja: 1. P. Benvenutus Moravo - Policensis.

2. „Haec logica ad usum Fratris Antonini [Przedwojewski] Zdzanensis accomodata". Napis ma wyklejce frontowej.

3. Biblioteka OO. Kapucynów. Krosno. Pieczątisa owalna, k. 1, 22, 66, 96, 125, 154. Sygn.: $24-\mathrm{F}$.

K 15. Łac. 1767. $19 \times 15.5 \mathrm{~cm}$. K. 254. Opr. ptsk. wsp.

„Institutiones philosophicae secundum verae religionis dogmata et ad praescriptam recens Scholis nostris normam discentium usui propositae... in Scholis Crosnensibus 1767 opera Rndi Patris Casimiri Grabiński. Michaelis Konieczko".

Inc.: k. 1v: „Philosophia si vox spectatur amorem sapientiae $\mathrm{X}$ qui ergo hactenus dictavit satis interim habet", k. 254v.

Szkoła: Kolegium jezuitów w Krośnie. Prof.: o. Kazimierz Grabıńskı. Skryptor: Antoni Michał Konieczko. Na marginesach numery bieżących zagadnien filozoficznych.

Filigrany: motyw kwiatowy w owalu, poniżej ınıcjały $\mathrm{F} \mathrm{S}, \mathrm{k} .247$.

Oprawa w tekturę szarą. Grzbiet i rogi w sk. cielęcą. barwıoną na brązowo. Papier czerpany klajstrowy, jasno brązowy. Szycıe na 3 więzy.

Proweniencja: 1. Antoni Michal Konieczko.

2. Biblioteka OO. Kapucynów. Krosno. Pieczątka owaina, k. 1, 2, 41, 80, 112, 114, 144, 184, 233. Sygn.: $23-$ F.

K 16. Łac. $1780.24 .5 \times 16.5 \mathrm{~cm}$. K. 91. Opr. ptsk. wsp. „Philosophiae ecclesiasticae pars $1 \mathrm{ma}$ complectens metaphysicam 
discentium usui in Scholis S[acrae] C[aesare]o R[egi]ae M[aiesta]tis Crosnensibus proposita. A Perillustri Rdo Dno Ioanne Nepomuceno Pruski praefecto Scholarum Crosnensium professore philosophiae. Anno Christi 1780. Die 1ma martii Stanislai Urbański mp."

Inc.: k. 2: „Introductio ad metaphysicam. I. Metaphysica scientia entis rerumque immanalium $\mathrm{X}$ ex utralibet laborantem Xristoque offusum", k. 81v.

Szkoła: Cesarsko-królewska w Krośnie. Prof.: ks. Jan Nepomucen Pruski. Skryptor: Stanisław Urbańskı.

Karty niezapisane: 82-91. Na marginesach numery paragrafów poszczególnych zagadnień filozoficznych. Glosy marginalne występują bardzo rzadko. W tekście liczne podkreślenıa 1 poprawki.

Składkı: 23 biniony.

Filırany: tarcza herbowa $\mathrm{z}$ koroną, $\mathrm{w}$ polu róg bawoli na taśmie, poniżej dzwonek i napis: C \& I Honig.

Oprawa w makulaturę rękopiśmienną. Grzbiet 1 rogi obciągnięte sk. bydlęcą barwioną na brązowo. Okładkı obcıągnięte papıerem czerpanym nakrapianym na brązowo. Oprawa zhıszczona. Szycie na 3 sznurki. Wyklejka, jak i składki ręlkopisu, posiada co drugą kartę nie przyciętą do formatu lecz założoną do wewnątrz.

Proweniencja: 1. Stanisław Urbańskij, k. 1.

2. Biblioteka OO. Kapuynów. Krosno.

\section{RETORYKA I FOETYKA}

K 17. Eac., pol. $1694-1696.19 .5 \times 15.5 \mathrm{~cm}$. K. 247. Opr. perg. wsp.

1. k. 1-27v. "Gradus ad Tulliana sarmaticae eloquentiae rostra seu compendiosa oratoriae facultatis institutio proposita. In Collegio Balozaręboviano Crosnensi Societatis Jesu. Anno Dni 1694 in quintum".

Inc.: $\mathrm{k}$. 1v: „Ad Tulliana rostra vobis gradum pono $\mathrm{X}$ expositus in numen evad. sodalium. Dixi“", k. 27v.

2. k. $28-59 \mathrm{v}$. „Gradus ad sublimiora scientiae philosophicae adita seu compendiosa in Aristotelis philosophiam introductio vulgo dialectica. Breviter proposita in Collegio Balozaręboviano Societatis Jesu. Anno 16956 iunii".

Inc.: k. 28v: „Post erectum (quantum per angustia anni licuit) ad Tulliana sarmaticae eloquentiae $X$ praemissae invariatae sunt", k. $59 \mathrm{v}$.

3. k. $62-104 \mathrm{v}$. "Candidatus reginae eloquentiae per longum institutionis oratoriae praeceptorum brevius exemplorum iter deductus. Anno... 1695".

Inc.: k. 63: „Lubet non alio sidere aut peregrina $\mathrm{X}$ advoluti plantis perenniter parebimus. Dixi", k. $104 \mathrm{v}$.

4. k. 105-247. „Elysium eloquentiae inter Carrathiorum iuga montium per oratorias praeceptiones rhetoribus Coll. Crosn. Soc. Jesu demonstratum. Anno... 1696". 
Inc.: k. 105v: "In Elysium vos oratoriae immo et omnimodae $\mathrm{X}$ tibi ver flore notabunt. Dixi", k. 247.

Szkoła: Kolegium jezuitów w Krośnie. Profesorowie: Krzysztof Wierzbickn ${ }^{101}$ w r. 1694, o. Józef Olechowicz ${ }^{102}$ w r. 1695, o. Marcin Szopniewski ${ }^{103}$ w r. 1696. K. 158: „Sub R. P. Ostrowski a 107 bris 1697 “.

Reklamanty. Karty niezapisane: 60, 61, 131r, 153v, 161, 187v, 208, 209, 247v. Niektóre $z$ nich przeznaczone były na wypisanie tytułów omawianych zagadnień ale $z$ nieznanych powodów skryptor zaniechał tej pracy. Rysunki: $k$. 35: ,arbor porphyriana“, k. 47v, 48v: wykresy. K. 83a - to wklejka z r. 1750 kwitująca odebranie pudełka z precjozamı przez Wojciecha Weluńskiego od plebana jureckiego Jurków. K. 195-207v: „Declamatıo tempore Bacchanaliorum Crosnae 1696".

Składki: 33. Biniony $1-7,14,15,18,20,24,26,28,29,31,32,33$. Ternıony 8-13, 16. Kwaterniony 17, 19, 22, 23, 27, 30. Kwinternion 21. Okternion 25.

Filigrany: listek $z$ inıcjałam I H S, k. 60.

Oprawa półmıękka, klejona $\mathrm{z}$ papieru i płótna szarego. Grzbiet jak $i$ frontowa $i$ tylna okładka obciagnięte pergaminem. $\mathrm{Na}$ okladce tłoczona ręcznıe bordiurka z motywem kółek. W narożnikach ramki tłoczonej na ciemno filigranowe stemple $\mathrm{z}$ powtórzeniem $\mathrm{w}$ pośrodku zwierciadła. Szycie na 3 sznurki.

Proweniencja: 1. Pleban jurecki.

2. Biblioteka OO. Kapucynów. Krosno. Pieczątka onwalna, k. 1, 33, 62, 63, 86, 147, 197, 208. Sygn.: $15-\mathrm{N}$.

K 18. Eac., pol. $1726-1729.19 \times 15.5 \mathrm{~cm}$. K. 185. Opr. ptperg. wsp.

1. k. 1-61v. "Maiestas entheo poetico menti Apollineae erecta. Tot praesidiis quot praecepti praxeos dogmatis circumambita ab Illustribus neopoetis in Collegio Lubomirsciano Ressoviensi Scholarum Piarum adorata. Anno quo Maiestatem in aula virginali Homo Deus occupavisse extruxit seque idem creditur".

Inc.: k. 3: „Votum Reginae caelitum V. Mariae occupatrici X inferiorum abyssus deglutiat iniquitatis motorem", k. $61 \mathrm{v}$.

2. k. $62-185$. ,Vita orbis universi rhetorica in praxibus cuiusvis aetati competentibus laboriosa in sententiis historiis vitae mortali consonis immortalis per cursum omnium aetatum deducta. Ad clarissimum orbi sarmatico Lubomirsciani Szreniavae speculum emendata. Atque ex Lycaeo Ressoviensi Scholarum Piarum in varios usus pro immortalitate vitae laborantis Polonae iuventuti amandata. Anno... 1728 in 1729".

Inc.: k. 67: „Amplificatio verbalis est verbi unius $\mathrm{X}$ quos ad Chocimium Joannes Sobieski profrigavit", k. $184 \mathrm{v}$.

Szkoła: Kolegium pıjarów w Rzeszowıe. Reklamanty. Karty niezapısane:

101 Ur. 12 III 1661, do zak. wstąpil 1682, zm. 10 XII 1720 w Ostrogu. - ArSI, Pol, 69 f. 364; N les deckl IX 312; Ks. J. B row n, Jw., s. 423; Est r. XXXII 481-482.

102 Ur. 21 III 1665, do zak. wstąpil 1687, zm. 30 IX $1699 \mathrm{w}$ Poznanıu. - ArSI, Pol. 20 f, 136 nr 50; Necrol. Poloniae (1612-1700) f. 1074.

19s Ur. $30 \mathrm{X} 1661$, do zak. wstąpił $1677, \mathrm{zm} .26 \mathrm{~V} 1708 \mathrm{w}$ Jurewiczach. - ArSI, Pol. 20 f. 86 nr 5. 45 f. 316 . 
k. 2, 5v, 177v. Skąpe glosy marginalne. Kodeks wykonany kilkoma rękami. Rysunkı: k. 21: „Exemplum de sacra Synaxi“; k. 178-182v: „Index vocabulorum".

Składki: 44. 1, 2 po $2 \mathrm{k}$. Kwaterniony 1, 28. Seksterniony 24, 27, 37. Pozostałe biniony.

Filigrany: niezidentyfikowany, k. 54.

Oprawa broszurowa. Grzbiet wzmocniony pergaminem. Kartki zewnętrzne rękopisu zaklejone papierem brokatowym prasowanym, zabarwione na kolor wıśnıowy. Od środka na wewnętrznych zawınięciach papieru brokatowego ślady dawnych złoceń. Szycie na 3 sznurki.

Proweniencja: Biblioteka OO. Kapucynów. Krosno. Pieczątka owalna, k. 26, 38, $46,57,70,88,151$. Sygn.: $226-\mathrm{S}$.

K 19. Łac., pol. 1763-1766. $20 \times 16 \mathrm{~cm}$. K. 212. Opr. plsk. wsp.

1. k. $3-76 \mathrm{v}$. „Lucubrationes oratorij quatuor annorum intervallo Scholae Rhetorices auditoribus traditae ac primum exercitationes in Scholis Crosnensibus propositae a Rndo Patre Joanne Lemański Soc. Jesu die 10 7bris anno Domini 1763. Dante operam praeceptis rhetorices An[tonio] Mi[chaële] Konieczko".

Inc.: k. 4: „Exempla narrationis perspicuae. 1. Pewien chcąc $\mathrm{X}$ et ultra quam diu tu Deus eris Deus. Amen", k. 76v.

2. k. 77-180v. „Lucubrationes rhetoricae. Opera auditorum eloquen. tiae tum patrio tum latino idiomate in Scholis Crosnensibus Collegii Societatis Jesu litteris operam navantium concinnata. Anno D. 1765 die 12 7bris. Sub Rndo Patre Fran[cisco] Stokowski Societatis Jesu. Ann. 3. Dante operam praeceptis rhetorices A[ntonio] Mi[chaële] Konieczko".

Inc.: k. 80: „Expositio: Bogu po trzykroć najdobrotliwszemu $\mathrm{X}$ nil semper suo statu manet. Sub sole nihil stabile", k. 179.

3. k. 181-210v. „Praecepta rhetorica exemplis Ciceronianis tum imitationibus eorundem latino ac patrio idiomate per Clarissimum et Admodum Rndum Dnum M. Benedictum Josephum Ostański philosophiae doctorem Tarnoviensis eloquentiae vigilantissimum professorem explanata anno Domini 1766 inchoata. Dante operam isdem praeceptis An[tonio] Michaële Konileczko".

Inc.: k. 182: „Cum ad bene ornateque dicendum $\mathrm{X}$ że dla ciebie żyć pragnie, dla ciebie umierać", k. 210v.

Szkola: Kolegium jezuitów w Krośnie. Profesorowie: o. Jan Lemański ${ }^{104}$, o. Franciszek Stokowski ${ }^{105}$, ks. Benedykt Józef Ostański ${ }^{108}$, prof. Kolonii Akademickiej w Tarnowie.

104 Ur. 2 II 1732, do zak. wstąpił 1743. W okresıe kasaty zakonu przebywal w Brzesciu nad Bugiem. - Cat. pers. et offic. Prov. Poloniae Major1s S. J. ex a. 1773-1774. Posnaniae S. 7; ArSI, Pol. 37 f. 15.

105 Ur. 2 X 1735, do zak. wstąpil 175i. W I. 1764-1765 przebywal w Krośnie. - ArSI, Pol. 37 f. $126 \mathrm{nr} 3$.

106 Estr. XXIII 491-492; J. Leniek: Ks. Izydora Chrościńskiego, pierwszego pretekta 
$\mathrm{Na}$ marginesach numery bieżących zagadnień. Glosy marginalne bardzo rzadkı. Na okładce błędnie wytłoczony na ślepo tytuł: „Lucubrationes gratori“. Inskrypcje: na odwrocie $\mathrm{k}$. tytułowej: „Collectıo in unum huius operis uno anno finita in 9bri 1775to".

Filigrany: Matka Boska z Dzieciątkıem w otoku promieni, k. 206, 207. Inicjały $\mathrm{AD}$ z krzyżykiem. w górze, k. 12.

Oprawa w tekturę szarą. Grzbiet i rogi skórzane, płsk. clelęcy barwiony na brazowo. Koło więzów bordiurka tłoczona na ciemno. Papier okładki klajstrowany, brązowy. Szycie na 3 więzy. Brzegi silnıe nakrapıane na czerwono.

Proweniencja: 1. Antoni Michał Konieczko., k. 3, 77, 181.

2. Biblioteka OO. Kapucynów. Krosno. Pieczątka owalna, k. 3, 34, 76, 125, 145, 186. Sygn.: $16-\mathrm{N}$.

\section{LITERATURA PIE్KKNA}

K 20. Pol. II poł. XVIII w. $17.5 \times 15.5 \mathrm{~cm}$. K. 160. Opr. sk. wsp. Poemat o Józefie Egipskim.

Inc.: k. 1: "Tobie o Matko niezrównanej mocy X Józefowego ten jest tryb żywota. Koniec", k. 160.

Kodeks w całości napisany przez o. Andrzeja Dobrawskiego, kapucyna. $\mathrm{W}^{\prime}$ skazuje na to podpıs $\mathrm{w}$ formie inicjału na końcu poematu: A wplecione $\mathrm{w}$ dużą literę $\mathrm{S} z$ dopiskiem mppria. O. Andrzej był autorem szeregu utworów poetyckich. Część z nıch dochowala się w kapucyńskich zbiorach archiwalnych 1 bibliotecznych. Kodeks dostał się prawdopodbnie do Krosra po kasacie klasztoru w Olesku w r. 1785. Cały utwór podzıelony jest na 13 pieśni. Każda pieśń zaczyna sıę wierszowanym skrótem (synopsis) zawierającym jej treść. Poszczególne wiersze ponumerowane liczbamı ciagłymi. Brak karty tytułowej. $\mathrm{Na}$ tylnej wyklejce i k. 160 rysunek 5 żołędzı z dawnych kart do gry.

Składki: 20. Ternion 1. Kwinternion 2. Pozostałe kwaterniony.

Filigrany: Tarcza herbowa $z$ koroną, $w$ polu róg bawoli, k. 14. Napis: JI Arochie, k. 11, 19, 67.

Oprawa w tekturę szarą, obciągnıętą sk. cielęcą barwioną na brązowo. Szycie na sznurkı z 3 wıęzami. Slady kapitałki szytej.

Proweniencja: 1. O. Andrzej Dobrawski.

2. Biblioteka OO. Kapucynów. Krosno. Pieczątka owalna, k. 1, 54, 102. Sygn.: $71-\mathrm{S}$

\section{MEDYCYNA}

K 21. Pol. XIX w. $21.5 \times 17.5 \mathrm{~cm}$. K. 29. Bez opr.

Zbiór recept i rady praktyczne.

Karty niezapisane: $2 \mathrm{v}, 3,14,19 \mathrm{v}, 21,29 \mathrm{v}$.

Składkı: 4. 1 ma $2 \mathrm{k}$. Ternion 3. Kwinternion 4 bez $1 \mathrm{k}$. Seksternion 2.

Proweniencja: 1. Zygmunt Kralizek. Podpis na frontorwej k. rękopisu.

2. Biblioteka OO. Kapucynów. Krosno. Pieczątkła orwalna, k. 1, 2, 5, 9, 15, 20. Sygn.: 273.

gimnazjum tarnowskıego, kronika z lat 1784-1794. W: Archiwum do dziejów literatury 1 ośuiaty $w$ Polsce. T. 9. Kraków 1897 s. 401. 


\section{RÓŻNE}

K 22. Eac., pol., niem., franc. II pot. XVIII w. $19 \times 12 \mathrm{~cm} . K .69$. Opr. ptsk. wsp.

Zbiór zapisków o różnej treści.

Inc.: k. 1: „Carmen serpentinum vota applaudentium colligens $\mathrm{X}$ exercitium 150 mahl warum $216 \mathrm{mahl}^{64}, \mathrm{k} .69$.

Zbıór zapisków o treści ascetycznej, hıstorycznej, farmaceutycznej, poetycklej, astronomıcznej, z historii zakonu, satyry, chronostychy, listowniki itd. Wzory 1 formularze aktów urzędowych dla kancelarii kapucyńskiej: k. 11, 25, 26, 27, 28, 37-43v. Kodeks napisany przez o. Oliweriusza Leảl'a ${ }^{107}$, Czecha. Karty niezapisane: k. $34 \mathrm{v}, 57 \mathrm{v}, 66 \mathrm{v}$. Glosy marginalne: k. 16. Liczne podkreślenia 1 poprawkı $\mathrm{w}$ tekścıe.

Składki: 9. Binıon 9. Kwaternıony 1-7. Kwinternion 8.

Fil.grany: tarcza herbowa $z$ koroną 1 rogiem bawolim $w$ polu, $k .2,6$. Nazwısko: C \& I Honıg, k. 16. Na wyklejce tarcza herbowa i napıs: Zoon.

Oprawa półmıękka w tekturę sklejaną. Grzbiet i rogi skórzane, obciągnięte papierem marmurkowym, grzebieniowym. Szycie na 2 sznurki.

Proweniencja: 1. O. Oliweriusz Ledl.

2. Biblioteka OO. Kapucynow. Krosno. Pieczątka owalna, k. 2, 15v, 26, 55v. Sygn.: $144-$ S.

\section{REKOPISY BIBLIOTEKI KLASZTORU W ROZWADOWIE}

\section{TEOLOGIA DOGNATYCZNA}

R 1. Eac. 1747. $20 \times 16.5 \mathrm{~cm}$. K. 215. Opr. brosz. wsp.

„Librorum de theologicis disciplinis tomus I continens prolegomena ac disputationes de existentia ac proprietatibus unitus Dei. Tyronibus Augustinensibus per Fratrem Erasmum Bartolt ${ }^{108}$ eiusdem Ordinis explanatae".

Inc.: k. 1v: „Quarum disciplinarum theologicarum notitia melior $\mathrm{X}$ ut nemo desperet, exhonescat nemo", k. 208.

Kodeks posiada paginację oryginalną: 420 , nIb. 14. Karty niezapisane: $209 \mathrm{v}$, 212-215. Inskrypcje: k. 209: "Theoremata sacra historico apologetico polemica, dogmatica, scholastica per fratres Eremitas Augustinıanos pubiico commissa certamini anno vulgaris erae MDCCXLVII Cracowiae ad S. Catharinam"; k. 210-21lv: ,Augustınensis theologiae propositıones". Na wyklejkach zapisk1 o treści teologiczne].

Składkı: 18 seksternionów. Kustosze lıczbowe.

Filıgrany: mężczyzna z kielichem, nıewiasta z bukıetem kwiatów, ponad nimi napıs: Egendorff, k. 214.

107 Ur. 14 I 1737, do zak. wstąpił 1757, zm. 11 XI 1802 W Krośnı. - CPP nr 232; Mortuologlum, jw.

108 Ur. 1716, do zak. Wstąpil 1ri36, zm. 1 X 1.786. Regens stuajum W generalnym konwencie krak., prowincjał. - o. G. U th: Szkic historyczno-biograficzny zakonu augustiańskiego w Polsce. Kraków 1930 s. 310-314. 
Oprawa broszurowa. Grzbiet - papier ręcznie barwiony na czerwono. Okładka obciągnięta papierem czerpanym zielonym z tłoczeniami na złoto z bogatym deseniem filigranów rokokowych. Wewnątrz bardzo wyraźnie zachowany w kolorze. Grzbiet znıszczony.

Proweniencja: 1. O. Erazm Bartolt, augustianin.

2. „Ego Romualdus Siekacz[ynensis] filius Constantii Crasno[staviensis] hunc librum obtuli ad Conventum eiusdem". Napis na wyklejce frontowej.

3. Bibilioteka OO. Kapucynów w Rolzwadowie. Pieczątka akrągła, na wyklejkach. Sygn.: 213.

R 2. Eac. 1747. $20 \times 16.5 \mathrm{~cm}$. K. 134. Opr. brosz. wsp.

"Librorum de theologicis disciplinis tomus tertius qui complectitur dissertationes de originali peccato, de haeresibus adversus liberum arbitrium, et gratiam, atque de ipsa gratia reparatoria. Iuventuti Augustinensi per Fratrem Erasmum Bartolt eiusdem Ord[inis] professum explanatus".

Inc.: k. 1: „Liber 13. In ipso originalis peccati $\mathrm{X}$ ipsius augendae causam. Anathema sit", k. 127.

Kodeks posiada paginację oryginalną: 240 , nlb. 7 . Karty niezapisane: $127 \mathrm{v}$, 130v, 131-134. Rzadkie glosy marginalne. Rękopis napisany ręką o. Erazma Bartolta, augustianına z Krakowa. „Propositiones“ na k. 128-130. Na wyklejce frontowej ,arbor porphyriana“, na tylnej tekst z logiki.

Składkı: 11 seksternionów. 10 bez $1 \mathrm{k}$. Kustosze liczbowe.

Filigrany: mężczyzna $\mathrm{z}$ kielichem, niewiasta $\mathrm{z}$ bukietem kwiatów, ponad nimi napis: Egendorff, k. 129, 131. Na wyklejce tarcza herbowa z korona.

Oprawa broszurowa. Grzbiet papier malowany na zielono z ornamentem prasowanym, obclągniętym papierem klajstrowym, ręcznie zapuszczanym na żólty kolor.

Proweniencja: 1. O. Erazm Bartolt, augustianin.

2. „Fr. Romualdus Siekacz[ynensis] filius Constantii Crasnosta[viensis] hunc librum "redidit". Napis na wyklejce frontowej.

3. Biblioteka OO. Kapucynów w Rozwadowie. Pieczątka okrągła na wyklejkach. Sygn.: 322.

R. 3. Łac. I poł. XVIII w. $21.5 \times 18 \mathrm{~cm}$. K. 325. Opr. ptsk. wsp.

"Theologia speculativa".

Inc.: k. 3: "Partitio totius theologiae. Solum agressum $\mathrm{X}$ in honorem Numinis iustissimi dicta sunt", k. $321 \mathrm{v}$.

Kodeks bez karty tytułowej. Karty niezapisane: 1, 2, 112. 113, 124-129v. Od k. 104 do $152 \mathrm{v}$ na margınesach numery paragrafów. Częste podkreślenia w tekście. Dolny brzeg nieco zaplamiony atramentem, jak równı́z k. $110-113$, 199v, 200. Glosy marginalne, k. 134.

Składki: 28. Seksterniony 1-27. Kwaternion 28 bez $1 \mathrm{k}$. Kustosze liczbowe na margınesach górnych 1 dolnych.

Filigrany: orzeł dwugłowy z koroną i literą $\mathrm{N} u$ dołu, k. 323.

Oprawa płsk. cıelęcy. Papıer czerpany klajstrowy, prążkowany. Grzbiet później zamalowany farbą olejną na kolor jasno-popielaty. Szycie na 3 sznurki. Jeden rzemyk do wıązanıa, drugıego brak. 
Proweniencja: Biblioteka OO. Kapucynów w Rozwadowie. Pieczątka olkrągła na wyklejkach. Sygn.: II i 358.

R 4. Eac. I pot. XVIII w. $21.5 \times 18 \mathrm{~cm}, K, 372$. Opr. płsk. wsp.

,Theologia speculativa".

Inc.: k. 2: „De gratia, iustificatione et merito. Praefatio. Tractatus: hic X Sanctae Romanae Ecclesiae dicta et scripta sunt. Amen", k. 371v.

Ksıęga ta jest dalszym ciagiem kodeksu oznaczonego sygn. 358. Nie posıada karty tytułowej. Karty niezapisane: 107v, 108, 109, 336-341v. K. 39 oddarta. $\mathrm{Na}$ margınesach numery paragrafów. Podkreślenia w tekścıe. Dukt pisma lukowaty.

Shładki: 61. Binion 61. Ternion 60. Pozostałe seksterniony. Kustosze liczbowe na marginesach dolnych. Sa one dalszym clągiem kustoszy z woluminu nr 358.

Filigrany: orzeł dwugłowy z koroną, k. 339, 341. Tarcza herbowa, k. 1.

Oprawa płsk. cielęcy. Papier czerpany klajstrowy. Grzbiet późnıej zamalowany farbą olejną na kolor jasno-popielaty. Szycie na 3 sznurki. Dwa. rzemykı skórzane do zawiązywanı.

Proweniencja: Bibjoteka OO. Kapucynów w Rozwadowie. Pieczątka okrągła na wyklejkach. Sygn.: 357. Liczba ta blędnie uzyta, ponieważ tom ten jest dalszym ciagiem woluminu oznaczonego $\mathrm{nr} 358$.

R 5. Łac. $1758.19 .5 \times 16 \mathrm{~cm}$. K. 103. Opr. sk. wsp.

1. k. 3-64. "Theologia universa, speculativa, moralis, polemica speculativa, de Deo, angelis, incarnatione etc. Mormalis cum corollariis, casuum conscientiae et directorio, polemica exhibens doctrinam acatholicam, obiectiones eorum monitorium ad sacerdotem sacris fungentem ministeriis qua tertia editione auctior auctore R. P. Angelino Brinckmann Ord[inis] S. Franc[isci] FF. Minor[um] Recoll[ectorum] lectore iubilato, Provinciae Thuringiae S. Elisabethae ministro provinciali. Wetzlariae typis 1733. Conscripta anno 1758 Lubartoviae".

Inc.: k. 5: „Quid sit theologia et quotuplex $\mathrm{X}$ utrumque sit contra charitatem, fol.":, k. 64.

2. k. 65-103. "Controversiae fidei principaliores sive in materia fidei doctrina acatholica, doctrina catholica, obiectiones acatholicae. Doctrina acatholica falsa et respuenda, catholica vera et tenenda, obiectiones insufficientes et solidae quae pridem privato discipulorum usui, publicaeque omnium utilitati, nunc altera editione sub approbationibus et censuris prioris dedit F. Angelinus Brinckmann Ord. S. Franc. FF. Min. Recoll. s. s. theologiae lector iubilatus, Provinciae Thuringiae S. Elisabethae minister provincialis actualis. Wetzlaria typis anno 1732. Haec theologia est approbata in Fuldensi dioecesi ab ordinario a theologis et maioribus".

Inc.: k. 64: „Ad lectorem. Scire tuum nihil est $\mathrm{X}$ et pendet a Summo Pontifice", k. 103.

Kodeks pisany jedną ręką $\mathrm{z}$ wyjątkiêm k. 2, 101v, 102, 103. Paginacja oryginalna: nlb. 8, 99; nlb. 2; 61, nlb. 14. Karty niezapisane: k. 1, 64v, 103v. 
Liczne podkreślenia w tekście. Indeksy: $k$. 97-101v. Na $k$. $3 \mathrm{v}$ herb opata benedyktyńskiego z Fuldy, Adolfa de Dalenborg.

Składkı: 14. 11 ma 2 k. Binion 1. Pozostałe kwaterniony.

Filigrany: herb z rybą 1 dwoma krzyżami na górze $w$ zdobniku, k. 1, 4. Matka Boska z Dzıecıątkıem i inıcjałamı C M u dołu, k. 99.

Oprawa w sk. crelęcą, barwioną na brązowo ze śladami tłoczeń linearnych na cıemno. Slady rzemyków do wıązania. Wyklejka frontowa - ślady papıeru ręcznego z motywem grzebieniowym w kolorach czerwonym 1 niebieskim, natomiast na tylnej papier $\mathrm{w}$ desenıe prasowane o motywach liściastych.

Proweniencja: 1. Klasztor OO. Kapucynów w Lubbartowie.

2. Biblioteka OO. Kapucynów w Razw adowie. Pieczątkai okrągła, k. 1, 103. Sygn.: 44.

R 6. Łac. I poł. XIX w. $22.5 \times 18.5 \mathrm{~cm}$. K. 65. Opr. brosz. wsp.

„Dogmaticae generalis par's I et $\mathrm{IT}^{\prime \prime}$.

Inc.: k. 1: „Tota doctrina, quam tradituri sumus $\mathrm{X}$ et Paulus hoc rationis postulatum confir...", k. 65 .

Kodeks bez końca. Składa się z kilku gatunków siwego papieru czer. panego, prążkowanego. Glosy marginalne wykonane atramentem i ołówkiem. Podkreślenia $w$ tekście pod koniec czerwonym atramentem. Na margınesach olówkiem zaznaczono nazwıska słuchaczy teologii np. Michna, Solskı, k. 7; Raczek k. 9; Szczerbiński k. 15v; Weiss k. 18 itd.

Składkı: 16 bınionów. Kustosze liczbowe w górnym margınesıe.

Filigrany: kraj: K L Morau, k. 13, 28. Nazwiska: J Weıs, k. 22; J Müller, k. 32 ; Leiben, k. 4.

Oprawa broszurowa. Papier czerpany gruby, sıwy, początek XIX w.

Proweniencjia: 1. A. Boczarski, alumn Sem. Duch. w Przemyślu.

2. Biblioteka OO. Kapucynów w Rozwadowie. Pieczątka akrągła na wyklejkach.

R. 7. Eac. I pot. XIX w. $22.5 \times 19 \mathrm{~cm}$. K. 67. Opr. brosz. wsp.

„Dogmaticae generalis pars III et IV. A. Boczarski” ${ }^{109}$.

Inc.: k. 1: "Ut omne obsequium nostrum sit rationabile $\mathrm{X}$ ad dogmaticam specialem transimus. Finis...", k. 67.

Rękopis jest dalszym ciągiem skryptu teologicznego $\mathrm{nr} R$ 6. Liczne podkreślenıa atramentem, często czerwonym. Glosy margınalne.

Składki: 8. Kwaterniony 1-7. Kwinternion 8. Kustosze liczbowe od nr 17.

Filigrany: miejscowość Karlsthal, k. 5. Nazwısko: J Müller k. 5. Kraj: C Morau, k. 63.

Oprawa broszurowa z klejonego papieru czerpanego, siwego.

Proweniencja: 1. Andrzej Boczarski, alumn Sem. Duch. w Przemyślu.

2. Biblioteka OO. Kapucynów w Rozwadowie. Pieczątka okragla na wyklejkach.

TEOLOGIA MORALNA

R. 8. Eac. 1747. $20 \times 16.5 \mathrm{~cm} . K .167$. Opr. brosz. wsp.

"Librorum de theologicis disciplinis thomus IV. In quo traduntur legum praescriptiones, humanorumque officiorum praecepta".

${ }_{109}$ Ur. 1819, wyśw, 1843, zm. 18 XI 1850 w suszycy w aiec. przemyskiej. - Directorium divinı officii et schematismus clerı dioec. rit. lat. Premisliensis pro a. 1851. Premisliae 1851 s. 99. 
Inc.: k. 1: „De legibus, quae humanos mores dirigunt et coercent $X$ inebriari vino scelus est, nefarium, detestabile, atque turpissimum", k. $165 \mathrm{v}$.

Kodeks wykonany przez o. Erazma Bartolta, augustianina $z$ konwentu św. Katarzyny w Krakowı. Paginacja oryginalna: 334, nlb. 10. Karty niezapisane: $117 \mathrm{v}, 166,167$. Rzadkie glosy marginalne. Na wklejkach zapiski o treści filozoficznej (logika). „Propositiones“, k. 163-165.

Skladki: 14. Kwinternion 1. Pozostałe seksterniony lecz 14 bez $1 \mathrm{k}$. Kustosze liczbowe.

Filigrany: mężczyzna z kielichem, niewıasta z bukietem kwiatów, ponad nımı napis: Egendorff, k. 2, 7 .

Oprawa broszurowa. Grzbiet - papıer barwiony na żółto. obciąnięty papierem czerpanym barwıonym na czerwono. Szycie na 3 sznurki. Grzbiet podniszczony.

Proweniencja: 1. O. Erazm Bartolt, augustianin.

2. „Fr. Romualdus Siekacz[ynensis] fillius Constantii Crasnostav[iensis] hunc librum "donavit pro Bibliotheca". Napis na wyklejce frontowej.

3. Biblioteka OO. Kapucynów w Rozwadowie. Pieczątka okrągła na wyklejkach. Sygn.: $40 ; 150$.

R 9. Łac. I pot. XVIII w. $22.5 \times 19 \mathrm{~cm}$. K. 433. Opr. ptsk. wsp.

Theologia moralis.

Inc.: k. 1: „Sacro sancta theologiae doctrina magno $\mathrm{X}$ et conciliorum S. Romanae Ecclesiae subiicio", k. 433.

Treść: "Tractatus V de beatitudine hominıs et actibus humanis“, k. 1. „Tractatus de virtutibus moralibus, vitiis et peccatis", k. 113. „Tractatus de legibus“, k. 177. „Tractatus de iure et iustitia“, k. 217. „Tractatus de sacramentis in genere, de aliquibus in specie", k. 279.

Brak karty tytułowej. Kodeks powstał w czeskiej prowincji kapucynów, k. 340. Karty niezapisane: 175v, 176, 215, 216, 386v, 387, 389, 390, 430v, 431-433. Na marginesach numery paragrafów. Rysunk1: k. 410: ,arbor consanguinitatis" o wymiarach $43 \times 38 \mathrm{~cm}$; k. 413: ,,arbor cognationis spiritualis" o wym. $34.5 \times 21.5 \mathrm{~cm}$; k. 416: ,arbor cognationis legalis" o wym. $34.5 \times 21 \mathrm{~cm}$; k. 420 : ,arbor affinitatis o wym. $35 \times 21.5 \mathrm{~cm}$.

Składki: 44. Terniony 18, 44. Pozostałe kwaterniony.

Filigrany: herb z korona, pod herbem serduszko, po obydwóch jego bokach inicjały GR, k. 387, 389. Matka Boska z Dzieciątkiem w otoku ornamentalnym, wyklejka.

Oprawa płsk. c1elęcy barwiony na brązowo, tektura sklejana ze starej makulatury (widoczne pismo gotyckie niemieckie).

Proweniencja: Biblioteka OO. Kapucynów w Rozwadowie. Pieczątka okrągła na wyklejce frontowej i k. 433. Sygn.: 25.

R. 10. Łac., pol. 1760. $18.5 \times 15.5 \mathrm{~cm} . K .86$. Opr. pt. wsp.

1. k. $1-33 \mathrm{v}$. „Liber difficultates quasdam complectens theologicas multum [continens] in oppugnationibus in varia materia redactus in hanc normam Lublini et conscriptus per F. Amandum Capucinum pro tunc theologiae lectorem anno Domini 1760 die 29 januarii". 
Inc.: k. 1v: „Quod theologia sit proprie scientia, dices $\mathrm{X}$ fuisset innocens sed posse condemnatus", k. 33v.

2. k. $34 \mathrm{v}-86 \mathrm{v}$ : „Conciones aliquae pro commoditate viae concionatoris scriptae Lubartoviae 1765 a F. Amando Cap. concionatore pro tunc dominicali".

Inc.: k. 35: "Concio pro festo Nativitatis Domini X mówi Bóg, bom ja od pieluszek zawsze", k. 86v.

Kodeks napisał o. Amand Kuczera ${ }^{10}$, kapucyn, w Lublinie 1 Lubartowie. Wstawka na $k$. $32 \mathrm{v}-34 \mathrm{v}$ pochodzı zapewne od o. Aleksandra Drabka, późniejszego długoletnıego przełożonego prowincji galicyjskiej. Od niego również pochodzı napıs na wyklejce tylnej: „Nasz Jegiełło zbił Kozaki(!), 1 ten Krupa chce być takı. Nie susz głowy ty nieboże, Krupa jagło być nie może". Tytuł umieszczony na wyklejce frontowej. Karty nıezapısane: 34r, $58,40 \mathrm{v}, 41,47 \mathrm{v}, 48$. Na marginesach numery paragrafów. Blok rękopisu przełamany między k. 69 a 70 . Częściowo zniszczony.

Składki: 11. Biniony 8,10 . Terniony $4+1 \mathrm{k}$. doklejona, 9. Kwinterniony 1,6 bez $4 \mathrm{k}$., 11 bez $3 \mathrm{k}$. Seksterniony 2, 3, 5 bez $1 \mathrm{k}$. Okternion 7 bez $5 \mathrm{k}$.

Filigrany: Matka Boska $\mathrm{z}$ Dzieciatkiem $\mathrm{w}$ koronach $\mathrm{w}$ otoku promienı, k. 34. Inicjały G A, k. 16, 17. Tarcza herbowa $z$ inicjałami u dołu A I, k. 59, 64. Stylizowane drzewo z inicjałami u spodu, P SH, k. 4.

Oprawa broszurowa obciągnięta płótnem żaglowym malowanym na czarno.

Proweniencja: 1. O. Amand Kuczera, Czech.

2. Biblioteka OO. Kapucynów w Rozwadowie. Pieczątka okrągła, k. 2, wyklejka tylna.

R 11. Łac. $1763-1774.21 .5 \times 16.5 \mathrm{~cm}$. K. 126. Opr. płperg. wsp.

1. k. 2-30v. "Compendium totius theologiae moralis complectens partes quatuor in suas figuras divisas. Collectas ex praecipuis huius aevi doctoribus praesertim vero ex P. Gervasio Brisacensi Capucino 1763 anno. Pars prima complectens figuras ne actibus humanis, peccatis et legibus". Dodatek inną ręką: „Fr. Caietanus Cap. indig[nus] Mp."

Inc.: k. 3: „Papae et summo poenitentiario respectu $\mathrm{X}$ adiunctam detractionem iniustam et gravem", k. 30 .

2. k. 31-55. „Compendii theologiae moralis pars secunda complectens figuras de iure et triplici iustitia scilicet vindicativa, cumulativa et distributiva“".

Inc.: k. 31v: „Pro lege naturali, divina aut humana $\mathrm{X}$ an gaudeat asyllo, episcopi est decidere", k. 55.

3. k. 56-82. "Compendii theologiae moralis pars 3tia complectens figuras de septem sacramentis novae legis collectals ex praecipuis huius aevi doctoribus praesertim vero ex P. Gervasio Brisacensi Capucino".

Inc.: k. 57: „Baptismus cuius finis est tollere originale $\mathrm{X}$ ex delicto sed ex defectu natalium", k. 82.

110 Ur. 29 V i733, do zak. wstąpil 1750, zm. 13 IV 1795 w Rozwadowie, - CPP nr 137; Mortuologium, Jw. 
4. k. 83-96. „Compendii theologiae moralis pars quarta complectens figuras de censuris, irregularitatibus ac statu religionis in genere nec non Fratrum Minorum in specie".

Inc.: k. 83v: „Ut peccatum absolute perfectum sit $\mathrm{X}$ perpetua si non sit superflua", k. 96.

Przy końcu kodeksu dodano: "Carmina Catonis", k. 98v. „Casus conscientiae resoluti 1763 anno“, k. 99-108v. „Dubia ad seraphicam regulam resoluta“, k. 115-115v. „Brevis et elegans methodus rite concionandi", k. 116-125. Series Reverendissimorum ministrorum generalium reformationis Capucinicae", k. 126. „Conventus Provinciae Styriaec, k. 126.

Szkoła: Studium domesticum kapucynów w Olesku. Lektor: o. Kajetan Cygler.

Paginacja oryginalna podwójna. w górnym marginesie; 55 , nlb. 1; 48, nlb. 1; 47, nlb. 1; 27; dalej brak liczbowania stron. $\mathrm{Na}$ dolnym marginesie paginacja c1agła od s. 1-176, dalej brak paginowania. Sp1s treścı: k. 97-98. Poszczególne części rękopısu oddzielone uszkamı na brzegu bocznym. Na gornym margınesie tytuły bieżące omawianych zagadnień. Liczne glosy marginalne. Kodeks od k. 99 do końca wykonany inną ręką. K. 96v: „Examen moralıum feci Flumine in Dalmatıa die 20 augusti 1766 anno". Rysunkı: k. 74: ,arbor consanguinitatıs" 1 k. 76: ,arbor affinitatis", wykonane żółtym kolorem. Zdobniki rękopisu: k. 48: podwójne koło, k. 50, owal z dwóch splecionych kół, k. 56, kompozycja roślınno-kwiatowa stylizowana w kolorze żółtym 1 jasno-fioletowym, k. 73, dwa trójkąty $\mathrm{z}$ wahadełkrem, k. 125, rozetka $\mathrm{z}$ herbem Potockich Pilawa. Inskrypcje: $\mathrm{k}$. 2v: „Nb. hoc compendium fuit primitus inventum per certum P. Joachimum Provinciae Styriae alumnum, quod dein a tota ferme Provincia acceptatum, novissime a P. Caletano Plocens1 ss. theolograe lectore emendatum et auctum fuit nobisque suls discipulis ad describendum traditum. 1763 anno".

Składki: 11. Ternion 10. Kwinterniony 1, 3, 5, 6, 7, 11. Septentriony 2, 4. Seksterniony 8, 9.

Filıgrany: inicjały A S, k. 75. Na wyklejce napıs: Gretz.

Oprawa półperg. w tekturę miękką. Papier okładki i wewnętrzna wyklejka klajstrowa. Grzbiet 1 rog1 pergaminowe.

Proweniencja: 1. O. Kajetan Cygler, kapucyn.

2. Biblioteka OO. Kapucynów w Rozwadowie. Pieczątka akrągła na wyklejkach. Sygn.: 313.

R 12. Eac. $1763-1774.24 \times 1.9 \mathrm{~cm}$. K. 96. Opr. ptsk. wsp.

1. k. 1-29. "Compendium totius theologiae moralis complectens partes quatuor in suas figuras divisas, collectas ex praecipuis huius aevi doctoribus praesertim ex P. Gervasio Brisacensi Capucino anino 1763. Pars prima complectens figuras de actibus humanis, peccatis et legibus..." Dopisek inną ręką: „Haec theologia descripta est per F. Paulum Apostolum theologiae studentem accomodata ab AVP. Caietano pro tunc magistro novitiorum ac superiore Olescensi anno 1774". 
Inc.: k. 2: „Papae et summo poenitentiario respectu $\mathrm{X}$ adiunctam detractionem iniustam et gravem", k. 29.

2. k. 30-54. "Compendii theologiae moralis pars secunda complectens figuras de iure et triplici iustitia scilicet vindicativa, cumulativa et distributiva".

Inc.: k. 30v: „Pro lege naturali, divina aut humana $\mathrm{X}$ gaudeat asyllo, episcopi est decidere", k. 54.

3. k. 55-81. „Compendii theologiae moralis pars tertila complectens figuras de septem sacramentis novae legis collectas ex praecipuis huius aevi doctoribus praesertim vero ex P. Gervasio Brisacensi Capucino".

Inc.: k. 56: „Baptismus cuius finis est tollere originale $\mathrm{X}$ ex delicto sed ex defectu natalium", k. 81 .

4. k. 82-95. „Compendii theologiae moralis pars quarta complectens figuras de censuris, irregularitatibus ac statu religionis in genere nec non Fratrum Minorum in specie".

Inc.: k. 82v: "Ut peccatum ob quod fertur $\mathrm{X}$ talia si non sit superflua", k. 95 .

Szkoła: Studium domestıcum kapucynów w Olesku. Lektor: o. Kajetan Cygler. Skryptor: br. Paweł Klimkıewicz ${ }^{111}$.

Paginacja orygınalna: 55, nlb. $1 ; 48$, nlb. $1 ; 34 ; 27$. Każda część rozprawy jest oddzielnie pagınowana. Karty niezapisane: 1v, 73, 75, 95v, 96. Na marginesie numery paragrafów. Rzadkie glosy marginalne.

Składki: 12 kwaternionów.

Filigrany: tarcza herbowa $\mathrm{z}$ koroną, pod herbem inicjały G R, k. 96 . Napis: Vander Liev, k. 46, 54. Na wyklejce frontowej korona dziewięciopałkowa $\mathrm{z}$ krzyżem $\mathrm{w}$ środku, poniżej duże inıcjały $\mathrm{J} \mathrm{T}$.

Oprawa w płsk. cielęcy i papıer czerpany klajstrowy. Brzegi nakrapiane na czerwono.

Proweniencja: 1. „Fr. Paulus Apostolus, Capucinus", k. 1.

2. Biblioteka OO. Kapucynów w Rozwadowie. Pieczattka okragła na wyklejkach.

R 13. Łac. $1767.20 .5 \times 16 \mathrm{~cm}$. K. 394. Opr. ptsk. wsp.

„Arcana s.s. theologiae universae positivo dogmatico scholasticae iuxta mentem Ioannis Duns Scoti Subtilis Marianique Doctoris elucidata per me indignum Fr. Vitum Litomisliensem pro tunc lectorem". Dopisek inną ręką: „Dictata Olescae ad S. Iosephum Sponsum B. V. Mariae die 25 augusti anno $1767^{\prime \prime}$.

Inc.: k. 2: „In triennali philosophiae cursu mentis oculo $\mathrm{X}$ talis non potest sperare beatitudinem", k. $293 \mathrm{v}$.

Szkoła: Studium domesticum kapucynów w Olesku. Lektor: o. Wit Syrowy.

Pagınacja oryginalna: 762, nlb. 21. Spis treśc1: k. 383-393. Na marg1nesach numery paragrafów. Tytuł ujęty w podwójną szeroką ramkę, w której znajduje się ornament o motywach roślinnych. W czterech wewnętrznych

111 Ur. 1 V 1749, do zak. wstapił 1767, zm, 3 X $1810 \mathrm{w}$ Warszawie. - CPP nr 333. 
narożnikach ramki napıs: „Anno Dominı 1767 die 18 maii“. Na odwrocie karty tytułowej zlota myśl: "Scire decet, sed scire pie, nam scire superbe mors est, vivere vis, scire superbe cave“. Pod napisem ornament o motywach roślınnych i kwiatowych. Inskrypcja: k. 323: „Subierunt examen ex hac universa theologia Leopoli anno 1771 die 25 aprilis". W górnym marginesie każda strona znaczona krzyżykiem.

Składk1: 33. Kwinternion 2. Pozostałe seksterniony.

Filıgrany: orzel $\mathrm{z}$ napisem Zoon, k. 293. Napis: I Hinec, k. 387. Matka Boska $\mathrm{z}$ Dzıeciątkıem w otoku promieni, na wyklejce tylnej.

Oprawa w płsk. cıelęcy barwiony na brązowo. Grzbiet i okładki zniszczone. Brzegi nakrapiane na niebiesko.

Proweniencja: 1. O. Wit Syrowy, Czech.

2. Biblioteka OO. Kapucynów w Rozwadowie. Pieczątka okrągła na wyklejkach. Sygn.: 26.

R 14. Eac. 1767. $20.5 \times 16 \mathrm{~cm}$. K. 376. Opr. ptsk. wsp.

„Arcana s.s. theologiae universae positivo dogmatico scholasticae iuxta mentem Ioannis Duns Scoti Subtilis Marianique Doctoris elucidata per A. V. P. Vitum Litomisliensem pro tunc lectorem theologiae dignissimum. Descripta a me Fr. Lucio Cap. indigno in Con[ventu] nostro Olescensi. Anno Domini 1767 die..."

Inc.: k. 2: „In triennali philosophiae cursu mentis oculo X S. Romane Ecclesiae corrigendum subiicimus" k. 376.

Szkoła: Studium domesticum kapucynów w Olesku. Lektor: o. Wit Syrowy, Czech. Skryptor: o. Lucjusz Velle ${ }^{112}$, Morawianin.

$\mathrm{Na}$ marginesach numery paragrafów. Inicjały pięknie zdobione. Karta tytułowa wypisana starannie brązowym atramentem. Na odwrocie sentencja: „Scire decet, sed scire pie, nam scire superbe, mors est. Vivere vis, scire superbe cave". Wokoło tytułów poszczególnych traktatów piękne floratury. Rysunk1: k. 203v: „arbor consanguinitatis“, k. 204: „cognatio legalis", k. 204: "Cognatio spiritualis".

Składki: 36. Binıon 29. Ternıony 22, 23. Kwaterniony 10, 17-21, 27, 28, 33. Kwinternion 14. Septentrion 11. Pozostałe seksterniony.

Filigrany: napis Zonen, k. 2; I Honen, k. 2. Fragment filigranu z tarczą herbową i datą 1746, wyklejka frontowa.

Oprawa w płsk. crelęcy barwiony i papier czerpany, barwiony na. brązowo. Brzegi nakrapiane na niebiesko.

Proweniencja: 1. O. Lucjusz Velle, kapucyn.

2. Biblioteka OO. Kapucynów w Rozwadowie. Sygn.: 350.

R 15. Eac. II pot. XVIII w. $21 \times 17.5 \mathrm{~cm}$. K. 261. Opr. brosz. wsp.

„Arcana ss. theologiae universae iuxta mentem Subtilis (w oryginale subtilium) Marianique Doctoris Ioannis Duns Scoti methodo scholastica elucidata".

Inc.: k. 2: „Inscrutabilia satis sacro-sanctae theologiae aroana $\mathrm{X}$ repraesentas versus circa hoc vel haec", k. 261v.

112 Ur. 29 VIII 1737, do zak. wstąpif 1762, zm. 1 X 1812 w Rozwadowie. - CPP nr 297; Mor-tuologium, JW, 
Szkola: prawdopodobnie studium domesticum kapucynów w Olesku.

Kodeks bez końca. Karty niezapisane: 17,-18, 19, 168v, 169, 213v, $213 \mathrm{a}$. $214,215,216,239,240,244 \mathrm{v}, 245,246,247,248$. Na marginesach numery paragrafów. Bardzo rzadkie glosy, jak równieź podkreślenia $w$ tekście.

Składki: 24. 24 ma 2 k. Biniony 6, 7. Kwaterniony 2, 22. Kwinterniony 1, 8, 12, 14, 23. Seksterniony $3-5,10,16,20,21$. Septentriony 9, 11, 13, 15. Okterniony 17-19.

Filigrany: Matka Boska z Dzieciątkıem w otoku promieni, k. 2. Tarcza herbowa $z$ napisem $u$ dołu: Iacob LB, k. 19. Inıcjały I A, k. 244.

Oprawa broszurowa w tekturę. Brak tylnej okładki. Pozostała oprawa bardzo zniszczona. Szycie na 2 paski pergaminowe.

Proweniencja: Biblioteka OO. Kapucynów w Rozwadowie. Pieczątka okrągła na wylkllejce frontowej i s. 261v. Sygn.: 26.

R 16. Eac. 1798. $18 \times 11.5 \mathrm{~cm}$. K. 444. Opr. sk. wsp.

"Compendium theologiae moralis. Ex. R. P. A. Reiffenstuel aliisve recentissimis collectum per A. R. P. Felicem a Cantalicio ${ }^{113}$ Capucinum sacrae theologiae lectorem anno... 1798 diebus ianuarii. In Conventu nostro Vetero Constantinoviensi sub titulo Sancti Ioannis Baptistae".

Inc.: k. 4: „Prolegomena. Quid est theologia moralis $\mathrm{X}$ ac fidelibus continuum obsequium", k. 433.

Blok kodeksu składa się z papieru czerpanego prążkowanego, siwego. Reklamanty.

Składkı: 55 kwaternionów. Kustosze liczbowe.

Filigrany: fragmenty filigranów niezidentyfikowane.

Oprawa w sk. cielęcą ściemnioną. $\mathrm{Na}$ okładkach podwójna ramka tłoczona na ślepo. Szycie na 2 sznurki.

Proweniencja: 1. O. Feliks Podfilipski, kapucyn.

2. Biblioteka OO. Kapucynów w Rozwadowie. Pieczątka okrągla na wykllejkach.

R 17. Eac., pol. II poł. XVIII w. $16.5 \times 10 \mathrm{~cm}$. K. 149. Opr. sk. wsp. ,Theologia moralis. Epitome Benedicti 14 [?]“.

Inc.: k. 1: "Compendiosa tractatuum monalium constrictio. Tractatus $\mathrm{X}$ verum si adhuc perseverat metus scandalorum", k. $149 \mathrm{v}$.

Pierwsza ręka zapısała do k. 124. Dalej tekst pochodzi od o. Amanda Kuczery, Czecha, z r. 1769. Numery paragrafów na marginesach. Glosy margınalne. Pagina żywa biegnie przez cały rękopıs. Płócienna zakładka.

Składk1: 19. Ternıon 1. Kwinternion 2. Pozostałe kwaterniony.

Filigrany: fragmenty filigranów niezidentyfikowane.

Oprawa w całą sk. cielęcą barwioną na brązowo. $\mathrm{Na}$ okładkach rameczka tloczona linıą prostą na ciemno. Szycie na 4 sznurkı.

Proweniencja: 1. O. Amand Kuczera, kapucyn.

2. Biblioteka OO. Kapucynów w Rozwadowie. Pieczątka okrągła na wyklejkach.

113 Ur. 9 XIr 1760, do zak. wstapił 1783, zm. 28 II 1811 w Winnicy. - CPP nr 412; Mortuologium pođaje rok śmiercl 1812. 


\section{TEOLOGIA PASTORALNA}

R 18. Pol. 1830. $24.5 \times 20 \mathrm{~cm}$. K. 146. Opr. brosz. wsp.

„Skrypta theologii pastoralnej $\mathrm{z}$ autorów najnowszych najdokładniej zebrane, tradowane w Lwowie 1830. X. Józefa Krzysikiewricza, kapucyna. Ofiaruje do biblioteki rozwadowskiego konwentu".

Inc.: k. 1: „Krótki rys religijnego nauczania przed Chrystusem X które na niego sakr[ament] mał[żeństwa] wkłada, zaniedbać", k. 146.

Szkoła: Studium teologıczne dla zakonników we Lwowie. Skryptor: o. Józef Krzysikiewıcz.

Blok rękopısu składa się z kilku gatunków papreru czerpanego, prążkowanego. Papier siwy od k. 76-83, 104-146.

Składkı: 29. 8 ma 2 k. Septentriony 4, 27, 28, 29. Pozostałe biniony. Kustosze literowe do k. 32, później liczbowe.

Filıgrany: napis: Schonberg $\mathrm{K}$ W, k. 12. Fragment gwiazdy z literą $\mathrm{M}$, k. 76. Litera A, k. 134 .

Oprawa broszurowa ze sklejonego papieru czerpanego, siwego.

Proweniencja: 1. O. Józef Krzysilkjewicz.

2. Biblioteka OO. Kapucynów w Rozwadowie. Pieczątka okrągła na wyklejkach.

\section{HOMILETYKA}

R 19. Pol., lac. II pot. XVIII w. $23 \times 18.5 \mathrm{~cm}$. K. 138. Opr. sk. wsp. Kazania.

Inc.: k. 1: "Thema, Qui ex Deo est, verba Dei audit. Joannis 8vo. Tryumfuj po części X czyliż mu odmówiemy powinnej czci i chwały", k. $138 \mathrm{v}$.

Kodeks jest dzielem o. Tomasza Nowiszewskiego ${ }^{114}$, kapucyna.

Tytuły kazań i motta w jęz. łac. Bez tytułu. Reklamanty. Karty niezapisane: $12 \mathrm{v}, 24 \mathrm{v}, 44 \mathrm{v}, 62 \mathrm{v}, 108,114$. Przekreślenıa tekstu na k. 20v, 21r. $\mathrm{Na}$ wyklejce frontowej podpis: „fr. Thomae Capucini“. $\mathrm{Na}$ wyklejkach $1 \mathrm{k} .138 \mathrm{v}$ szereg nazwısk z parafii Rozwadów z lat 1816, 1817, liczba wyspowıadanych osób przez jednego z kapucynów oraz dwie recepty na ,balsamum vitae".

Składki: 27. 5, 23, po 2 k. Biniony 1, 3, 6-10, 17, 18, 20, 22, 25, 26. Terniony 11, 12, 14, 19, 21, 24. Kwaterniony 2, 4, 13, 16. Kwinternion 15. Seksternion $27 \mathrm{bez} 2 \mathrm{k}$. Kustosze liczbowe.

Filigrany: tarcza herbowa $\mathrm{z}$ koroną pıęciopałkową, pod herbem nazwisko: C \& I Honig, k. 124, 138.

Oprawa w sk. cielęcą barwioną na brązowo. Tektura szmaciana. Szycie na 3 sznurkı. Brzeg1 marmurkowane na niebiesko.

Proweniencia: 1. O.Tomasz, kapucyn.

2. Biblioteka OO. Kapucynów w Rozwadowie. Pieczątka okrągła na wyklejkach. Sygn.: 109.

R 20. Pol., lac. II pot. XVIII w. $21.5 \times 17.5 \mathrm{~cm}$. K. 115. Opr. sk. wsp. „Contiones et aliae doctrinae et exhortationes ad missiones et ad

11: Ur. 24 VIII 1741, do zak. Wstąpił 1763, zm. 1 III 1802 w Rozwadowıe. - CPP nr 311. 
iubileum servientes seu sermones sacri nihil in se continentes nisi sacrae scripturae Veteris et Novi Testamenti, doctrinas et exempla s[anctorum], vitia et virtutes hominum annunciantes".

Inc.: k. 1: „Król Królów i Pan panujących $\mathrm{X}$ kochał i zawsze był wiernym", k. 115.

Kodeks jest dziełem o. Tomasza Nowiszewskıego, kapucyna.

Tytuły kazań i motta w jęz. łac. Bez karty tytułowej. Reklamanty. Karty niezapisane: $5 \mathrm{v}, 52 \mathrm{v}, 56,60 \mathrm{v}, 73 \mathrm{v}, 79,80,105 \mathrm{v}, 115 \mathrm{v}, 116$. Kolumna tekstowa ujęta w podwójną ramke marginalna. Od k. 112 ramka nuekompletna. Dwukolumnowy tekst od k. 96-105. 2/2 k. 48 wycięte. 1/4 wyklejki tylnej wycięta. Na wyklejce tylnej zapiskı dotyczące pogrzebów parafii Rozwadów z r. 1795.

Składki: 28. 8 ma 2 k. Kwinternion 2. Pozostałe biniony. Kustosze częściowo zachowane.

Filigrany: tarcza herbowa z mała koroną i napssem: F W Dau, k. 1-50. Tarcza herbowa $\mathrm{z}$ dużą koroną, $\mathrm{k}$. 79. Inicjały GR, k. 73. Tarcza herbowa $\mathrm{z}$ dużą koroną 1 nazwiskıem: C \& P Wernner, k. 110, 111.

Oprawa $\mathrm{w}$ sk. cielęcą barwioną na brązowo. Tektura sklejana $\mathrm{z}$ makulatury. Brzeg1 marmurkowe.

Proweniencja: 1. O. Tomasz, kapucyn.

2. Biblioteka OO. Kapucynów w Rozwradowie. Pieczątka okrągła na wyklejkach. Sygn.: 18.

R 21. Pol. II pot. XIX w. $20.5 \times 16.5 \mathrm{~cm}$. K. 136. Opr. ptpt. wsp. „Notatki do kazań czerpane z różnych źródeł. Ks. Łyczkoo Jędrzej“ ${ }^{115}$. Dodana częściowa biografia autora.

Proweniencja: Bibliotelka OO. Kapucynów w Rozwadowie. Pieczątka okrągła na wyklejkach.

R 22. Pol. II pot. XIX w. $17 \times 10.5 \mathrm{~cm}$. K. 237. Opr. ptpt. wsp.

„Miesiąc Maryi przez ks. biskupa Ségur z francuskiego podług drugiego wydania na język polski przełożony".

Od k. 133 różne kazania głoszone przez o. Ksawerego Maternę ${ }^{116}$, kapucyna. Podane miejscowości i daty. Karty niezapisane: $182 \mathrm{v}-237$. Napis na k. 1: „X. Xav. Materna ex ordin[e] Capucinor[um] in Krosno“.

Proweniencja: 1. O. Ksawery IMaterna.

2. Biblioteka OO. Kapucynów w Rozwadowie. Pieczątka okrągła na wyklejkach.

\section{KATECHETYKA}

R 23. Pol. 1763. $15.5 \times 10 \mathrm{~cm}$. K. 190. Opr. ptsk. wsp. „Krótkie nauki chrześcijańskiej dla dusz krwią Chrystusowych odku-

115 Ur. 1847, wyśw. 1874, zm. 12 I 1929 w Krośnıe. - Schematismus dioec. Premısliensis. . . pro anno D. 1907 s. 106, 282; Schematismus Ordinis Minorum S. P Francisci Capuccinorum Prov. Cracoviensıs. Cracoviae 1937 s. 38 . W zakonıe przebywał w charakterze tercjarza, przyją imıę Piotra.

116 Ur. 7 VI 1855 w Haczowıe, do zak. Wstąpil 1880, zm. 6 VII 1915 w Krośnie. - Mortuologıum, JW.; Descriptio personalis provinciae Galicianae nr 8. Rkps APK. 
pionych zebranie a przez X. Michała Kroczyńskiego Pllebanal B. R.P. 1763 dnia 13 lipca przepisane".

Inc.: k. 4: „Sinite parvulos venire ad me. Mar. 10. Dopuście maluckim X nie chcę obrazić. Boże bądź milłościw etc.", k. 190v.

Reklamanty. Karty niezapisane: 1, 2, 3, 170-188.

Składki: 25. 1, 2 po $k$. Biniony 5. Terniony $3,4,6,8,10,12,14,16$. Kwinterniony $7,11,13,15$. Septentrion 25. Pozostałe kwaterniony.

Filıgrany: dwie postaci, u góry fragment napisu: Gretz, k. 1, 2. Fragment napisu: Allemo, k. 175.

Oprawa w plsk. cielęcy, barwiony na ciemno. Okladki z papieru czerpanego klajstrowego, barwionego na brązowo. Brzegi barwione na czerwono.

Proweniencja: 1. Ks. Michał Kroczyński, pleban B (?).

2. „Ex libris Rndi Val[entini] Tarkowski“. Napis na k. 3v.

3. Biblioteka OO. Kapucynów w Rozwadowie. Pieczątka okrągla na wyklejkach.

R 24. Pol. 1781-1782. $16.5 \times 10.5 \mathrm{~cm}$. K. 101, 52. Opr. ptpt. wsp. „Katechizm traidowany w Baranowie 1781/2“.

Dodane zapiski z zakresu medycyny.

Oprawa w płpł. kaliko 1 papier czerpany czarny chagrain.

Proweniencja: Bỉblioteka OO. Kapucynów w Rozwadowie. Pieczątka okrągła na wyklejkach.

R 25. Pol. 1891. $21 \times 17 \mathrm{~cm}$. K. 166. Bez opr.

„Katechetyka katolicka. Wykład księdza prof. Józefa Bielenina ${ }^{117}$. Kraków. 1891“.

Skrypt seminaryjny bez końca. k. $1,83 \mathrm{v}$.

Proweniencja: Biblioteka OO. Kapucynów w Rozwadlowie. Pieczątka okrągła,

\section{LITURGIKA}

R 26. Eac. 1677. $15.5 \times 9.5 \mathrm{~cm}$. K. 115. Opr. sk. wsp.

„Modus seu forma pulchra qualibet confessarius se circa infirmos gerere, ipsos iuvare, per exempla et sacrae scripturae testimonia variis morbis laborantes et aegrotantes consolari debeat. Conscriptus a me P. C. F. Anno 1677 Pragae".

Inc.: k. 4: „Documenta pro iuvandis infirmis. Magnum $\mathrm{X}$ mirabiles effectus contigisse, diligenter nolentes", k. 115.

Kodeks pisany dwiema rękami. Pismo pierwszej ręki do k. 101, dalej druga ręka. Paginacja oryginalna: nlb. 6,196 , nlb. 24. Na wyklejce tylnej wiersz o Matce Bożej: „Me fidel committo Tibi..."

Składk1: 15. Binıon 1. Seksternion 11. Pozostałe kwaterniony.

Filigrany: fragment niezıdentyfikowanego filigranu, k. 2.

Oprawa w sk. c1elęcą czarną, z rameczką tłoczoną na ślepo linią prostą. Grzbiet o trzech polach wykonany farba olejną i malowanym napisem. Zamknıęcıe na rzemykı z zatrzaskami. Kapitałka ręcznıe wyszywana.

117 Ur. 1850, wyśw. 187מ̉, prof. Seminarıum Nauczycielskiego w Krakowie. zm. 1923. 
Prowentencja: 1. "Libellus iste dono datus est mihi fratri Constantio ab Adm. Rndo Patre Theodulo Plagense Znoymae 1726". Napis na k. 1.

2. Bibliateka OO. Kapucynów w Rozwadowie. Pieczątika okrągła na wyłklejce frontowej i k. 115v. Sygn.: U - 581; 154.

R 27. Łac., pol. II pot. XVII w. $15 \times 9.5 \mathrm{~cm}$. K. 323. Opr. sk. wsp. „Observationes lythurgicae, R. P. Drużbicki ${ }^{118}$ Soc. Jesu".

Inc.: k. 1: „Praxis oblationis quadruplicis fructus sacrificii $X$ na poratowanie dusz w czyścu będących", k. 323 .

Reklamanty. Karty niezapisane: 93v, 308v, 309, 323v. Rzadkie glosy. Blok rękopisu $w$ brzegu górnym i dolnym, łạcznie $z$ ostatnımi kartami, bardzo uszkodzony przez powalanie inkaustem. Ostatnıe karty rozsypują się. Tekst polski od k. 321v. Zapiska na frontowej wyklejce: „Anno 1668 24 augusti R. P. Alexander Lorencowicz praepositus provincialis per Provinciam Poloniae concessit mihi P. Michaeli Sieklucki novitio tum Soc. Jesu liberationem anımae e purgatorıo pro quolibet sacro".

Składk1: trudne do przelıczenıa.

Filigrany: fragment niezıdentyfikowanego filigranu w lewym górnym rogu karty, k. 7.

Oprawa w czarną sk. cıelęcą, $z$ ramką tłoczoną na ciemno $w$ formie bordiurk1 $\mathrm{z}$ motywem liści. $\mathrm{Na}$ frontowej okładce postać Ukrzyżowanego Chrystusa z klęczącą Matką Bozą, na tylnej postać Matkı Boskiej z Dziecratkiem Jezus. Na grzbiecie trzy pola zamalowane na kolor jasno popielaty, w obwódce czerwonej. Brzegi ręcznie złocone.

Prowemiencja: 1. O. Michał Sieklucki T. J.

2. „Ex Catalogo Librorum Domus Professae Crac. Soc. Jesu“. Napis na wyklejce frontawej.

3. Biblioteka OO. Kapucynów w Rozwadowie. Pieczątka okrągła na wydklejkach. Sygn.: $\mathrm{T}-552 ; 345$.

R 28. Łac. II pot. XVIII w. $16 \times 9.5 \mathrm{~cm}$. K. 39. Opr. plsis. wsp.

„Officia quaedam novissima sanctorum".

Inc.: k. 1: „Die XIV ianuarii in festo Beati Bernandi X perpetuo inhaerere valeamus. Per Dominum nostrum": $k, 39 \mathrm{v}$.

Reklamanty. Kodeks rubrykowany. Pagina żywa rubrykowana.

Składki: 5 kwaternionów. Kustosze literowe: A-D.

Filıgrany: fragment nıezidentyfikowanego filigranu $\mathrm{w}$ górnym margınesie karty.

Oprawa w płsk. cıelęcy, ściemniony. Papıer klajstrowy ściemniony. Szycie na. 3 sznurki. Brzegi czerwone.

Proweniencja: 1. "Ad usum Fr. Joannis Nepo[muceni] Capucini"“. Napis na wyklejce frontowej.

2. Bibliatelka OO. Kapucynów w Rozwadowie. Pieczątka olkrąła na wyklejkach.

R 29. Łac. II pot. XVIII w. $16.5 \times 10 \mathrm{~cm}$. K. 71. Opr. perg. wsp. „Liber novitiorum".

118 B a c ker-Som m e r vog e 1 I $851-852$; Ks. J. B r ow n, Jw., s. 160-164; Enc. Olgelbr. VII 503-505; J o che r (indeks); Estr. II 234; Pol. Stown. brogr. V 403-404 (St. Bednarski); W1. Wisłocki, Jw. nr 2383, 2518, 3296, 3287, 3527, 3528; Bp W. W ó J c 1 is, Jw. s. 314 nr 185; Ks. St. Z a f ęs k l, Jw. T. 1 s. $123,125,132,133,351,354 ;$ t. 2 s. 792 ; t. 3 s. 1259, 1262. 
Inc.: k. 2: „Sancta Maria succurre miseris, iuva X donec videamus te Deum in Sion. Amen", k. 70v.

Pierwsze słowo tytułu rubrykowane. Pod koniec tekstu blok rękopısu podniszczony. Wyklejka frontowa oderwana.

Składkı: 9. Ternion 9. Pozostałe kwaterniony.

Filigrany: fragment filıgranu w górnej częścı karty.

Oprawa pergaminowa ze śreaniowiecznego antyfonarza.

Proweniencja: Biblioteka OO. Kapucynów w Rozwadowie. Pieczątka okrągla na wyklejkach.

R 30. Eac. II pot. XVIII w. $19 \times 12 \mathrm{~cm}$. K. 73. Opr. sk. wsp.

Modlitewnik kapłańsiki.

Inc.: k. 1: Conclave VII. Pro anima poenitentiam agente $\mathrm{X}$ gaudia tecum pervenire valem. Amen $6, k$. $60 \mathrm{v}$.

Częścıowo występują reklamanty. Karty niezapisane: $64 \mathrm{v}-73$. Wykonany jeđną ręką $z$ wyjątkıem dwóch pıerwszych kart 1 melodii gregoriańskıch od k. 61-64. Rubrykowany.

Składk1: 19. 1, 16 po $2 \mathrm{k}$. Ternion 17. Kwaternion 19. Pozostałe biniony. Filigranów nie ma.

Oprawa $\mathrm{w}$ sk. cielęcą, ściemnioną, wiśnıową, z ramecżkà tłoczoną na clemno o delikatnym rysunku filigranowym, liściastym. W rogach stemple z kwıatami. Na grzbıecıe zdobniki kwiatowe. Kapitałka ręcznie wyszywana. Erzegı ręcznie złocone. Wyklejka na papıerze czerpanym na karagenie.

Prowenienoja: 1. Ks. Walenty Kwietniewicz, proboszcz rozwaldowski. Napis na wyklejce frontowej.

2. Biblioteka OO. Kapucynów w Rozwadowie. Pieczątka okrągła na wyklejkach.

R 31. Pol. II poz. XIX w. $20 \times 12.5 \mathrm{~cm}$. K. 19. Opr. ptpt. wsp.

„Modlitwy i pieśni tygadniowe dla Vtej i VIImej klasy w Jaroslawiu".

Proweniencja: Bibliateka OO. Kapucynów w Rozwadowie. Pieczątka oksrągła na wyklejce frontowej.

\section{TEOLOGIA ASCETYCZNA I MISTYCZNA}

R 32. Pol. II pot. XVII w. $20.5 \times 15.5 \mathrm{~cm}$. K. 142. Opr. sk. wsp.

Rozmyślania o drodze oczyszczającej, oświecającej i jednoczącej.

Inc.: k. 1: „Przestrogi potrzebne dla lepszego używania X wspiera miłość, pokuta przyprawuje do wesela“, k. 142v.

Kodeks bez początku 1 końca. Początkowe karty i ostatnia składka wyrwane. Reklamanty. Paginacja oryginalna: nlb. 12, 370. „Rejestr rozmyślania“, k. $3 \mathrm{v}-6 \mathrm{v}$. Rzadkıe glosy marginalne. Tytuły rozdziałów wykonane $\mathrm{w}$ formie liter drukowanych.

Składki: 36 binıonów.

Filigrany: rycerz klęczący $\mathrm{z}$ mieczem, niewiasta $\mathrm{z}$ kądzielą, inicjały, J K P; napıs: Pro Patria, k. 8, 78.

Oprawa sk. cielęca barwiona na brązowo. Na grzbiecle tłoczony stemplem zdobnik fillgranowy. Szycıe na 4 sznurki. Kapitałka ręcznie szyta. Brzegi 
nakrapiane na czerwono. Wyklejka - papier czerpany kolorowany o motywie grzebieniowym. k. $1,142 \mathrm{v}$.

Proweniencja: Biblioteka OO. Kapucynów w Rozwadowie. Pieczątka okrągła,

R 33. Pol. II pot. XVIII w. $19.5 \times 16 \mathrm{~cm}$. K. 363. Opr. sk. wsp.

Rozmyślania.

Inc.: k. 1: „Intencyje Komonii ś. czynić różne akty $\mathrm{X}$ zakonnym doczesnym żeby próżnowanie ponoszenia...", k. 363v.

Kodeks bez początku 1 końca. Pisany dwıma rękaml, pierwszą od k. $1-8 \mathrm{v}$, drugą pozostałe karty.

Składki: około 91. 1 ma $2 \mathrm{k}$. Ternion 2. Kwaternıon 3. Pozostałe bıniony.

Filigrany: Matka Boska z Dzıecıątkiem w otoku promieni, k. 1. Tarcza herbowa $\mathrm{z}$ pastorałem i krzyżem, k. 321, 324.

Oprawa w sk. cielęcą barwioną na brązowo. Szycie na 3 sznurkı ze śladami późnıej umieszczonych tasıemek do wiązania. Kapıtałka szyta. Brzegi nakrapiane na niebiesko.

Proweniencja: Biblioteka OO. Kapucynów w Rozwadowie. Pieczątka okrągła na wyklejkarch.

\section{BIBLISTYKA}

R 34. Eac. $I$ pot. $X I X$ w. $22 \times 17 \mathrm{~cm}$. K. 199. Opr. brosz. wsp.

"Introductio in libros s[acros] N[ovi] T[estamenti]".

Inc.: k. 1: ,Introductio (Isagoge) in 1[ibros] s[acros] N[ovi] T[estamenti] $X$ an serius, certo diu nequitur", k. $199 \mathrm{v}$.

Rękopis złożony $\mathrm{z}$ kilku gatunków papieru czerpanego prążkowanego, siwego. Glosy marginalne.

Składki: 56. 56 ma 2 k. Pozostałe biniony. Kustosze liczbowe z napisem: "Introductio in N[ovum] T[estamentum] specialis".

Filigrany: napıs kursywą: Kerbach, k. 2, 128. N 2, k. 56. Inicjały A S, k. 193.

Oprawa broszurowa ze sklejanego papieru czerpanego, siwego.

Proweniencja: Biblioteka OO. Kapucynów w Rozwadiowie. Pieczątka olkrągła na wyklejkach.

I 35. Eac. I poz. XIX w. $24 \times 19.5 \mathrm{~cm}$. K. 303. Opr. brosz. wsp.

"Introductio in libros s[acros] $\mathrm{N}$ [ovi] T[estamenti]“.

Inc.: k. 1: ,Introductio (Isagoge) in 1[ibros] s[acros] $\mathrm{N}$ [ovi] $\mathrm{X}$ an serius uti diu nequitur", k. 303.

Rękopis napisany prawdopodobnie przez o. Józefa Krzysikiewicza, kapucyna. Karta niezapisana: $89 \mathrm{v}$. Glosy marginalne: k. 1, 5, 6v, 12, 24v, 34, 35, $67 \mathrm{v}, 90 \mathrm{v}, 119 \mathrm{v}, 143,217 \mathrm{v}, 290,291,292 \mathrm{v}$.

Skladki: 79. 1, 2, 12, 18 po $2 \mathrm{k}$. Pozostałe biniony.

Filigrany: nazwa kraju: Morau, k. 102.

Oprawa broszurowa. Papier sklejany czerpany, siwy.

Proweniencja: 1. O. Józef Krzysikiewičs.

2. Biblioteka OO. Kapucynów w Rozwadowie. Pieczątka okrągła na wyklejkach. 


\section{PRAWO KANONICZNE}

R 36. Niem. 1741. $10 \times 7 \mathrm{~cm}$. K. 227. Opr. sk. wsp.

„Regul und Testament des seraphischen Viatters s. Francisci mitunder... schonen gristlichen(!) exercitien und andren nutzlichen Sachen. Bruder Hieronym Donner im Jahr 1741". (k. 2).

Inc.: k. 3: „Honorius Bischoff ein Diener der diner Gottes X Stern der Himmel und der Erden sterbrich". k. 217v.

Tekst pisany szwabachą jedną ręką. Autor rękopisu: br. Hieronim Donner zє Lwowa. Na karcie 1 skrócony tytul: „Die Regul und das Leben der minderen Brider (!). Der Anfang des Ordens ist schon 542 Jahr". Register: k. 222. Na odwrocie karty tytułowej nalepiony sztych wykonany we Lwowie i przedstawiający wręczenıe reguły św. Francıszkowi przez Chrystusa.

Składki: 28. Ternion 24. Oktemion 21. Pozostałe kwaterniony. Kustosze literowe.

Oprawa w sk. czarną chagrain. Grzbiet malowany farbą olejną. Szycie na 3 sznurkı. Slady rzemyków 1 zapinek. Kapitałka ręcznie wyszywana. Brzeg1 kolorowe, grzebieniowe na karagenie.

Proweniencja: 1. Br. Lileronim Donner.

2. Joannes Franciscus Brossmann. Napis na wyklejce frontowej.

3. Biblioteka OO. Kapucynów w Rczwadowie. Pileczątka okrągha, k. 1, 227. Sygn.: 354

R 37. Łac. II poł. XVIII w. $19.5 \times 15.5 \mathrm{~cm}$. K. 176. Opr. ptsk. wsp. „Expositio regulae FF. Minorum Sancti' Patris nostri Francisci Seraphici litteralis ac genuina, fundata in declarationibus Summorum Pontificum Nicolai III et Clementis V".

Inc.: k. 8: ,Ad lectorem benevolum seu F[ratres] regulam profitentes istam X semper circa custodiam Ordinis, ut Ordo custodiat vos", k. 171.

Karty niezapisane: $1-6,171 \mathrm{v}, 172-176$.

Składki: 16. Binion 1. Kwinterniony 9, 10. Septentriony 12, 14, 15. Okternion 16. Pozostałe seksterniony.

Filigrany: jeździec na koniu $\mathrm{w}$ ubranıu $\mathrm{z}$ XVII w., k. $2,3$.

Oprawa w płsk. cıelęcy barwiony na cıemno - brązowo. Brzegi nakrapiane na niebiesko.

Prowweniencja: Biblioteka OO. Kapucynów w Rozwadowwie. Pieczątka okrągla na wyklejkach. Sygn.: 35.

\section{FILOZ.OFIA SCHOLASTYCZNA}

R 38. Eac. 1713. $20 \times 14 \mathrm{~cm}$. K. 146. Opr. brosz. wsp.

"Compendium philosophiae. M. Jo[annes] N[epomucenus] Gaworski ${ }^{119}$, mpp."

Inc.: k. 2: „Praeliminarium ad doctrinam logicam de natura et proprietatibus logicae X eiusque validitate vide Busenbaum hic Nb.", k. 146.

119 Skrypt nalezy prawdopodobnie do J. N. Gaworskiego, o którym wspomma Pol. Stown. biogr. VII 320 (Al. Birkenmajer); Enc. Chelm. XIII/XIV 59; Enc. Orgelbr. IX 668; J o c h e r nl 5490. 
Treść: kodeks zawıera logikę, k. 1-22. „Compendium physicae seu scientiae naturalis", k. 22v-54. „Philosophram moralem“, k. 57-139. „Quaedam de sacramentss ordinando scienda", k. 141-146.

Szkoła: prawdopodobnie jedno $z$ kolegiów rzymskich.

Reklamanty. Karty niezapisane: Iv, 54v, 55, 56, 140, 146v. W foliowaniu opuszczono jedną kartę, którą oznaczono dodatkowo numerem 63a. Glosy marginalne: k. 1, 4v, 7, 18, 20, 24v, 26, 36, 141v-146. Kilka składek na początku i na końcu rękopısu wyciętych. Składki te prawdopodobnie nie były zapisane. Inskrypcje: k. 54: „Finitum Romae anno Domini 1713 die13tıa 8bris"; k. 139v: "Hoc opusculum philosophrae finitum Romae anno 1713 die 13 8bris".

Składki: 13. Kwaternion 5. Kwinternion 13 bez $3 \mathrm{k}$. Pozostałe seksterniony.

Filigrany: koło $z$ sześcioramienną gwıazdą $w$ środku, w centralnym kole gwiazdy litera P, ponıżej koła litera F, k. 140. Koło z kotwica w środku zakończone $w$ górze sześcioramienną gwlazdká, ponıżej krła litera $\mathrm{F}, \mathrm{k}$. $50,55,67$.

Oprawa w tekturę szmacianą, obciągniętą papıerem czerpanym.

Proweniencja: 1. J. N. Gaworski.

2. Biblioteka OO. Kapucynów w Rozwadowie. Pieczątka okrąła, k. 1, 146v. Sygn.: 39.

R 39. Eac. 1722-1724. $19 \times 15.5 \mathrm{~cm}$. K. 215. Opr. płsk. wsp.

„Arcanum naturae seu scientia naturalis ad mentem subtilissimi Doctoris Ioannis [Duns] Scoti in Conventu Calissiensi ad B. V. M. visitantem perscrutatum anno quo absconditum a saeculis in utero Virginis. apparuit arcanum $1722^{\circ}$.

Inc.: k. 4v: „Cum gaudio secundum ardior cursum quia $\mathrm{X}$ et hic labor meus cedat...", k. 211.

Szkoła: Studium domesticum francıszkanów w Kalıszu. Lektor: o. Ludwik Roman.

Karty niezapisane: 1, 2, 3, 144, 145, 146, 182v, 211v-215v. Na marg1nesach numery paragrafów. Każda strona znaczona krzyżykiem $w$ górnym marginesie. Inskrypcja: k. 4v: „F[rat]ris Ludovici Romani philosophiae lectoris“.

Składki: 18 seksternjonów, 18 bez $2 \mathrm{k}$. Kustosze literowe: A-S.

Filigrany: inicjały MWH, k. 3. Tarcza herbowa z korona, k. 215.

Oprawa płsk. cielęcy, tektura sklejana ze starej makulatury (w brakach okładki widać gotyckie pismo polskie). Brzeg górny nakrapıany na czarno.

Proweniencja: 1. O. Ludwik Roman.

2. Biblioteka OO. Kapucynów w Rozwadowie. Pieczątkıa okrągła, k. 1, wyklejka tylna. Sygn.: 322 .

R 40. Eac. 1764-1767. $21 \times 16.5 \mathrm{~cm}$. K. 235. Opr. ptsk. wsp.

1. k. 2-99v. ,Philosophia rationalis seu logica iuxta mentem Mariani Doctoris Joannis Duns Scoti, perducentis subtilitate sua alumnos suos in Scotiam. Exposita per Adm. Rndum Patrem Vitum Litomislien- 
sem pro tune lectorem philosophiae. Tradita anno.. 1764 die 19 septembris Roziampoli“".

Inc.: k. 2: „In ipso philosophiae aditu, quam $\mathrm{X}$ labores et fructus omnes dedicamus. Amen", k. 97.

2. k. 100-252. „Explanatio naturae hoc est philosophiae Aristotelicae pars secunda videlicet physica universalis, iuxta verum sensum ac mentem Subtilis Marianique Doctoris Venerabilis Joannis Duns Scoti explanata ac elucidata anno Domini 1765 die 4 novembris in Conventu nostro Roziampoliensi ad S. Rosam et Rosaliam".

Inc.: k. 100v: "Sub auspiciis Sapientiae increatae Patronorumque $\mathrm{X}$ omnmo deletum vollo. Haec igitur cedant", k. 247.

Szkoła: Studium domesticum kapucynów w Rozjampolu. Lektor: o. Wit Syrowy, Czech.

Paginacja oryginalna: nlb. 4, 153, nlb. 4; nlb. 2, 287, nlb. 12. Spis treści: $97 \mathrm{v}-99 \mathrm{v}, 247 \mathrm{v}-252 \mathrm{v}$. Na marginesach numery paragrafów. Rysunk1: k. 10v: „Propositiones“; k. 16: figury sylogizmów; k. 71v: „arbor porphyriana“. Inskrypcje: k. 234v: „Roziampoli ad S.S. Rosam et Rosaliam a. 1767 die 23 ianuarii“; k. 247: „Quae sunt finita... 1767 die. In Conventu nostro Roziampolıensi ad SS. Rosam et Rosaliam per me indignum Capucinum Fr. Vitum pro tune lectorem". W formie k. 253 załączony na końcu rękopisu dodatek pt. „Conclusiones ex logica pro examine die 8bris anno 1783 expositae in Conventu PP. Capucinorum Rozvadoviae".

Składki: 22. Ternion 22. Kwaterniony 2, 9. Septentrion 17. Pozostake seksterniony.

Filıgrany: dwa lwy stojące $\mathrm{z}$ tarczą herbowa, w polu trzy krzyże na ukos, k. 1. Nazwiskc: J Honig, k. 248. Nap1s: Zoon, k. 242.

Oprawa w grubą tekturę. Grzbiet 1 rogi obcıągnıęte sk. bydlęcą barwıoną na brązowo. Brzegı nakrapiane na niebiesko.

Proweniencja: 1. O. Wit Syrowy.

2. Biblioteka OO. Kapucynów w Rozwadowie. Pieczątka akrągła na wyklejkach. Sygn.: 332.

R 41. Eac. 1828. $24 \times 19 \mathrm{~cm}$. K. 172. Opr. brosz. wsp.

„Doctrina religionis theologico philosophica conscripta per Fratrem Josephum a Cupertino Tarnopoli anno 1828". Późniejszy napis tą samą ręką: "Bibliothecae donavit Rozvadoviensi PP. Capucinorum a. 1836".

Inc.: k. 2: "Universum hoc est opus sapientissimi Creatoris $\mathrm{X}$ quae revelabitur in nobis. Rom. 8“, k. 173 (wyklejka).

Szkola: "Collegıum cum publico studio philosophiae, gymnasio et convictu" jezultów w Tarnopolu. Prof. logiki i etyk1. o. Wincenty Buczyński ${ }^{120}$. Skryptor: br. Józef Krzysikiewicz, kapucyn.

Kodeks złożony $\mathrm{z}$ papieru czerpanego białego 1 siwego. Papier czerpany biały: k. 30-37. Reklamanty. $\mathrm{Na}$ marginesach liczne numery paragrafów.

120 Ur. 17 IIr 1689, do zak, wstąpil 1805, 2m. 29 IXI 1853. - Ks. J. B r o w n, jw. s. 139-140; Enc. Chelm. ViVI 202. Enc. Now. III 5; Enc. Orgelbr. IV 542; Pol. Stown. biogr III 90 (R. Miemeki); Ba cker-Som mervogiel II 329-330. 
Rzadkıe glosy. Inskrypcje: k. 46: „Secundum semestre"; k. 89: „Finis I anni $1827^{\prime \prime}$

Składki: 42 biniony. Kustosze literowe: A, B, C itd.

Filigrany: inicjały $\mathrm{P}$ W Z, k. 2.

Oprawa broszurowa w miękką tekturę białą. Szycie na 3 sznurki.

Prowenliencja: 1. O. Józef Krzysikiewicz, kapucyn. tylna.

2. Biblioteka OO. Kapucynów w Rozwadowie. Pieczątka okrągła, k. 1, wylklejka

\section{PRAWO SWIECKIE}

R 42. Eac. XIX w. $23 \times 18 \mathrm{~cm} . K$. 130. Opr. brosz. wsp.

„Elementa iuris. Liber III. Tit[ulus] $X^{\prime}$.

Inc.: k. 1: „De assignat. Iibert., k. 337, vero non extantibus liberis $X$ sed novus contractus ineatur, d. $\S$ ult. Inst. eod.", k. 130v.

Kodeks składa sıę $\mathrm{z}$ dwóch części: $\mathrm{z}$ właścıwego rękopisu oraz z kilkudziesıęciu kart (s. 337-468) druku Elementa ıuris, o wymiarach $17 \times 10.5 \mathrm{~cm}$., wlepionych między karty manuskryptu. Rękopıs zawiera komentarze 1 glosy - treści prawniczej.

Składkı: 9. Binion 9. Septentriony 1, 3, 5, 7, 8. Okternilony 2, 4, 6.

Filigrany: tarcza herbowa $\mathrm{z}$ koroną, poniżej inicjały $\mathrm{H} \mathrm{S,} \mathrm{k.} \mathrm{13,} 14$. Litera F, k. 19.

Oprawa $w$ tekturę obciągniętą papierem czerpanym, siwym.

Proweniencja: Biblioteka OO. Kapucynów w Rozwadowie. Pieczątka okrạgła na wykiejkach.

RETORYKA I POETYKA

R 43. Eac., pol. 1721-1722. $19 \times 15 \mathrm{~cm}$. K. 263. Opr. sk. wsp.

1. k. 3-250v. „Oceanus rhetoricus Celsissimorum Illustrissimorum Lubimirsciorum Srzeniava faederatus diverso rhetoricorum praeceptorum sinu exundans selectioribus eruditionum, scientiarum, apophtegmatum, symbolorum, gemmis ditescens. Facili praxium et orationum in omni materia claritate perspicuus in offensam latini styli puritate illimis. Fortunatis orationum maiorum tum etiam officiosarum, quae apud Polonos vulgo complementa vocantur, sermonum comitialium, funebrium, modorumque concionandi, nec non ipsarum concionum insulis famosus. Calamos, paginas, aures et animos rhetoricae iuventutis Lubomirsciani Ressoviensis Scholarum Piarum Collegii influens. Anno 1721 in 1722 desinente die 15 7bris diffusu's".

Inc: k. 4: „Proloquium ad rhetoricae studiosos. Parciose aliis scatebram tenuique reflexus $X$ proles aestimabo. Interim sit...", k. $250 \mathrm{v}$.

2. k. 253-261. „Orator perfectus e cathedra crucis salutem humani generis perorans Christus patiens ex oratoris suggestu rhetoricae Ressoviensis Scholarum Piarum declamatus. Perillustri ac Reverendissimo Domino Domino Paulo Antonio Cybulski canonico Opatoviensi, praeposito et officiali Pilsnensi, curato in Łęki, philosophiae doctori. In anno D. Pauli tutelaris sui recursu dedicatus anno Dni 172229 junii“. 
Inc.: k. 254: „Panegyricas tibi emerito acclamationes pro $\mathrm{X}$ o prodigam nimis numinis essentiam", k. 261.

Szkoła: Kolegıum pijarów w Rzeszowie. Profesor retoryki: o. Klaudiusz Krasnodębski ${ }^{121}$. Skryptor: prawdopodobnie Michał Hański.

Pagınacja oryginaina: nlb. 6, 627. Karty nezapisane: 2, 22v, 23, 24, 43v, $179,180,207 \mathrm{v}, 229 \mathrm{v}, 251,252,262,263 \mathrm{r}$. Glosy marginalne: $\mathrm{k}$. $\lrcorner 11 \mathrm{v}, 118,129$, $132 \mathrm{v}, 164 \mathrm{v}, 172$, 244. Karty końcowe w górnej częścı naprawıane.

Składkı: 46. Binıony: $1,4,7,16,18,19,20,25,26,28,30,31,32$, $35,38,39,41,43,44$. Terniony 3, 8, 9, 17, 22, 23, 27, 34, 36, 40. Kwaterniony 2. $5,6,10,11,13-15,21,29,33,42,45$. Kwinterniony 12,37 .

Filigrany: dwie postacie $z$ napisem ponad nimi: Valiiub, k. 197. Napis: Almodepapier, k. 193. Korona z krzyżem, k. 251.

Oprawa w sk. clelęcą barwioną na brązowo. Na grzbiecie trzy pola, zamalowane farbą olejną popielatą, z napisem tytułowym. Szycie na 4 sznurki. Kapıtałka ręcznie szyta. Brzegi nakrapiane na niebiesko.

Proweniencja: 1. „Applico hunc rhetorices librum PP. Capuoinis Bibliothecae Rosvadoviensi die 15 10bris a. Dni 1753. X. Michael Hański parochus Rozvadov[iensis]". Napis na oidwrocie k. tytułowej.

2. Biblioteka OO. Kapucynów w Rozwadowie. Pieczątka okrągła na wyklejkach. Sygn.: $469 ; 363$.

\section{MEDYCYNA}

R 44. Niem. $1788.22 \times 17.5 \mathrm{~cm}$. K. 88. Opr. ptsk. wsp.

„Ärtztes Buch von Lazaro Graff Henckel von Donnersmarck ${ }^{122}$ zusammen getragen. Siemianowitz den 1ten Januar 1788".

Inc.: k. 1: „M. Magnesia. M. Massa pillularum X Magnetropfen gegen anfallende Fieber. $143 \%, k$. 86v.

Rękopıs zawiera recepty lekarskie. Paginacja orygınalna: 100, nlb. 16. Karty niezapisane: $72 \mathrm{v}-80 \mathrm{v}$. Spis treśc1: k. 81-36v. Na wyklejce frontowe1 I na margınesach podpisy właścıciela.

Składki: 21 binuonów.

Filigrany: tarcza herbowa prawdopodobnie z herbem biskupım, widoczny fragment sztandaru, k. 73-80.

Oprawa w płsk. cielęcy. Papier czerpany klajstrowy. Na skórze ślady thoczenıa linearnego na ciemno. Szycie na 3 sznurki.

Proweniencja: 1. Lazarus Graff Henckel von Donnersmarck.

2. „Dieses Ärzeney Vorschriftbuch habe meinem damaligen Canzelisten Gotfried Hoffmehr geschenkt. Siemianowitz den 11 septembris 1792. Lazarus Graff Henckel von Domnersmarck". Naplis na wyklejce frontowej.

3. Biblioteka OO. Kapucynów w Roøwadowie. Pieczątka okrągła na wyklejkach.

R 45. Pol. 1877. $21 \times 17 \mathrm{~cm}$. K. 45. Opr. zeszytowa.

"Hygiasticon seu vera ratio valetudinis bonae et vitae una cum sen-

121 Prof. retorykı I fil., wicerektor domu w warszawıe, rektor koieglum w waręzu, zm. $23 \mathrm{~V} 1737$ w Dąbrowicy w $48 \mathrm{r}$. zycia, w zakonie przezyl 23 lata. - Liber suffragiorum Domus Podolinensis. Nomina defunctorum. Arch. Schol. Piarum Cracov. Coll. Crac. 12 s, 182; Enc. Chetm. XXIII/XXIV 24; Estr. (XX 237-238) podaje date urodz. pod. r. 1684, sm1erci $22 \mathrm{~V}$; Jo che r nr 5403.

122 Por. Gothasches genealogısches Taschenbuch der gräflichen Fiäuser 1896. Goiha s. 452-458. 
suum iudici et memoriae integritate ad extremam senectutem conservandae: auctore Leonardo Lessio Societatis Jesu teologo. Subiungitur tractatus Ludovici Cornari Veneti, eodem pertinens, ex italico in latinum sermonem ab ipso Lessio translatus - edilio secunda. Antverpiae ex Officina Plantiniana apud Viduam et filiis Jo. Mareti. MDCXIV".

Autorem rękopisu jest 0 . Mikołaj Czeczott ${ }^{123}$, kapucyn.

Proweniencja: 1. O. Mikołaj Czeczott.

2. Biblioteka OO. Kapucynów w Rozwadowwie. Pieczątka ołkrągła na okładkach.

\section{REKOPISY BIBLTOTEKI KLASZTORU W SĘDZISZOWIE}

\section{TEOLOGIA DOGMATYCZNA}

S 1. Eac. 1828. $23.5 \times 18.5 \mathrm{~cm}$. K. 194. Bez opr.

Theologia speculativa.

Inc.: k. 1: „ad Deum referuntur. Psal. 114, 6. Qui fecit X coronam imponit tunc erit metus", k. 194v.

Blok rękopisu składa się z papieru czerpanego, siwego. Karty niezapisane: 161, 162. Glosy marginalne. Poprawkı ołówkiem. Napis na k. 159: „Đie 18 octobris anni $1823^{\prime \prime}$.

Składki: 49. binıonów.

Filigrany: Nazwa: Rannersdorf, k. 2.

Proweniencja: Biblioteka OO. Kapucynów w Sędziszowie.

S 2. Łac. $1858-1866.23 .5 \times 15 \mathrm{~cm}$. S. 828, nlb. 4. Opr. ptsk. wsp. "Praelectiones de Deo uno et trino". (Tytuł drukowany).

Inc.: s. 3: ,Theologia, nominis significatione latiosi in usum $\mathrm{X}$ si non es praedestinatus, fac ut praedestineris", s. 825 .

Szkoła: Collegium Romanum jezuıtów w Rzymie. Prof.: o. Jan Franzelin ${ }^{124}$.

Skrypt szkolny wykonany litografią na zwykłym białym papierze. Zakładka w kolorach brązowo-bıało-żółto-nıebieskim. Errata na s. 826-828. Na końcu tekstu uwaga: „In Coll. Romano annis 1858, 1862, 1866“. Obok ołówkıem dopisano: ,17/10 $1894 \mathrm{fr}$ Victor [Klımek]".

Składki: 104 biniony.

Oprawa w plsk. francuski, cielęcy. Sk. czerwona, rożki kryte pergaminem. Papier marmurkowy fabryczny. Na grzbiecie 6 linii złoconych, jak też tytuł w górnej części, a w polach stemple o rysunku secesyjnym. Szycie na 3 sznur$\mathrm{ki}$, przeciągane przez tekturę. Kapitałka przyklejana. Wyklejka -papier zwykly biały. Brzegi czerwone.

Proweniencia: 1. „Bibliothecae PP. Capucinor[um] Convent[us] Cracovien[sis] applicavit fr Leo [Doliński] a Cracovia". Napis na s. tytułowej.

2. Biblioteka OO. Kapucynów $w$ Sędziszowie. Pieczątka podłuzina na s. tytułowej, 828.

123. Ur. 19 VII 1821 (1819?), do zak, wstąpił 1859, zm. 27 J.I $1907 \mathrm{w}$ Rozwadow1e. W r. 1872 przybył z diecezjl łucko-zytomıersikiej a nalezał do prowincji ruskıej kapucynöw. - Deserıptio Provinciae Galiciae k. 5. Rkps A,PK; Mortuologium, Jw.

224 Biografię I bibliografię zob. W Enc. Chetm. XI/XIX 388. 
S 3. Eac. $1868-1869.23 \times 15 \mathrm{~cm}$. S. 845, nlb. 3. Opr. ptsk. wsp.

"Tractatio de Deo Creatore". (Tytuł drukrowany).

Inc.: s. 3: „Propositum nobis est in hac brevi synopsi $\mathrm{X}$ Dei est poena peccato originali debita", s. 842 .

Szkoła: Collegium Romanum jezuitów w Rzymie. Prof.: o. Jan Franzelin.

Skrypt szkolny wykonany litografią na zwykłym bıałym papierze. Indeks na snlb. 3. Errata na s. 843-845. Zakładka zielona. Posiada ,Imprimatur Frater Marianus Spada O.P.S.P.A. Magister Anno 1868-1869".

Składki: 106 binionów.

Oprawa jak pod nr S 2.

Proweniencja: 1. O. Leon Doliński.

2. „Ad Bibjiothecam P. Capucinorum Sendziszoviensium“. Napis na k. tytulowej. Pieczątka podłużna na $k$. tytułowej $i$ odwrocie ostatniej strony. Sygn.: F. 80-152.

S 4. Eac. 1869-1870. $23 \times 15 \mathrm{~cm}$. S. 808. Opr. płsk. wsp.

„De gratia divina". (Tytuł drukowany).

Inc.: s. 3: „Aggredimur tractationem de gratia longam $\mathrm{X}$ quae citra condigna nobis praedestinatur", s. 800.

Szkoła: Collegium Romanum jezuitów w Rzym1e. Prof.: o. Jan Franzelin.

Skrypt szkolny wykonany litografia na zwykłym bıałym papierze. Indeks na s. 804-806. Zakladka zielona. Posiada: „Imprimatur. Fr. Marianus Spada O.P.S.P.A. Magister“. Na końcu tekstu uwaga: „In Collegio Romano anno $1869-1870^{\prime \prime}$.

Składki: 101 binıonów.

Oprawa jak pod nr S 2. 83-155

Proweniencja: jak pod nr S 2. Pieczątka podłużna na s. tytułowej i 800. Sygn.:

S 5. Łac. $1870-1871.23 \times 15 \mathrm{~cm}$. S. 894, nlb. 2. Opr. ptsk. wsp.

„De poenitentia. Tractatus scholasticus in S. Thomae 3 p. a q. 84 deinceps". (Tytuł drukowany).

Inc.: s. 3: „Opus est ut potissima doctrinae capita X si huiusmodi homines impune abire patiantur", s. 894.

Szkoła: Collegium Romanum jezuitów w Rzymie. Prof.: o. Jan Franzelın.

Skrypt szkolny wykonany litografia na zwykłym białym papierze. Indeks na 2 ostatnich snlb. Zakładka zielona. $\mathrm{Na}$ końcu tekstu napis: „In Collegio Romano anno 1870-1871“.

Składki: 112 binıonów.

Oprawa jak pod nr S 2.

Proweniencja: jak pod nr S 4. Pieczątka podłużna na s. tylułowej i 894. Sygn.: F. $81-153$.

S 6. Łac. $1871-1872.23 \times 15 \mathrm{~cm}$. S. 826, nlb. 2. Opr. płsk. wsp.

„Tractatus de ecclesia Christi. Sectio Ta. De ecclesiae caplite seu de Romano Pontifice". (Tytuł drukowany).

Inc.: s. 3: „Quandoquidem Christus Dominus ecclesiam suam X a Papa, lege praeterea Zaccaria antifebronio part. I diss. 2 c. 6", s. 826. 
Szkoła: Collegium Romanum jezuitów w Rzymie. Prof.: o. Jan Franzelın.

Skrypt szkolny wykonany Iitografią na zwykłym białym papierze. Errata i indeks na ostatnich dwóch nlb. stronach. Zakładka zielona. $\mathrm{Na}$ końcu tekstu napis: „In Collegıo Romano anno 1871-1872. Imprimatur. F. Marıanus Spada. O.P.S.P.A.M"

Składki: 104. Biniony $z$ wyjątkiem ostatnıej liczącej $2 \mathrm{k}$.

Oprawa jak pod nr S 2 .

Proweniencja: jak poid nr S 2. Pieczątka podłużna na s. tyitułowej i ostatniej. Sygn.: F. 82-154

S 7. Eac. 1871. $26.5 \times 20.5 \mathrm{~cm}$. K. 225. Opr. płsk. wsp.

„Praelectiones ex theologia dogmatica speciali in c[aesareo] r[egio] Franciscea. Universitate Leopoliensi habitae per Adm. Reverendum ac Clarissimum Dominum doctorem Sylvestrum Sembratowicz. In eadem Universitate professorem ordin[arium] publ[icum] theologiae dogmaticae fundamentalis et specialis, emeritum studiorum praefectum in Seminario generali, secretarium Excellentissimi Archipraesulis etc. Leopoli 1871.".

Szkola: Uniwersytet Lwowski. Prof.: ks. Sylwester Sembratowicz ${ }^{125}$. Skryptor: Aleksander Iwasiówka.

Oryginalna pagınacja: nlb. 8, XLVIII, 390. Liczne podkreślenıa w tekścıe. Inskrypcje: k. 224: „Leopoli. die 31 decembris 1870. Scrıpsı: Aleksander Iwasiówka auditor II anni sc. theol." $\mathrm{Na}$ karcie tytułowej dedykcja dla br. Edwarda Zelka, kap. kleryka, przez K. Prajera w Krakowie dnia 13. X. 1898.

Oprawa w tekturę szarą. Okładki obciągnięte papierem chagrain czarnym. Grzbiet w płpł. kaliko czarne. Tytuł na grzbiecie tłoczony złotem. Na grzbiecie linıe na ciemno.

Proweniencja: 1. Aleksander Iwasiówkla. Lwów.

2. K. Prajer. Kraków.

3. O. Edward Zelek, kapucyn.

4. Biblioteka OO. Kapucynów w Sędziszowie.

\section{TEOLOGIA MORALNA}

S 8. Łac. 1654. $10 \times 15 \mathrm{~cm} . K .277$. Opr. sk. wsp.

1. k. 1-109. "Quaestiones de sacramentis in genere. Ad 60imam quaestionem 3tiae partis $\mathrm{S}$. Thomae Doctoris nostri Angelici".

Inc.: k. 1: „Sacramentum 1mo significat rem quandam sacratam $\mathrm{X}$ 60 sima ad 80simam 6tam explicata inclusive sufficiant", k. 109v.

2. k. $110-217 \mathrm{v}$. „De adorando et divissimo sacramentorum sacramento eucharistiae. De sacrosancto sacrificio Missae quaestiones ard 3tiam partem S. Thomae a quaestione 73 ad 83 inclusive. Anno Dni 1654".

Inc.: k. 111: „Eucharisitia graecis: idem ac latinis honam $\mathrm{X}$ per physicam immutationem physicarum specierum eucharisticarum", k. $217 \mathrm{v}$.

125 Ur. 1836, arcybp metrop. lwowskı ob, unıckiego, kard. 1895, dzıałacz społeczny, zm. 1898 we Lwowie. - Enc. Chetm. XXXV/XXXVI 168; Enc. Now. XXV 7-3; Enc. Gutenberga XV 311. 
3. k. 218-263v. "Quaestiones de sacrificio novae legis".

Inc.: k. 218: „Dico ita et primo quidem est actio realis $\mathrm{X}$ semper Deo est suavissimus cibus sanctis acceptissimus", k. $263 \mathrm{v}$.

4. k. 264-277. "Quaestiones theologicae de sacramento ordinis seu de ordinibuis ecclesiasticis ex supplemento 3 tiae $\mathrm{p}$. S. Thomae ad qu. 34 et 35 tam, 36, 37, 38, 39 et $40 \mathrm{mam}$. Anno $1654^{\prime \prime}$.

Inc.: k. 264: „Ordo per antonomasiam dicitur status clericorum X ut potest ei dimissorias concedere. Et haec...", k. 277.

Kodeks bez karty tytulowej. Reklamanty. Paginacja oryginalna doprowadzona tylko do s. 17. Karty niezapisane: $110 \mathrm{v}, 175 \mathrm{v}, 176 \mathrm{r}, 277 \mathrm{v}$. Rzadkıe glosy marginalne. Tytuły 1 podtytuły wykonane ręcznie $w$ formie liter drukowanych. Na marginesach podane dokładne daty przerabianych traktatów. Na k. 228v napis: ,z Malechowa plebaniej X. Tera. .."Blok rękopisu wykazuje. ślady dawnego zawilgocenia.

Składki: 26. Binion 20 bez $2 \mathrm{k}$. wydartych. Terniony 1, 2. Kwinterniony $8,11,13,15,17,19,21,23,25$. Seksterniony $4,5,6,9,10$ bez 5 k. wydlartych. Septentriony $7,12,14,16,18,22,24.26$ ma tylko $3 \mathrm{k}$. Okternion 3.

Filigrany: mała tarcza herbowa z krzyżykiem w górze, k. 3, 4. Podwójny krzyż w polu herbowym, k. 265, 274.

Oprawa $\mathrm{w}$ tekture szarą, szmacianą. Grzbiet wzmocniony paskamı płótna. żaglowego. Okladki obciągnıęte sk. cielęca ściemnioną na brązowo. $\mathrm{Na}$ froncie tłoczona bokami ramka rolką o motywach późno renesansowych. Wewnątrz ramki w linearnym układzie, w narożnikach tłoki filigranów z powtórzeniem tegoż w pośrodku. Na tylnej okładce tenże sam motyw rolki powtórzony jako ujęcie w ramce linearnej, w pośrodku której zwierciadło zapełnione tym samym motywem dekoracyjnym. Na grzbiecie tytuł tłoczony ręcznie. Szycie na dwa więzy. Sznurki zaklejane od spodu. Spod wyklejki przebija makulatura polska z czcionką szwabachą i rzymską. Oprawa silnie zniszczona, szczególnıe w grzbiecıe.

Proweniencja: „Ex Bibliotheca P.P. Capuninorum Conventus Sędziszov[iensis]“. Napis na k. 1.

S 9. Łac. $1685-1686.19 \times 15.5 \mathrm{~cm}$. K. 191. Opr. ptperg. wsp.

1. k. 1-83. „Tractatus de praeceptis decalogi primae tabulae disputationibus et quaestionibus illustratus. Anno Dni $1685^{\prime \prime}$.

Inc.: k. 2: „Antequam agemus de adoratione cultusque Dei $\mathrm{X}$ praeceptis primae tabulae sufficiant hoc anno", k. $81 \mathrm{v}$.

2. k. 84-191. "Tractatus de praeceptis decalogi secundae tabulae disputationibus et quaestionibus illustratus. 1686".

Inc.: k. 85: „Praesenti disputatione agam de obligatione $\mathrm{X}$ consecro et emendanda ecclesiae iudicio submitto", k. 188v.

Tytuł rękopısu wykonany częściowo majuskułą. Brak kart ochronnych. Reklamanty. Paginacja oryginalna: nlb. 2, 178, nlb. 6; 308, nlb. 6. Karty niezapisane: $1 \mathrm{v}, 83 \mathrm{v}, 84 \mathrm{v}$. Karty wyrwane: 9 k. między k. 24 a 25, pozostały tylko dolne strzępy papıeru. „Index rerum“: k. 82-83, 189-190 w dwóch kolumnach. Glosy marginalne bardzo nieliczne. Na tylnej wyklejce napis: „Phi- 
losophus videns mulierem suspensam in arbore dixit haec verba utinam eiusmodi fructus portaverint semper arbores".

Składki: 25. Binıon 11. Ternıony 2, 5, 7, 9, 13, 15, 17, 19, 20, 21, 24. Kwaternion 12. Pozostałe kwinterniony ale 3 bez $3 \mathrm{k}$., 4 bez $1 \mathrm{k}$., 25 bez $4 \mathrm{k}$.

Filigrany: fragment filigranu, być może, orła dwugłowego, k. 184, 187.

Oprawa w tekturę szarą, półmiękką. Grzbiet pergamınowy. Okładka obciągnięta papierem czerpanym, barwionym na kolor jasno-brązowy i pokrytym tłoczeniami na cıemno o układzıe renesansowym. W zewnętrznej ramce rolki o motywıe roślinnym, w wewnętrznej natomiast arabeskı. Zwierciadło poclągnięte lınıami bıegnącymı po przekątnıach. Szycie na 3 wıęzy, wzmocnıone w grzblecie szarym płótnem zaglowym. Brzegı noszą ślady barwienıa dwukolorowego (zielonobrąowego). Wyklejkı tylko na okładce $z$ papieru czerpanego. Rzadki wypadek bogatego tłoczenıa na papıerze.

Proweniencja: 1. „Ex libris Joannis Remigrani“. Napis na wyklejce okładki frontowej. Dalsze dane nieczytelne.

2. „Ex Bibliotheca P. P. Capucinorum Conventus Sędziszoviensis". Napis na k. tytulowej i 2. Pieczątka podłuzna na $\mathrm{k}$. tytułowej.

S 10. Łac. 1712. $21 \times 16 \mathrm{~cm}$. K. 134. Opr. plsk. wsp.

"Tractatus theologicus de virtute et sacramento poenitentiae ad tertiam partem Divi Thomae a quaestione 84 ad quaestionem $90 \ldots$ In Collegio Leopoliensi anno Domini 1712 tertia februarii".

Inc.: k. 1v: „Prolusio. Inter funera et lugubres $\mathrm{X}$ tutelarium venerationem laborem praesentem consecramus", k. 134.

Szkoła: Kolegium jezuıtów we Lwowie. Profesorowie: o. Jerzy Dębski ${ }^{126}$ i o. Antoni Swirczyński ${ }^{127}$.

Karty niezapısane: $108 \mathrm{v}, 109 \mathrm{r} . \mathrm{Na}$ margınesach numery paragrafów. Rzadkie glosy marginalne. Napisy: k. 1: „Reverendi Patris Swirczyńskı professoris Seminarii in speculati[vis]"; k. 87: „Reverendi Patris Dębski".

Składki: 13. Kwinternıon 1 od k. $1-8$ i $21-25$, seksternıon 2 od k. $9-20$, obydwie składki zachodzą na siebıe przez podwinięcie. Biniony 7, 8. Ternıon 6 . Kwintermion 4. Pozostałe seksterniony.

Filigrany: fragment niezidentyfikowanego filigranu, k. 114, 117.

Oprawa półmıękka w płótno żaglowe sklejane zamıast tektury. Grzbiet obciagnnięty sk. bydlęcą barwioną na brązowo a okładki zwyklym papierem czerpanym. Szycie na 3 sznurkı. Brzegi barwione na zielono. Wyklejki brak. Ciekawy przykład sklejanı płótna żaglowego w użyciu zamiast tektury.

Proweniencja: „PP. Capucinonum Sędziszoviensium“. Napis na k. 1 .

S 11. Eac. $1738-1739.19 \times 15.5 \mathrm{~cm}$. K. 81. Bez opr.

1. k. 1-45. Tractatus de poenitentia.

126 Zm. 1733. - Ks. J. B row n, JW. s. 156-157; Enc. Chetm. IX/X 9; Enc. Orgelbr. VII 5859; J o cher nr 4498, 4908.

127 Ur. 11670 (bez daty dziennej), do zak. wstąpil 1688, zm. 10 vir 1728 w Krakowie. -Cat. I Domus Probationıs Cracoviensis a. 1690; ArSI, Pol. 20 f. $48 \mathrm{nr}$ 27; Necrol. Prov. Polonae S.J. II 1700-1754; ArSI, Pol. 69 f. 489; Ks. J. B rown, Jw. s. 392; Enc. Chetm. XXXVII/XXXVIII 266-267; Enc. Now. XXVII 295. Enc. Orgelbr. XXIV 377; J o c h e r nr 2496, 5664, 5665, 6097, 6098; Es t r. XXX 103-104. 
Inc.: $k .1$ : ,ex motivo suo partiendam ex motivo poenitentiae $\mathrm{X}$ quod annuus noster labor, in theologia panta expiret", k. 45 .

2. k. 46-81. „Tractatus theologiae moralis de confessione ac de censuris ecclesiasticis tam in communi quam in particulari, difficiliorum conscientiae casuum resolutione in compendium coniectus... In Collegio Sandomiriensi S. J. A. D. 1738 in $1739^{\prime \prime}$.

Inc.: k. 46v: "Cum theologia scholastica integrum anni praesentis tractatum $\mathrm{X}$ ad punctum unicum melumque operum erint proprium", k. 81 .

Szkoła: Kolegium jezuitów w Sandomierzu. Profesorowie: o. Józef Bystrzonowsk ${ }^{128}$ i o. Stanisław Kozłowski ${ }^{158}$.

Kodeks bez plerwszych 14 stron. Paginacja oryginalna: 15-103, druga część bez paginacji. Karty niezapisane: 45v, 71v, 72r, 81v. Na marginesach numery paragrafów. Glosy interlinearne. Każda strona znaczona $w$ górnym marginesie inicjałami: LJC Amen. Inskrypcja: k. 1v 1 81: „Deducta per moras ad finem die 17 iunii 1739 sub professore digno R. P. Stanislao Kozłowski".

Składki: 15. Biniony 7-15. Terniony 2 ,4, 6 bez $3 \mathrm{k}$. Kwinterniony 1, 3, 5 . Kustosze literowe. Brak pierwszej składki A.

Filigrany: tarcza herbowa z koroną i krzyżem równoramiennym $\mathrm{w}$ polu, k. 62, 65. Myśliwy, dmący $w$ róg, na koniu $w$ biegu, k. 55, 56.

Slady szycia na dwie tasıemki pergaminowe i resztki sk. na grzbiecie, z tłoczeniem linearnym na ciemno. Wyklejki, jak i oprawy, brak. Brzegi nakrapiane na niebiesko.

Proweniencja: Biblioteka OO. Kapucynów w Sędziszorwie.

S 12. Eac. 1778. $17 \times 11 \mathrm{~cm}$. K. 87. Bez opr.

"Compendium theologiae moralis succincte omnes in hac scientia tractabiles materias earumque definitiones ac divisiones complectens. Pro utilitate candidatorum theologiae Seraphici Ordinis nostri Capucinorum elaboratum ab A. V. P. Heraclio pro tunc lectore s. theologiae moralis a. D. 1778 die 239 bris".

Inc.: $\mathrm{k}$. 1v: "Cum theologia in se nimis ampla sit X iuxta constitutiones posset excepto tempore duorum...", k. $87 \mathrm{v}$.

Szkoła: Studium domestıcum kapucynów. Lektor: o. Herakliusz Grekka ${ }^{130}$.

Kodeks bez końca. Reklamanty. Karty niezapisane: 36v, 37. Pierwsza składka oderwana od bloku rękopısu. Tytuł w podwójnej szerokıej ramce $z$ floraturą.

Składk1: 11. 11 ma 2 k. Ternion 1 . Kwaterniony $2+1 \mathrm{k} ., 3,4,5$ bez $1 \mathrm{k}$, $7,8,10$. Seksterniony 6. 9 .

1:8 Ur. 18 III 1694, do zak. Wstąpil 1709, zm. mlęazy 1770 a 1772. - Cat. I Coll. Ostrogiensis S. J. a. 1770; ArSI, Pol. 42 f. 102; B a cke r-S o m m e rvoge 1 II 479; Enc. Chelm. V/VI 241; Estr. XIII 183 .

129 Ur. 6 VI 3700 , do zak. wstąpił 1717, zm. 1768. - Cat. I Coll. Sandomirıensıs S. J. a. 1743; ArSt, Pol. 27 f. 258 nr 16: Ks. St. $Z$ a t ę s k I, Jw. T. 3 s. 1206, 1208, 1222, 1397; t. 4 s. 1720.

130 Ur. 24 IV 1737, do zak. wstąpil 1761, zm. 15 VII 1789 we Włodzımıerzu Wołyńskım. CPP nr 284; Mortuologlum, Jw., O. Z. Gorl1 c k1, Jw. s. 26?. 
Filigrany: tarcza herbowa z koroną pięciopałkową, k. 3. Nazwısko: J Honıg, k. 4.

Z dawnej oprawy pozostało szycie na 4 sznurki.

Proweniencja: 1. O. Herakliusz Grekka.

2. „Hic libellus concessus est F. Aidano [Kubalski] Capucino". Naplis na k. tytułowej.

3. „Mordo autem ad usum Fr. Damasi [Ścisłowicz] clerici novitii Olescensi 9 8bris 1831". Napis na k. tytułowej. $55,87 \mathrm{v}$.

4. Bibliateka 00 . Kapucynów w Sędziszowrie. Pieczątka podłużna na $k \cdot 40 \mathrm{v}$,

S 13. Eac. II pot. XVIII w. $16 \times 10 \mathrm{~cm}$. K. 149. Opr. sk. wsp.

"Cursus theologiae moralis abbreviatus seu compendium".

Inc.: k. 4 ,Haud quisquam erit ab Adamo descendentium $X$ sed quia ab huius consanguineo in secundo", k. 149.

Kodeks bez końca. Paginacja oryginalna: nlb. 8, 278. Wklejki: 73a, 107a. Glosy interlinearne. Rysunek ,arbor consanguinitatis" na k. 143. Na pierwszych dwóch kartach ochronnych i k. $3 \mathrm{v}$ znajduje sie fragment kazania w jęz. polskim.

Składki: 19. Terniony na przemian $z$ kwinternionami. Ostatni kwinternion +1 tablica. Przy końcu $2 \mathrm{k}$. wycięte.

Filigrany: fragment niezidentyfikowanego filigranu $w$ górnym lewym rogu karty.

Oprawa w tekturkę szarą szmacianą, w całą sk. cielęcą barwioną na brązowo. $\mathrm{Na}$ grzbiecie koło więzów na okładkach linie proste wycıskane na ciemno. Okładki podniszczone. Szycie na 2 sznurki. Brzegi barwione na brązowo.

Proweniencja: 1. „Fr. Innocentius Odorowski, indignus clerieus Capuc[inus]". Napis na k. 2v z XIX w.

2. Biblioteka OO. Kapucynów w Sędziszowie. Pieczątka podłużna na k. 3.

S 14. Eac. II pot. XVIII w. $20.5 \times 16 \mathrm{~cm}$. K. 72. Opr. brosz. wsp. "Tractatus quartus theologize universalis seu theologia moralis".

Inc.: k. 1: „Cum et inter ipsos Gentiles Cicero $\mathrm{X}$ ut prohibita et a sponsis ut futura", k. $72 \mathrm{v}$.

Treść: rękopis zawiera traktat „de ultimo fine hominıs eiusque beatitudine ac de actibus humanis" oraz o dziesıęciu przykazaniach Bożych. Nie posiada zakończenia dziesiątego przykazanla. Reklamanty wystepuja rzadko. $\mathrm{Na}$ marginesie numery paragrafów. „Tabella recitandarum horarum canonicarum“, k. 48.

Składki: 9 kwaternionów.

Filigrany: fragment niezidentyfikowanego filigranu $z$ inicjałami $G R$ u dołu, k. 45, 46, 69 .

Oprawa w broszurę, obciągnięta grubym papierem czerpanym siwym, wzmocnionym wyklejka papieru czerpanego zwykłego. $\mathrm{Na}$ okładce frontowej połowa druku $i$ herbu $z$ koroną z labrami i częścią napisu Fine pod tarczą. Szycie na 2 paski skórzane.

Proweniencja: Biblioteka OO. Kapucynów w Sędzilszowie. Pieczątkia podłużna: k. 1, 7, 50. Sygn.: $\mathrm{D}-37$. 


\section{TEOLOGIA PASTORALNA}

S 15. Pol. 1875. $24.5 \times 19 \mathrm{~cm}$. K. 262. Opr. ptpt. wsp.

,Teologia pasterska napisana według wykładu Najprzewielebniejszego ks. Józefa Kazimierza Martusiewicza ${ }^{131}$, kanonika kapituły Tarnowrskiej, profesora teologii pasterskiej. Tarnów 1875“. (Druk).

Skrypt litografowany. Między k. 89 a 90 przełamany. Paginacja oryginalna: 309; 206, IV. Spis rzeczy: k. 260-262.

Oprawa w tekturę szarą. Grzbıet w płpł. kaliko czarne. Okładki obciągnięte czarnym papierem chagrain. Na grzbiecıe lınie z tytułem na ciemno.

Proweniencja: Biblioteka OO. Kapucynów w Sędziszowie.

S 16. Pol. 1896. $20 \times 16.5 \mathrm{~cm}$. K. 267. Opr. ptpt. wsp.

„Teologia pasterska. X. dr J. Łabudy ${ }^{132}$ prof. teologii. Przemyśl. Odbito w Seminarium. 1896".

Skrypt litografowany, kończy sıę na k. 258v, dalsze niezapisane.

Oprawa $w$ karton $z$ czarnym płótnem kaliko na grzbiecie.

Proweniencja: Biblicteka OO. Kapucynów w Sędziszowie.

\section{HOMILETYKA}

S 17. Pol., tac. 1638. $15.5 \times 10 \mathrm{~cm}$. K. 173. Opr. ptperg. wsp.

„Fragmenta et additiones variarum concionum de dominicis ac nonnullis solemnioribus festis et quibusdam Quadragesimae ferijs".

Inc.: k. 2: "Circa finem exordii hoc ponendum. A poniewasz taką ma miłość ten Pan X gdzie ty z Ojcem i Duchem Ś. etc. Amen“, k. 173v.

Dodatkı na k. 110-121. Kazanı śwıąteczne 1 dodatkı do nich na k. 122-173. Bez karty tytułowej. Reklamanty. Karty niezapısane: 1.v, 121, 172v. Karty sklejane: 21, 22, 51, 53, 61, 62, 63, 131, 132, 135, 139, 140, 153, 154, 155. Wklejk1: k. 14, 23, 28, 53, 156. Czerwone uchwyty na k. 110, 122. Glosy marginalne. Inicjały rubrykowane. Ślady lekkiego zawilgocenia.

Składkı trudne do obliczenia.

Filigrany: fragment fillgranu w górnym lewym rogu karty.

Oprawa w cıenką tekturkę. Grzbıet obłożony sk. baranıą białą. Okładka obciągnięta papierem czerpanym barwionym na czerwono. Okładka tylna silnie zgryzıona przez korniki. Szycie na 2 paski pergaminowe, zaklejane od wewnątrz. k. 2 .

Proweniencja: Biblioteła OO. Kapucynów w Sędziszowie. Pieczątka podłużna

S 18. Pol., łac. 1690. $19.5 \times 15.5 \mathrm{~cm}$. K. 282. Opr. sk. wsp.

„Kazania na różne Panny Przenaśw. uroczystości w kościele Chrystusowym przypadające przez x. Andrzeja Franc. Mathuszewicza, ple-

131 Enc. Chelm. XXV/XXVI 233-294; Es tr. Ser. IV, III 129-130; Ks. J. S. P e 1 c z ax. Zarys dzıejów kaznodzıejstwa w Polsce. Kraków 1917 s. 413.

${ }_{132}$ Ur. 1856, wyśtv. 1881, prof, teol. pastoralnej w Seminarium Duchownym w Przemyślu. 
bana Wislskiego. $Z$ różnych authorów zebrane i opisane. Roku Pańskiego 1690.

Inc.: k. 3: „Waleczny zwycięzca Alexander, podbiwszy pod moc swoję krain wiele X jedna tylko nadzieja Marya, której ja pożądając nezastaje ", k. 280v.

Reklamanty. Paginacja oryginalna: $2 \mathrm{k}$. ochr., 278, nlb. 4. Karty niezapisane: 281, 282. Tytuł wypısany w większej części majuskułą. Rzadkie glosy marginalne i poprawki $w$ tekście. $\mathrm{Na} \mathrm{k}$. ochr. pierwszej i 2 tytuł 1 „regestr kazań“. Po k. 281 wyrwane 3 k., po k. 282 wyrwanych kilkanaście kart. Przy niektórych kazaniach podano miejsce, rok i dzień wygłoszenıa tychże. Na wyklejce frontowej modlıtwa do Matki Bożej i wiersz ku Jej czcı w jęz. łac.

Składkı: 35. Binion 26. Ternıony $3,4,13,21,22$. Seksterniony $14+1$ k., 33, 34, 35 bez $1 \mathrm{k}$. Pozostałe kwaterniony.

Filigrany: fragment filigranu $z$ napisem: Gretz, k. 281.

Oprawa z końca XVII w. Do obclągnięcıa tektury użyto jasnej, cielęcej sk. $z$ pięknymı tłoczenımi na ślepo motywów renesansowych za pomocą dwóch rolek renesansowych $\mathrm{z}$ główkamı $\mathrm{w}$ medalionikach. W zwierciadle znajdują sıę późno gotyckie stemple. Oprawa w późniejszych czasach otrzymała grzbıet ze sk. cıelęcej zabarwıonej na brązowo. Na nıej również odcıśnięto rolką renesansową główkı męskie pseudorzymskıe z podpisami. Napisy ponad medalionikami oprawy: Cicer[o], Ovldiv[s], Ivlivs, Virgili[vs]; napisy pod alegorıamı cnót: Carıt[as], Spes, Fides, Ivstıc[ia]; napisy ponad medalınikami na grzbiecie: Ovidiv[s], Ivlıvs, Virgili[vs]. Grzbiet bez tłoczeń. Szycie na 3 sznurki. Kapitałka ręcznie wyszywana. Później dodano tasiemki do wiązania. $\mathrm{Z}$ nıch zachowała się tylko jedna.

Proweniencja: 1. Ks. Andrzej Franciszek Mathuszewicz.

2. „Liber Francisci Danecki“. Napis na brzegu dolnym i bacznym.

3. „Ex libris Ignatii Łodzia de Eagiewniki Brodzkii“. Napis na tylnej wyklejce.

4. Bibdioteka OO. Kapucynów w Sędziszowie.

S 19. Pol., tac. 1780. $20 \times 12 \mathrm{~cm}$. K. 185. Opr. sk. wsp.

„Breviarium missionariorum scriptum Crosnae 1780. In hanc seriem redactum a $\mathrm{P}$. Amando missionario apostolico".

Inc.: k. 2: „W poselstwie do was tu przychodze $\mathrm{X}$ finivi hoc opusculum 24 martii.", k. $185 \mathrm{v}$.

Pismem XX w. pierwsze słowo przekreślono 1 ponad nim wpisano ołówkiem koplowym „Conciones". Dawniejsza oryginalna paginacja znaczona kopiowym olówkiem od s. 7-11 w górnej części karty, natomiast od k. 12-372 w dolnej. Obecna folıacja wykonana w całości na kartach w dolnym marginesıe. K. 181 luźna a $185 \mathrm{w}$ dolnym prawym rogu oderwana. Wyklejka frontowa, jak a konıec rękopisu, wyrwana. Spis kazań na k. 1. Pod każdym kazaniem podana data ukończenia go. Karty w górnym marginesie znaczone krzyzykiem. Rẹkopis wykonany duktem lukowym, atramentem brązowym z licznymi podkreślenıamı.

Składki: 24. Terniony 1 bez 1 k., 3, 5, 7, 9, 11, 13, 15, 17, 19, 21, 23. Kwaternion 6. Pozostałe kwinterniony ale 24 bez $3 \mathrm{k}$. 
Filigrany: fragment filigranu w lewej górnej części karty.

Oprawa w deski obciągnięte w sk. clelęcą barwioną na brązowo. Na grzblecie koło więzów linıe tłoczone na ciemno łaczące sie z podwójną ramką na okładce, tłoczoną na ciemno. W narożnikach ramki i na wysokośc1 więzów od strony grzbletu tłoczone rozetki. Oprawa zaatakowana przez korniki. Szycie na 4 wıęzy, zaklejane od wewnątrz. Rzemyki do zapınanıa zakończone metalową klamerką zapınaną na gwoździe okładki. Kapıtałka szyta. Brzegi czerwone.

Prowenliencja: 1. O. Amand Kuczera, Czech, kapucyn.

2. Biblioteka $O O$. Kapucynów $w$ Sędziszowie.

S 20. Eac. II pot. XVIII w. $19 \times 11.5 \mathrm{~cm}$. K. 157. Opr. płsk. wsp. Conciones.

Inc.: k. 1: „Sicut Moyses exaltavit, serpentem in deserto X item animalia licentiam nacta sunt ait S. Hieron[ymus]", k. 157v.

W rękopisie wyrwano karty ochronne wraz z tytułową i ostatnie składkı. Zawiera kazania swıąteczne. Na k. 8 zaznaczona miejscowość wygłoszenıa kazania: „Magieroviae“. Napısany przez jednego z kapucynów. Paginacja oryginalna: 314. Liczne podkreślenia. Karty w górnym margınesıe znaczone krzyżykiem.

Składkl: 18. Kwaterniony i kwinterniony przeplatają się na przemian od 1 do 10. Kwaterniony 11, 12, 14, 15-17, 18+1 k. Kwinternion 13.

Filigrany: Matka Boska z Dzieciątkiem, k. 17, 36. Fragment filigranu w górnej części karty.

Oprawa w tekturę szarą. Grzbiet i rogi w sk. cielęcą barwioną na ciemno. Na grzbiecie linie podwójne tłoczone na ciemno. Okładki obciągnięte papierem czerpanym klajstrowym, barwionym na brazowo. Oprawa zaatakowana przez kornikı. Szycie na 3 więzy. Brzegı nakrapiane na czerwono.

Prowemiencja: Biblioteka OO. Kapucynów w Sẹdziszowie.

S 21. Pol. 1775-1828. $18.5 \times 16 \mathrm{~cm}$. K. 157. Opr. sk. wsp.

„Per diversos veros eremitas S. P. N. Francisci np. Capucinos concionatores celeberrimos huius Conventus compositus. Conciones variae super eo".

Inc.: k. 1: „przystępuje do przyjęcia tego chleba niebieskiego $\mathrm{X}$ o jak się oni na tym mylą niech każdy asądzi“, k. 157.

Tytuł znajduje się na wyklejce okładki. Rękopis wykonany kilkoma rękami. Karty wyrwane z początku i końca rękopisu. Ulożony przez kleryka kapucyńskiego Leonarda Katanę ${ }^{133}$. Paginacja oryginalna: 314 . K. 132 luźna. Karty niezapisane: $51 \mathrm{r}, 121 \mathrm{v}, 122 \mathrm{v}$. Liczne podkreślenia 1 przekreślenıa. Pod tytułem prawıe nieczytelny podpis: „Fr. cl[ericus] nov[itius] Leonardus Katana. $1828^{\prime \prime}$. Jego biografia na k. $50 \mathrm{v}$. Na k. $157 \mathrm{v}$ podany wykaz kapucynów w Sędziszowle z r. 1828. Na wyklejce tylnej okładki notatka meteorologıczna z r. 1828 .

Składki: 22. 21 ma 2 k. Ternıny 2, 4, 5, 6, 8, 9, 11, 13, 20. Kwaterniony 14-18. Pozostałe kwinterniony lecz 10, 19 i 22 bez $1 \mathrm{k} ., 12$ bez $2 \mathrm{k}$. wyciętych.

183 Ur. 16 V 1804 w IMyślenicach, do zak. wstąpil 1827, zm. 9 VII 1879 w Olesku. - Teologii nie skończył, przeszedł na brata zakonnego. - Mortuologium, jw.; Kartoteka autora. 
Filigrany: Matka Boska z Dzieciątkiem w otoku promienj, k. 47, 153. Inicjały C N, k. 150. Zdobnik z inicjałami P F M, k. 83.

Oprawa w tekturę szmacıaną i w całą sk. cielęcą barwioną na brązowo. Ramka wyciśnıęta trzema liniami prostymi. Szycie na 3 sznurki. Brzegi nakrapiane.

Proweniencja: „Ex Archimetropolitana Bibliotheca PP. Capucinorum Sędziszoviensium. A. D. 1775-1828". Napis ręką L. Katany.

S 22. Pol, tac. I pot. XIX w. $16.5 \times 10.5 \mathrm{~cm}$. K. 116. Opr. ptpt. wsp. "Nauka katechizmowa".

Inc.: k. 1: „P. Co to jest katechizm? O. Jest nauka wykładająca początki wiary X i tak nieszczęśliwie żywot swój skończył", k. 116v.

Reklamanty. Blok rękopısu zawilgocony zdawna od strony brzegu, a ostatnio prawie w całośc1.

Składki: 15. Binion 15. Pozostałe kwaterniony.

Filigrany: fragment filigranu w lewej górnej części karty $i$ w lewej dolnej części wyklejki tylnej.

Oprawa póltwarda w szare płótno na grzbiecie, obciągnięta papierem czerpanym klajstrowym, z ornamentem o podkładzie czerwonym i zielonymi kółkami (prawdopodobnie drzeworytnıczymi). Szycie na 2 sznurki.

Proweniencja: 1. „Paululs Woycicki". Napis na odwrocie okładki frontowej.

2. Biblioteka $O O$. Kapucynów w Sędziszowie.

S 23. Pol., tac. XVIII-XIX w. $25.5 \times 19.5 \mathrm{~cm}$. K. 148. Bez opr.

Kazania niedzielne i świąteczne.

Inc.: k. 1: „Bracia moi. Chrystus dziś chwałe swoją okazuje X i dzieł w sercach i duszach naszych"6, k. $147 \mathrm{v}$.

Kazania różnych kapucynów z prowincji polskiej i galicyjskiej. Papier czerpany prążkowany 1 zwykły, biały i siwy. Karty niezapisane: $4 \mathrm{v}, 10,20 \mathrm{v}$, $24,28,36 \mathrm{v}, 50,54 \mathrm{v}, 79 \mathrm{v}, 83 \mathrm{v}, 87,99 \mathrm{v}, 103 \mathrm{v}, 127,128,140 \mathrm{v}, 142,149 \mathrm{v}, 157 \mathrm{v}$; $163 \mathrm{v}, 168 \mathrm{v}, 172 \mathrm{v}, 186,198$. Zapıski: k. 103: „Vidi in visitatione canonica 1841. Fr. Benjamin Cap. p[rovincialis]“; k. 163: „fr. Michael“; k. 192v: ,u św. Ducha w Lublinie r. 1848 fr. Michael".

Składki: $47.15,36$ po $1 \mathrm{k} .2,20,25,32,44$ po $2 \mathrm{k} .29$, po $3 \mathrm{k}$. Biniony $1,3-4,6,11,13,14,16-18,21,22,24,26,27,30,33,37-39,42 ; 43$. Terniony $5,12,19,23,28,31,34,40,41,46,47$. Kwaternion 45 .

Filigrany: nazwa: Sekowa, k. 2, 3. Tarcza herbowa z sześciopałkową korona, w tarczy kwıat, k. 1, 4. Napıs: Wadang, k. 6, 69, 70. Nazwa: Marzdorf, k. 42, 43. Matka Boska z Dzieciątkiem w koronach w owalu, k. 56, 57, 68, 71. Napıs Wadang, k. 58. Tarcza herbowa z koroną i Matka Boska z Dzieciątkiem w koronach, stojąca na półksiężycu, bez otoku, k. 94, 97, 98, 99. W otoku dwóch laurowych (?) gałązek skrzyżowanych ze sobą glowa męska, k. 100, 103 i napisy: Blefschniedt, k. 102, Konstantinow, k. 101. W tarczy herbowej trzy lilie, ponad tarczą korona plęciopałkowa, poniżej inicjały G F C, k. 105, 106. Matka Boska $\mathrm{z}$ Dzieciątkıem $\mathrm{w}$ koronach $\mathrm{w}$ otoku promieni, poniżej inicjały: $\mathrm{OH}+\mathrm{WA}, \mathrm{k} .105,106$. Nazwa: Modliborzyc, k. 182, 183 i stylizowana roślina lub drzewo, k. 180, 185.

Proweniencja: Biblioteka OO. Karpucynów w Sędzíszowie. 
S 24. Pol. XVIII-XIX w. $25 \times 21 \mathrm{~cm}$. K. 285. Bez opr.

Kazania świąteczne.

Inc.: k. 1: „Szczepan ś[więty] pełen łaski i mocy czynił wszelkie cuda X żebyśmy w nim życie odiebrali wieczne. Amen", k. 285.

Kazania różnych kapucynów z prowincji polskiej i galicyjskiej. Papier czerpany prążkowany i zwykly, biały i siwy. Karty niezapısane: 14, 22, 29v, $30,44 \mathrm{v}, 56 \mathrm{v}, 60 \mathrm{v}, 68 \mathrm{v}, 72 \mathrm{v}, 88,102 \mathrm{v}, 135,144,151 \mathrm{v}, 152,153,192 \mathrm{r} ., 200 \mathrm{v}$, $208 \mathrm{v}, 215 \mathrm{v}, 223,235 \mathrm{v}, 245,273 \mathrm{v}, 281,285 \mathrm{v}$. Inskrypcje: k. 13: „na Piasku u XX. Karmelitów w r. 1854. Fr. Michael Cap.“; k. 29: „Lublin, św. Duch. fr. Michael“; k. 44: „u św. Barbary we wrześniu 1852 r.“; k. 61: „u św. Barbary dla Tow. Dobroczynności r. P. 1852"; k. 64: „Cracoviae d. 7 martii 1852 a. Fr. Michael Capucınus“; k. 65: „U św. Barbary rok 1852 w św. Trójcę“; k. 72: ,,u Panien św. Andrzeja. Rok 1860"; k. 102: „In coemeterio cracovliensi] d. 8 nov. 1852 an.“; k. 123: „Cracoviae pro 17/II 1855“; k. 134v: „,na Smoleńsku w Krakowie d. 14 wrześnıa 1852. Ks. Michał"; k. 143v: „u XX. Reformatów w Krakowle d. 14 września 1856. Ks. Michal"; k. 181: „u PP. Franciszkanek w Krakowle d. 2 sierp. 1853 r. fr. Michael Cap.“; k. 188: „w Zakroczymiu“; k. 193v: „Frankowi Mady z Charzowic, w sobote ukradziono konia w noce“; k. 200: ,apud Spiritum Sanctum. Fr. Michael Cap. Lublinı 1849. d. 29 czer. 1851 w Bolechowicach u X. Cieszyńskiego“; k. 215: „Miane w kościele kroczewskım roku 1847 die 24 czerwca“; k. 239v: „Dixi Vlodimiruae 1790. fr. Damasus probando atramentum me subscripsi“; k. 263v: „fr. Michael anno 1853 apud moniales bernard[inas]".

Składki: 51. 9, 27, 49, 50 po $2 \mathrm{k}$. Binıony $7,10,11,12,13,14,20,26,29$, $30,33,37-42,45,48$, 51. Terniony $1,5,8,15,16,17,19,21,22,28,32$; $36,43,44$. Kwaterniony $2,3,4,6,18.23,24,25,31,34,35,46$. Kwinternion 47.

Filigrany: napis Hafermia S P, k. 38. Gros, k. 51. Inicjały I G Z, k. 56, 237. Orzel z berlem, k. 103, 106. Spleciony inicjal J A S, k. 104, 105. Inicjal C I F, k. 154, 157. Jednorożec w biegu, k. 155, 156. Nazwisko: D \& C Blauw, k. 168, 169. Tarcza herbowa $\mathrm{z}$ koroną pięciopałkową, $\mathrm{w}$ polu róg myślıwski na taśmıe, pod herbem nazwisko: D\& C Blauw, k. 167, 170. Napis: Wadang, k. 172, 238. Matka Boska $\mathrm{z}$ Dziecıątkıem w koronach $w$ otoku promıen, k. 171, 174. Napis: Bzıerzıe, k. 202. Tarcza herbowa z koroną pięciopalkową, w polu trzy lilie, k. 209. W ozdobnym owalu portret króla a poniżej napis: Fridrich Wilhelm d III, k. 220, 223. Inıcjały I W F, k. 221. R Pechemauseu, k. 222. Lilıa, k. 232, 235. Inıcjaly I V, k. 233, 234. Nazwisko. F Z Schut, k. 280. 281.

Proweniencja: Biblioteka OO.Kapucynów w Sedziszowie.

S 25. Pol. XVIII-XIX w. $25 \times 19.5 \mathrm{~cm}$. K. 173. Bez opr.

Kazania niedzielne.

Inc.: k. 1: „Być niewinnym a prześladowanym jest to zadatek $\mathrm{X}$ ciągu dni błogoslawionego życzę losu. Amen", k. 173.

Kazania różnych kapucynów z prowincji polskiej i galicyjskiej. Papier czerpany prążkowany i zwykły, biały i siwy. Karty niezapisane: $12 \mathrm{v}, 25 \mathrm{v}$, $26,30 \mathrm{v}, 36 \mathrm{v}, 42,50 \mathrm{v}, 53 \mathrm{v}, 54,60 \mathrm{v}, 66 \mathrm{v}, 69 \mathrm{v}, 70,78 \mathrm{v}, 84 \mathrm{v}, 33 \mathrm{v}, 98 \mathrm{v}, 104$; $105,119 \mathrm{v}, 123 \mathrm{v}, 139 \mathrm{v}, 143 \mathrm{v}, 147 \mathrm{v}, 153,157 \mathrm{v}, 169 \mathrm{v}, 173 \mathrm{v}$. Inskrypcje: k. 31 : „Varsaviae"; k. 37: „Łomża 1741"; k. 41v: „Vidi in visitatione canonica 1841. 
Fr. Benjamin. Cap. M[inister] P[rovincialis]“.

Składkı: 38. 17, 18 po $2 \mathrm{k}$. Biniony $1-5,7,10,12,15,19-21,25-28$, $31,32,34-38$. Terniony $6,8,9,13,14,16,22,24,29,30,33$. Kwaternion $23 \mathrm{bez} 1 \mathrm{k}$.

Filigrany: inicjały $\mathbf{F} \mathrm{T}, \mathrm{k}$. 4. Tarcza herbowa $\mathrm{z}$ koroną pieciopalkową, $\mathrm{w}$ polu na taśmie róg myśliwski, ponıżej herbu napis: Jezıorna, k. 2, 3; Buczacz, k. 5, 6, 7, 8. Matka Boska z Dziecıątkiem w otoku promieni, k. 45, 46. Inıcjały H A I, k. 43, 44. Nazwisko: I Z Schut, k. 49. 'Tarcza herbowa z korona pięciopałkową, w polu róg myśliwski na taśmıe, poniżej inicjały $\mathrm{V} A, \mathrm{~A} .47,50$. Sekova, k. 163, 164. Tarcza herbowa z koroną pięciopałkową, w polu motyw kwiatowy, k. 162, 165. Inıcjaly K D, k. 64. Zdobnik kwiatowy, k. 77, 78.

Proweniencja: Biblioteka OO. Kapucynów w Sẹdziszowie.

S 26. Pol., łac. XVIII-XIX w. $25 \times 20.5 \mathrm{~cm}$. K. 240. Bez opr.

Kazania świąteczne i okolicznościowe.

Inc.: k. 1: „Już đi od ojców św. ta ewangeliczna niewiasta X twojej macierzyńskiej doznał na sobie opieki. Amen", k. 239v.

Kazania różnych kapucynów z prowıncji polskiej l galicyjskiej. Papier czerpany prążkowany i zwykły, biały i siwy. Zapiskl: k. 6v: „1859“; k. 67: „fr. Michael 1852 in Zwierzyniec“; k. 88-95: „Mowa kaznodziejska na pogrzebie JW z Junoszów Podoskich Katarzyny v. Cauden Trzecieskiej, kasztelanowej Ziemi Dobrzyńskiej, miana w Rywałdzıe w kościele Ojców Kapucynów dnia 9 maja 1786 roku“. K. 95: „Dixıt ac perorat ARP. Casimirus [Zdarzil] $\mathrm{s}$ [anc] tae theologiae emeritus ac doctissimus vir ac professor". K. 101: ,R. 1797 w Lublinie“; ,1808 w Baworowie“; k. 104: „Anno Dnı 1788“" (o. Damazy Stehlik); k. 177-180v: „Mowa pogrzebowa przy zwłokach świętej pamıęc1 JW. Sylwerego Strzeleckıego sędzıego najwyższej instancji i referendarza stanu“; k. 191: „d. 29 wrześnıa 1855 r. u XX. Paulinów w Krakowie. fr. Michael Capuc."; k. 205-207: Kazanie w jęz. łac. z elementami niemieckiego gotyku, napisane przez jednego $z$ kapucynów czeskich w I pol. XVIII w.

Składki: 50. 2, 3, 5, 7, 27, 34-36, 39, 41, 42. Biniony 4, 6, 8, 12, 17, 18, $20,21,22,24,25,26,29,33,37,40,44,47,48,49$. Terniony 1, 3, 11, 14, 15, 16, 28, 30, 43, 45, 50. Kwaterniony 10, 32, 46. Kwinternion 10. Septentrion 31. Okternion 23.

Filigrany: napis: Wadang, k. 10. Matka Boska z Dzieciątkiem w otoku promieni, k. 13, 14. Nazwa: Wierlokow, k. 46. Tarcza herbowa z koroną, k. 47, 48. Matka Boska z Dzieciątkiem w koronach w otoku promienı, k. 79, 82. Inicjały W. K., ponizej nazwa: Wola, k. 39, 42. Stylizowane drzewo (świerk?), k. 38, 43. Zdobnik kwiatowy i inicjały I G, k. 83, 86. Orzeł z jabłkıem i berłem w szponach, k. 87, 96. Inicjały S, k. 88 i G C S, k. 90. Inicjały I V, k. 102, 104. Lilia, k. 105, 106. Piękny jeleń w biegu, poniżej inicjały A D T i napis: Soczewka, k. 108, 122, 125. Inicjały J F N, k. 134, 137. W ozdobnym owalu portret zapewne generała (widoczny epolet, na kołnierzu dwa paski), w owalu napis trudny do odcyfrowania, k. 135, 136. Nazwa: Jeziorna, • k. 138, 139. Nazwa: In Omsk ale może być również Smoleńsk, k. 145, 148. Tarcza herbowa $\mathrm{z}$ koroną książęcą i inicjałem $\mathrm{F} R \mathrm{u}$ spodu, k. 146, 147. Inicjały: G B, ponizej nazwa: Piaski, k. 149, 176. Inicjał $\mathrm{I}$, pod nim zapewne nazwisko: Sopel z inicjałami W T u spodu, k. 178, 179. W ozdobnym owalu 
portret mężczyzny z bujną fryzurą i bakami, k. 177, 180. Nazw1sko: I Zenger, k. 185, 187. W owalu $\mathrm{z}$ dwóch gałązek $\mathrm{z}$ liśćmi i kwiatami plaster miodu, poniżej napis: Honı, k. 199, 204. Nazwisko: C \& I Honig, k. 200, 203. Tarcza herbowa z koroną pıęcıopałkową zakończoną lilıą, w polu duża lilia, ponıżej inicjał I A, k. 206, 207. Ozdobny inıcjał A W, k. 212, 213. Nazwisko: D \& C Blauw, k. 232, 233. Tarcza herbowa $\mathrm{z}$ koroną pięciopałkową, w polu róg myśliwski na taśmie, poniżej nazwısko: D\& C Blauw. k. 231, 234. Nazwa: Kamow, poniżej inicjały T D, k. 217, 220.

Proweniencja: Biblioteka OO.Kapucynów w Sẹdziszowie.

S 27. Pol. XVIII-XIX w. $21 \times 13 \mathrm{~cm}$. K. 442. Bez opr.

Kazania niedzielne, świąteczne i okolicznościowe.

Inc.: $k$. 1: „Lubo ta obietnica Zbawiciela naszego szczególniej X za powierzone wychowanie i edukacje w królestwie niebieskim. Amen", k. 441.

Kazania różnych kapucynów $\mathrm{z}$ prowincji polskiej i galıcyjskıej. Karty niezapisane: $14 \mathrm{v}, 20,26,59 \mathrm{v}, 82 \mathrm{v}, 83,89,97 \mathrm{r}, 103 \mathrm{r}, 115,12 \mathrm{~s} v, 123,137$, $171 \mathrm{v}, 177,185 \mathrm{v}, 191 \mathrm{v}, 197 \mathrm{v}, 209 \mathrm{v}, 213 \mathrm{v}, 215,235,241 \mathrm{v}, 301 \mathrm{v}, 302,303$, $329-331,347 \mathrm{v}, 355 \mathrm{v}, 375 \mathrm{r}, 397,405,412,413,426 \mathrm{v}, 441 \mathrm{v}, 442$. Dostrzeżone zapiskı: k. 8v: „Nowe Miasto nad Pilicą 1857 r.“; k. 66: „u XX. Augustlianów] 1797 w Krakowe“; k. 90: „Varsavıae“; k. 98: „Kazanie na św Zygmunta w Pniowie“; k. 157v: „Br. Herkulan“; k. 191: ,1797“; k. 213: „Ks. Fabianıego“; k. 324: „w Odrzykoniu“; k. 375: „Fr. Xaverıus Barszczewski"; Od k. 70a-70g wszyty druk polski z fragmentamı kazanı. K. 426 podwójna (426a).

Składki: 62. 34 ma 2 k. Binıony 8, 9, 10, 13, 23, 31, 33, 36, 44, 46, 47, 51. Terniony $2-6,11,12,15,16-18,21,26,27,29,30,38,45,59$. Kwaterniony $1,7,14,17,20,22,25,28,32,35,37,39,40,41,43,48-50,52-55$, $57,58,60,61,62$. Seksterniony 19, 24. Septentrion 56. 42 ma $26 \mathrm{k}$.

Filigrany: fragment kotwicy, k. 21, 83. Nazwısko: C \& I Honıg, k. 42, 45. Nazwisko: J Müller, k. 116, 123. Miejscowość: Karlsthal, k. 117, 122. Nazwa kraju: Kl Morau, k. 133, 134. Inicjały $S$ A, k. 140. Inicjały $J R$ i fragment nieczytelnego napisu, k. 142, 145̄. Inicjały J WPI, k. 178. Fragment dwóch skrzyżowanych gałęzi, k. 188. Nazwa: Mirolach (?), k. 193, 196. Fragment polskıego orła, k. 214, 215. Nazwa: Mürau ı ponıżej ınicjały J S, k. 228, 235. Stojący jeleń $z$ napisem: Sopel i inıjałem $W$ T ponızej, k. 24:1, 247. Stylizowane drzewo (śwlerk), k. 243, 248. Napis Muct, k. 267. Inicjały A I H, k. 292, 303. Tarcza herbowa z orłem dwugłowym, k. 301, 302. Nazwisko: C C Geipel, k. 296, 297, 298, 299. Napıs: J Wbis, k. 327. Nazwa: Friedenthal, k. 355, 356. Inicjaly W K, k. 354, 357. Nazwa kraju: Kl Morau, k. 363, 364.

Proweniencja: Biblioteka OO. Kapucynów w Sẹdziszowie.

\section{LITURGIKA}

S 28. Eac., pol. 1730. $13 \times 7 \mathrm{~cm}$. K. 123. Opr. sk. wsp.

„Benedictiones... secundum Rituale Romanum. Anno Domini 1730. Ad usum Fratrum Reformatorum:"

Inc.: k. 10: „1mo habeat firmam fidem. 2do eliciat actum X emittant angelorum atque persolvant salvator mundi. Quis vivis...", k. 100. 
Na k. 98: „Benedictio generalis“, od k. 99-100r „Incipiunt varıa orationes pro Capucınıs necessarıae" w jęz. polskım. Na tylnej wewnętrznej okładce przepisy gospodarcze. Reklamanty. Paginacja oryginalna: nlb. 24, 168, nlb. 49. Karty niezapisane: 1v, 2, 3, 4v, 5, 9v, 11v, 12, 13, 98v, 100v-123. „Index benedictionum", k. 6--9. Tytul rubrykowany w ozdobnej ramce marginalnej. Rękopis rubrykowany.

Składki: 13. Kwaterniony 1-9. Kwinternıon 10. Seksterniony 11-13.

Filigrany: fragment niezıdentyfikowanego filigranu w prawym górnym rogu karty.

Oprawa w tekturę i sk. cıelęcą barwıoną na brązowo. Grzbiet wzmocnıony paskamı płóciennymi zaklejanymi pod okładką. Na oprawıe ramka dwulınıjna z krzyżem na przekątni; pola między tym wypełnione tłokamı wycıskanymı na clemno $\mathrm{z}$ wizerunkamı śwę̨tych, mało już wyraźnych, rozỉożonymi nieregularnie ( $\mathrm{z}$ końca XV w.). Grzbıet w dwóch polach zamalowany farbą olejną, żółtą. Szycie na 2 więzy. Kapitałka szyta.

Proweniencja: 1. „Praecipue ad usum Patris Benedicti Hinal". Napis na k. 4.

2. Bibliateka OO. Kapucynów w Sędziszowie.

S 29. Łac., pol. I pot. XVIII w. $12 \times 7.5 \mathrm{~cm}$. K. 168. Opr. sk. wsp. Preces.

Inc.: k. 2: „Nos vero ad maiorem vocati vitam $\mathrm{X}$ i królujesz na wieki wieków. Amen", k. $155 \mathrm{v}$.

Kolumna tekstowa w podwójnej, czarnej ramce margınalnej. Paginacja oryginalna: nlb. 2, 308, nlb. 6. Reklamanty.

Składki: $19 \mathrm{kwaternionów} \mathrm{lecz} 16$ I 19 bez $1 \mathrm{k}$.

Filıgrany: fragment tarczy herbowej w dolnej częścı karty z częścıą nazwiska: D \&, k. 83 oraz: Blauw, k. 106.

Oprawa $w$ tekturę szarą obciągniętą sk. cielęcą, zabarwioną na czarno. Oprawa bardzo silnie zniszczona a resztki sk. posiekane przez kornikı. Szycle na 3 sznurkı. Brzegi nakrapıane na czerwono. Wyklejka - papıer czerpany, grzebieniowy.

Proweniencja: Biblioteka OO. Kapucynów w Sędziszowie.

S 30. Łac. 1791. $15.5 \times 9.5 \mathrm{~cm}$. K. 356. Opr. sk. wsp.

„Missale iuxta $R$ [itum] S[anctae] R[omanae] E[cilesiae] pro comrodo viae A. V.P. Ubaldi ${ }^{13}$ Capucini, concionatoris, mpp. 1791 a Sędziszów“.

Inc.: k. 4: "Ad te levavi animam meam: Deus meus $X$ et in tuorum sede laetantium constituas redemptorem". Wyklejka tylna.

Mszal podróżny. Tytuł powtórzony na k. 233. Paginacja oryginalna: nlb. 6, 464, nlb. 52, 192. Trzy pierwsze karty to wyklejka i $2 \mathrm{k}$. ochronne. Karty niezapisane: $1 \mathrm{v}, 2 \mathrm{v}, 3,233 \mathrm{v}, 234,235$. Rubrykowany. Tytuły i podtytuły rozdzıłałów wykonane pismem $\mathrm{w}$ formie liter drukowanych. Na k. $249 \mathrm{v}$ wlepiony sztych współczesny przedstawiający ukrzyżowanego Chrystusa. Na k. 2 podpisy: „P. Vincentıus a Grodzisko, fr. Ceslaus, Drajewicz“.

134 Ur. 16 I 1743, do zak. wstąpił 1764, zm. 30 IX $1792 \mathrm{w}$ Sędzıszowle, - CPP nr 312; Mortuologium, jw. 
Składki: 47 kwaterniony. 33134 bez $1 \mathrm{k}$. karty.

Filıgrany: fragment niezıdentyfikowanego filigranu w gómej lewej części

Oprawa w deski obciągnięte w sk. cielęcą, zabarwioną na brązowo. Szycie na 5 więzów. Sznurkı przeciągane przez deski. Koło więzów oraz na oprawie frontowej \& tylnej odcıśnięte na ciemno linıe podwójne. Slady rzemyków z okuciem do zapinania. Kapitałka szyta. Brzegı czerwone.

Proweniencja: 1. O. Ubald Mańkowski.

2. Ks. Benedykt Krawczycki z Gorzyc. Napis na k. tytułowej.

3. Biblioteka OO. Kapucynów w Sędzilszowie.

S 31. Łac. II pot. XVIII w. $16.5 \times 11 \mathrm{~cm}$. K. 44. Bez opr.

Lekcje brewiarzowe.

Inc.: k. 1: "Gabriel Angelus apparuit Zachariae $\mathrm{X}$ vita sancte tunctus, atque sacramentis", k. 44.

Fragment większy z brewiarza. Reklamanty. Paginacja oryginalna: 17-106. Wykonany na kartach poliniowanych ołówkiem, pismem w formie liter drukowanych. K. 41 niezapisana. Rubrykowany.

Składkl: 6 . Ternion 6 bez $3 \mathrm{k}$. Pozostale kwaterniony. Kustosze literowe od A-Z.

Filigranów nie ma.

$\mathrm{Z}$ dawnej oprawy pozostało tylko szycie na 3 sznurki.

Proweniencja: Biblioteka OO.Kapucynów w Sẹdziszowie.

S 32. Łac. II pot. XVIII w. $20 \times 15.5 \mathrm{~cm}$. K. 128. Opr. tekt. wsp.

„Rubrum breviarii personis in statu ecclesiastico existentibus ac ad illum aspirantibus perutile. In quo non solum continetur quis ordo sit in breviario, sed insuper traditur modus facillimus absolvendarum Missarum, quae, quando et quomodo dici debeant. Insuper variis decretis S. R. Congregationis ad removendam difficultatem plurimorum rerum in illo contentarum illustratum et in lucem data opera cuiusdam personae in statu ecclesiastico existentis eductum".

Inc.: k. 2: "1. Breviarium definitur: compendium breve, s[acr]ae scripturae $X$ faculatibus in civitate et dioecesi - tantum", k. $123 \mathrm{v}$.

Podręcznik do rubryk mszalnych $i$ brewiarzowych opracowany po r. 1739 z dodatkamı po r. 1766. Reklamanty. Paginacja orygınalna: nlb. 2, 109, nlb. 2, 67, nlb. 4, 202, nlb. 9. Karty niezapısane: 1v, 57, 91v, 92, 93, 119v, 124-128. Druga ręka od k. $120-123 \mathrm{v}$. W tytule nlektóre słowa rubrykowane, jak również w tekście nagłówki a nawet pewne zdania. Słowa i dłuższe myśli często podkreślone czerwonym inkaustem. Między k. 91 a 92 wklejony druk z rubryceli: „Tabulae directivae pro SS. Missae Officio celebrando“, k. 313 (dwie karty druku).

Składki trudne do policzenıa.

Filigrany: 1nicjały: I I, wysokı krzyżyk i inicjały I G, k. 57, 93.

Oprawa twarda w tekturę szarą, obciągnięta cała papierem czerpanym, zdobionym techniką drzeworytniczą o motywach ludowych $z$ drobnych kwiatków w dwóch kolorach. Pod papierem, na uszkodzonej części okładki fron- 
towej, ślady poprzedniej oprawy, również w papier zdcbiony drzeworytniczo o odmiennych roślinnych rysunkach. Grzbiet wzmocniony szarym płótnem, podniszczony. Szycie na 4 sznurki. Wyklejka z czerpanego prążkowanego papieru, także zadrukowana drzeworytem w barwne kwıaty. Wyklejka ta utrzymała się tylko na okładce frontowej i tylnej. Kapitałka szyta ręcznie. Brzeg1 czerwone

Proweniencja: Biblioteka OO. Kapucynów w Sędziszowie. Sygn.: Nr 53 na tylnej wyklejce.

S 33. Eac., pol. II pot. XVIII w. $15 \times 11 \mathrm{~cm}$. K. 121. Opr. sk. wsp. Modilitewnik dla zakonnika.

Inc.: k. 1: „3tio. Singulis diebus vel mane vel vespere $\mathrm{X}$ będzie $\dot{z} y-$ wotem moim o Jezu mój. Amen", k. 121.

Zdefektowany rękopis bez początku. Pismo kilku rąk. Każda strona znaczona w górnym marginesie inıcjałami: JMJ, a od $k$. 88 krzyżykiem. Ostatnıe składki prawıe luźne. Wyklejka drukowana z r. 1757 (k. 112) pochodzı z drukamı w Poczajowie.

Składkı: 15. Biniony 7, 8. Terniony 1, 3. Kwaterniony 4, 5 bez $2 \mathrm{k}$. wyciętych, 9-14. Kwinternion 2. Sekstermon 15 bez $\frac{1}{2} \mathrm{k}$. Składka 6 ma $18 \mathrm{k}$.

Filigrany: fragment filigranu w lewym górnym rogu karty.

Oprawa półtwarda w tekturę sklejaną, obciągnięta sk. barwioną na czarno. Grzbiet był silnie zniszczony przez korniki a potem, dla wzmocnienia, oklejony paskiem szarego płótna i znowu nadweręzony. Oprawa silnıe zniszczona. Szycle 2 sznurki; $z$ więzów pozostały tylko ślady. Wyklejek brak.

Proweniencja: Biblioteka OO. Kapucynów w Sẹdziszowie.

\section{TEOLOGIA ASCETYCZNA I MISTYCZNA}

S 34. Pol. 1759. $15.5 \times 9 \mathrm{~cm}$. K. 357. Opr. ptsk. wsp.

Rozmyślania na każdy dzień roku.

Inc.: $\mathrm{k} .1$ : „1. Gotuje się Pan nad pany do nas $\mathrm{X}$ aby się adrobinami obłud stworzonych od. twoich godnie odwodziło", k. $357 \mathrm{v}$.

Zbiór rozmyślań ascetycznych. Reklamanty. Karty niezapisane: 2, 3, 5-8, $10,11,13-17,20-22,24,25,27,28,30-35,50-57,209-214,224,226-227$, $229,231,233,234,237,238,240,299,302,305-312, \$ 42,349$. Każda karta w górnym marginesie znaczona krzyżykiem. Glosy margınalne. W tekście liczne przekreślenıa i podkreślenia.

Składki: 48. Biniony 2, 3, 4, 8, 29, 45. Terniony 1, 5, 7, 10, 12, 14, 16, 18. Kwinterniony 11, 13, 15, 19. Pozostałe kwaterniony lecz 27 i 45 bez 1 k., 46 bez $6 \mathrm{k}, 39+1 \mathrm{k}$.

Filigrany: fragment filigranu w lewym górnym rogu karty.

Oprawa półmiękka w tekturę szmacianą 1 płsk. Brzeg i rogı skórzane. Sk. barwiona na brązowo. Okładki obciągnıete papierem klajstrowym, czerpanym. Szycie na 3 sznurkd. Oprawa uszkodzona.

Proweniencja: 1. Ks. Kazimierz Wiolff.

2. „Ex Bibliotheca P. P. Capucinorum Conventus Sędziszoviensis. Hic liber donatus est a Perillustri Rndo Wolff Casimiro, Notario Apostolico, Praepasito Głogoviensi. Anno 1759". Napis na wylklejce fmontowej. 
S 35. Łac. $1782-1783.15 .5 \times 10 \mathrm{~cm}$. K. 44. Opr. sk. wsp.

„Rudimenta religiosa, quibus novitii et neoreligiosi pie erudiuntur in quotidianis exercitiis spiritualibus perficiendis. Libellus praesens complectit omnia et singula exercitia spiritualia in religione nostra capucinica usitata, nec non salutaria documenta, pia monita, et vitae regularis observantia. A P. Anania Capucino conscriptus, Lubartoviae a. D. 1782 die 30 aprilis. Professus 1783 eodem die qui supra ad S. Laurentium M[artyrem]".

Inc.: k. 2: "Charissimi fratres trado vobis rudimenta religiosa $\mathrm{X}$ deinde aspergitur infirmus aqua benedicta", k. 44v.

Podręcznik dla zakonnika nowicjusza kapucyńskiego, opracowany przez o. Kajetana Cyglera, a napisany pod dyktandem przez Ananiasza Zelinke ${ }^{135}$, Czecha. Nowicjat odbywal on pod kierunkiem mistrza nowicjatu o. Kajetana Cyglera. „Haec omnia... sub A. V. P. Caietano bene promerito vicario ac novitorium magistro. F. Ananias novitıus", k. 35. Biografia o. Ananiasza znajduje się na k. $40 \mathrm{v}-43$.

Składkı: 8. Binıony 5, 7. Pozostałe terniony ale w ostatnıej składce $2 \mathrm{k}$. sklejone razem (k. 40).

Filigrany: Matka $\mathrm{z}$ Dzıecıątkıem $\mathrm{w}$ koronach $\mathrm{w}$ otoku promıeni, k. 1. Zdobnik z krzyzem 1 inicjały I G H, k. 30, 33. Data 1783, k. 7.

Oprawa w całą sk. cielęcą, barwioną na brązowo. Na grzbiecie ślady złoconych bordiur. Szycie na 3 sznurkı. Wyklejka z papieru czerpanego grzebienıowego pozostała tylko na okładce.

Proweniencja: 1. O. Ananiasz Zelinkia.

2. Biblioteka OO. Kapucynów w Sędziszowie.

S 36. Eac. II pot. XVIII w. $17.5 \times 12 \mathrm{~cm}$. K. 55. Opr. sk. wsp.

"Tubae clangor ad religiosum".

Inc.: $\mathrm{k}$. 1: „Ausculta Deum tuum o religiose in tempore $\mathrm{X}$ medira haec sunt praecepta, constitutiones", k. 55.

Kodeks bez karty tytułowej i końca. Obecny tytuł wykonany ołówkıem na odwrocie okładki frontowej. Do k. 48 pisany w ramce marginalnej pierwszą ręką. Dalszy tekst w kolumnie bez ramki drugą ręką. Reklamanty tylko w drugiej częścı. Paginacja oryginalna: 94, nlb. 15.

Składkı: 7 kwaternıonów lecz 7 bez $1 \mathrm{k}$.

Filigrany: fragment filigranu w lewej górnej częśc1 karty.

Oprawa w tekturkę szarą 1 calą w sk. c1elęcą, barwioną na brązowo. Okładki w górnej części przy grzbiecıe pęknięte. Szycie na 2 tasiemkı.

Proweniencja: Biblioteka OO. Kapucynów w Sẹdziszowie.

S 37. Łac. II pot. XVIII w. $15.5 \times 9 \mathrm{~cm}$. K. 68. Opr. sk. wsp.

„Locutio Dei ad cor religiosi in sacra per decem vel octo dies exercitiorum spiritualium solitudine. Annuatim commorantis per dies sin-

195 Ur. 19 III 1763, do zák. Wstąpił 1782, zm. 18 XII 1818 w Krosinie. - CPP nr 398; Mortuologium, Jw. 
gulos digesta a P. Daniele Pawlowski ${ }^{136}$ Polono Societatis Jesu theologo. Anno... 1673. Calisii typis Colleg[ii] Soc. Jesu“". Dopisek inną ręką: 1677 .

Inc.: k. 5: „Concessa primum a Paulo 5 anno 1600 die 23 maii $X$ oportet nos intrare in regnum Dei. Finis sententiarum", k. 67v.

Kopia druku sporządzona przez nieznanego skryptora. Tytul i kolumny tekstowe $\mathrm{w}$ ramce margınalnej. Każda strona w górnym marginesie znaczona małym krzyżykiem. Dolna część karty tytułowej doklejona późnıej. Blok rękopisu w górnej części lekko zawilgocony. Reklamanty. Glosy marginalne. Podkreślenia w tekście.

Składki: 9. Binion 9 bez $2 \mathrm{k}$. Ternion 2. Kwinternion 1. Pozostałe kwaterniony lecz $3+1 \mathrm{k}$.

Filıgrany: myślıwy na koniu, dmący w róg, k. 1. Fragmenty unnych filigranów niezidentyfikowane.

Oprawa w cienką, szarą tekturkę obciągniętą sk. cielęcą, barwıoną na brązowo. Ramka na oprawie frontowej i tylnej grubą linią tłoczona. Oprawa i grzbiet od wewnątrz zaatakowane silnie przez korniki. Szycie na 3 sznurki. Brzegı nakrapiane na niebiesko.

Proweniencja: Biblioteka OO. Kapucynów w Sędziszowie.

Uwagi: $W$ ręlkopisie od $\mathrm{k}$. $62 \mathrm{v}-67 \mathrm{v}$ dodano $\mathrm{w}$ jęz. lac. Wybór myśli z Naśladowania Chrystusa św. Tomasza a Kempis.

\section{BIBLISTYKA}

S 38. Łac. 1618-1619. $19.5 \times 16 \mathrm{~cm}$. K. 206. Opr. perg. wsp.

1. k. 2-205. "Commentarius in Genesim cum quaestionibus, controversiis de iustificatione et bonis operibus ac de sacrosancto sacrificio Missae. Scriptus ab Adamo Peski in Collegio Posnaniensi Societatis Jesu s. theologiae auditore".

Inc.: k. 3: „Respondeo. Omnes Hebraeos, Graecos et Latinos X Missam non esset vulgari lingua celebrandam", k. 204v.

2. k. 206. "Assertiones ex controversiis de iustificatione et bonis operibus". Jest to drukowane tezarium o wymiarach $36.5 \times 28.5 \mathrm{~cm}$.

Inc.: k. 206: Iustificationis nomen non est tantum fori $\mathrm{X}$ consequitur Christianis non esse interdictas divitias".

Szkoła: Kolegium jezuitów w Poznaniu. Prof.: o. Baltazar Wolborius ${ }^{137}$. Skryptor: Adam Pęski.

Karty niezapisane: $93-98 v, 155 v, 156$, z05. Karta ochronna pierwsza czysta, na drugiej tytuł. Tytuł wypısany w większej części majuskuła, pierwsze słowo tytułu, nazwisko i imię oraz S. J. rubrykowane $w$ całości. W tekście rubrykowane tytuły, podtytuły, nieraz zdania, słowa i początek słów. Rzadkie glosy marginalne. $\mathrm{Na}$ końcu rękopisu wlepiony druk j. w. zawierający 20 tez teologicznych, ujęty w piękną renesansową ramkę z napisem u dołu: „Defendentur

13. Ks. J. B r o w n, Jw. s. 309-310; Enc. Orgelbr XX 487; Estr. XXIV 160-164; Jo c h e r (wykaz licznych pozycji); Es tr. II 257.

137 Ur. 1571 (2), do zak. Wstąpil 1597, 2m. 29 VIII 1638 w Poznanı. - ArSI, Necrol. Poloniae (1612-1700) f. 329 . 
publice in Collegıo Posnaniensi Societatis Jesu a religiosis eiusdem Societ[atis]. Anno 1619. Mense iunio. Die... Hora...". Na k. 61-69, w górnym i dolnym brzegu ślady lekkiego zawilgocenia. Poza tym kodeks bardzo dobrze zachowany.

Składki: 25. Ternıony 1, 3, 5, 7, 9, 11. Kwinterniony 2, 6, 12 bez 2 k., 19. Seksterniony 4, 8. Pozostałe kwaterniony ale 25 bez $2 \mathrm{k}$.

Filigrany: tarcza herbowa z koroną, w polu jeleń w skoku, k. 95, 96.

Oprawa w szarą tekture obciagniętą pergaminem. Na grzbiecie tytul tłoczony czarną farbą w rameczce i takaż ramka o dwóch liniach ze stemplem kwiatowym w rogach. Na froncie okładki odbity tłok z postacią Chrystusa ukrzyżowanego i klęczącą Matką Bożą. Na tylnej okładice postać Matkı Bożej z Dzieciątkıem Jezus wspartej o półksıężyc. Boki okładek zagięte do środka dla ochrony papieru. Szycie na 3 tasiemki pergaminowe, przeciągane przez grzbıet i składkę. Kapıtałka szyta ręcznı. Później dodane dwie pary tasiemek płóciennych. Brzegi czerwone.

Proweniencja: 1. Adam Pęsiki. Pormań.

2. "Patrum Cápucinorum Conventus Sędziszoviensis". Napis na k. tytułowej. Pieczątika podłużna na k. tytułowej, 99, 204v.

S 39. Eac., pol. okoto 1620. $19.5 \times 16 \mathrm{~cm}$. K. 164. Opr. perg. wsp.

„Explanationes in cantica canticorum Salomonis et in Epistolam D. Pauli ad Ephesios. His accesserunt quaestiones controversae: de statu et votis religiosorum hominum, Deo, praesentia Christi in eucharistia ac de ieiunio ab Adamo Pęski in Alma Academia Vilnensi exceptae, manuque propria conscriptae. Interpositas his explanationibus et controversiis, conciones aliquot invenies, ne spatium chartarum quod remanserat, vacuum daretur".

Inc.: k. 3: "Consilio natae venit vi consuetudinem $\mathrm{X}$ extra ieiunii tempus, is et utamur", k. $164 \mathrm{v}$.

Szkoła: Akademia w Wilnie. Profesor: o. Konstanty Szyrwid ${ }^{138}$, jezuita. Skryptor: Adam Pęski.

Kazania od k. 97-129v skromnie rubrykowane. Karty niezapisane: $2 \mathrm{v}$, 46, 47, 137. Po k. 96 karta wyrwana. Glosy marginalne. Układ pisma w dwóch kolumnach z zachowaniem szerokich margınesów. Tytuł rękopisu, wypisany majuskuła, rubrykowany (minia), podobne nagłówkı rozdzıałów, całe zdania, niektóre słowa, podkreślenia $\mathrm{w}$ tekścıe. $\mathrm{W}$ wielu wypadkach minia poplamiła sąsiednıe karty. Na k. 129v naklejony zdobnik. Slady zawilgocenia - większe w dolnym brzegu, mniejsze w górnym.

Składkı: 22. Terniony 7, 9, 11 bez 2 k., 16, 22 bez $2 \mathrm{k}$. Kwinterniony $8,10,15$. Pozostałe kwaterniony ale 6 bez $2 \mathrm{k}$.

Filigrany: tarcza herbowa, w polu podkowa zakończona krzyżem, k. 2. W polu tarczy herbowej orzel, k. 153, 160.

Oprawa półtwarda $\mathrm{w}$ pergamin wycıety $\mathrm{z}$ kodeksu średniowiecznego, z czytelnym tekstem, nutami i kolorowanymi inicjałamı (minia, błękit). Szycie na 3 tasiemki pergaminowe, przecıagane w grzbiecie 1 przez okładkę

${ }_{193}$ Ur, 1564, do zak. wstąpir 1598, zm. 23 VIII 1631 w Wilnue. - Ks. J. B r o w n, Jw. s. 399400; Enc. Now. XXVIII 134-135; Enc. Orgelbr. XXIV 875-876; Es t r. XXX 357-361; L. F in k el III poz. 1872; J o c h e r nr 717, 718, 4457, 4625,4626, 5169; G. K o r b u t, Jw. T, 1 s. 290; Ks St. $\mathrm{Z}$ ał ę skl, JW. T. 1 s. 96. 
a ponadto wzmocnione dwiema tasıemkami płóciennymi. Kapitałka szyta ręcznie. Oprawa dobrze zachowana.

Proweniencja: 1. Adam Pesiki.

2. „Ex Bibliotheca P.P. Capucinorum Conventus Sędziszoviensis". Napis na k. tytułowej. Pieczątka poidłuzna na k. 2, 48, 97, 164v.

S 40. Eac. I pol. XIX w. $22.5 \times 18 \mathrm{~cm}$. K. 178. Opr. brosz.

"Hermeneuthica biblica".

Inc.: k. 1: "Prolegomena $\S 1$. observanda. Quia s. scriptura X obtigerat circa annum salutis $96^{\circ}$, k. $178 \mathrm{v}$.

Tytuł grzbietowy: „Hermeneuthica \& introductio". Kartty niezapisane: $139 \mathrm{v}, 140$.

Składki: 16. 1 ma $30 \mathrm{k} .+1$ dolepiona. Kwaterniony $2-4,5+1 \mathrm{k}$. 11-16. Seksternion 10. Okterniony 6-9.

Filigrany: fragment gwiazdy 1 nazwisko: I Hicki, k. 178.

Oprawa broszurowa. Na grzbiecie ubytek papieru. Szycie na 2 sznurki.

Proweniencja: 1. „Leopoli apud Minoriticos. Fr. J[osephus] Krzysik". Napis na okładce tyinej.

2. Biblioteka OO. Kapucynów w Sędziszowie. Piecząlka podłużna, k. 1, 85, 167.

S 41. Łac. I poł. XIX w. $24.5 \times 19.5 \mathrm{~cm}$. K. 48. Bez opr.

Hermeneuthica biblica.

Inc.: $\mathrm{k}$. 1: „Probat autentia et integritas s. scripturae $\mathrm{X}$ aeternam suam salutem operari solent. Finis $1 \mathrm{mi}$ anni", k. $48 \mathrm{v}$.

Część skryptu teologicznego, zawierającego wykłady z biblistykı drugiego semestru. Reklamanty. Na marginesach numerowane paragrafy. Liczne podkreślenia w tekścıe.

Składkı: 12 binionów. Kustosze literowe od $\mathrm{K}-\mathrm{X}$.

Filigrany: orzeł $\mathrm{w}$ koronı $\mathrm{z}$ jablkıem 1 berłem $\mathrm{w}$ szponach. W polu słońce 1 krzyż, k. 5. Nazwa: Buczcaz (prawdopodobnie powinno być Buczacz). Inicjały: F R W Z, k. 45, 46, 48.

Broszura szyta.

Proweniencja: Biblioteka OO. Kapucynów w Sędziszowie.

\section{HISTORIA KOSCIOEA}

S 42. Łac. 1643. $19.5 \times 15 \mathrm{~cm}$. K. 189. Opr. sk. wsp.

„Historia ecclesiastica“.

Inc.: k. 1: ,fuisset gratia corruptus Sanctus Augustinus X quod caritatem violat. 16 iulii a. $1643^{66}, \mathrm{k} .181$.

Kodeks obejmuje historie Koścıła oraz zapiski o treścı ascetycznej. Pagina.cja oryginalna od $\mathrm{s}$. 103-503, nlb. 16. Nielıczne glosy marginalne. Tytułu brak, jak również stron 1-102. Brakujące składkı zostały prawdopodobnie wydarte. Obecny tytuł wykonany ołówkiem kopjowym przez o. Zenona Gorlickiego na wyklejce okładkı frontowej. Na k. 142 napis: „A. 1643 Cracoviae in S. Barbara". (Jezuici). Blok rękopısu w górnym brzegu bardzo zniszczony przez wilgoć 1 pleśń a także częścıowo zmurszały.

Składki: 24 kwaterniony, 1 bez 1 k., 24 bez $3 \mathrm{k}$. 
Fillgrany: królik lub, zając w otoku, k. 185, 187.

Oprawa w tekture szmacianą. Sk. biała barania, z bogatym ornamentem o układzie renesansowym i tłokamı rolek z główkamı postaci mitologicznych. W zwierciadle $\mathrm{w}$ narożnikach stempel filigranowy o motywach roślinnych. $W$ pośrodku duży tłok owalny $z$ inicjałem IHS $w$ obwódce $z$ promieni. Ornamenty powyższe tłoczone na sucho. W grzbiecıe oraz w górnej części okładki frontowej brak skóry. Szycie na 3 sznurki, wzmocnione w grzbiecie paskami pergamınowymi. Ślady dwóch par rzemyków skórzanych do wiązania. Kapitałka wyszywana. Brzeg1 czerwone.

Proweniencja: Biblioteka OO. Kapucynów w Sędziszowie.

S 43. Eac. 1833. $21.5 \times 17.5 \mathrm{~cm} . K$. 174. Opr. brosz. wsp. „Historia ecclesiastica“.

Inc.: k. 1: „Per factum in genere theologi X quod institutum instrumentum pauperum puerorum praecipit“" Wyklejka tylna.

Blok rękopısu wykonany na sıwym papierze prążkowanym. Glosy marginalne, interlinearne i poprawki w tekście. Koniec rękopisu na wyklejce tylnej.

Składki: 11. Seksternion 1. Pozostałe okterniony, lecz 11 bez $1 \mathrm{k}$.

Filigrany: napis N 2, k. 95.

Oprawa broszurowa. Grzbiet obciągnıęty szarym płótnem. Okładki z grubego papieru czerpanego. Napis tytułowy na grzbiecie lekko zatarty. Szycie na 2 sznurki.

Proweniencja: 1. O. Józef Krzysikiewicz, kapucyn.

2. „Ad usum Conventus Capucinorum Sendziszoviae 1833 in noviciatu“. Napis na wyklejce frontowej.

\section{FILOZOFIA SCHOLASTYCZNA}

S 44. Eac. 1712 (?). $18.5 \times 15 \mathrm{~cm} . K, 371$. Bez opr.

Philosophia scholastica.

Inc.: k. 1: „Arguitur 1mo. Causa ad cognitionem rerum X id est logicam, physicam, metaphysicam finivimus“, k. $371 \mathrm{v}$.

Treść: druga część logiki od k. 191, trzecia od k. 221, metafizyka od k. 289. Ponadto "De modo in disputationibus servando" od k. $284 \mathrm{v}-287$.

Szkoła: prawdopodobnie Akademia Krakowska. Skryptor: Antoni Krząnowski.

Paginacja oryginalna: $2-9,12-570$, dalsze strony bez paginacji. Glosy interlinearne. Poprawkı w tekście. Szerokie zastosowanie skrótów. Kodeks bez początku.

Składki: 29. Ternion 1 bez 2 k. Okterniony 3-7, 3, 16, 21, 23. Pozostałe seksterniony lecz 12 bez $3 \mathrm{k}$, 29 bez $3 \mathrm{k}$.

Filigrany: orzeł polski, pod num zdobnik, k. 10, 11. Gryf w polu herbowym, k. 142, 144. Tarcza herbowa z liliami, k. 280, 281. Tarcza herbowa, k. 252, 254. Lilia, k. 320, 321.

Księga bez oprawy i wyklejkı. Na grzbiecıe ślad zaciaggnięcia skóry i wzmocnienia paskami pergaminowymi. Szycie na 3 rzemienle. Brzegi nakrapiane na czerwono. 
Proweniencja: 1. „Ex Libris M. Antonii Krzanowski S. Th. D. Clepardiensis S. Floriani Prepositi". Napis na k. 1.

2. Biblioteka OO. Kapucynów w Krakowie. Sygn.: LXXXVIII (o. Z. G.).

3. Biblioteka OO. Kapucynów w Sędziszowie.

S 45. Łac. 1751. $22 \times 17 \mathrm{~cm}$. K. 123. Opr. płsk. usp.

„Philosophia recentiorum".

Inc.: k. 2: „Philosophia est vox composita ex graeco $\mathrm{X}$ doctus est qui Dei voluntatem facit et suam voluntatem relinquit", k. 121v.

Szkoła: prawdopodobnie Kolegium pijarów.

Pismo jednej ręki $\mathrm{z}$ wyjątkiem k. 122. Na marginesach numery paragrafów. Na dolnym marginesie znak „verte", oznaczający kv. Rubrykowane tytuły rozdziałów na k. 1, 2. Rysunek 1 wykres "Schema oppositionis“ na k. 24. Na k. ochronnych $122 \mathrm{v}, 123$ i wyklejce tylnej znajduja się rysunki świętych wykonane ołówkiem. Na końcu kodeksu inskrypcja: „Finita prıdie S. Josephi anno Dnı 1751".

Składki: 11. Ternion $11+3 \mathrm{k}$. ochronne. Kwinterniony 4, 7. Pozostałe seksterniony ale $1 \mathrm{bez} 1 \mathrm{k}$.

Filigrany: kompozycja roślınna $z$ napisem: Nev Brag Mas, k. 122, 123. $\mathrm{Na}$ tylnej wyklejce fragment filigranu: Matka Boska z Dzıecıątkıem w otoku promieni.

Oprawa półmiękka. Grzbiet obcıągnięty sk. barwioną na brązowo. Okładki z tektury brązowej miękkiej, obcıągniętej papierem klajstrowym ręcznıe kolorowanym. Szycie na 3 sznurki.

Proweniencja: „Bibliotheca PP. Capucinorum Sędziszoviensium“. k. 1.

S 46. Łac. II poł. XVIII w. $21 \times 17 \mathrm{~cm}$. K. 215. Opr. płsk. wsp.

Philosophia universalis.

Inc.: k. 1: „ideo natura divina non est $\mathrm{X}$ in motu progressivo facere morulas non item clanem", k. 215.

Kodeks bez początku i końca. $\mathrm{Na}$ marginesach numery paragrafów. Rzadkie reklamanty. Kilka składek z początku i końca wyrwano. Pozostały liczne strzępy. Karta niezapisana 193v. Na k. 14 rysunek „arbor porphyriana“.

Składki: 21. Binıony 3, 12. Kwaterniony 5, 6, 10. Pozostałe seksterniony ale 1 bez $3 \mathrm{k}$., $2+1 \mathrm{k}$. a 21 ma tylko $5 \mathrm{k}$. W dolnych marginesach częśclowo zachowane kustosze liczbowe (początkowo liczby rzymskıe, później arabskie).

Filigrany: Matka Boska z Dziecıątkıem i inicjały HS, k. 177, 191, 193. Tarcza herbowa z koroną i inicjały MI, k. 101, 103.

Oprawa $w$ tekturę szarą, szmacianą. Grzbiet i rogi skórzane. Okładki obcıągnięte papierem klajstrowym barwionym na brązowo. Koło więzów i wzdłuż grzbietu grube line tłoczone na ciemno. Okładki podniszczone. Kapitałka szyta ręcznie.

Proweniencja: Biblioteka OO. Kapucynów w Sędziszowie.

S 47. Łac. I poz. XIX w. $21.5 \times 18.5 \mathrm{~cm}$. K. 94. Bez opr.

"Compendium ex tota physica generali et particulari".

Inc.: k. 1: „Physica nominis sui etymon a verbo graeco $\mathrm{X}$ destinata et amicti sunt per se puri spiritus", k. 94. 
Rękopis skkłada się $\mathrm{z}$ siwego papieru czerpanego. Pismo kilku rąk. Reklamanty. Glosy marginalne. Karta niezapisana: $193 \mathrm{v}$.

Proweniencja: Biblioteka OO.Kapucynów w Sẹdziszowie.

\section{RETORYKA}

S 48. Łac., pol. 1714. $20 \times 15.5 \mathrm{~cm}$. K. 370. Opr. sk. wsp.

1. k. 3---156. „Comitia rhetorica integritati status regni eloquentiae consulentia. Per reginam artium eloquentiam universis sui regni ordinibus intimata. Concordi omnium in libertate viventium eiusdem regnatricis oratoriae... confirmata. A malignis adversae partis interruptionibus per vigilantissimum Łaszczoviorum Leonem Illustrissimo Dno D. Alexandro Michaele de Łaszczow et Tuczapy Łaszcz Palatino Bełzensi senatoria fulgentem curuli, nec non palatinatus Bełzensis senatorem ac protectorem defensa praesidente mercurio decem sessionibus ab Illustribus ac Magnificis in Collegio Palatino Varensi Scho[larum] Piar[um] scholae rhetorices candidatis celebrata die $117 \mathrm{bris}$ anni 1714 . Inchoata in annum millesimum septingentesimum decimum quintum protrahenda".

Inc.: k. 5: „1. Oratio est argumenti per externum sermonem $\mathrm{X}$ accedant plura inferius de illis discurrenda“, k. 156.

2. k. 162-368v. ,,Sphaera Mercurii duodenis gradibus distincta, annuo rotatu cum sole decurrens in usum addictis eloquentiae mentibus expedita. In Collegio Varęsensi Scholar[um] Piarum anno... 1715 die 13 septembris in $1716^{\prime \prime}$.

Inc.: k. 163: „Nunquam magna vocalioris gloriae documenta $\mathrm{X}$ trophaea media super orbem ponam", k. $368 \mathrm{v}$.

Szkoła: Kclegium pijarów w Warężu. Profesorowie: o. Klaudiusz Krasnodębsk1 1 o. Maciej. Skryptor: Francıszek Kielarskı.

Reklamanty. Karty niezapisane: 1, 2, 3v, 6, 112v, 113-116, 156v, 157-161, $162 \mathrm{v}, 198 \mathrm{v}, 199,208 \mathrm{v}, 235 \mathrm{v}, 236-238,257 \mathrm{v}, 258,281-282,294,304,316$, $338 \mathrm{v}, 339,340,369,370$. Nieliczne numery paragrafów na marginesach. Glosy marginalne. Wyklejka frontowa wyrwana. Tytuł wykonany częściowo majuskułą w podwójnej ramce. W rogach znajdują się stylizowane kwiaty. Ddbicie negatywu tytułów na k. 1, 2, 159, 160, 161.

Składki: 52. 2, 20 po 2 k. Binıny 11, 21 bez 1 k., 34, 39, 41, 43, $49-51,52$ bez $2 \mathrm{k}$. Terniony 31, 35, 36, 40. Kwinterniony 1,22 bez $1 \mathrm{k}$., 23, 24, 27. Seksterniony 15, 37. Pozostałe kwaternjony.

Filigrany: pod grupą osób napis: ACAC, k. 157-160.

Oprawa $w$ tekturę szarą 1 całą sk. cielęcą, barwioną na brązowo. Szycie na 3 sznurki. Slady dwóch par rzemyków do wiązanıa. Kapitałka szyta dwukolorowa, białoczerwona.

Proweniencja: 1. „Scriptum sub PP Claudio et Mathia Scholar[um] Piar[um] in Collegio Varezensi annis supra praestatis ab illorum discipulo Francisco Kielarski".". Napis na wyklejce tylnej.

2. „Ex Bibliotheca PP. Capucinorum Sędzïszoviensium“. Napis na k. tytułowej. Sygn.: $\mathrm{nr} 37$. 
S 49. Łac., pol. $1742.19 .5 \times 16 \mathrm{~cm} . K$. 122. Opr. pisk. wsp.

1. k. 1-54. "Adagia polono latina“. (Tytuł tekstowy).

Inc.: k. 1: „Alboć daj alboć wydaj. Arma tenenti omnia $\mathrm{X}$ de male quaesitis non gaudet tertius haeres. Vulg. Złe omnes“, k. $54 \mathrm{v}$.

2. k. 55-122. „Adagia polono latina... Michael Podhorodecki".

Inc.: k. 55v: „Affekt nałóg pr̀zyrodzony, rzadko bywa zatajony $\mathrm{X}$ diugoletniego szczęścia był fundamentem", k. 122v.

Przysłowia i powiedzenia ułożone w. porządku alfabetycznym. Brak karty tytułowej. Należy jednak przypuszczać, że obydwa tytuły były identyczne. Autorem kodeksu jest IMichał Podhorodecki. Pierwsza częśc pozbawiona końca, na co wskazuje reklamant: „Złe omnes“, ale bez kontynuacji tekstu. Druga czesść została zakończona w r. 1742, o czym śwıadczy napis na k. 108v: ,Anno Dni 1742 die 1ma ıanuarii“. Reklamanty. Pierwsza część rękopisu i k. tytułowa drugıej części zawıerają kolumnę tekstową w podwójnej ramce marginesowej.

Składk1 23. Biniony 1-10,12, 13, 22, 23. Terniony 11, 17, 19, 20 bez $1 \mathrm{k} ., 21$ bez $1 \mathrm{k}$. Kwaterniony 15, 16. Kwinterniony 14, 18.

Filigrany: fragment nıezıdentyfikowanego filigranu w lewej górnej części karty.

Oprawa $w$ tekturę. Grzbiet i rogi obciaggnięte papierem czerpanym. Okładki obciągnięte papıerem klajstrowym z marmurkıem grzebieniowym na karagenie. Na grzbıecıe ślady malowanego ręcznıe tytułu. Szycie na 3 więzy.

Proweniencja: 1. Michał Podhorodecki.

2. "Josephi Jakubowski sacerd[otis]". Napis na wyklejce frontowej.

3. „Conventus Mariampolen[sis] PP. Capucinorum post fata J.R. D. Josephi Jakubowski vicedecani Stanisl[aopolensis] $1766^{\circ}$. Napis na k. 1.

4. Biblioteka OO. Kapucynów w Sędziszowie.

S 50. Łac., pol. $1761-1762.18 .5 \times 15.5 \mathrm{~cm}$. K. 199. Opr. ptsk. wsp.

1. k. 3-137. „Diphtongus inter umbrosas Heliconis oras aut super pindo gelidove in hemo geminam sub vocis vocalitatem spargens seu polono latina exercitia in academico Tarnoviensi Lycaeo Perilustris olim et Reverendissimi Dni Dni Adalberti Kaszewicz insignis Collegiatae Tarnoviensis scholastici praepositi et officialis Becensis ecclesiaeque parochialis in Jodlowa curati viride litteris et litteratis meritissimi fundatorisque munifici soluto ligatoque stylo per lintaeticas IM. Lucae Piorovii regulas M. Stanislai Michaelis Wątorski philosophiae doctorlis scholae poeseos professoris collecta. Iam vero scientifici profectus gratia mihi Michaeli Urbański in academico Tarnoviensi colonia Scholae poeseos alumno tradita anno pontificis saeculorum".

Inc.: k. 4: „Szczęść ci Boże na szybkolotnych Pegáza X hine illi qui lucem habitat inaccessibilem", k. 134v.

2. k. $137 \mathrm{v}-167$. „Lekarstwo na szkodliwe psa piekielnego użarcia najskuteczniejsze bogactwa umysłu i duszy nieoszacowane. Wyrok my- 
śli przedwiecznej najsławniejszy. Święta i zbawienna nauka wiary chrześcijańskiej dążącemu do wiecznej uszczęśliwionego widzenia ojczyzny podróżnemu człowiekowi podana znakomicie wszystkim Szkoły Poetyki alumnom w Akademickiej Tar[nowskiej] Kol[onii] roku Pańskiego 1761 dnia 31 października ogłoszona". (Tytuł łac. na k. 137v).

Inc.: $k$. 139: „Własne na śmierć lekarstwo sposób do zbarwienia $\mathrm{X}$ częstą myślą będziemy, nie moizemy zbłądzićc", k. 167.

3. k. 169-178. ,Maximum in minimo seu amplissimum totius Poloniae regnum una cum suis Palatinatibus, Ducatibus, Capitaneatibus, spiritualibus, statibus, montibus, et fluviis principalibus compendioso in opusculo per M. Stanislaum Michaelem Wątorski philosophiae doctorem scholae poeseos professorem geographica penna circumscriptum. Iam vero curiositatis studiose causa diligentibus Scholae Poeseos alumnis praesertim mihi Michaeli Urbański Scholae Poeseos alumno porrectum anno Domini 1762 die 7 mensis septembris".

Inc.: $\mathrm{k}, 171$ : „Lubo wprawdzie o waszym prezydencie $\mathrm{X} 4$ posłów obiera na sejm", k. 178.

4. k. 179-199. "Gynaeceum fatidicarum Sibillarum spirantium divino enthusiasmo viragiribus in bicolli auguris Apollinis pindo vivis prophetiarum coloribus delineatum. Iam autem Divi Antonii Patavini magni thaumaturgi ad sacerrimam ecclesiae tam PP. Bernardinorum iconem patroni poeticis metris illustratum. Per Stanislaum Nichaelem Wątorski in Alma Universitate Cracoviensi philosophiae doctorem. In academicae Tarnoviensi Colonia pro tunc Scholae Poeseos professorem ad observandum orbi specialiter mihi Michaeli Urbański Scholae Poeseos alumno de vetustissimis perennis oblivionis cineribus historica penna noviter reproductum ac quotidiano usus scholastici exercitio erectum ad MIXXIXXII die 25 mensis augusti:

Inc.: k. 180: „Na rozsądnym sławnego Arystotelesa książęcia filozofów X rector ut inde tuum nomen per saecla triumphet", k. 198.

Szkoła: Tarnowska Kolonıa Akademıcka. Profesor: Stanısław Michał Wątorskl ${ }^{13}$. Skryptor: Michał Urbański.

Rękopis składa sıę z 4 części zawıerających ćwıezenia polsko-łacı́́skıe. Tytuły części 1, 3 i 4 wplecione $w$ kolorową winietę o motywach kwiatowo roślinnych, uwieńczonych u szczytu koroną. Kolumna tekstu w podwójnej ramce. Tytuły i podtytuły wypısane majuskuła. $\mathrm{Na} k$. $46 \mathrm{v}$ obraz nieba „bonum mane“. Dedykacja dzieła św. Janow Kantemu wpisana w trójkąt na k. 135v. W kątach małe koła $z$ napisami: w kole górnym: „Hoc opus finitum est“, w dolnym lewym: „A. D. 1762“, w dolnym prawym: „Die 16 mensis 1ulii". Data 1762 powtórzona na k. 166v i 167. Motyw koła $\mathrm{z}$ dedykacją św. Antoniemu z Padwy na k. 1.93v. Na k. $191 \mathrm{v}$ tarcza zegara, w dole głowa św. Antoniego $w$ aureoli. Ponad aureolą druga $z$ na-

138 Estr. XXXII 258; Jocher nr 1570; J, Le n 1 e k, jw. s. 400 . 
pisem: „Sol es o S. Antoni“. Każda litera drugiej aureoli rozpoczyna zdanie wyprowadzone do cyfry godziny $\mathrm{w}$ górnym otoku. W ten sposób 12 wersetów tworzy hymn pochwalny ku czci świętego.

Składkı: 50 binıonów.

Filıgrany: mężczyzna $\mathrm{z}$ kobietą, w środku motyw roślınny. Obydwoje z rękami wyciągnıętymi. Kapelusz mężczyzny rokokowy z pawımi pióramı, k. 1, 2. Inicjały A P, k. 15. Krzyż z dwoma ramionami, k. 22. Jednorożec w biegu, k. 17, 18.

Oprawa w płsk. cielęcy, barwiony na cıemno, obciągnięty papierem czerpanym, barwıonym na brazzowo. Szycie na 2 sznurki.

Proweniencja: 1. „Ex libris Michaelis Urbański, mpp". k. 1.

2. Biblioteka OO. Kapucynów w Sędziszowtie.

S 51. Eac., pol. 1771. $16.5 \times 10.5 \mathrm{~cm}$. K. 146. Opr. plsk. wsp.

„Institutio de arte rhetorica seu praecepta solutae eloquentiae, eorumque exempla complectens ingenuae iuventuti Scholas Pias frequentanti. Tradita Podolini anno MDCCLXXI. K. I.."

Inc.: k. 2: „Instructio I. Praeludia quo ad eloquentiam $\mathrm{X}$ utilitate cum tuga claris minime", k. 146.

Szkoła: Kolegium pijarów w Podolińcu. Skryptor: K. L.

Reklamanty. Paginacja oryginalna: nlb. 2, 87, pozostałe nlb. numeracja kontynuowana ołówk1em s. 288. Karty niezapisane: $1 \mathrm{v}, 45 \mathrm{v}$. Tytuły wypisane pismem $\mathrm{w}$ forme liter drukowanych. Blok rękopisu oddzielony od oprawy. Składki: 37 bınıonów.

Filıgrany: fragment filigranu niezıdentyfikowanego w górnej części karty.

Oprawa w płsk. cielęcy, zabarwiony na ciemno, obciąnıęta papierem czerpanym, barwionym na brązowo.

Proweniencja: $1 . \mathrm{K}$. L.

2. Bibliateka OO. Kapucynów w Sędziszowie.

S 52. Eac., pol. 1791. $18.5 \times 12.5 \mathrm{~cm}$. Opr. sk. wsp.

,Thesaurus varia erudita, utilia ac iucunda in se continens per P. F. Damasum a Pacerzyce Capucinum p.t. philosophiae, theologiaeque lectorem et contionatorem conscriptus. Rosiampoli inchoatus die 20 februarii. QVot DaMaso InsVnt et qVot M Continet annos VIVIto tot LVstrIs In orbe Pater".

Inc.: $\mathrm{k} .1 \mathrm{v}$ : „Dulcem appellat poeta memoriam operum $\mathrm{X}$ universalis clare dificillimas resolvens quaestiones...", k. 156v.

Treść: k. 1v-48v: przemówıenia różne, $\mathrm{z}$ okazjı rozpoczęcıa studium filozofii w Rozjampolu w r. 1791, dysput teologicznych w Warszawie, zakończenıa studium filozofii i teologii, powıtanie o. Abdona, komisarza generalnego $\mathrm{w}$ Konstantynowie 1779 r., $\mathrm{z}$ racji imienin gwardiana itd. K. 49-63: „Apparatus epistolarum, ex Puteano Erico. Artificia varıa ex P. Odilone Schreger Bened."; wiersze, list Wacława Stehlika z Pacerzyc z dnia 3 maja 1777 r., "cantilenae, apophtegmata“. K. 64-120: "Casus morales practici“, „Summula totius theologiae speculativae Josephi Antonii Caesaremontani ex Provincıa Alsatiae ter provincıalis". K. 121-157: „Concilii 
Trıdenti sessiones“, „Memoriale fundationum in Polonıa Capucinorum", "Genealogia temporalis Damasi Stehlik", "Summula theologiae moralis", "De Paschate cyclo, Epactisque“, różne zapiski.

Do tytułu dodano później uzupełnienie: ,ita cecınit. Platelr Benedictus guardianus Cracoviensis pro die 11 Xbrı 1807. Dulce est meminisse laborum". $\mathrm{Na}$ marginesie zaznaczono poprawkę: ++ „d est lustrae“, którą należy umieścıć po „Insunt“. Paginacja orygınalna: 314. Na marginesach liczne glosy 1 numery paragrafów. Kolumny tekstowe w podwójnej ramce. W tytule chronostych. Wyklejki zapısane.

Składki: 20. Binıon 1. Pozostałe kwatemiony.

Filigrany: tarcza herbowa $\mathrm{z}$ koroną i inicjałamı M I, k. 11, 18, 29.

Oprawa półtwarda $\mathrm{w}$ sk. na cienkiej tekturze. Sk. barwıona, bardzo pomarszczona z przebijającym kolorem zielonym i brązowym. Grzbiet czarnỳ. Szycie na 3 sznurki. Brzegi kolorowe czerwone.

Proweniencja: 1. O. Damazy Stehlik, Czech.

2. O. Benedykt Kulesza, gwardian kapucynów krakowskich.

3. Biblioteka OO. Kapucynów w Sędziszowie.

\section{WYKAZY POMOCNICZE}

Indeksy odnoszą się wyłącznie do rękopısów, przy czym sygnatura bez poprzedzającej litery oznacza pozycje z Biblioteki OO. Kapucynów w Krakow1e. Opısy filıgranów nie zostały objęte indeksem osób I miejscowości. Zakonników kapucyńskıch umıeszczono pod hasłamı imıennymi, ale w miare możnoścı dano odsyłacze do nazwisk. Imına autorów obcych spolszczono.

\section{INDEKS PRZEDIMIOTOWY}

Ascetyczna i mistyozna teologia, $82-95, K 10-K$ 11, R 32-R 33, S 34-S 37.

Biblisityka, 13 cz, 4,18 cz. $4,96-97, \mathrm{R} 34-\mathrm{R} 35, \mathrm{~S} 38-\mathrm{S} 41$.

Dogmatyczna teologia, $1-25,39-44, \mathrm{~K} 1-\mathrm{K} 2, \mathrm{R} 1-\mathrm{R} 7, \mathrm{~S} 1-\mathrm{S} 7, \mathrm{~S} 39, \mathrm{~S} 52$.

Dydaktylka i pedagogika, 149 .

Farmakopea, 170, K 21, R 44 .

Filozofia scholastyczma, 109-138, K 13-K $16, \mathrm{~K} 17 \mathrm{cz} .2$, R $38-\mathrm{R} \quad 41, \mathrm{~S} 44-\mathrm{S} 47$.

Historia Kościoła, 98-106, K 12, R 11, S 42-S 43, S 52 .

Historia Polski, 141, 142, 143, 144, 145, 146, 147 cz. 2.

Historia powsizechnia, $139,140$.

Homiletyka, 57-62, K 5, R 11, R 19-R 22, 氵 17-S 27, S 39.

Językoznawstwo, $150-151$.

Katechetyka, 63-68, 91 (pod koniec), K 6, R 23-R 25, S 44.

Literatura pięknia, $163-169$, K. 20.

Liturgika, $69-72, \mathrm{~K} 7-\mathrm{K} 8, \mathrm{R} 26-\mathrm{R} 29, \mathrm{~S} 28-\mathrm{S} 32$.

Matematykia, $114 \mathrm{cz} .3$.

Medycyna, $170, \mathrm{~K} 21-\mathrm{K} 22, \mathrm{P}, 44-\mathrm{R} 45$.

Modlitewniki, 73-81, 168, K $7, \mathrm{R} 29-\mathrm{R} 31, \mathrm{~S} 33$.

Moralna teologia, $9 \mathrm{cz} .8$ i $9,13 \mathrm{cz} .5,26-56,62, \mathrm{~K} 3-\mathrm{K}$ 4, R 8-R 17, S 8-S 14, S 52.

Nauka o zegarach sionecznych, $114 \mathrm{cz} .4$.

Prastoralna teologia, R 18, S 15-S 16 .

Pedagogika zob. dyidaktyka.

Poetyka zob. retoryka.

Poezje, 166-169, K 20.

Prawo kanoniczne, 9 cz. 5 i 7, 107-108, R 36-R 37 . 
Prawo świeckie, $147 \mathrm{cz} .1$ i $3,148, \mathrm{R} 11, \mathrm{R} 42$.

Reguła św. Franciszka, R 36, R 37 .

Retoryka i poetyka, 152-162, K 17-K 19, R 43, S 48-S 51.

Różne zapiski, K 22, S 52.

Rubryki brewiarzowe i mszalne, K 8, S 25.

Rytuały, 69-71, S 28.

Spiewniki religijne, $K 9, R 31$.

Tragedila, 163.

Tragikomedia, 165.

Wychowanie fizyczne zob. dydalktyka i pedagogika.

Wychowanie moralne zob. dydaktyka i pedagogika.

Złate myśli, 164.

\section{INDEIKS OSÓB I MIEJSCOWOS̃CI}

Abdon kapucyin, S 52.

Achacy $z$ Pragi kapucyn, 29.

Adolf de Dalenborg benedyktyn, R 5 .

Aegidius zob. Sixta Idzi.

Albert jezuilta, 26.

Albert Wiellki św., 113.

Albricht Brunion kapucyn, 40.

Aleksander VII papież, 9.

Aleksander Wielki, S 18.

Alfons de Liguori św., 95.

Alzacka prowincja kapucynów, S 52.

Ambroży św., 164.

Antoine Pawe

Antoniln ze Żdżanne zoỏ. Przedwojewski Antomin.

Antoni Padewski św., S 50.

Antwerpia, $\mathbf{R} 45$.

Argentina zob. Strassburg.

Arystoteles, 111, 113, 114, 118, 119, 121, $\mathrm{K} 17$, S 50.

August II, krói polski, 99.

August III, król polski, 99.

A.ugustianie, klasztor sw. Katarzyny w Krakowie, R 1, R 2, R 8, S 27 .

Augustyn św., R 1, R 2, S 42.

Austria, 135.

Awedyk Konstanty jezuita, 122.

Azor, 9.

B. D. J. K., 77.

Balsam Kasper jezuita, 118.

Baxanów, R 24.

Barnaba kapucyn, 14.

Bartolomici, 29.

Bartolt Erazm augustianin, R 1, R 2, R 8 .

Barszczewski Ksawery kapucyn, S 27.

Batowski Aleksianider, 141.

Bawarska prowincja kapucynów, 90

Baworów, S 26.

Eelgia, 106.

Bełżec, S 48.

Bełżecki Ignacy jezuita, 121.

Benedykt XIV papież, R 17.

Beniamin zoib. Szymansiki Beniamin.

Benwenuty Moravo Policensis kapucyn, $\mathrm{K} 3, \mathrm{~K} 14$.
Bergamo, 90.

Bernard bł. R 28.

Bernard z Bolonii kapucyn, 40 .

Bernardyni - Lwów, S. 40.

- Tarnów, S 50.

Bernardynki - Kraków, S 24.

- Wilno, 98.

Biała, 72.

Biakas Jan ks., 57.

Biecz, S 50.

Bielenin Józef ks., R 25.

Bielicki Kanty jezuita, 9.

Bnin, 157.

Boczarski Andrzej ks., R 6, R 7 .

Bogusz, K 6.

Bohemia zob. Czechy.

Bolechowice, S 24.

Bonifacy IX papież, 105.

Böchner kapucyn, 119.

Brescja, prowinicja kapucynów, 90.

Brinckmann Angelin rekolektyn, $\mathrm{R} 5$.

Brodowsikli Aleksander jezuita, 15, 16 , 17,18

Brodzki Łodzia Ignacy, S 18.

Brassman Jian Franciszek, R 36 .

Erzeski Ksawery jezuita, 114.

Brzostorwski Bończa Joachim Antoni ks., 73.

Brzuchowski Samuel kapucyn, 138.

Buczyński Wincenty jezuita, $R 41$.

Busenbaum Herman jezuita, R 38 .

Bystrzonowski Józef jezuita, S 11.

Caietanus Maria a Bergamo zob. Kajetan Maria z Bergamo.

Calissium zob. Kalisz.

Cantallicio, 71, R 16.

Carl Romediusz kapucyn, K 2.

Caulerius Simon zob. Caulier Simon.

Caulier Simon, 155.

Charzowice, S 24.

Chenczel Prymian kapucyn, 127.

Chocim, K 18.

Chrast (?) Jam Stanislaw, 63

Cieszyniski ks., S 24 .

Claudius ab Antonio Padovano zob. Krasnodebski Klaudiusz. 
Constantinus Varsaviensis zob. Meliński Konstanty.

Constantius Crasnostaviensis zob. Konstanty z Krasnegostawu.

C[onstantius] kapucyn, R 26.

Corbeletti, 163.

Cornarius Venetus Ludwik, R 45.

Cybulski Antoni ks., $R 43$.

Cycero, S 14, S 18.

Cygler Kajetan kapucyn, 84, R 11, R 12, S 35.

Czechy, 99.

Czeczott Mikołaj kapucyn, R 45.

Czescy kapucyni, 11, 135, S 26.

Czeska prowincja kapucynów, 13, 29.

Czesław kapucyn, S 30.

D. B. ks., 87 .

Dailenborg Adolf de, zob. Adolf de Dalenborg.

Dalmacja, R 11.

Damazy zob. Stehlik Damazy.

Danecki Franciszek, S 18.

Dembiński Stanisław Kostka, 157.

Demibowski Edward, 141.

Dembowski Leon, 141.

Demisterius jezuita, 26.

Dębski Jenzy jezuita, S $10^{3}$.

Dobrawski Andrzej kapucyn, 75, K 20.

Doctor Angelicus zob. Tomasz z Akwinu Św.

Dolińsiki Leon kapucyn, 49, S 2-S 6 .

Dominik kapucyn, 13, 14.

Dominikanie - Lwów', 48.

- Kollegium w Eucku, 112.

Donner Hieronim, R 36 .

Dorożyński Adam, 162.

Drabek Aleksander kapucyn, R 10 .

Drabowick Makary kapucyn, 84.

Drajewicz, S 30.

Drużbicki Kasper jezuita, R 27.

Dubaszewski Wacław kapucyn, 29.

Duns Szkrot Jan, 13, 14, 21, 32, 37, 120 , $123,124,125,126,127,128, \mathrm{~K} 3, \mathrm{~K} 14$, $\mathrm{R} 13, \mathrm{R} 14, \mathrm{R} 15, \mathrm{R} 39, \mathrm{R} 40$.

Dzieduszycki, 141.

Eisentraut Piotr jezuita, 65.

Flzeariusz Porzicensis kapucyn, 13, 14.

Emanuel kapucyn, 29.

Eschius Mikołaj, 83.

Ezechiel kapucyn, 13, 14.

Europa, 145.

F L., 95 .

Fabiani ks., S 27.

Federowicz Maciej Stanisław prof., 154, 155.

Federus Jan Jerzy Henryk, 135.

Felicissym Neorodiensis (z N. Rudy), 32 .

Felicissym z Würzburga zob. Hörlein Jan Tobiasz Roch.

Felicjanki - Kraków, S 24.
F'eliks kapucyn, 49.

Feliks z Cantalicio św., 71.

F'erdynanda Akademia w Pradze, 116.

Fierich Edward prof. U.J., 148.

Filkiewicz Wojciech jezuita, 131, 132.

Firminian Palatinus kapucyn, K 3, K 14.

Fiume, R 11.

Flumen zoib. Fiume.

Fortunatus January prof., 5, 6.

Franciszek z Warszawy zob. Laziosi

Franciszek św., $13,40,41,42,43,47,56$, $90,94,120,133,136, \mathrm{R} 5, \mathrm{R} 36, \mathrm{R} 37$, $\mathrm{S} 21, \mathrm{~S} 23$.

Franciszkanie konwentualni - Kalisz, R 39 .

- Ratyzbona, 136.

F'ranciszkanki zob. Klaryski.

Francja, 106.

Franzelin Jan jezuita, S 2-S 6 .

Fulda (diecezja), R 5 .

Furgalski Kajetan kapucyn, 13, 14.

Galia zob. Francja.

Galicjia, 106, 165.

Galicyjska prowincja kapucynów, 141, S 24, S 25, S 26, S 27.

Gaume Jan ks., 95.

Gaworski Jan Nepomucen, R 38.

Gdańsk, 146.

Gdów, 141.

Gerwazy Brisacensis (z Breisbach) kapucyn, $R$ 11, R 12.

Giattinif Panormitanus Jan Chrzciciel jezuita, 163.

Głogów, S 34.

Głowacki, 166.

Gniezno, 157.

Gocel Ludwik, 31.

Gonzales, 9.

Gorlicki Zenon kapueyn, wymieniony prawie we wszystkich opisach rękopisów kllasztoru krakow'skiego, S 42.

Goryl Michał ks., K 12.

Gorzyce, S 30.

Grabiński Kazimierz jezuita, K 1, K 15.

Gradziński Dionizy jezuita, 7.

Grappini Hieronim jezuita, 115.

Grekka Herakliusz kapucyn, S 12.

Grodno, 159.

Grzegorz św., 5.

Grygielski Klemens (Klementyn) kapucyn, 29, 38.

Gutkowski Jan jezuita, 107.

Hański Michał ks., R 43.

Henckel Lazarus von Donnersmarck Graff, R 44.

Herkulan kapucyn, S 27.

Hieronim św. S 20.

Hinal Benedykt reformat, S 28.

Hoffmehr Gotfryd, R 44 .

Holtz Walenty z Reszla kapucyn, 29.

Honoriusz III papież, R 36 . 
Hòrlein Jan Tobiasz Roch kapucyn, 119

Fiudelka Protazy kapucyn, 33.

Hugolin Ziatecensis ( $z$ Zatec) kapucyn, 32.

Hungaria zob. Węgry.

Ingelström gen., 141.

Innocenty $\mathrm{X}$ papież, 9.

Iwasiówka.Aleksander, s 7.

Izajasz kapucyn, 14.

J. L. K., 78 .

Jagiełło król polski, R 10.

Jalkubowicz Romuald kapucyn, 30.

Jakubowski Józef ks., 1!8, S 49.

Jan III Sobieski, król polski, 91, K 18.

Jan Chrzciciel św., 157.

Jan de Matha św., 157.

Jan de Sacro Bosco, 113.

Jan Ewangelista Św., R 19.

Jan Kanty św., 109, 113, 157, S 50.

Janikowski Krzysztof Stanisław, 146.

Jarrosław, R 31.

Jedlicze, 57.

Jeremiasz kapucyn, 14.

Jezuilci - Akademia we Lwowie, 18, 122.

- Akademia w Wilnie, $\mathrm{S} 39$.

- Collegrum Romanum, 1, 2, 3, 163, S 2-S 6.

- Gimnazjum w Tarnopolu, R 41,

- Kolegium w Kaliszu, $\mathrm{S} 37$.

- Kollegium w Krakkowie, 24, 25, R 27, S 42.

- Kolegium $w$ Krasmymstawie, 129, 130, 131, 132.

- Kolegium w Krośnie, 163, K 1, K 4, $\mathrm{K} 15, \mathrm{~K} 17, \mathrm{~K} 19$.

- Kolegium we Lwowie, 7, 8, 9, 15, 16, $17,107,115, \mathrm{~S} 10$.

- Kolegium w Lublinie, 114.

- Kolegium w Eucku, 117.

- Kolegium w Poznaniu, R 27, S 38.

- Kolegium w Pułtusku, 152.

- Kolegium w Sandomierzu, S 11.

- Kollegium w Słonimie, 160.

- Kolegium w Stanisławowie, 118, 121.

- Seminarium Romanum, 163

Jihlava, 34.

Joachim kiapucyn, R 11.

Jodłowa, $S 50$.

Józef Antoni Caesaremontanus ( $\mathrm{z}$ Kaysersberg) kapucyn, $40,41,42,46,47$, $56, \mathrm{~S} 52$.

Józef II cesarz, 105

Juliusz Cezar, S 18.

Jurecki pleban, K 17.

Jurewicze, 75.

Jurkowski A., 116.

Justyn ze Lwowa zob. Son Justyn.

K. L., S 51 .

Kahles Mikołaj, 119.

Kajetan zob. Furgalski Kajetan.
Kajetan z Bergamo kapucyn, 90.

Kalisz, S 37.

- franciszkanie,

- jezuici,

Kamieński Antoni, 144.

Kamiński Wojeiech, ks., 59.

Kania A., 149.

Kapucyni - Kraków, 1-170, K 10, S 2, $\mathrm{S} 7, \mathrm{~S} 44, \mathrm{~S} 52$.

- Krosno, 85, 165, K 1-K 22, R 22, S 19.

- Kutkorz, 29.

- Lubartów, 84, K 10, R 5, R 10, S 36.

- Lublin, 29, 36, 61, 123, R 10, S 26.

- Lwów, 29, 30, 31, 127, R 13.

- Eomża, S 25.

- Mariampol, 18, 118, 122, 147, K 10, S 49.

- Nowe Miasto, S 27.

- Olesko, $9,10,12,15,16,17,18,20$, $21,29,33,35,36,42,46,48,60,75$, $88,90,107,114,115,117,118,122,147$, 153, 159, K 20, R 11, R 12, R 13, R 14, $\mathrm{R} 15$.

- Ositróg, 31.

- Praga - Hradozyn, 29, 32, K 3, R 26.

- Rozjampol (Uściług), 124, 128, K 5 , $\mathrm{R} 40, \mathrm{~S} 52$.

- Rozwardów, R 1-R 45.

- Rywałd, S 26.

- Sędziszów, 38, S 1-S 52.

-- Stary Konstantynów, R 16, S 52.

- Uściług zob. Rozjampol.

- Warszawa, 13, 14, 29, 38, 61, 164, K 7, S 25, S 27, S 52 .

- Winnica, 40, 41, 42 .

- Włodzimierz Wołyński, S 24.

- Wrocław, 32.

- Zaukroczym, 38, S 46.

- Zatec, K 3.

- Znojmo, K 3, K 14, R 26.

Karmelici trzewiczkow1 - Kraków, S 24.

JKarola Ferdynandja Akademia w Pradze, 116.

Karpowski Jan jezuita, 117.

Katana Leonard kapucyn, S 21.

Kraszewicz Wojciech, S 50.

Kazimierz św., 157.

Kellar Damazy kapucyn, 25.

Kielarski Franciszek, S 48.

Kielarski Franciszek Michał 153.

Fielce, 27, 152.

Kielnar Julian kapucyn, 90.

Kijliński, 166.

Kinner Wilhelm Baro de Scharffenstein. 13.

Klaryski - Kraków, S 24.

Klemens V papież, R 37 .

Klimek Wiktor kapucyn, S 2.

Klimkiewicz Paweł kapucyn, R 12.

Kla... Franciszek, 161.

Kobielski Józef jezuita, 7.

Kachanowski Marcin Stanisław, ks., 57. 
Kochanowski Michał 141.

Kojsiewıez Ferdynand prof. U.J., 144.

Kollątaj Hugo ks., 144.

Konieczko Antoni Michal ks., K 1, K 4, K 15 , K 19.

Konrad zob. Resch Konrad.

Konstanty $\mathrm{z}$ Krasnegostawu, $\mathrm{R}$ 1, $\mathrm{R}$ 2, R 8.

Konstanty ze Swidnicy kapucyn, 13, 29.

Konstanty wielki książę, 142.

Korzeniowski Alojzy kapucyn, 130, 131, 132.

Korzeniowski Antoni jezuita zob. Korzeniowski Alojzy.

Kossakowski bp, 141.

Kossakowskich familia, 144.

Fościuszko Tadeusz, 166.

Kotlarski Zygmunt kapucyn, 36 .

Kozaki, R 10.

Kozerska Helena, 37.

I ozicki Michal jezuita, K 4.

Kozieradzka Kamila, 168.

Kozłowski Stanisław jezuita, S 11.

Kralków, 38, 82, S 44.

- augustianie,

- bernardyni,

- felicjanki,

- franciszkanki (klaryski),

- jezuici,

- kapucyni,

- karmelici,

- pijarzy,

- reformaci,

- kościoły: św. Anny, 109.

- - św. Barbary, S 24, S 42.

- - cmentarny, S 24.

- - św. Floriana, 5, 6, 156, 157, S 44.

- - na Zwierzyńcu, S 26.

-. szkoły: Akademia Krakowska, 109, $110,111,113,157, \mathrm{~S} 44$.

- - Liceum św. Anny, 144.

-.. - Seminarium nauczycielskie, $R 25$.

- - Szkoły Nowodworskie, 154, 155, $156,157$.

- - Uniwersytet Jagielloński, 148, 150 .

Kralizek Zygmunt, K 21.

Krasnodębski Klaudiusz pijar, $\mathrm{R} 43, \mathrm{~S} 48$.

Krasnystaw, R 1, R 2, R 8 .

- jezuici,

Krawczycki Benedykt ks., S 30 .

Krawczyński Tadeusz kapucyn, 43, 44, $133, \mathrm{~K} 11$.

Kroczyński Michał ks., R 23.

Krohliński Pawel, 15, 17.

Krosno, 57.

- jezuici,

- kapucyni,

- szkola cesarskiso król., K 16.

Królestwo Polskie, 145.

Krtowas (?) Ludwik dominilkanin, 112.

Krupa, R 10.

Kruszyński Michał, 99.

Kruszyński Stanisław, 57, 99.
Krzạnowsklki Michal Antoni ks. prof. Akad. Krak. 5, 6, 154, 155, 156, 157, S 44.

Krzysikiewicz (Krzysik) Józef kapucyn, $46, \mathrm{R} \mathrm{18,} \mathrm{R} \mathrm{35,} \mathrm{R} \mathrm{41,} \mathrm{S} \mathrm{40,} \mathrm{S} 43$.

Kwietmiewicz Walenty ks., R 30 .

Fubalski Aidan kapucyn, S 12 .

Kuczera Amand dsapucy,n, R 10, R 17. S 19.

Kulesza Benedykt kapucyn, S 52.

Kumporth Piotr kapucyn, K 5.

Kuzel Firminian kapucyn, 85, 106.

Kuzerski Andrzej jezuita, 114.

L. K. S. E., 26

Ladislaus Prissinensis zob. Puciata Władysiaw.

Ianckorona, 157.

Langer Antoni jezuita, 24.

Laziosi Franciszek kapucyin, K 7 .

Leander zob. Lendzian Leander.

Ledil Oliweriusz kapucyn, K 22.

Lemański Jan jezuita, K 19.

Lendzian Leander kapucyn. 49.

Irentz Liborıusz kapucyn, 13, 14.

Leon z Krakiowa zob. Dolinski Leon.

Lessius Leonard jezuita, R 45.

Lewandowski Dezyderiusz kapucyn, 69.

Leżbicki Kalzımierz Domınik, 158.

Liboriusz Graslicensis ( $z$ Grasl itz) kapucyn, 29.

Liboriusz Königsfeldensis (z Königsfelde) kapucyn, zob. Lentz L.

Litomierzyce, 134.

Litomislium zob. Litomierzyce.

Lobkowitz ksiaze, K 3 .

Irorencowicz Aleksander jezuita, R 27.

Lotaryngia, 29.

Lubartów zob, kapucyni.

Lublin zob. jezuici.

- kapucyni,

- Kościół św. Ducha, S 23, S 24.

Lublin, 61.

Lubomirscy, K 18, R 43,

I ubostronie, 146.

Lubowiedrki Jacek dominikanin, 112.

Luceoria zob. Łuck.

Luciusz Iglaviensis ( $\mathrm{z}$ Jihlavy) zob. Velle Lucjusz.

Ludovicus Cornarius Venetus zob. Cornarius Venetus Ludwik.

Ludwik franciszkanin, $R 39$.

Lugo, 9.

Luneville, 29.

Lwów, 30, R 36, S 7, S 40 .

- jezuici,

- kapucyni,

- Studium generalne dla zakonnilków, 48, S 7, R 18.

- Uniwersytet, S 7.

Labuda J. ks., S 16.

Eagiewniki, S 18. 
Łaszcz Alekslander Michał, S 48.

Łaszczów, S 48.

Łączyński Andrzej jezuita, 8, 9, 107.

Eeki, R 43.

Eomża zob. kapucyni.

Eopacki Remigiusz ks., 57.

Eowicz, 91.

Łubieński Kazimierz bp, 1, 2, 3, 27, 109, $110,111$.

Euck zob. dominikanie.

— jezuici.

花夜i Jan jezuita, 17, 18.

Łuków zob. pijar'zy.

Eyczko Jędrzej ks., R 21.

Ma. Len., 91.

Viadaliński, 166.

Mady Franek, S 24.

Vlaciej pijar, $\mathbf{S} 48$.

Magierów, S 20.

Nalechów, S 8.

Mialinowski Lucjan prof. UJ, 150.

Małachowski Julian, 166.

Maniecki Pitus kapucyn, 38.

Mańlkowski Ubald kapucyn, S 30.

Marcelinus, 101.

Marcin kapucyn, 13, 14.

Marcin św., 136.

Mareti Jan, R 45.

Maria Teresa cesarzowa, 13.

Mariampol zob. kapucyni.

Martinez Mikołaj jezuita, 1, 2, 3.

Martusiewicz Józef Kazimiérz ks., S 15.

Maryna Aleksy bernardyn, 98.

Materna Ksawery kapucyn, R 22.

Mateusz kapucyn, 14.

Miathias zob. Maciej pijar.

VIathuszewicz Anırzej Franciszek ks., S 18.

Maurus Sylwester jezuita, 2, 3 .

Meliński Konstantyn kapucyn, 29.

Meschler Maurycy jezuita, K 12.

Michal kapucyn, 56, S 23, S 24, S 26.

Michalski Jan ks. prof. Akad. Krak., 109.

Michna, R 6.

IVikolaj III papiez, R 37.

Misjonarze - Włocławek, 10, 12.

Modlnifca Wielka, 62

Mojzesz, 101, S 20.

Mokronowski, 166.

Monachium, 90.

Montani Jan jezuita, R 27.

Moridoni jezuita, 29.

Mioszyński Ferdynand, 141.

Nadassy Jan jezuita, 26.

Neapol - Seminarium Arcybiskupie, 5,6 .

Nicollaus Siennensis zob. Okólski Mikołaj.

Niemcy, 140.

Niemojewrski Józef gen., 142.

Nowakowski Józef ks., 72.
Nowakowski Wacław kapucyn, 72, 98, $141,142,143,146$.

Nowe Miasto zob. kapucyni.

Nowy Sącz, 57, 99.

Nowiszewski Tomasz kapucyn, R 19, R 20.

O. J. L. K., 78.

Gdorowski Innocenty kapucyn, S 13.

Odrzykoń, s 27.

Odrzywolski Ignacy, jezuita, 18.

Okólski Mikołaj kuapucyn, 29.

Olesko zob. kapucyni.

Olechowicz Józef jezuita, K 17.

Olęcki Andrzej, 152.

Olicensis Akademia zob. Olyka Akademia.

Olyka - Akademia, 158.

Opaliński Stanisław, 157.

Opatów, R 43.

Orichovius Stanislaus zob. Orzechowski Stanisław.

Orłowsiki Michał jezuita, 15, 16.

Orzechowski Stanisław, 146.

Ostański Benedykt Józef ks., K 19.

Osternieder Herman franciszkanin, 136.

Ostrowski jezuita (?), K 17.

Ostróg zob. kapucyni.

Owidiusz poeta, $\mathrm{S} 18$.

F. C. F, R 26.

Pacerzyce, S 52.

Paszkiewicz Jan Chrzciciel, ks., K 8.

Patlia Wojciech kapucyn, 23, 136.

Paulanus prof., 29.

Paulini - Krakków, S 26.

Pawel św., 11, R 6, R 43 .

Pawłowsiki Daniel jezuita, S 37 .

Peniżek Kolumban kapucyn, K 10.

Pezzara Franciszek, 56.

Pezzara Mikołaj, 56.

Pęski Adlam, S 38, S 39.

Pieskowa Skała, 157.

Pijarzy, S 45.

- Kolegium w Krakowie, 143.

- Kolegium w Eukawie, 159.

- Kolegium w Podolińcu, S 51.

- Kolegium w Rzeszowie, 69, K 18, R 43 .

- Kolegium w Waręzu, 153, S 48.

Pilawski Ignacy jezuita, K 4 .

Pilzno, R 43.

Piotrovius Lucas zob. Piotrowski Lukasz.

Piotrowski Łukasz, S 50.

Pius VI papież, 106 .

Plantiniana officina, R 45.

Pniów, S 27.

Poczajów, S 33.

Podfilipski Feliks kapucyn, R 16.

Podhorce, 76.

Podhorodecki Michal, S 49.

Podoliniec zoib. pijarzy.

Podoska z Junoszów Katarzyna, S 26. 
Pokucie, K 10.

Polkowski Ignacy ks., 146.

Polska, 13, 134, 138, 146, 153, 157, S 52.

Polska kustodia kapucynów, 14.

Polska prowincja jezuitów, $R 27$.

Folska prowincja kapucynów, 43, 62, S 24, S 25, S 26, S 27.

Połoński Bazyli ks., 72.

Porfiriusz, 157.

Potoccy, R 11.

Potocki Włoidzimierz, 166.

Poznań, 157.

- jezuici,

Praga (Czechy), 116, K 3.

- kapucyni,

Frajer K., S 7 .

Prosper Neostadiensis (z Neustadt Prudnik) kapucyn, 32.

Protazy Pasquicensis (a Pasqua, z Pyskowic) zob. Hudelka Protazy.

Pruski Jan Nepomucen ks., K 16.

Pruszyński, 148.

Przedwojewski Antonin kapucyn, 35, K 14.

Przemyśl, R 6, R 7, S 16.

Fuciata Wladysław kapucyn, 36.

Puitusk zob. jezuici.

Futeanus Eryk, S 52.

Raczek, R 6.

Raszyn, 142.

Ratyzbona, 136.

Fieformaci - Kraków, S 24, S 28.

Reginaldus, 9.

Reiffenstuel Anaklet, 38, R 16.

Rejtan, 166 .

Rembecki Józef prof. UJ, 113.

Remigiusz z Rychnowa kapucyn, 30, 31.

Remigirani Jian, S 9.

Reńska prowincja kapucynów, 119.

Resch Konrad kapucyn, 42.

Ressovia zob. Rzeszów.

Romediusz zob. Carl Romediusz.

Romualdus Siekaczynensis zob. Siekaczyński Romualid.

Rosja, 144.

Rozjampol zob. kapucyni.

Rozwadów zoib. kapucyni.

Rozwadów parafia, R 19, R 20, R 43 .

Rożek (?) Władysław, 79.

Rzeszów zob. pijarzy.

Rzewuiski Wacław, 75.

Rzym, 1, 2, 3, 40, 163, R 38.

-.. jezuici,

Rychnov, 30 .

Rywałd zob. kapucyni.

S. kapucyn, 65.

Sacro Bosco Jan de zob. Jan de Sacro Bosco.

Sanctus Iglaviensis (z Jihlavy) kapucyn, 34.

Sandomierz zoib. jezuici.

Sankowski Franciszek, 98.
Sawicki Chryzostom jezuita, 115.

Sichemik Franciszek Borgiasz kapucyn, 48.

Schouppe Ksawery jezuita.

Schreger Odilon benedyktyn, S 52.

Scotia zob. Szkocjia.

Scupoli Wawrzyniec teatyn, 89.

Sebastian, 163.

Sebastian kapucyn, 14 .

Ségur Ludwik Gaston bp, R 22.

Sembratowicz Sylwester kard., S 7 .

Senftleben Jan jezuita, 116.

Sędzimir Dominik jezuita, 122.

Sędziszów zob. kapucyni.

Siekaczyński Romuald augustianin, R 1, $R 2, R 8$.

Sieklucki Michał jezuita, R 27.

Siemianowice, $R 44$.

Siemiński Andrzej jezuita, 7, 9, 107.

Sieradz, 157.

Sigismundus Oppoliensis zob. Kotlarski Zygmunt.

Sikorski Szymon kapucyn, 19, 35, 37, 123, 125, 126.

Silesia zob. Sląsk.

Simon a Lipnica zob. Sikorski Szymon.

Simonetti Franciszek jezuita, 114.

Sixta (lub Syxta) Idzi kapucyn, 30.

Skaryszewski bp. 141.

Skiron Idzi kapucyn, 61, 124.

Słabikowski Michał, 64.

Słabniewicz Andrzej jezuita, 129, 130.

Slonim zoib. jezuici.

Słupów, 157.

Smetana Maciej kapucyn, 41.

Sokołowski Jan Kanty, 113.

Solski, R 6.

Son Justyn kapucyn, 29.

Sowiński, 166.

Spada Marian, S 3, S 4, S 6 .

Spira, 105.

Stanisław August Poniatowski, król polski, 99, 141.

Stanisław Leszczyńskii król polski, 29.

Stanisław Szczepanowski św., 157, 164.

Stanisławów, 118, S 49.

- jezuici.

Stary Konstantynów zolb. kapucyni.

Stehlik Damazy kapucyn, 62, K 11, S 24, S 26, S 52 .

Stehlik Waclaw, S 52.

Stephen Paulin kapucyn, 128.

Stokowski Franciszek jezuita, K 19.

Strassburg, 40.

Strzelecki Sylwery, S 26.

Styria - prowincja kapucynów, R 11.

Sucharski Jan Franciszek, 63.

Suworow gen., 141.

Syrowy Wit kapucyn, 124, 128, R 13 , R 14, R 40.

Szczepan św., S 24.

Szczerbiński, R 6.

Szczurowski 'Tymoteusz bazylianin, 72. 
Szarkowski Poncjan kapucyn, 40, 41, 42. Szarliński Wincenty kapucyn, S 30 .

Szembek Jan, 157.

Szkocja, 124, R 40.

Szolidrsk1 Władysław, 157.

Szoldrski Szczepan, 157.

Szopniewski Marcin jezuita, K 17.

Szumowski Filip kapucyn, 43, 66, 67, 68.

Szymański Benlilamin kapucyn, 135, S 23, $\mathrm{S} 25$.

Szyruxid Konstianty jezuita, S 39.

Scislowicz Damazy kapucyn, S 12.

Sląsk, 32.

Slaskia kustodia kapucynów, 32.

Ślizowsiki, 143.

Swirczyński Antoni jezuita, S 10

Tamburinus, 9.

T'arkowski Walenty ks., R 23.

Tarnaw'ski Józef, 73.

Tamopol zob. jezuici.

T'arnów, K 19, S 15, S 50.

- Kolonia Akademicka, K 19, S 50.

Taurinum zob. Turyn.

Tera... ks., S 8.

Terencjan zob. Żychliński Terencjan.

T'erlecki Jan, 121.

Teodul Plagensis (z Plagov?) kapucyn, R 26.

Titz Wacław jezuita, 25.

Tokarz Wachaw prof. UJ, 141, 142, 143.

Tomasz $z$ Akwinu św., 1, 2, 3, 7, 8, 9, $15,16,17,107, \mathrm{~S} 8, \mathrm{~S} 10$.

Tomasiz z Celano, K 7 .

Tomass z Charmes kapucyn, 38.

Tomasz z Kempis, 82, S 37.

Tortowski Hieronim prof. UJ, 113.

Trackie województwo, 98.

Tronowski Rafał kapucyn, 44.

Trydent, 63 .

Trzecieska Katarzyna, S 26.

Tuczany, S 48 .

Tuma Zenon kapucyn, 127.

Turyn, 40.

Turyńska prowincja rekolektów, R 5 .

Tyrmawa - Seminarium Arcybiskupile, 26.

Ungaria zoib. Hungaria.

Uphagen Jan, 146.

Urbański Michał, S 50.

Urbański Stanislaw, K 16.

Uściług zob. kapucyni.

Valentinus Ressoliensis zob. Holtz Walenty.

Velle Lucjusz kapucyin, R 14.

Venceslaus Varsaviensis zob. Dubaszewski Waclaw.

Vetero Constantynovia zob. Stary Konstantynów.
Vincentius a Grodzisko zob. Szarliński Wincenty.

Vötter Jan, 90.

Wadiowski Idzi Stefan prof., 26, 156, 157.

Waręz zob. pijarzy.

Warmia. 128.

Warszawa, 29, 37, 61, 91, 141, 142, S 27.

- kapucyni.

-- Kolegiata św. Jana, 29, 126.

Wątorski Stanisław Michał ks., S 50

Weiss, R 6.

Weluński Wojciech, K 17.

Wenecja, 40, 56.

Weronilka Giuliani św., 80.

Wetzlar (NRF), R 5 .

Weysse Kazimierz ks., 27, 152.

Wegry, 13 .

Wiedeń, 140.

Wielopolski Franciszek, 157.

Wierzbicki Krzysztof jezuita, K 17.

Wieżadlowski ks., K 8 .

Wigandt, 38.

Wilno, 98.

— bernardynki,

-.- jezuici,

- Kościól św. Michała Archanioła, 98.

Winnica zob. kapucyni.

Wirgiliusz poeta, S 18

Wiśniowski Michał, 112.

Władysław św., 157 .

Whoclawek zob. misjonarze.

Whodzimierz Wolyński zob. kapucyni.

Wodzickı, 166.

Wolff Kazimierz ks., S 34.

Wolborius Baltazar jezuita, S 38.

Wołkoński ksiązę, 141.

Woycicki Pawel, S 22.

Wójcikrwski Maciej ks., 108.

Wrockaw zob. kapucyni.

Wróblewski Walenty kapucyn, 19, 37, $126, \mathrm{~K} 2$.

Würzburg, 119.

Zagość - parafia, 57.

Zakroczym zob. kapucyni.

Ĺamojski Andrzej, 141.

Zawadzka Anna, 81.

Zawadzki Filip, 81.

Zawiliński Roman prof. UJ, 150.

Zdarzil Kazımierz kapucyn, S 26.

Zelek Edward kapucyn, S 7.

Zelinka Ananiasz kapucyn, S 35.

Ziattecium zob. Žatec.

Znojmo zob. kapucyni.

Zubowski Pawel jezuita, 160.

Zarnowiecki starasta, 116, 157.

Zarnowieckie starostwo, 141.

Žatec zob. kapucyni.

Zdżanne, K 14.

Zychliński Terencjan kapucyn, 39.

Żywiec, 157. 


\title{
DE CODICUM MANUSCRIPTORUM CATALOGO BIBLIOTHECAE PROVINCIAE CRACOVIENSIS ORDINIS FRATRUM MINORUM CAPUCINORUM
}

\author{
Sum marium
}

Manuscriptorum ab anno 1600—1900 commentatus catalogus 170 ex bibliotheca coenobii Cracoviae, 22 e monasterio Crosnae, 45 e sacris claustris Rosevadoviae, 52 ex eiusdem saeptis Sendisoviae petita exemplaria tenet. Omnium igitur manuscriptorum, e bibliothecis Capucinis provinciae Cracoviensis, sumptorum codicum summa aequat 289 numeros. Qui codices dividi possunt in eos, qui penes scholas et qui citra scholas habebantur. Scholis destinati exstant plurimi et ex variis religiosils scholis oriuntur, suntque igitur pp. Capucinorum, Societais Iesu, Scholarum Piarum, Augustinianorum, congregationis Missionum, ordinisque Praedicatorum. Inter hos manuscriptos sunt quasi legati paene omnium sedium scholarum nostrae civitatıs una cum Academia Cracoviensil, Vilniensi, Leopoliensi atque nonnularum exterarum gentium uti Pragae, Collegii Romani, archiepiscopalis Seminarii Neapoli, studiorum universitatis Virceburgii aliorumque lyceorum. Haec quidem volumina sunt quoddam speculum varietatis hisce temporikus in doctrina schollastica, ad mentem s. Augustini, s. Thomae Aquinatis atque Duns Scoti, tradenda.

Itali Capucini in biblicthecarum collectionibus provinciae Cracoviensis nullum, ad scholam attinens, volumen reliquerunt. Servati sunt tamen codices Capucinorum Bohemorum, qui an. 1738 Capucinorum Itallorum patrocinium in Capucinos Polonos susceperunt. Illorum gratia factum est, ut coenobia Polona an. 1754 ius provinciae adepta sint. Anno 1761 accidit, ut germanae hae provinciae distinctae disiunctaeque sint. Nihilominus in finibus nostrae patriae plures Capucini Bohemi manserunt et in provinciam Polonam, deinde Gallicianam etiam in rebus scholarum multum contulerunt. Inter quos imprimis Remigius Richnoviensis, Zeno Neosedlensis, Elsearius Porzicensis, Constiantius a Suednicio, Vitus Syrowy patres memorandi sunt. Volumina etiam aliorum Bohemorum lectorum, in Polonia operam navantium, in nuncupatis bibliothecis servata sunt.

Parum notum aestimatumque est, quantum Capucini Bohemi in Polonia provincia constituenda valuerint, magısque obscurum est, quid ad Capucinas in Polonia scholas invanidas contulerint. Haec meminisse iuvat, dum consioclati laboris Polonorum Bohemorumque Capucinorum (1738-1963) 225 celebrantur anni.

Cum Iosephus II, Austriacorum imperator coenobia aboleret, codices monasteriorum Blisenae, Leopoli, Mariampoli, Oleseci asservati, aliquot exceptis, perierunt. Manuscriptos Cutecorii superstites, una cum bibliotheca, ultimus eiusdem coenobii praeses an. 1944 dereliquit. F bibliotheca monasterii solummodio codicum elenchus, manu patris Zenonis Gorlicki confectus, salvatus est.

Tum ad philosophiam tum ad theologiam spectantes scholarum codices e colllegiis patrum Societatis Iesu, patrum Scholarum Piarum aliarumque religionum deprompti, planiorem forte pandent viam, ut de gradu ecclesiasticarum disciplinarum, hisce temporibus traditarum, verum iudicium feratur.

Inter codices ad scholas non attinentes iuvat conspicere eos, qui ad campum historiae Poloniae referuntur. In quibus praeter ceteros duos, nr. 141 et 143 ornatos, viri. rerum gestarum periti, Venceslaus Nowakowski, pater et Venceslaus Tokarz, professor, commentati sunt.

Primum inventarium codicum Capucinorum, "Collegio S. Lanrentii Brundisini" Assisii postulante, annis 1930-1934 a Zenone Gorlicki, patre confectum est. Suo 
scripto tantum codices a Capucinis exaratos inseruit. Qui catalogus, ceterum paucis ex fragmentis notus, Polonis in collecionibus non invenitur.

Quotquot sunt Capucinis in bibliothecis provinciae Cracovlensis codices, an. 1961 ex ipsorum bibliothecis exempti, ut serventur magna cura reficiuntur Tencini, qui est locus dioecesis Cracoviensis et peculiari indice recensentur. Cui tutelae perficiendae conclavia ultroque oblatum auxilium, Medardus Parysz, pater, eiusdem paroeciae administrator, praebuit.

In singulorum codicum descriptione facta pars generalis et specialis distinguitur; hac in parte, praeter genuinum titulum, praeter locos, qui incipiunt et explicumt volumina, propriae singularesque notae manuscriptorum, uti argumentum, habitus delineartio, glossae tum in marginibus tum inter lineas positae, sententiae, insicriptiones, signatia tempora, imprimis textus Poloni, signantur. In scholarum codicibus describeridis de industria schola, magistri, vel lectores et scriptores notabantur. Deinde numeratae sunt plicaturae chartarum signataeque paginarum custodes. In referendis in album aquaticis chartarum signis via ratioque descriptionis adhibita est cum eiusmodi signa, an. 1600 supenantia, adhuc commentationibus indigeant. Codicum tegmina dr. Robertus Jahoda Źoltowski catalogo recensuit. Maior vero cura origini codicum eorumque superioribus notis compendiariis tributa est. Annexi auxiliarii census facient, ut tum desidderatae quaestiones tum personae agentes, expeditius detegantur. 